\title{
A SOLIDÃO DA AMÉRICA LATINA NA GRANDE IMPRENSA BRASILEIRA
}

Dissertação apresentada à Área de Concentração de Jornalismo Comparado da Escola de Comunicação e Artes da Universidade de São Paulo, como exigência parcial para obtenção do título de Mestre em Jornalismo no Programa de Ciências da Comunicação, sob a orientação da Profa. Dra. Nancy Nuyen Ali Ramadan.

\section{UNIVERSIDADE DE SÃO PAULO ESCOLA DE COMUNICAÇÃO E ARTES DEPARTAMENTO DE JORNALISMO E EDITORAÇÃO SÃO PAULO 2005}


ALEXANDRE BARBOSA

\title{
A SOLIDÃO DA AMÉRICA LATINA NA GRANDE IMPRENSA BRASILEIRA
}

\begin{abstract}
Dissertação apresentada à Área de Concentração de Jornalismo Comparado da Escola de Comunicação e Artes da Universidade de São Paulo, como exigência parcial para obtenção do título de Mestre em Jornalismo no Programa de Ciências da Comunicação, sob a orientação da Profa. Dra. Nancy Nuyen Ali Ramadan.
\end{abstract}

\section{UNIVERSIDADE DE SÃO PAULO ESCOLA DE COMUNICAÇÃO E ARTES DEPARTAMENTO DE JORNALISMO E EDITORAÇÃO SÃO PAULO 2005}


FOLHA DE JULGAMENTO

Prof. Dra. Nancy Nuyen Ali Ramadan

Prof. Dr. Celso Frederico

Prof. Dr. Lúcio Flávio R. de Almeida 


\section{DEDICATÓRIA}

A Benedito José Barbosa, herói e mártir da luta do proletariado do campo e da cidade.

Meu avô, que não conheci, mas do qual herdei a Ética, o senso de justiça e fraternidade e a valorização do mundo do trabalho. 


\section{AGRADECIMENTOS}

Ao professor Carlos Marcos Avighi, pelas horas dedicadas, pela paciência e pelos vários conselhos ao longo do trabalho. Também por acreditar no projeto, durante o processo de seleção. Em sua memória e em sua homenagem.

À minha orientadora, professora, Nancy Nuyen, que aceitou assumir a orientação do trabalho após o lastimável falecimento do professor Carlos Avighi e que me ajudou e incentivou nos momentos decisivas da redação.

À toda minha família - meus pais Benedito e Maria, irmãos Marcos, Sueli, Sônia e Odair, à minha esposa, Ana Paula e filha Bruna - pela grande compreensão e apoio, principalmente quando perdi o emprego em decorrência da opção em fazer o Mestrado.

Ao meu amigo Flávio Carvalho, que sempre me incentivou a seguir os estudos e se dispôs a perder uma parte de seu salário para que eu pudesse ter uma renda durante o período do curso. Também pela eterna inspiração de sempre compreender o coração do próximo.

Aos vários profissionais e amigos que, de uma forma ou outra, contribuíram para minha formação acadêmica, desde a D. Neusa e "Seu" Evair do antigo primário, passando pelos professores do Colégio Quarup, até os mestres da Universidade Metodista,da PUC e da USP

Aos meus alunos, que souberam aceitar um professor em início de carreira, e retribuíram em aprendizagem o esforço do meu trabalho. Em especial à primeira turma que lecionei História do Jornalismo: a química de cada aula serviu de inspiração para solucionar trechos difíceis e muito do conteúdo desta dissertação foi debatido em sala. Obrigado pelo imenso carinho e pelo incrível incentivo de ousar lutar e ousar vencer!

Aos jornalistas Heródoto Barbeiro, Vicente Adorno, Luis Mota, José Arbex, Igor Fuser e Patrícia Verdugo pelas entrevistas concedidas.

Finalmente, aos heróis da América Latina, anônimos ou não, que se dedicam à luta pela dignidade deste continente. 


\title{
Ao professor Carlos Marcos Avighi
}

\section{Plegaria a un labrador}

\author{
Victor Jara, 1969 \\ Levántate y mira la montaña \\ de donde viene el viento, el sol y el agua. \\ Tú que manejas el curso de los ríos, \\ tú que sembraste el vuelo de tu alma. \\ Levántate y mírate las manos \\ para crecer estréchala a tu hermano. \\ Juntos iremos unidos en la sangre \\ hoy es el tiempo que puede ser mañana. \\ Libranos de aquel que nos domina \\ en la miseria. \\ Tráenos tu reino de justicia \\ e igualdad. \\ Sopla como el viento la flor \\ de la quebrada. \\ Limpia como el fuego \\ el cañón de mi fusil. \\ Hágase por fin tu voluntad \\ aquí en la tierra. \\ Danos tu fuerza y tu valor \\ al combatir. \\ Sopla como el viento la flor \\ de la quebrada. \\ Limpia como el fuego \\ el cañón de mi fusil. \\ Levántate y mírate las manos \\ para crecer estréchala a tu hermano. \\ Juntos iremos unidos en la sangre \\ ahora y en la hora de nuestra muerte. \\ Amén.
}


BARBOSA, ALEXANDRE. A solidão da América Latina na grande imprensa brasileira. 2005. 237 f. Dissertação (Mestrado) - Escola de Comunicação e Artes, Universidade de São Paulo, São Paulo, 2005.

\section{RESUMO}

Esta dissertação investiga os fatores que dão pouco espaço qualitativo e quantitativo para a América Latina no noticiário da grande imprensa. O estudo é baseado em dois eixos: o ambiente sócio-histórico e o ambiente jornalístico. É da intersecção destes campos que se monta o cenário de solidão da América Latina. A pesquisa demonstra que o continente latino-americano é cindido, por processos históricos, no que defini como "América Latina Oficial" e na "América Latina Popular". A grande imprensa é o aparelho ideológico da "América Latina Oficial" como a imprensa alternativa é da "América Latina Popular". Desmonta-se o mito da imparcialidade e conclui-se que para a América Latina não ser condenada à solidão é preciso desenvolver e estudar os movimentos sociais latinoamericanos, incluindo seus processos de comunicação.

Palavras-chave: Comunicação na América Latina; jornalismo latino-americano, imprensa alternativa; noticiário de grande imprensa; movimentos sociais latinoamericanos. 
BARBOSA, ALEXANDRE. The isolation of Latin America in the Brazilian mass media news. 2005. 237 f. Dissertation (Master) - Escola de Comunicação e Artes, Universidade de São Paulo, São Paulo, 2005.

\begin{abstract}
This dissertation research the factors which exclude Latin America from mass media news. The study is based in two axles: the social-historic environment and the journalistic environment. Through the intersection of these axles it sets the scene for the exclusion of Latin America. The research demonstrates that, by historical processes, the Latin American continent is splited in Official Latin America anda Popular Latin America. The mass media is the ideological tool of official Latin America while the alternative press refers to the Popular Latin America. Undone the myth of impartiality, it's necessary to develop and study the social latin american movements, including it's processes of comunication, otherwise, the latin american continent will be condemned to the isolation.
\end{abstract}

Keywords: Latin America Comunication; Latin America journalism, alternative press; news media press; Latin America Social Movements. 


\section{SUMÁRIO}

INTRODUÇÃO

1. Metodologia e quadro teórico de referência ….................................................. 22

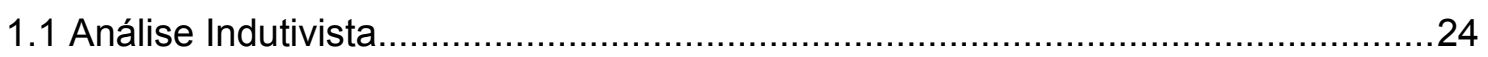

1.2 Modismos: as interpretações de García Canclini................................................... 25

1.3 As falhas nos estudos sobre a comunicação.......................................................... 30

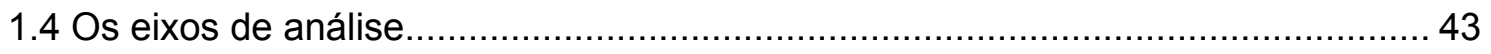

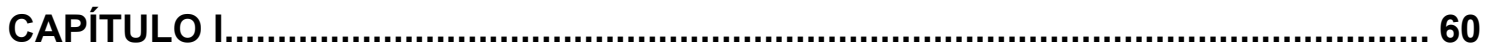

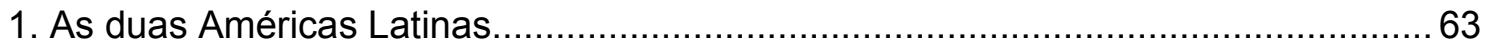

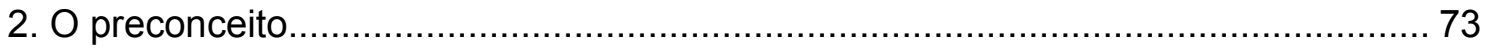

3. A herança colonial e neocolonial na criação das duas Américas Latinas................. 82

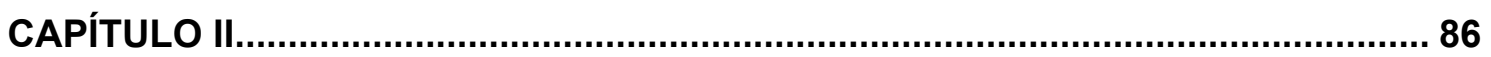

1. A sociedade civil enfraquecida na América Latina popular...................................... 91

1.1 As manifestações populares e a repressão.................................................... 97

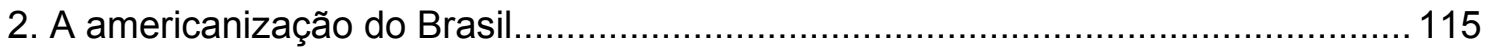

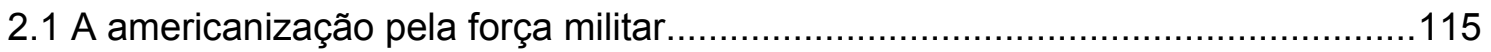

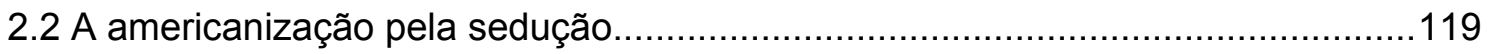

3. Solidão em tempos de globalização: globalização dos mercados

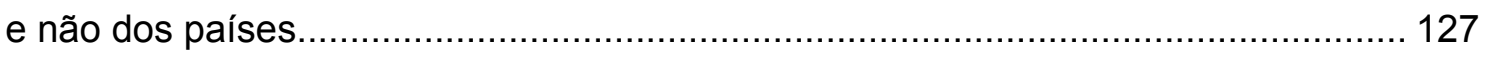

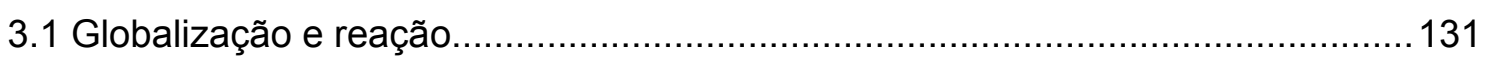

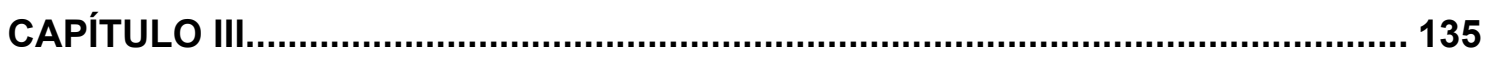

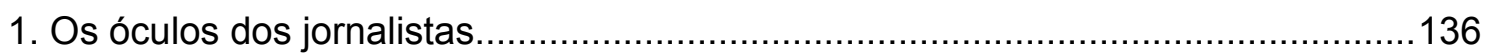

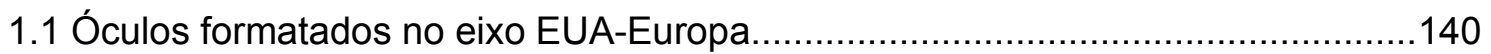

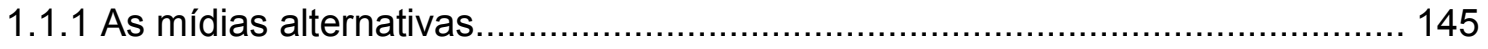

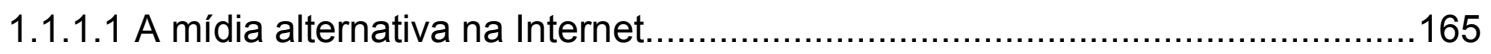

1.2 Óculos de patrões e empregados: o caso dos jornalistas a

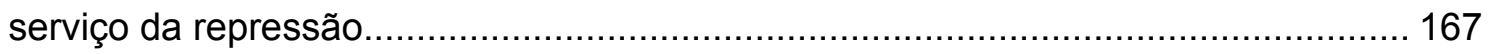

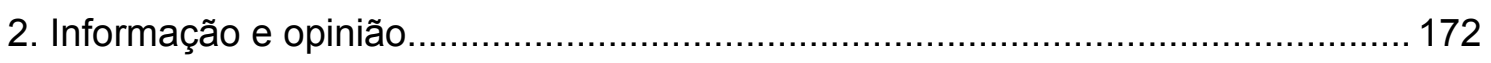

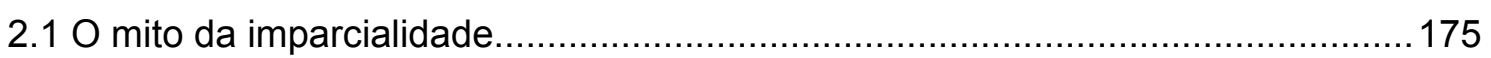

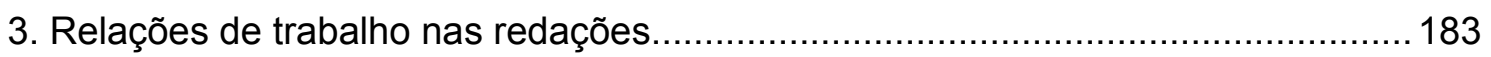

3.1 Transformações provocadas pela Internet: notícias em tempo real, aumento da pressão sobre os jornalistas, menor tempo de reflexão e apuração.......185

4. Agências de Notícias e o trabalho do jornalista da Editoria de Internacional........ 192

5. Formação acadêmica dos jornalistas................................................................ 198

5.1 Mudanças na grade curricular do Ensino Superior de Jornalismo:

uma proposta. 
5.2 A importância da disciplina História da Imprensa: caso dos estudantes do Centro

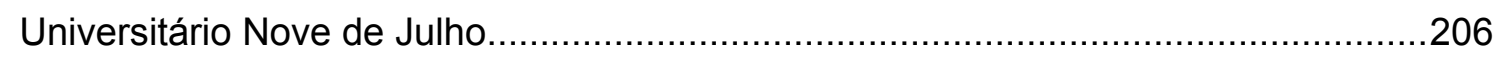

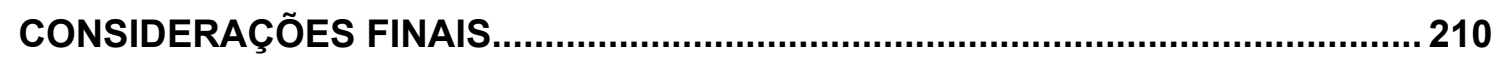

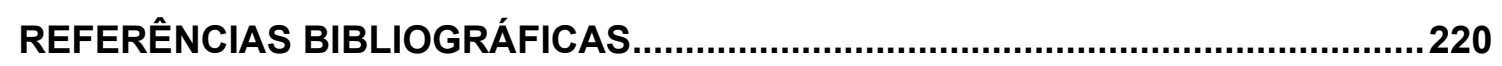

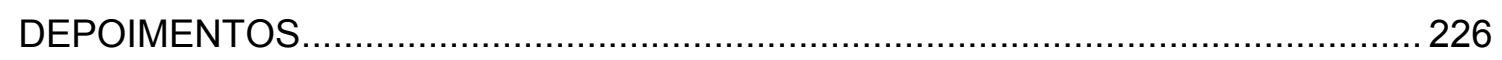

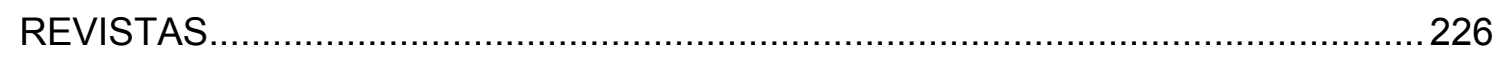

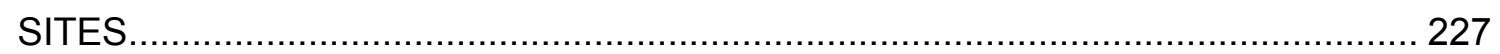

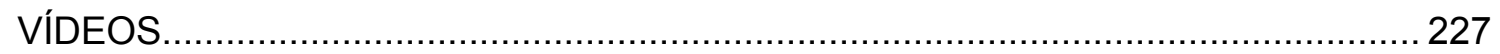

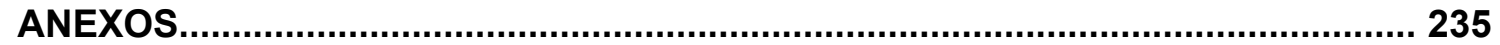




\section{INTRODUÇÃO}

\section{Canción con todos}

Armando Tejada Gómez - César Isella

Salgo a caminar por la cintura cósmica del sur.

Piso en la región más vegetal del viento y de la luz.

Siento al caminar toda la piel de América en mi piel $y$ anda en mi sangre un río que libera en mi voz su caudal.

Sol de Alto Perú,

rostro Bolivia, estaño y soledad, un verde Brasil, besa mi Chile cobre y mineral.

Subo desde el sur hacia la entraña América y total, pura raíz de un grito destinado a crecer y estallar.

Todas las voces, todas, todas las manos, todas, toda la sangre puede ser canción en el viento.

Canta conmigo, canta, hermano americano. Libera tu esperanza con un grito en la voz.

Ciñe el Ecuador

de luz Colombia al valle cafetal.

Cuba de alto son nombra en el viento a Méjico ancestral.

Continente azul

que en Nicaragua busca su raíz para que luche el hombre de país en país por la paz. 
Em 1982, Gabriel García Márquez discursava na cerimônia de entrega do Prêmio Nobel de Literatura e contava, quase 20 anos depois da publicação de Cem Anos de Solidão, como a América Latina continuava um mistério para o mundo ${ }^{1}$. Pouca coisa havia mudado desde os relatos de monstros fantásticos que assombravam os mares. Com uma sombra de esperança, García Márquez dizia que aquela dura realidade da época (golpes de Estado, guerras civis, "desaparecidos" políticos, exilados, ditaduras) finalmente mereceu a atenção do mundo, o que teria levado a Academia Sueca a dar o prêmio a um latinoamericano. Neste discurso, o escritor alertava aos europeus a aprender a olhar e entender a América Latina, não comparando a história latino-americana com a européia. "Creo que los europeos de espíritu clerificador, los que luchan también aquí por una patria grande más humana y más justa, podrian ayudarnos mejor si revisaran a fondo su manera de vernos. La solidaridad con nuestros sueños no nos hará sentir menos solos, mientras no se concrete com actos de respaldo legítimo a los pueblos que asuman la ilusión de tener una vida propia en el reparto del mundo".

Mais de vinte anos se passaram. Quatro décadas depois da publicação da fantástica saga dos Buendía a América Latina parece condenada, definitivamente, "a não ter uma segunda oportunidade sobre a terra" ${ }^{2}$ e os "primeiro-mundistas" de fora e de dentro do continente continuam a olhá-la sem a menor menção de um ato concreto de respaldo. Sufocada por políticas econômicas que reforçam a condição de periferia primárioexportadora, pela corrupção das classes dirigentes cada vez mais aliadas ao capital europeu e norte-americano, a região latino-americana (definida pelo povo, cultura, tradições, folclore, lutas, movimentos sociais e processos de resistência) foi varrida das manchetes dos jornais tal qual a fantástica Macondo foi varrida da História pela tormenta que veio do Norte.

\footnotetext{
${ }^{1}$ MÁRQUEZ, Gabriel Garcia . La Soledad de América Latina: Escritos sobre arte y literatura, 19481984. La Habana, Cuba: Editorial Arte Y Literatura, 1990. (p.504-510).

${ }^{2}$ MÁRQUEZ, Gabriel Garcia. Cem Anos de Solidão. Rio de Janeiro, Ed. Record, 1999.
} 
Curiosa coincidência. García Márquez, em crônica publicada em $1979^{3}$, disse que os escritores latino-americanos deviam reconhecer que a realidade é melhor escritora que eles. Por mais que Márquez tentasse escrever uma fantasia que se distanciava da realidade, não demorava a perceber que os habitantes do cotidiano realizavam as mesmas peripécias das personagens de seus livros. Assim, como numa maldição real, a América Latina foi condenada, pela imprensa brasileira, a ficar no esquecimento.

Nas três últimas décadas do século $X X$, porém, a América Latina ganhou, pelo menos, a atenção dos pesquisadores da área de Comunicação Social. Foi um processo lento. O primeiro passo, foi o reconhecimento da América Latina não apenas como espaço geográfico, mas como região produtora de conhecimento nos processos comunicacionais. Desde 1823, com a Doutrina Monroe (a América para os Americanos), que o continente sempre foi um grande quintal norte-americano, espaço ideal para a instalação de bases militares e para o crescimento da poderosa United Fruit Company (a Mamita Yunai como descreveu Miguél Ángel Astúrias). ${ }^{4}$

Enquanto na Europa e nos EUA os debates sobre a Comunicação Social geravam publicações, teses e Escolas que dividiriam opiniões por todo o mundo, a América Latina sequer tinha um curso de pós-graduação nessa área. As referências bibliográficas continham apenas autores do eixo América do Norte/Europa. Na própria História do continente se repete este processo de abandono e esquecimento - ou opressão e assalto de acordo com o interesse do momento - por parte do Ocidente.

\footnotetext{
${ }^{3}$ Ibid. Op. Cit.p.313-22

${ }^{4}$ SADER, Emir. Século XX: uma biografia não autorizada. O século do Imperialismo. São Paulo:

Editora Fundação Perseu Abramo, 2000.
} 
A Imprensa (não só a latino-americana, mas toda a entidade chamada Grande Imprensa que age mundialmente nos mesmos padrões, principalmente em países capitalistas) dá o mesmo tratamento à região que o dado pelas potências ocidentais. Ora a América Latina desperta interesse (período em que é explorada, vilipendiada, desonrada, estuprada, assaltada), ora é deixada de lado feito um brinquedo velho que já perdeu seu uso e ganha poeira no fundo do porão. A região só sai do limbo do noticiário em situações de excepcionalidade: tragédias, golpes de Estado, violência, abuso de poder, desastres naturais, ou seja, em todas as que reforçam o caráter de periferia. No caso da imprensa brasileira, a América Latina e as periferias do Brasil são a mesma categoria.

A América Latina a que se refere a dissertação compreende todos os países do continente e ilhas ao sul do Rio Grande até a Terra do Fogo com toda a pluralidade étnica, regional, cultural, sócio-econômica e política.

Aqui é necessário observar um erro comum quando se fala a expressão "América Latina": esquecer (propositalmente ou não) a inclusão do Brasil como um país latinoamericano e dos brasileiros como latino-americanos. Por este raciocínio excludente, o termo América Latina seria referente à outra América (todo o resto do continente e ilhas com exceção do Brasil). Não há razões para fazer essa exclusão. Além de história, geografia e características comuns a todos países e ilhas, não se pode falar de barreiras de idiomas. As diferenças de idioma entre o Brasil e os demais países não criam barreiras de identidade principalmente porque há muito mais fatos históricos, processos sociais que mais aproximam os países latino-americanos que os distanciem. "A história da América Latina é uma história de lutas sociais", diz Octavio lanni e por este pensamento o Brasil, por todas as suas lutas sociais, se encaixa muito mais na América Latina do que na América do Norte.

Portanto, dizer que o jornalismo de grande imprensa não tem olhos para a América Latina implica dizer que não tem olhos também para o Brasil. O Brasil retratado nos meios de comunicação de massa da grande imprensa é o Brasil dos gabinetes palacianos, dos mercados, das elites, o Brasil que se identifica com a Europa, com os EUA. Evidente que este Brasil não representa todo o país. O Brasil das periferias, das lutas sociais, da cultura 
popular, o Brasil que é América Latina recebe da grande imprensa o mesmo tratamento dos demais países latino-americanos. O Brasil América Latina só ganha destaque quando a notícia apela para o sensual, para a barbárie, para o reforço da condição de periferia.

A solidão da América Latina no jornalismo brasileiro é ainda mais grave pois o Brasil é solitário dentro dos seus próprios meios de comunicação. O jornalismo praticado nos grandes e tradicionais veículos de comunicação é um espelho distorcido que não reflete a complexa sociedade em que se insere. Afinal, este jornalismo é orgânico da nação burguesa e não das outras nações existentes na pluralidade latino-americana. É natural, portanto, que este jornalismo reproduza os mesmos procedimentos oscilatórios da burguesia ao longo de toda a história, da colonização, passando pelas oligarquias nacionais e golpes contrarevolucionários às estratégias modernizantes.

A primeira vez que a América Latina efetivamente ganha atenção do mundo é pouco antes da entrada dos EUA na II Guerra Mundial. ${ }^{5}$ Interessados em frear o desenvolvimento do nazismo no Atlântico Sul e preocupados em ter como aliados os governos destes países, megaempresários como Nelson Rockefeller e burocratas do Estado norte-americano se uniram para seduzir as nações latino-americanas e atraí-las para o modelo de capitalismo estadunidense. Como se verá, visitas do presidente Roosevelt, produções de cinema e programação de rádio específica para o México e Brasil eram alguns dos recursos utilizados para conseguir essa sedução. Uma vez derrotado o nazismo na Europa, a América Latina é devolvida à condição de quintal.

Com o acirramento da Guerra Fria entre EUA e URSS, durante os anos 60, a América Latina voltou a ganhar importância no cenário mundial, agora como uma das regiões de conflito. O período da Guerra Fria foi caracterizado pelo cientista francês Raymod Aron como aquele em que a guerra era improvável e a paz, impossível. EUA e URSS não se agrediam diretamente porque tinham tanto poder de destruição que, se ocorresse uma guerra, com certeza, seria a última. As duas potências disputavam áreas de influência, como a África e a Ásia, apoiando, com dinheiro, pessoal e armas, um ou outro lado em ${ }_{5}^{5}$ TOTA, Antonio Pedro. O Imperialismo Sedutor. São Paulo: Companhia das Letras, 2000. 
conflito, como ocorreu no Vietnã. Após a Revolução Cubana de 1959 e com a declaração do seu caráter socialista e anti-imperialista, em 1961, a América Latina, passa, definitivamente, a pertencer ao cenário mundial. Além de ser o quintal norte-americano era também uma região de interesse, uma área de influência em disputa. Graças à Guerra Fria a América Latina ganha as manchetes dos jornais.

As tentativas de exportar o modelo cubano levaram o continente a uma sucessão de episódios de guerrilhas (Che Guevara se aventurou na selva boliviana a iniciar um novo foco guerrilheiro, os Sandinistas chegaram ao poder na Nicarágua e a Frente Farabundo Martí de Libertação Nacional comoveu o mundo com a guerra civil estabelecida contra o governo salvadorenho) reprimidas duramente por ditaduras militares sangrentas patrocinadas pelas contra-tentativas norte-americanas de conter o comunismo em qualquer parte do planeta (o Brasil viveu vinte anos sob o regime militar contabilizando trezentos e cinqüenta mortos e desaparecidos; no Chile o palácio presidencial de La Moneda foi bombardeado, o presidente Salvador Allende morreu na resistência ao golpe e o General Augusto Pinochet comandou uma sangrenta ditadura com cerca de trës mil mortos e desaparecidos e na Argentina o governo militar soma a espantosa cifra de trinta mil desaparecidos para citar apenas alguns países do conesul).

Foram estes tristes fatos que levaram a América Latina a "pertencer" ao mundo nas décadas de 1960, 1970 e início da década de 1980. Porém, com o fim da Guerra Fria, com o enfraquecimento do regime cubano, com a derrota de praticamente todos os movimentos guerrilheiros e com o fim dos governos militares autoritários de direita o continente voltou a ser um grande quintal norte-americano durante os anos 80 e 90.

Os últimos anos do século XX mostraram um novo tipo de exploração. $O$ subcontinente não era apenas mais uma terra livre para os latifúndios da United Fruit. A estratégia de dominação foi diferente e começou pelo Chile com a chegada de tecnocratas e economistas de Chicago (os Chicago Boys), que, num processo de cooperação do governo chileno com os EUA implantaram as bases econômicas do que seria conhecido mais tarde como neoliberalismo. 
O neoliberalismo se caracteriza, no plano econômico, por uma política recessiva de diminuição do Estado e favorecimento das empresas privadas. A justificativa da diminuição do Estado e da contenção de seus investimentos é dada pelo ajuste fiscal das contas públicas. O empréstimo de dólares — solução para controlar a hiper-inflação que assolava a América Latina nos anos 80 - feito pelos bancos internacionais e pelo Fundo Monetário Internacional (FMI) foi condicionado ao cumprimento de exigências de saldo positivo de dinheiro em caixa pelos governos nacionais. Para manter o saldo positivo, os governos passaram a cortar gastos sociais, como investimento nos setores de infra-estrutura, saúde, educação e previdência. As empresas estatais responsáveis por estes setores foram privatizadas e a população foi incentivada a utilizar apenas os serviços particulares de educação, saúde e previdência. Estradas, ferrovias, empresas de telefonia, eletricidade, entre outras eram vendidas a grupos privados e de capitais estrangeiros (europeus e norteamericanos principalmente). Os países latino-americanos que recorreram à política neoliberal, sufocados pela hiperinflação e traumatizados com os sucessivos desastres das políticas de controle, foram se endividando e seus patrimônios ativos desmoronaram. A Argentina privatizou até as suas "jóias da coroa", como a estatal produtora de combustíveis. ${ }^{6}$ O primeiro impacto das políticas neoliberais foi o controle da inflação, mas os efeitos estavam incubados tal qual uma bomba relógio.

Foi durante este período de fixação e aparente sucesso do neoliberalismo, pouco antes de surgirem os primeiros sinais de decadência, que os estudos sobre a Comunicação na América Latina ganharam fôlego. O fim da Guerra Fria, a derrocada do Leste Europeu, a abertura política nas antigas ditaduras, o incremento tecnológico dos meios de comunicação, o início da era digital de telecomunicações transmitiam a sensação de que o mundo inteiro se comunicava por meio da globalização (EUA e Rússia sentavam lado a lado para assinar tratados, cena antes impossível de ser vista).

A ordem mundial, dizia-se, não era mais bipolar, mas multipolar e os blocos econômicos se formavam: a Comunidade Européia discutia a criação de uma moeda única. ${ }^{6}$ PETRAS, James. Armadilha Neoliberal. E alternativas para a América Latina. São Paulo: Xamã. 1999. 
Na Ásia, os Tigres Asiáticos do sudeste eram exemplo de como um país até então tido como de Terceiro Mundo poderia saltar para o Primeiro Mundo; o Tratado de Livre Comércio da América do Norte (NAFTA, em inglês) foi assinado em 1994, aparentemente colocando lado a lado, EUA, Canadá e México. Na América do Sul, Paraguai, Uruguai, Argentina e Brasil discutiam a criação do Mercosul.

A tecnologia evoluiu. Eventos eram transmitidos ao-vivo e via satélite de uma parte a outra do globo e a Internet aparecia como o grande meio democratizador da informação. Os computadores ligados à rede podiam se comunicar e trocar dados pela linha telefônica. A telefonia celular permitia a qualquer cidadão se comunicar com outro sem a necessidade de um fio.

Os estudiosos da Comunicação Social se perguntavam se realmente a América Latina continuava sua saga de solidão com todo o planeta vivendo essa fervura de integração e comunicação. Este foi o segundo passo dos estudos sobre a América Latina: o reconhecimento de que o continente, apesar de toda a onda de globalização e telecomunicação instantânea, continuava sem espaço no jornalismo brasileiro. É preciso destacar a importância e a coragem destes trabalhos que despertaram a atenção para a América Latina, assunto quase que enterrado na academia desde o enfraquecimento da CEPAL (Comissão Econômica para a América Latina). Também é preciso entender o contexto em que estes estudos foram produzidos. Michel de $\mathrm{Certeau}^{7}$ ensina que para toda a obra é necessário compreender as condições de produção dos autores.

Diante do cenário aqui descrito era natural que estes estudos alertassem para o isolamento da América Latina no noticiário - mesmo diante da febre globalizante - mais do que encontrar todas as explicações para este fenômeno. Em cada um dos trabalhos publicados sobre o assunto, a causa para a ausência da América Latina do noticiário era até mesmo maniqueísta. A "culpa" recaía ora no caráter capitalista das empresas jornalísticas, ora na capacidade intelectual dos jornalistas e - freqüentemente - nas características da sociedade neoliberal.

\footnotetext{
${ }^{7}$ CERTEAU, Michel de. A Escrita da História. Rio de Janeiro: Forense Universitária, 2002.
} 
Passado o impacto do neoliberalismo e adquirindo um olhar mais histórico sobre a problemática da Comunicação, é possível observar que a ausência da América Latina do noticiário tem implicações maiores que a simples atribuição à preguiça intelectual dos jornalistas ou a mera conseqüência do caráter capitalista das empresas aguçado pela corrente neoliberal. O neoliberalismo não é mais consenso. Hoje as nações latinoamericanas estão atadas ao arrocho da manutenção do superávit primário - exigência maior do crédito do FMI. O engessamento do Estado elevou contradições, concentrou renda e aumentou o desemprego e alargou o já enorme abismo social. O capital estrangeiro domina setores estratégicos como telecomunicações e transportes. A economia está totalmente financeirizada. O setor produtivo não consegue competir com os fabulosos lucros do capital especulativo que não gera empregos nos países hospedeiros. As cidades latino-americanas perderam força com a falência das indústrias. Fábricas deram lugar a centros de consumo em que só pequena parcela da população tem acesso. Elevou-se a ideologia do sucesso a todo custo e do individualismo. Sindicatos se enfraqueceram. A ideologia do público perdeu espaço para o privado, conseqüência da ideologia vendida para justificar a privatização. Os partidos políticos perderam significado.

A Internet não se revelou o meio democratizante como nos primeiros anos e grande parte da população latino-americana ainda não acessa a rede. Se já existiam diferentes nações dentro de cada país latino-americano, após o furacão neoliberal essas nações se dividiram ainda mais, especialmente entre os contemplados ou não pela "modernização" neoliberal.

A formação das nações dentro da nação latino-americana será vista no Capítulo I, que também vai discutir os conceitos de nação e de formação dos Estados latinoamericanos. O que passa pelo ideal de integração, nascido na Pátria Grande de Simón Bolívar, décadas mais tarde revitalizado por Che Guevara e hoje, quase esquecido, raquítica e debilmente discutido nas relações comerciais. O Capítulo I também vai debater a questão da aceitação do outro, as características do caráter nacional e o delicado, mas necessário, debate sobre preconceito. 
Além dos dados já apontados e fartamente analisados por trabalhos anteriores, este estudo mostram que a ausência do continente no noticiário, além das causas já citadas e que efetivamente fazem parte do cenário, tem raízes históricas que influenciaram diretamente no formato de jornalismo que se pratica no Brasil como será demonstrado no Capítulo II da dissertação, tem raízes nas relações de trabalho praticadas nas redações, está ligada ao modo de produção jornalístico e é conseqüência da formação da sociedade civil latino-americana.

O jornalismo brasileiro, desenvolvido sob a influência do imperialismo norteamericano, em conjunto com a herança histórica de um continente recheada de episódios em que o subalterno jamais teve condições de se manifestar (e quando teve foi reprimido violentamente) gerou sociedades civis - formada tanto pelos jornalistas como pelos receptores (leitores, ouvintes, telespectadores) e especialmente por uma elite que muitas vezes se confunde com o veículo de comunicação - usuária de categorias para selecionar o que deve e o que não deve ser notícia, que, definitivamente, não enxerga a América Latina, como será visto também no Capítulo II.

Neste mesmo capítulo será desmontado o mito da globalização como forma de inserir a América Latina no noticiário. Será provado que o que se globalizou foram apenas os mercados, portanto, o que não serve para o mercado não é de interesse do jornalismo. Autores, como Néstor García Canclini e Beatriz Sarlo, descrevem muito bem como a nova ordem capitalista deteriora os espaços públicos onde se poderia cultivar a possibilidade de novas formas de comunicação que abrangessem não só o que é relevante para o mercado.

Para que se possa obter o quadro completo, não se deve esquecer o modo como se pratica jornalismo no Brasil, como vai demonstrar o Capítulo III desta dissertação. Nele são apresentadas as raízes do desenvolvimento da empresa jornalística nos anos 40 e 50 o que correspondeu ao período de americanização do Brasil. A concorrência pelo índice de audiência e tudo o que se origina dessa disputa: a obsessão pelo "ao-vivo", a disputa pelo "furo" e o aumento de notícias sem profundidade, veiculadas apenas para atingir o maior número de pessoas possível; a exploração do trabalho assalariado do jornalista; a relação 
de poder nas redações e o já citado caráter capitalista destas empresas são fatores que, interligados, condenam a América Latina à solidão.

Esta dissertação vai mostrar que a América Latina não é vista com interesse pelas empresas donas dos meios de produção por não estar inserida no enquadramento dos óculos nem dos produtores de notícias e nem dos receptores de notícias pertencentes às "nações burguesas" dentro de cada região latino-americana. Estes receptores - que não são representantes de toda a pluralidade latino-americana - foram transformados em consumidores. O processo de mercantilização das relações de comunicação, a criação do processo de "contrato para redação do manual de entrada no primeiro mundo" em que se transformou o jornalismo da grande imprensa e a transformação dos receptores em consumidores estão na Metodologia de pesquisa adotada. 


\section{Metodologia e Quadro Teórico de Referência}

Esta é uma dissertação em negativo. ${ }^{8}$ Não há um objeto de pesquisa, mas a ausência dele. A angústia de procurar uma resposta para a solidão da América Latina começa pelo fato de que não há explicação suficiente para a exclusão de publicação de material qualificado sobre a região na mídia. É como se as palavras sobre a América Latina desaparecessem dos noticiários.

Um objeto ausente, e realidade tão complexa, de diferentes nações e diferentes jornalismos praticados dentro de um mesmo país não podem ser interpretados por uma única escola de pesquisa. Não há um único método a ser aplicado. Esta dissertação não pode seguir os rígidos padrões científicos e se concentrar num único campo de análise. A metodologia para se compreender a América Latina precisa ser criada. É necessário adotar um quadro teórico igualmente complexo, que una pensadores das Ciências Sociais e Políticas e da Comunicação não só latino-americanos como também europeus. Se a formação do pensamento latino-americano pode ser vista como a história da idéia de América Latina ${ }^{9}$, a formação do pensamento comunicacional se confunde com a História da América Latina. Portanto, contar a história da região - com todas as incoerências e conflitos - é contar a história da comunicação latino-americana.

Para lanni, "uma parte importante do pensamento e prática na América Latina organiza-se com base em interpretações sintetizados nos conceitos de civilização e barbárie, instabilidade política crônica, sociedade civil débil, Estado forte, raça cósmica, Nossa América, lutas sociais, revolução burguesa, revolução socialista, questão nacional. Elas influenciam partidos políticos, movimentos sociais, correntes de opinião pública, governantes, técnicos, militares, membros de igrejas, intelectuais e outros". Logo, essas interpretações também influenciam as teorias sobre a Comunicação Social. "É possível,

\footnotetext{
${ }^{8}$ Agradeço ao professor Celso Frederico da ECA/USP, que fez a observação do objeto em negativo durante o Exame de Qualificação para esta Dissertação de Mestrado.

${ }^{9}$ IANNI, Octavio. O Labirinto latino-americano. $2^{a}$ edição. Petrópolis, Rio de Janeiro: Paz e Terra, 1993.
} 
ainda, reconhecer que essas interpretações expressam tendências, escolas, ou melhor, estilos de pensamento". ${ }^{10}$

lanni afirma que o pensamento que constitui a América Latina se compõe de tendências e controvérsias polarizadas em torno de fundadores, seguidores e precursores. Formam escolas, grupos e estilos de pensamento que, por sua vez, compreendem as respectivas ortodoxias, dissidências e opositores. Segundo lanni, "as diversidades e antagonismos não impedem que todos polarizem-se no processo de construção da problemática latino-americana como idéia e história".

Há, porém, dois aspectos importantes para tornar o quadro completo. O primeiro está no fato de que essas correntes de pensamento se misturam - ou são meras transposições e adaptações - das teorias, temas e modas vigentes na Europa e nos Estamos Unidos. "É comum verificar que o que foi moda em Paris, Londres e Nova lorque torna-se moda depois, de modo caricato, aqui e ali, na América Latina". ${ }^{11}$ Se o processo acontece em todos os campos do pensamento, na Comunicação Social ele é ainda mais forte.

O segundo aspecto é que a América Latina é demasiado heterogênea para se fazer um pensamento universalizante. Essa heterogeneidade não é só de países e histórias, mas diz respeito, principalmente à interpretação do que é a nação latino-americana, desde as guerras de independência até as controvérsias sobre autoritarismo e democracia ou capitalismo e socialismo; desde Bolívar e Artigas, passando por Haya e Mariátegui até Sandino e Allende. Como se verá, há várias nações na nação latino-americana. De acordo com lanni, essas nações se mesclam e diferenciam, convivem e antagonizam, conforme a época e o jogo das forças sociais. Uma é a nação burguesa, oficial, dominante. Outra é a popular, camponesa e operária, indígena e negra. Neste caso, a problemática das análises é saber a qual América Latina se referem. O fato é que os Meios de Comunicação de Massa, a burocracia estatal, as classes dominantes, parte da intelectualidade e a elite são ligados à nação oficial.

\footnotetext{
${ }^{10}$ IANNI, Op. Cit. p $10-13$.

${ }^{11}$ Idem.
} 
Portanto, não é possível transferir integralmente escolas, grupos e interpretações da Comunicação sem correr o risco de fazer uma análise parcial - e até mesmo preconceituosa - da América Latina. Se é verdade que a grande imprensa pertence à burguesia latinoamericana, também é verdade que existe uma comunicação alternativa, ligada a setores populares, mas, com certeza com forças diferentes de atuação.

Tanto o método dedutivista, quanto o indutivista, são falíveis como única interpretação das condições de produção do jornalismo na América Latina. Por explicações baseadas no método dedutivista podem ser entendidas todas aquelas que atribuem a fatores externos a influência na prática jornalística, como a influência do imperialismo, a ideologia capitalista e os interesses burgueses de donos das empresas de comunicação e dos anunciantes.

Por explicações baseadas no método indutivista se entendem todas as que estudam a América Latina como um continente que resiste à dominação capitalista e, portanto, o isolamento latino-americano acontece pelo fracasso deste processo de resistência.

Os autores pesquisados adotam análises imparciais da realidade latino-americana. É por isso que esta dissertação trabalha com a hipótese de que os estudos sobre a ausência da América Latina no noticiário são incompletos. Há sempre uma falha de interpretação, como se verá a seguir.

\subsection{Análise Indutivista}

Os autores que se valem do indutivismo creditam força na cultura política das classes populares. Eles trabalham com a idéia de que há uma contraposição clara entre cultura subalterna (caracterizada pela produção cultural dos movimentos sociais, como jornais, livros, músicas, filmes) e a cultura hegemônica dos meios de massa da indústria capitalista. "Alguns grupos insistem tanto na necessidade política de defender a independência da cultura subalterna - fundamentando essa exigência em Gramsci que ambas (subalterna e hegemônica) são pensadas como exteriores uma à outra. Na pressuposição de que a tarefa da cultura hegemônica é dominar, enquanto da subalterna é 
resistir, muitos estudos parecem não ter mais nada a investigar além dos modos pelos quais uma e outra cultura desempenham seus papéis nesse roteiro". ${ }^{12}$

Pela teoria indutivista, a saída para que a América Latina tivesse espaço de qualidade no noticiário seria a criação pelos movimentos sociais latino-americanos ou pela sociedade civil latino-americana, consciente de seu dever de se manifestar, de meios de comunicação próprios, estabelecendo uma "guerra de guerrilhas" entre a mídia hegemônica e a popular. No entanto, esta interpretação não contempla a questão do desaparecimento destes veículos de comunicação criados e da impossibilidade destes mesmos veículos (revistas como Atenção!, Caros Amigos, jornal Brasil de Fato) alterarem, de fato, a estrutura da Comunicação Social. Se esta guerra ainda não se estabeleceu totalmente, talvez o tempo decorrido para que isto ocorra não tenha sido suficiente e fica a oportunidade de pesquisa para futuros trabalhos. O que há, de fato, é a necessidade de fortalecimento dos movimentos sociais e das classes subalternas da América Latina Popular como um passo anterior ao fortalecimento dos veículos altarnativos.

\subsection{Modismos: as interpretações de García Canclini}

Um dos pensadores que está mais em "moda", desde os anos 90, nos estudos da Comunicação social é Néstor García Canclini. O intelectual argentino afirma ${ }^{13}$ que o método dedutivista "desenvolve uma concepção de poder que chamaríamos de 'teológica' já que o imagina como onipotente e onipresente. A conseqüência metodológica é a crença de que basta o estudo dos objetos econômicos das mídias e da estrutura ideológica de suas mensagens para que se possam deduzir as necessidades que geram nos espectadores. Não se reconhece nenhuma autonomia às culturas populares, nem à relação entre consumidores, objetos e espaço social." ${ }^{14}$ Essa relação consumidores - objeto [mídia] e espaço social é adotada por uma corrente de interpretação da América Latina, representada

\footnotetext{
${ }^{12}$ CANCLINI, Néstor García. Op. Cit.

${ }^{13}$ CANCLINI, Néstor Garcia. Gramsci e as culturas populares na América Latina in COUTINHO, Carlos Nélson \& NOGUEIRA, Marco Aurélio (Orgs). Gramsci e a América Latina. Rio de Janeiro:

Paz e Terra, 1993. p. 67.

${ }^{14}$ Idem.
} 
por Beatriz Sarlo, Martín-Barbero e García Canclini, que trabalha com o conceitos das mediações entre os atores da sociedade, um método mais fiel aos escritos de Gramsci. Esta questão da mediação é o que há de melhor na obra de Canclini.

Porém, seguindo uma tendência dos pensadores latino-americanos de "esquecer" interpretações passadas e adotar novas, algumas vezes diametralmente opostas, como apontou Francisco de Oliveira no texto O Ornitorrinco ${ }^{15}$, Canclini muda o caminho da sua obra.

Canclini afirma que a metodologia dedutivista, ao atribuir características hegemônicas aos meios de comunicação, erra na definição do que é o "poder". Para ele, o poder não é um bloco institucional com uma tarefa definida de manipular e dominar e nem sempre é verticalizado. O poder se estabeleceria por meio de relações sociais disseminadas pela sociedade. "São complexas as relações de poder, pois não há um rei sem súditos, mesmo que haja rebeldes, há os que 'aceitam' a divindade do rei." O poder, de acordo com Canclini, é formado de relações de força múltiplas que se formam e atuam na produção, nas famílias e nos indivíduos. De acordo com o autor uma explicação mais simples é colocar as responsabilidades pela dominação na burguesia, no imperialismo ou nas mídias.

\footnotetext{
${ }^{15}$ OLIVEIRA, Francisco. Crítica à razão dualista. O Ornitorrinco. São Paulo; Boitempo Editorial, 2003.
} 
O erro desta interpretação está na universalização. Se há, verdade, os que "aceitam" a dominação também há os que se rebelam com todas as forças contra ele. O fato desta luta ser desigual não significa que ela não exista. Acreditar que o poder é também horizontal pois parte da sociedade o aceita é não enxergar a luta, por exemplo, dos trabalhadores sem terra ou dos indígenas do sul do México.

Pode-se considerar simplista a explicação de a publicação de notícias ligadas apenas ao centro do capitalismo só acontece em função de seu domínio econômico. Por mais que seja simples e que outros fatores contribuam na formação deste cenário, não há como negar que a dominação do centro econômico exista e opere de forma decisiva no diaa-dia da seleção de notícias contribuindo para aumentar a circulação circular da informação.

Outro ponto polêmico da obra de Canclini é a teoria do contrato: a afirmação de que as relações de dominação só se mantêm e se reproduzem porque há um intercâmbio de serviços entre dominadores e dominados. "O povo encontra na ação hegemônica algo útil às suas necessidades. Talvez pudéssemos compreender por que a televisão é tão atraente, até mesmo no que se refere à publicidade de objetos que não podem ser comprados, se, além de criticar a dominação, examinássemos o serviço que ela presta às classes populares como 'manual de urbanidade', que indica como vestir, comer e expressar os sentimentos na cidade. Reconhecer isso não significa minimizar a exploração. Ajuda a compreender por que os oprimidos, percebendo que esse serviço não é inteiramente ilusório, dão seu consenso, emprestam certa legitimidade à hegemonia”. ${ }^{16}$

${ }^{16}$ CANCLINI, Néstor García. Op. Cit. p. 69 
De acordo com Canclini, o jornalismo encontra na sociedade latino-americana o empréstimo de legitimidade: é o público receptor que todos os dias legitima os jornais, telejornais e programas radiofônicos transformando os jornalistas destes veículos em verdadeiros porta-vozes de suas aspirações. Aspirações estas que vão desde ações mais concretas como o uso do jornalismo como ponte de acesso ao poder público até situações mais abstratas, como sentir-se pertencente ao universo palaciano de artistas televisivos. 0 jornalismo é usado como ponte de acesso quando, por exemplo, os moradores de uma rua chamam o repórter do telejornal regional para denunciar problemáticas locais como buracos, falta de asfalto ou sinalização. O jornalismo também se presta a aproximar duas classes distintas e até antagônicas quando, por exemplo, veícula reportagens sobre a vida pessoal de artistas de telenovelas ou astros da música, mostrando a casa, os empregados ou a viagem de férias destas "personalidades".

Ainda para Canclini, em nenhum dos casos partiu de um interesse maniqueísta dos proprietários dos meios de comunicação a ordem de veicular tais matérias. Elas só foram publicadas por serem consideradas de interesse do público. Por esta análise, a América Latina sofre porque o público não apresenta a necessidade de conhecer o continente e, portanto, os veículos de comunicação não se sentem obrigados a noticiar eventos ligados a ele

A análise é verdadeira apenas em parte. Pode-se dizer que o leitor/ouvinte/telespectador não "exige" a presença da América Latina no jornalismo porque, ao ler/ouvir/ver notícias relacionadas ao eixo EUA - Europa, se sente parte integrante dele. A publicação destas notícias presta um papel de "manual de civilização mundial", ou, em outras palavras: uma receita de como pertencer ao "mundo desenvolvido". Receber notícias da periferia - tanto do mundo quanto da cidade - apenas seria aceitável se elas reafirmarem este caráter periférico de um mundo ao qual o receptor não se sente participante.

De acordo com essa análise, um dos fatores que contribuem para a ausência da América Latina do noticiário tem, na essência, a mesma explicação dos fatores que contribuem para a ausência de notícias sobre os bairros mais humildes de São Paulo no 
noticiário local. A periferia de São Paulo não entra nas manchetes, a não ser que estas manchetes sejam de notícias "espetaculares": tragédias como enchentes, seqüestros, terremotos, fugas e violência desmedida. Essas notícias apenas reforçam que a periferia é o lugar dos excluídos (mesmo que ela esteja na esquina de casa), enquanto que o noticiário de variedades sobre a vida de artistas, sobre compras em shoppings ou sobre o círculo (circo) do poder reforça o caráter civilizado do mundo (mesmo que ele esteja muito distante de casa). Para Canclini, há, portanto, uma espécie de "contrato" entre receptores e produtores de notícia, do qual constam as diretrizes para que os jornalistas reproduzam diariamente o manual de civilidade dos seus receptores.

O erro desta análise está, novamente, em homogeneizar o público. Dizer que há apenas contratantes e contratados é esquecer as diferentes nações latino-americanas. A relação de contrato se estabeleceria apenas na América Latina Oficial - ou burguesa - ou seja, entre a América Latina "branca", da elite das metrópoles e do litoral e seus respectivos meios de comunicação. Assegurar que há um "contrato" que firma as bases da subordinação e da exploração é apagar por completo os milhões de famintos que vivem abaixo da linha da pobreza nas cidades latino-americanas. Os milhões de analfabetos. Os milhões de desempregados. A população negra e índia desprezada. Os excluídos de todos os países. Os moradores de bairros em que sequer não há luz elétrica. Para eles não há relação de contrato. Os meios de comunicação não se destinam a eles. O mito do "públicoalvo que exige notícias dos EUA" não as inclui.

Não é só a relação de "contrato" que transforma os leitores da revista semanal Veja em consumidores. O interesse dos grandes meios de comunicação, como qualquer outra propriedade capitalista, é gerar lucro. E a maneira pela qual os meios de comunicação geram lucro é a venda publicitária. A equação da publicidade é simples: mais leitores, mais anúncios mais caros. Um veículo que não alcance extratos selecionados ou amplos da população não gera lucros. Por isso, os veículos de comunicação se especializam em assuntos ônibus (para milhares de leitores) e se transformam em catálogos de vendas de 
produtos, seja por meio dos anúncios ou das próprias notícias. Assim, acreditar que tudo se resume à relação público-mídia é cair também numa explicação falível e simplista.

Além da complexa relação jornalista-receptor existem os demais fatores citados por outros estudiosos da Comunicação (dominação do material vindo das agências, influência capitalista, má preparação do jornalista, maniqueísmo na redação entre editores e repórteres) que, interligados, resultam no cenário objeto da dissertação, a solidão da América Latina. Portanto, não se pode creditar a culpa pela hegemonia de notícias do eixo Europa-EUA exclusivamente a uma única variável determinante e exterior aos próprios autores da relação jornalista-receptor.

\subsection{As falhas nos estudos sobre a comunicação}

A amostra pesquisada ${ }^{17}$ de trabalhos publicados sobre a comunicação na América Latina apresenta, em razão do contexto histórico-social em que foram produzidos, o foco em apenas um eixo de estudo. Os autores aqui citados estão corretos nas suas interpretações e merecem elogios por se debruçarem sobre a América Latina, tema muitas vezes esquecido pela Academia por não ter sido criado um pensamento latino-americano forte o suficiente para gerar muitos estudos.

Apesar desse quadro, a existência de autores como José Marques de Melo, Maria Nazareth Ferreira, Néstor García Canclini, Beatriz Sarlo, Jesús Martín-Barbero, entre outros que se dispuseram a empreender pesquisas da Comunicação na América Latina é digna de comemoração. Como se verá, o histórico enfraquecimento da noção de nação latinoamericana não só ocasiona a escassez de "cabeças" como possibilita o surgimento de intelectuais que não valorizam a história do continente.

Um dos primeiros estudiosos da comunicação na América Latina foi José Marques de Melo. Sua obra apresenta várias fases; a que mais interessa para esta pesquisa, Comunicação: Teoria e Política ${ }^{18}$ está profundamente influenciada pelo desejo de liberdade da época. O Brasil ainda vivia os últimos dias de uma ditadura militar de mais de

\footnotetext{
${ }^{17}$ Ver as referências bibliográficas

${ }^{18}$ MELO, José Marques de. Comunicação: Teoria e Política. São Paulo: Summus Editorial, 1985.
} 
vinte anos. Muitos países latino-americanos ainda estavam sob regimes ditatoriais. Seria quase impossível pensar estratégias de comunicação que não passassem pela consolidação do que autor chama de Comunicação Democrática.

Ao escrever essa obra, Melo sentia a necessidade de fortalecimento da sociedade civil nos países latino-americanos, via com simpatia o desenvolvimento do que ele chama de comunicação alternativa que poderia até desempenhar "um importante papel na arregimentação da sociedade civil" e lograria "quebrar o monopólio dos meios de comunicação hegemônica, controlados pelo Estado e acionados pela burguesia".

"Os meios de comunicação passaram a desempenhar o papel de multiplicadores da visão de mundo dos donos do poder, atualizando permanentemente a compreensão da realidade a partir dos interesses hegemônicos (...) O direito à comunicação, no sentido de acesso ao conhecimento, à informação, à opinião, constitui uma falácia em nossas sociedades latinoamericanas Pois as grandes maiorias estão excluídas das escola, onde não apreendem a base cultural indispensável ao exercício da cidadania. (..) $\mathrm{O}$ acesso dos cidadãos latinoamericanos ao mundo da política, da economia, da cultura, é fragmentado, atomizado, reduzido. Os programas de informação e de opinião ocupam espaços minúsculos nos veículos audiovisuais. (...) A imprensa latino-americana possui tiragens insignificantes, o que indica por um lado, o pauperismo econômico das grandes massas, que não podem adquirir tais produtos, mas significa também a sua recusa pela inacessibilidade do código escrito. (...) O Estado exerce o monopólio da comunicação e assegura a hegemonia burguesa sobre as nossas sociedades". ${ }^{19}$

Melo propõe uma luta para democratizar o acesso à comunicação e crê num fortalecimento da sociedade civil. É necessário compreender as condições de produção da obra: o texto foi escrito em 1984, antes, portanto da chegada definitiva do neoliberalismo e com as primeiras tentativas de eleições democráticas nos países da América Latina. Porém, muitos aspectos de como descreve a sociedade civil continuam presentes (uma sociedade enfraquecida e que ainda concentra a sua luta por condições básicas de desenvolvimento nos combates à violência, ao desemprego e à marginalização).

"Retomar a luta pela comunicação como um direito de todos, implica em mudar a fisionomia do Estado que aí está e dar-lhe uma nova feição, a de instância aberta à participação das maiorias excluídas. Pensar a comunicação como um direito de todos na sociedade configura uma luta, cujo resultado depende da mobilização, perseverança e combatividade da Sociedade Civil. E esse tem sido o grande obstáculo para lograr uma comunicação democrática na América Latina, porque nossas sociedades se constituíram, a partir do edifício colonial, em cima de estruturas cimentadas pelo Estado. (...) Comparado com as sociedades metropolitanas verificamos a fragilidade da Sociedade Civil na América Latina onde a Igreja, os sindicatos, os partidos políticos, as universidades ainda se ressentem de uma forte influência do Estado, em torno de que gravitam. Trata-se de um fenômeno que reproduz a estrutura do nosso capitalismo dependente ou tardio, onde o

\footnotetext{
${ }^{19}$ MELO, José Marques de. Idem p.12 -26
} 
Estado continua a ter o papel de superestrutura política que regula as relações de produção, atrelado ao aparato militar, que não é mero sustentáculo da burguesia, mas força decisiva articulada com o centro do poder multinacional. (...) Percebe-se que a Sociedade Civil começa a se fortalecer na América Latina. Mas a sua luta tem se concentrado no combate à violência, na resistência ao desemprego, à fome, à marginalização social. (...) Nessa luta, as instituições da sociedade civil lograram criar e desenvolver meios próprios de comunicação, em vista das barreiras e dos impedimentos de acesso aos meios de comunicação de massa. Criaram, portanto, canais de comunicação alternativa ou de comunicação popular, que têm florescido e esmaecido em função do próprio combate que realizam" ${ }^{20}$

O detalhe apontado por Melo - a criação de meios de comunicação próprios - é muito importante para o fortalecimento da sociedade civil. Porém, o aparecimento destes veículos que renovam a esperança da democratização dos meios de comunicação, de acesso à informação e de contemplação de toda a dinâmica da América Latina no noticiário é logo superado pela frustração do desaparecimento destes mesmos veículos. Cita-se, apenas como ilustração, o caso da revista Atenção!, que surgiu na segunda metade dos anos 90 como uma revista modelo de cobertura. Os jornalistas da Atenção! se pautavam por "não noticiar o que se chama hard news, mas, principalmente, as notícias que favorecem a luta dos movimentos sociais e denúncias dos ocasos do neoliberalismo na América Latina"21. Entre os exemplos estão as reportagens sobre a previdência privada no Chile, sobre o esquecimento (na época) dos prisioneiros políticos que seqüestraram o empresário brasileiro Abílio Diniz e que foram tratados como prisioneiros comuns. Apenas dez números foram publicados. A revista teve a curta duração de dois anos e sua publicação foi interrompida sem uma causa aparente. Sua história e o encerramento de suas atividades não ganharam estudos que mereciam.

O trabalho de Melo, em seguida, foi dedicado aos estudos da Pesquisa em Comunicação na América Latina, culminando com a Cátedra da Unesco para Pesquisa em Comunicação na América Latina. Na própria obra de 1985, Melo cita com entusiasmo outros organismos que congregam os pesquisadores da área de Comunicação na América Latina como a Federação Latino-Americana de Faculdades de Comunicação Social (FELAFACS), que apresenta propostas de democratização dos meios de comunicação. Infelizmente, o que

\footnotetext{
${ }^{20}$ Idem p.12-26

${ }^{21}$ DEPOIMENTO de José Sacchetta Ramos e Simone Biehler Mateos, editores da Atenção! a Alexandre Barbosa em 1996.
} 
se vê hoje na América Latina são poucas propostas de desenvolvimento dos meios de comunicação. O continente está debatendo os acordos da Área de Livre Comércio das Américas (ALCA) sem estabelecer informações precisas sobre a potencialidade dos meios de comunicação. Ao contrário, o que se percebe é a crise cada vez maior dos veículos de comunicação, que periodicamente demitem jornalistas e discutem as possibilidades de empréstimos governamentais para saldarem suas dívidas. Néstor García Canclini, no ensaio Latinoamericanos buscando lugar en este siglo, critica a atuação dos organismos de pesquisa em comunicação.

"Está pendente a tarefa dos organismos latino-americanos e interamericanos dedicados às Ciências Sociais e Humanidades. Não têm nada para dizer o Conselho Latinoamericano de Ciências Sociais (CLACSO), a Faculdade Latino-americana de Ciênciais Sociais (FLACSO), a Federação Latino-Americana de Faculdades de Comunicação Social (FELAFACS), a Associação de Estudos Latino-americanos (LASA) sobre as oportunidades e os riscos da competição pelas comunicações na América Latina entre Telefónica da Espanha e AT\&T, entre os bancos espanhóis e o Citybank?". ${ }^{22}$

Melo publicou muitos outros estudos, principalmente sobre a pesquisa em comunicação, valorizando outros autores que também se dedicaram ao tema. No entanto, para fins metodológicos serão destacados apenas os pontos do que pode ser chamada de fase inicial sobre os estudos brasileiros da Comunicação na América Latina.

O primeiro ponto é a presença de conceitos gramscinianos como "sociedade civil" e "hegemonia". A presença de Gramsci será muito forte na análise da Comunicação na América Latina, principalmente com o espanhol Jesús Martín-Barbero e o argentino Néstor García Canclini. O segundo ponto a ser destacado é a grande importância que Melo dá às organizações de estudo sobre a comunicação e que se tornariam a tônica de sua obra futura. Infelizmente, essas organizações estão muito distantes da realidade latino-americana e as discussões da academia ainda não reverteram os quadros e tão pouco apresentaram soluções de melhoria. Além do necessário debate em torno de discussões acadêmicas como a eterna pergunta: "O jornalismo é uma ciência ou uma ciência social aplicada?". As linhas de pesquisa de pós-graduação em Jornalismo não conseguem acompanhar o ritmo

${ }^{22}$ CANCLINI, Néstor García. Latinoamericanos buscando lugar en este siglo. Buenos Aires: Paidós, 2002. 
das mudanças impostas pelas evoluções tecnológicas e pelas novas condições das relações sociais.

Outros autores, posteriores a Marques de Melo, deram prosseguimento aos estudos sobre os processos de comunicação na América Latina. Foi um processo lento. A primeira etapa consistiu em comprovar cientificamente que a América Latina existe como categoria dentro das Ciências da Comunicação e é merecedora de investimentos em pesquisa. Em seguida foi necessário comprovar que, apesar de toda sua importância, a América Latina não tem espaço no jornalismo, fosse por meio da demonstração de que menos centímetros por coluna são dedicados às notícias latino-americanas, fosse pela análise do discurso. A terceira etapa foi encontrar as primeiras explicações para este cenário. Esta dissertação de mestrado está numa quarta etapa, que consiste em encontrar explicações para a ausência latino-americana do noticiário baseadas em dois eixos de estudo: o eixo 1, chamado de ambiente sócio-histórico-cultural, lança mão de conceitos originados no campo das Ciências Sociais, na História, na Política e na Economia e o eixo 2 utiliza conceitos originados no campo das Ciências da Comunicação, nas relações de trabalho dos jornalistas e no modo de produção jornalístico.

Uma grande militante na tarefa de denunciar a ausência da América Latina no noticiário é a professora da USP, Maria Nazareth Ferreira. Em diversos artigos e em dois livros $^{23}$ publicados pelo Centro Brasileiro de Estudos Latino-Americanos (CEBELA), Nazareth Ferreira, faz uma radiografia do que a imprensa publica sobre o continente. $O$ resultado mostrou que os brasileiros praticamente ignoram o fato de serem latinoamericanos. Em mais de 100 entrevistas realizadas em 15 cidades brasileiras, a pesquisa mostrou uma ausência quase total de conhecimentos sobre o continente.

Os "produtores de notícia", como Nazareth qualifica os jornalistas, também foram entrevistados. "A imagem da América Latina refletida nos meios de comunicação não valoriza suas qualidades, não interpreta sua realidade e não divulga a sua cultura. Depois

\footnotetext{
${ }^{23}$ FERREIRA, Maria Nazareth. A Comunicação (des) Integradora na América Latina: os contrastes do Neoliberalismo. São Paulo: Edicon: CEBELA, 1995.

FERREIRA, Maria Nazareth (org). América Latina, a Imagem de Um Continente na Escola e nos

Meios de Comunicação. São Paulo: CELACC: ECA, 1997.
} 
de entrevistar jornalistas responsáveis por jornais deste 'continente' político-cultural, concluise que, na maioria das vezes, a América Latina como um todo, como uma região definida, com seus problemas, seus fracassos e vitórias, com uma cultura múltipla, mas delimitada, não existe para sua imprensa". ${ }^{24}$

Para os editores dos jornais pesquisados, a "América Latina, enquanto região significativa do ponto de vista da notícia-mercadoria, é nula, pois quase todos os jornalistas confirmaram que ela não vende jornal". ${ }^{25}$ Espaços reduzidos, ausência de correspondentes e uso de do material das agências internacionais, sediadas nos EUA e na Europa são fatos comuns a todos os veículos. "Na leitura crítica dos jornais latino-americanos é visível a predominância de assuntos como escândalos, violência, catástrofes, (...). Geralmente os países - quando ocupam as páginas dos jornais - estão relacionados com notícias sensacionalistas." ${ }^{26}$ Entre os temas preferidos estão o narcotráfico, o futebol e os desastres naturais.

De acordo com a autora, as causas para esse cenário podem ser encontradas dentro do jornalismo. Nazareth Ferreira fez entrevistas com jornalistas dos principais veículos de comunicação impressa. A resposta foi quase sempre "isso não interessa ao meu público". "Como sabem o que é de interesse dos leitores?" pergunta Nazareth. "O que se sabe sobre o gosto do público, sobre a ideologia do público, tem sido usado como desculpa enganosa para encobrir uma política conservadora de manutenção das massas na sua inconsciência. (...) Qual seria o critério mais relevante para atender ao gosto do público? Seria veicular notícias de escândalos políticos, de desastres da natureza, de guerras civis, de crimes sensacionais, de sofrimento humano, criando a sensação de que o público está bem informado? Porque o que o público quer é também aquilo que lhe é sugerido". ${ }^{27}$

O trabalho de Nazareth comprova brilhantemente, por meio de dados concretos obtidos da leitura de jornais, de entrevistas com jornalistas, que a América Latina perde espaço para Europa e EUA no noticiário. A autora estabelece como causas dessa

\footnotetext{
${ }^{24}$ FERREIRA, Maria Nazareth. Op. Cit.

${ }^{25}$ FERREIRA, Maria Nazareth. Op. Cit.

${ }^{26}$ FERREIRA, Maria Nazareth. Op. Cit.

${ }^{27}$ FERREIRA, Maria Nazareth. Op. Cit, p 62.
} 
problemática a influência neoliberal e a ideologia capitalista das empresas detentoras dos veículos.

As condições impostas pelo neoliberalismo e a ideologia capitalista dos meios de comunicação também são fatores que explicam as falhas de cobertura internacional: regiões que não têm interesse comercial não são notícia. O jornalismo, como mecanismo de troca de informações, nasceu das notícias ligadas ao comércio. Onde havia trocas comerciais se estabelecia um veículo de comunicação. Houve também o uso destes veículos como canal de ideologias políticas, porém permaneceram vivos e cresceram os que souberam aliar a veiculação da ideologia com a obtenção de lucros por meio de anúncios. Essa essência é mantida até hoje. Da mesma forma que a periferia só é notícia no telejornal regional quando há algum fato sensacional, a América Latina só é notícia nos fatos espetaculares citados anteriormente pela professora Nazareth.

O imperialismo e o poder concentrado nos meios privados de produção - que se confundem com os meios de comunicação, pois as famílias proprietárias de grupos econômicos também são dos veículos de imprensa - são importantes para a compreensão da realidade latino-americana. Porém, essas relações comerciais e o imperialismo não são suficientes para explicar satisfatoriamente o espaço perdido da América Latina para os EUA e a Europa no noticiário.

De fato, o mercado define muitas regras dentro do universo capitalista neoliberal. Se determinado jornal tem entre seus acionistas anunciantes, empresas com interesses em determinadas regiões, é evidente que elas ganharão mais destaque e serão freqüentes alvos de análise. Porém, nem sempre isto ocorre.

O Afeganistão pode não ter interesse direto para nenhum acionista ou anunciante. Como explicar que durante a invasão dos norte-americanos, o país asiático não saía das manchetes? Vale a explicação de que a guerra é um acontecimento sensacional, que desperta o interesse do receptor. Este interesse dos brasileiros em observar a guerra num país distante e de hábitos diferentes vem reforçar que o público brasileiro não pertence a esse "mundo bárbaro" como foi pintado no jornalismo. Aqui entra novamente a definição do 
contrato: o público brasileiro se sente solidário do norte-americano na "cruzada contra o terrorismo" e consome as notícias sobre o Afeganistão para reafirmar esta posição. Fica claro, portanto, que não é só o caráter capitalista e a influência norte-americana que faz aumentar o espaço do noticiário ligado aos EUA. São fatores importantes, mas estão conciliados com as características da sociedade civil brasileira.

Entre as dissertações e teses de mestrado defendidas na Escola de Comunicação e Artes (ECA) da Universidade de São Paulo e na Especialização em Jornalismo Internacional da Pontifícia Universidade Católica de São Paulo e pesquisadas para este trabalho, a maioria se esforçou em provar - seja pela análise do discurso ou pela análise de conteúdo que a América Latina não tem espaço no noticiário brasileiro. No entanto, tal análise fica muito restrita à prova física. Feitos com régua e calculadora, estes textos pesquisados comprovam que os centímetros por coluna dedicados à América Latina são menores que os de outras regiões. É evidente que estes trabalhos são importantes e úteis, pois funcionam com um atestado dentro da corrente científica que exige a comprovação metodológica das teorias. Porém é necessário ir adiante e, além da comprovação das hipóteses, buscar as explicações mais imediatas para o fenômeno.

Um exemplo é a dissertação de mestrado de Marcelo José Abreu Lopes, Olhares sobre o Mundo, uma análise gráfica do jornal gaúcho Zero Hora que mostra que de 31 exemplares do jornal, totalizando 3.090 páginas, $2,3 \%$ do conteúdo foi dedicado ao noticiário internacional. Os assuntos mais freqüentes foram a queda do Airbus em Bahrein, seguido pelo Plano Colômbia, a Questão da Chechênia, Nazismo, Cumbre Sul-Americana, Eleições presidenciais norte-americanas. Os menos valorizados foram o processo contra Pinochet, o separatismo basco e a corrupção no Senado argentino. ${ }^{28}$

Outra linha de pesquisa no jornalismo é aquela feita pelos próprios jornalistas. Diante da crise econômica que atingiu os grandes veículos de comunicação também na década de 1990, alguns jornalistas deixaram as grandes redações e passaram a se dedicar à pesquisa

${ }^{28}$ LOPES, Marcelo José Abreu. Olhares sobre o mundo: valores na notícia da integração regional. 2001. Dissertação de Mestrado. Programa de Pós-Graduação em Comunicação. São Paulo, Universidade de São Paulo. 
acadêmica. São trabalhos que aliam as análises bibliográficas com experiências pessoais, por isso também são valiosos para compreender a construção do modo de produção jornalístico. Um dos exemplos é a obra do jornalista José Arbex, um dos primeiros dos que atuaram na grande imprensa a analisar criticamente a produção do Jornalismo. Em sua tese de doutorado, publicada na forma de livro pela Editora Casa Amarela ${ }^{29}$, Arbex admite que é a formação intelectual que permite ao jornalista ter diferenciais durante as coberturas, principalmente as internacionais.

O jornalista José Arbex narra a experiência pessoal de correspondente internacional e dedica um capítulo especial à América Latina. Nele, o autor reconhece que mesmo com a sólida formação acadêmica e preparação sobre a história dos países para os quais viajou, sentiu "que quase nada daquela experiência fora passada aos leitores e (...) começava a perceber que a mídia, mesmo quando relatasse acontecimentos reais, criava meras fabulações simplificadas, com o objetivo de oferecer aos leitores/telespectadores alguma sensação de ordem em relação a um mundo, de fato, complexo em demasia". ${ }^{30}$

O jornalista diz que, mesmo conhecendo razoavelmente a história da Nicarágua e de suas relações com os EUA, o processo de formação do movimento sandinista, seus princípios teóricos, as idéias dos vários grupos e os postulados da Teologia da Libertação, não conseguiu transmitir todas as sensações ao leitor. Por este raciocínio, menos ainda pode se esperar de uma cobertura feita apenas com colagens do material produzido pelas agências internacionais.

Ao analisar a cobertura internacional feita hoje, Arbex credita a falha mais à "inércia preconceituosa e ignorância intelectual [do jornalista] do que uma vontade política consciente. (...) É muito mais cômodo aceitar a cobertura feita pelas grandes agências de notícias e pelos veículos americanos do que investigar" o que de fato acontece, já que a mídia nacional adota uma postura "colonizada e provinciana". ${ }^{31}$ Dessa forma não é raro que

\footnotetext{
${ }^{29}$ ARBEX JR. José. Showrnalismo: a notícia como espetáculo. São Paulo, Editora Casa Amarela, 2001.

${ }^{30}$ Idem

${ }^{31}$ ARBEX JR., José. Op. Cit.
} 
uma cobertura jornalística se torne pobre, que faça parte do consenso, pois é muito mais fácil sustentar um preconceito do que destruí-lo. 
Uma das graves conseqüências da pauta da mídia latino-americana pelos despachos das agências internacionais e reportagens do New York Times, Washington Post e The Economist é que ela (pauta) adquire um "caráter normativo" ou seja, "Se a imprensa diz que alguma coisa é verdadeira, isto se impõe como verdade, mesmo que seja falso. 0 receptor não possui outros critérios de avaliação, pois, como não tem experiência concreta do acontecimento, só pode orientar-se confrontando os diferentes meios de comunicação uns com os outros. E se todos dizem a mesma coisa, é obrigado a admitir que é a versão correta dos fatos, a notícia 'verdade oficial'”. ${ }^{32}$

Quando o assunto é América Latina, o caso é mais grave. Durante as pesquisas Arbex constatou que na mídia há um "deserto de informação sobre a vida nacional dos povos, em benefício da notícia que privilegia o jogo das potências políticas e econômicas (...) os países latino-americanos simplesmente não interessam. A 'globalização' apenas acentuou o quadro de distanciamento cultural, intelectual presentes entre a elite e a nação em toda a América Latina. Uma das coisas que mais me abalaram foi saber que certas notícias serão censuradas ou descartadas não por afetaram interesses políticos ou econômicos, mas simplesmente serão consideradas desinteressantes a priori, mesmo se fascinantes. Serão descartadas por um processo de pura exclusão cultural" ${ }^{33}$

O que diferenciaria uma reportagem "morna" de uma "arrojada" seria o grau de preparação do jornalista, que percorre o caminho da formação pessoal e não o da exclusiva produção de notícias. "Podem-se publicar centenas de páginas sobre a Nicarágua sem nada informar de realmente significativo ou podem-se publicar poucos parágrafos, descrever uma pequena cena do cotidiano que abra a possibilidade de múltiplas indagações. O problema é desmontar as narrativas permitindo o surgimento de vozes que permaneceriam ocultas e esquecidas" ${ }^{34}$

Dessa forma, o jornalista teria subsídios para compreender melhor o continente em que vive e atuar para interpretar mais tranqüilamente acontecimentos como o governo Hugo

\footnotetext{
${ }^{32}$ RAMONET, Ignacio. A Tirania da Comunicação; tradução de Lúcia Mathilde Endlich Orth, Petrópolis, RJ: Vozes, 1999.

${ }^{33}$ ARBEX JR, José. Showrnalismo. Op. Cit.

${ }^{34}$ ARBEX JR, José. Op. Cit.
} 
Chávez, na Venezuela, as lutas contra o neoliberalismo na Argentina, o processo de eleição no Equador, a importância simbólica para o continente que representou a eleição de Lula no Brasil, os movimentos de luta pela terra (Via Campesina e MST), os zapatistas no sul do México, entre outros.

Interessante notar que, segundo Arbex, mesmo com o grande preparo intelectual, a totalidade da a complexidade da experiência da cobertura na Nicarágua deixou de ser transmitida aos leitores. Ora, se ele afirma que o jornalista precisa criar um repertório cultural por meio da formação pessoal e que, mesmo com todo o seu repertório sobre a Nicarágua, nem todas as sensações foram transmitidas ao leitor é porque há mais fatores que contribuem para criar a distância entre os receptores e a América Latina.

Neste caso, faltou levar em consideração alguns aspectos presentes no eixo 2 (as relações de trabalho na redação e o modo de produção jornalístico) e alguns aspectos do eixo 1 (os óculos dos leitores) para compreender melhor as causas dessa falha na comunicação. Exemplificando, não basta que o jornalista (no caso o repórter) tenha o repertório cultural suficiente para a "confecção" de uma reportagem bem feita sobre a Nicarágua. É sabido que no modo de produção jornalístico, o texto da reportagem passa por um processo, tal qual uma matéria-prima numa fábrica. A reportagem redigida é passada para o editor, que decide a hierarquia da notícia dentro da página e instrui o diagramador de como deve ser distribuído o texto, se há espaço para fotos, etc. Essa definição é feita em "conjunto" com o departamento comercial, que, geralmente, vende o espaço para os anunciantes, antes do fechamento do jornal. É o anunciante quem determina o tamanho do anúncio, em que página deve ser inserido e em qual local, escolhendo uma das opções da tabela de anúncios.

Se o editor não tiver o mesmo repertório cultural do repórter, ele não verá a reportagem com a mesma importância de seu redator. Para ele, cortar determinado trecho do texto, alterar o título ou subtrair a foto para que haja espaço suficiente que comporte os anúncios não será uma tarefa desgastante. Fica claro, portanto, como as regras da empresa jornalística capitalista (que sobrevive de anúncios), a hierarquia dentro da redação e o 
despreparo intelectual de outras camadas dentro da escala de produção também interferem no processo de Comunicação.

Caso o editor tenha consciência da importância das notícias sobre a Nicarágua ele pode até "brigar" com as exigências do departamento comercial e firmar posição para que a matéria seja publicada no espaço e com os recursos necessários. No entanto, ele não terá argumentos diante do diretor do Jornal se este ordenar que a matéria deva ser reduzida para comportar o anúncio. O argumento da direção será "isto não interessa ao público".

Aqui entra uma das categorias do eixo 1. O público de fato, não se interessa pela Nicarágua. Porém, o público, no caso citado pelo diretor da redação não corresponde à totalidade dos leitores latino-americanos, mas apenas aqueles que são consumidores em potencial dos produtos anunciados naquele meio de comunicação. E estes consumidores pertencem à nação latino-americana que não se sente latino-americana.

Como já foi dito, para esses consumidores, o jornalismo serve como manual de civilidade. Esses consumidores pedem notícias que os coloquem em contato com o mundo desenvolvido. O interesse pelo "resto do mundo" se restringe aos fatos espetaculares: guerras, desastres naturais, etc, que apenas reforçam a condição de serem externos a esta condição de sofrimento. Assim, o interesse pela Nicarágua iria até o ponto de retratar a guerra.

Qualquer informação a mais seria interessante apenas para a faixa de público que busca informações sobre as causas e conseqüências dos acontecimentos do mundo. Essa faixa de público é pequena justamente, por outra categoria: a falta de estudos que tenham como bibliografia indicada pensadores latino-americanos. A histórica falta de incentivo à leitura sobre a América Latina não forma gerações de públicos interessados em estudar profundamente os conflitos da região.

Sobra, assim, apenas o grande público da nação burguesa, munido de óculos preconceituosos que enxergam a Nicarágua como mais um país de uma região confusa, de Geografia indefinida e que não pertence ao "mundo civilizado". Portanto, são sempre os dois 
eixos de explicação que devem ser aplicados para se obterem explicações mais precisas sobre os fenômenos de Comunicação no continente e nunca fatores isolados.

As análises de Nazareth e de Arbex conciliam na discussão os estudos das Ciências Sociais com a visão do jornalista profissional, sujeito das relações de trabalho nas redações.

\subsection{Os eixos de análise}

A tese desta dissertação é que a interpretação da Comunicação na América Latina não pode estar nem somente nas teorias dedutivistas nem exclusivamente nas indutivistas. Há um conjunto complexo de fatores que interagem para montar o cenário em que o jornalismo se manifesta. Em um eixo de análise, a hegemonia, caracterizada pela influência norte-americana, pela ideologia capitalista dos meios de comunicação e a história das lutas sociais. No outro eixo, o jornalista despreparado intelectualmente e explorado nas redações. Como analisou Canclini, nossos próprios mecanismos de estudos sociais e comunicacionais (órgãos de pesquisa, intelectuais e estudantes) parecem aceitar essa condição de subalterno e enxergam como "desenvolvido" apenas o que é gerado pelos setores hegemônicos. O autor afirma que

"na América Latina se escutam litúrgicas lamentações sobre a americanização da linguagem e do consumo, mas contamos com apenas três ou quatro economistas da cultura que estudam a articulação dos negócios globalizados com a produção simbólica. Não temos mais que quatro ou cinco grupos de estudos sobre a difusão da música, do cinema, da televisão e da literatura na sociedade estadunidense. Salvo que se reoriente a ação das universidades e dos governos, chegaremos com tanta pouca informação sobre a potencialidade de nossos recursos culturais e comunicacionais nas reuniões da ALCA em 2005 como quando o México assinou os tratados do NAFTA. (...) Assim como não sairemos do subdesenvolvimento sem aumentos substanciais nos investimentos em Ciência e Tecnologia, não podemos esperar que as vozes e imagens do latinoamericano sejam outras que não as do realismo mágico difundido pelas editoras européias e nossa decomposição social filmada nos noticiários da CNN ou nos filmes hollywoodianos sobre narcotraficantes se não modificamos a articulação das investigações culturais, políticas culturais e comunicacionais. "35

Os argumentos que comprovam a hipótese de que existe um conjunto complexo de fatores que interagem para montar o cenário de solidão da América Latina no jornalismo estão sedimentados em dois eixos de estudo que, freqüentemente, se interligam, gerando uma intersecção onde se produz a comunicação jornalística que é objeto desta pesquisa.

\footnotetext{
${ }^{35}$ CANCLINI, Néstor García. Latinoamericanos buscando lugar em este siglo. Op. Cit. p. 55-7.
} 
Esses dois eixos de raciocínio partem do pressuposto de que o jornalismo não é uma produção artificial. Ele é conseqüência da história da sociedade; é resultado do "olhar" dessa sociedade perante seus integrantes e para os integrantes de outras sociedades. Também é resultado da produção intelectual do jornalista, da sua visão, de sua formação, de suas disposições e de sua lógica da profissão. Finalmente, o jornalismo reflete a ideologia das empresas que detêm os veículos de comunicação, as quais estão inseridas no modo de produção capitalista, que, por sua vez, está apoiado em conceitos neoliberais. A partir desta afirmação, os dois eixos que compõem o quadro teórico de referência são: eixo

1: ambiente sócio-histórico-cultural e eixo 2: o jornalista: formação, produção e relações de trabalho.

Foi feita a divisão em dois eixos porque são raras as obras que façam a interface destes dois planos na produção jornalística. É importante ressaltar que é justamente a sobreposição destes dois eixos que consegue explicar a ausência da América Latina do noticiário brasileiro.

Assim como não cabe apenas a interpretação dedutivista ou apenas a indutivista para compreender a relação entre o continente latino-americano e o jornalismo, também não se pode querer compreender todo este cenário baseando-se apenas na obra de um autor, ou em um único campo do conhecimento. Qualquer bibliografia sobre o jornalismo na América Latina deve se valer de interpretações originadas no campo das Ciências da Comunicação, das Ciências Sociais, da História e da Economia. É na intersecção desses campos, aqui ilustrada nesta dissertação nos dois eixos de pesquisa, que o problema encontra respostas mais satisfatórias.

Vale lembrar que isto não quer dizer que os autores confrontados aqui sejam exclusivamente dedutivos ou indutivos. Suas obras são muito complexas e de grande importância e qualquer rótulo seria precipitado e até leviano. O importante é frisar que futuros estudantes e leitores deste tema não poderão compreender toda a gama de causas da solidão da América Latina apenas lendo um autor, seja ela do brilhantismo que for. Ao se estudar a relação América Latina-Jornalismo, se a bibliografia contiver apenas 
comunicólogos ou profissionais do campo do jornalismo, pode-se deixar de fora conceitos importantes originados no campo das Ciências Sociais, como se verá adiante. Da mesma forma, apoiar-se apenas em sociólogos ou historiadores pode deixar de lado questões ligadas às relações de trabalho, às características das empresas capitalistas e ao modo de produção jornalístico. Todos esses autores também não podem esquecer da influência da Economia no jornalismo.

A leitura dessa dissertação, portanto, deve ser feita com olhos de cientistas sociais, de comunicólogos e de jornalistas como José Arbex e Ignacio Ramonet, nunca se esquecendo de que a interpretação para o isolamento da América Latina não está apenas na ausência da criação de veículos ligados aos movimentos populares e nem apenas na influência do capitalismo sobre o jornalismo. Essa interface entre as Ciências Sociais e o Jornalismo é fundamental para ler esta dissertação e proceder à análise do objeto de estudo.

O sociólogo francês Pierre Bourdieu, aliás, vê com desconfiança ${ }^{36}$ a tendência de alguns jornalistas se proclamarem intelectuais e se prestarem a fazer análises da política, da sociedade e da economia. Essa força emprestada aos jornalistas e legitimada pela sociedade civil é muito contundente. Bourdieu faz um brilhante panorama de como os jornalistas ditam o que deve ser notícia, o que deve ser estudado e o que merece ter atenção. Ele define algumas categorias importantes para a compreensão do objeto de estudo:

Assuntos-ônibus. De acordo com Bourdieu são assuntos que não chocam a ninguém, que interessam a todo mundo. Não envolvem disputa, não dividem, que formam consenso, mas que não toquem em nada de importante. São as chamadas notícias de variedades e pode-se incluir o esporte entre elas. O noticiário está carregado deles. O tempo (ou o espaço) é vital no jornalismo. Portanto, se tempo e espaço tão preciosos são preenchidos com temas tão vazios é porque estas futilidades ocultam "coisas preciosas". O tempo gasto nos assuntos-ônibus poderia ser empregado para noticiar outros assuntos.

\footnotetext{
${ }^{3636}$ BOURDIEU, Pierre. Sobre a Televisão. Seguido de A influência do jornalismo e Os Jogos Olímpicos. Tradução de Maria Lúcia Machado. Rio de Janeiro: Jorge Zahar Editor, 1997.
} 
Óculos dos jornalistas. No documentário brasileiro "Janela da Alma"37, diversas pessoas que têm deficiências visuais são convidadas para explicar a forma como "enxergam" o mundo. Dentre os depoimentos, o diretor de cinema Win Wenders afirma que seus óculos são como uma moldura do mundo, ou seja, tudo o que ele vê, é enquadrado por essa moldura. Da mesma maneira os jornalistas vêem o mundo. Para Bourdieu os jornalistas, condicionados pelas propensões inerentes à profissão, por sua visão de mundo, por sua formação, pela lógica da profissão, pela influência capitalista, pela imposição do mercado de trabalho e por suas próprias disposições, selecionam na realidade algo que lhes pareça particular em função de categorias de percepção. ${ }^{38}$

${ }_{37}$ JANELA DA ALMA. Dir. João Jardim e Walter Carvalho. Brasil, Copacabana Filmes, 73 min, 2002.

${ }^{38}$ A teoria dos óculos dos jornalistas é detalhada no Capítulo III desta dissertação. 
Para explicar estas categorias - estruturas que organizam o percebido, determinando o que se vê e o que não se vê - é usada a metáfora dos óculos. "Os jornalistas têm óculos especiais a partir dos quais vêem certas coisas e não outras; e vêem de certa maneira as coisas que vêem. Eles operam uma seleção e uma construção do que é selecionado". Aqui acrescento que os óculos são formados não só pela lógica da profissão e pela formação das notícias, mas também por todos os outros fatores descritos anteriormente e que fazem parte dos dois eixos de estudo: a História, o contrato com o leitor e, com grande força sobre as demais, as relações de trabalho nas redações.

Circulação circular da informação. Bourdieu pede para o leitor fazer um teste: observar as capas dos jornais durante 15 dias e perceber que são quase iguais. Os jornais passam boa parte do tempo citando-se uns aos outros e o acirramento da concorrência faz com que se pautem mutuamente. Outros estudiosos chamam esse processo de pauta consensual ou auto-referencialidade:

Também na imprensa escrita há sintomas claros desta auto-referencialidade comunicativa, no fato de os jornais construírem as notícias de fatos absolutamente extrajornalísticos ou não-jornalísticos, no fato de fazerem matérias ou séries de matérias sobre si mesmos, olhando-se como espelhos narcísicos, passando para o público algo que só teria a ver com a economia interna de cada empresa. [...] Em última análise, está-se girando em torno das mesmas coisas e a redação do jornal torna-se a matriz originária dessa fantástica indústria de ficções. ${ }^{39}$

Para Bourdieu, a informação que chega ao receptor é homogeneizada, pois todos os veículos de comunicação sofrem as mesmas restrições, são orientados pelas mesmas pesquisas de opinião e audiência e têm os mesmos anunciantes. Os jornalistas se informam com outros jornalistas. O que é notícia na TV deve, quase obrigatoriamente, ser notícia no rádio, no jornal, no semanário, na Internet, pois um veículo não pode deixar de noticiar o que outro noticiou.

Censura. Esta circulação circular da informação, gerada por jornalistas que já selecionam as notícias a partir de óculos, ou seja, de categorias de pensamento que definem o que deve ser notícia produz uma censura. Para Bourdieu não há discurso ou ação

\footnotetext{
${ }^{39}$ MARCONDES FILHO, Ciro. Jornalismo Fin-de-siécle. São Paulo: Scritta Editorial, 1993, p 103108.
} 
que não se submeta a essa prova de seleção jornalística, a essa censura que os jornalistas - em especial os que assumem o cargo de editores - exercem, muitas vezes sem tomarem noção disto. A censura dos jornalistas é feita ao "reter apenas o que é capaz de lhes interessar, de 'prender sua atenção', isto é, de entrar em suas categorias, em sua grade, e ao relegar à insignificância ou à indiferença expressões simbólicas que mereceriam atingir o conjunto dos cidadãos". ${ }^{40}$ Em resumo o que é capaz de vender jornal, de atrair a maior parcela possível do público leitor, argumento precioso para maiores verbas publicitárias, combustível da grande imprensa.

É esta censura que sofre a América Latina.

Distância. Outra categoria que é importante para entender esta censura da América Latina é a distância. Em geral, quando se fala em jornalismo, o termo distância é usualmente aplicado para explicar a relação do jornalista com o objeto da notícia. Para a formação desta categoria usei conceitos lidos não apenas nos autores que tratam a comunicação, mas também na bibliografia sobre a história da América Latina. Ao se estudar a história do ponto de vista marxista há, também na América Latina, uma luta de classes entre as elites e os setores populares. A estes sempre foi condenada qualquer forma de manifestação ou revolução da ordem política, social e econômica. Na América Latina as classes populares somam mais de 500 anos de solidão, ou seja, em toda a vez que algum movimento social alcançou determinado êxito em suas ações, a repressão das elites foi dura como forma de dar "exemplos" que intimidassem novas tentativas, como aconteceu, por exemplo, com Palmares e Canudos

A distância do jornalista da grande imprensa à América Latina é maior do que a distância aplicada a outros "objetos" de pauta. A distância do jornalista de grande imprensa para a América Latina tem a mesma força da distância das elites sobre os movimentos populares. Quando se lê a história das lutas sociais ${ }^{41}$ no continente, é de entristecer ver o desprezo das elites nacionais em relação à devastação dos recursos minerais, naturais e

\footnotetext{
${ }^{40}$ BOURDIEU, Pierre. Op. Cit. p 67.

${ }^{41}$ GALEANO, Eduardo. As Veias Abertas da América Latina, 14 ed., Rio de Janeiro, Paz e Terra, 1982.
} 
humanos pelas empresas multinacionais como a United Fruit. A grande imprensa brasileira vê com desdém o sofrimento de índios bolivianos e o subdesenvolvimento do Paraguai, reforçando preconceitos históricos, principalmente nas transmissões esportivas, sem se dar conta de que o estado de pobreza e atraso destas nações tem causas históricas e, muitas vezes, até a participação brasileira, como no Paraguai.

O distanciamento dos jornalistas em relação a América Latina contribui também para a censura e tem origem tanto no processo histórico - é típico da história latino-americana distanciar-se dos problemas e das temáticas dos camponeses e operários - quanto no processo de configuração das categorias de pensamento (os óculos) de receptores e jornalistas, descrito anteriormente. Os jornalistas exercem o jornalismo que consideram adequado para seus leitores, e nesta adequação não se encaixa a América Latina.

Quando Bourdieu afirma que ações ou discursos merecem atingir o conjunto dos cidadãos está colocando uma visão particular do que ele considera um jornalismo ideal. Para usar uma categoria de Gramsci, seria o Jornalismo Integral. Na obra Os Intelectuais e a Organização da Cultura, Gramsci define como Jornalismo Integral aquele que pretende satisfazer todas as necessidades de seu público, mas pretende também criar e desenvolver essas necessidades e, conseqüentemente, criar seu público e ampliar progressivamente sua área ${ }^{42}$. O que a grande imprensa faz é criar o público do que essa dissertação chama de América Latina Oficial (burguesa, elitista e branca), desprezando a América Latina Popular.

Por um lado os jornalistas se pautam em outros jornalistas e a disputa pelo índice de audiência provoca o canibalismo dentro do campo jornalístico, por outro os jornalistas são legitimados pelos seus receptores, lembrando que estes são pertencentes ao campo "oficial" da América Latina: burguês, preconceituoso e dominante. Quando um jornalista diz que determinado assunto "não interessa ao público", na verdade, está lançando mão de um contrato estabelecido com seu receptor (consumidor), que "aceita" as categorias escolhidas pelo jornalista como sendo também as dele, pois essas categorias são o manual de urbanidade que indica como se vestir, comer e expressar os sentimentos na cidade. Ou

\footnotetext{
${ }^{42}$ GRAMSCI, Antonio. Os Intelectuais e a Formação da Cultura. 9a ed.Rio de Janeiro: Civilização Brasileira, 1995. p.161.
} 
seja, o leitor/ouvinte/telespectador da América Latina Oficial usa os mesmos óculos dos jornalistas pertencentes aos meios de comunicação ligados a essa América Latina.

Isso acontece porque as categorias que formatam esses óculos não são simplesmente dominadoras e coercitivas, mas, usando outro termo de Gramsci, hegemônicas. A hegemonia se estabelece pelo poder econômico, político e de coerção das classes detentoras dos meios de produção e é reforçada ideologicamente quando há vínculo entre os meios de comunicação e a classe dominante, ou seja, numa aliança na qual meios de comunicação e dominadores contratam entre si prestações recíprocas. Os jornalistas funcionam como "comissários do grupo dominante para o exercício das funções subalternas da hegemonia social e do governo político". ${ }^{43}$ Essa relação de troca que se estabelece dentro da América Latina Oficial é descrita desta forma por Ciro Marcondes Fillho:

\begin{abstract}
"Existe, sem sombra de dúvidas, uma relação forte, vibrante, intensa entre a emissão e a recepção por parte do indivíduo. [...] constata-se que o tipo de relação entre receptor e produtor da comunicação em massa é a de troca. As empresas de comunicação oferecem produtos e em troca esperam obter audiência (a audiência, assim como a venda de publicidade, são valores de troca que a empresa de comunicação dispõe para aumentar seu capital e gerar lucros [...]. O receptor assiste ao programa de televisão (a audiência é a 'moeda' de que se usa para pagar o programa) e espera, com isso, obter um produto. [...] Nenhum produto de comunicação agrada se for feito exclusivamente com critérios de interesse dos que controlam a difusão de informação e comunicação em massa. Sem troca não há consenso, sem consenso não se cria a audiência. Dito de forma simbólica, sem moeda não há troca, nem equivalência nem a sustentação ideológica. Portanto, nem comunicação." ${ }^{\prime 4}$
\end{abstract}

Ciro Marcondes procura mostrar, neste texto, que há uma "massa" que apóia os movimentos das elites em determinados países, ao citar os golpes militares no Brasil e no Chile como exemplos. Esta "massa" pode ser interpretada como a América Latina Oficial.

De acordo com a hipótese deste trabalho, essas categorias, os óculos dos jornalistas, são formadas pela interligação de fatores tanto do campo histórico-cultural (eixo 1) como do campo do jornalismo (Eixo 2). Dentro do campo da América Latina Oficial, pelo fato de jornalistas e receptores usarem os mesmos óculos o consenso se estabelece e a linguagem do jornalismo praticado pela América Latina Oficial se torna

\footnotetext{
${ }^{43}$ GRAMSCI, Antonio. Os Intelectuais e a Organização da Cultura. 9a ed. Rio de Janeiro: Civilização Brasileira, 1995, p 11.

${ }^{44}$ MARCONDES FILHO, Ciro. Quem manipula quem?: poder e massas na indústria da cultura e da comunicação no Brasil. Petrópolis: Vozes, 1986. p. 27-29.
} 
hegemônica. Por usarem os mesmos óculos, receptores da América Latina Oficial e jornalistas de grande imprensa se distanciam da América Latina e apenas notícias relacionadas aos EUA ou à Europa merecem destaque.

\section{Eixo 1: ambiente histórico-cultural}

Os óculos dos jornalistas foram forjados ao longo da História da América Latina. O processo histórico de formação das nações latino-americanas foi decisivo para o estabelecimento das sociedades civis enfraquecidas nestas nações. Sociedades civis enfraquecidas são mais facilmente dominadas pelas forças hegemônicas. Essas forças hegemônicas (que podem ser o Estado, a Igreja, os latifundiários, a burguesia nacional ou os representantes de interesses estrangeiros, que muitas vezes são aliados da burguesia nacional) conseguem estabelecer mais facilmente a censura dos meios de comunicação, ou seja, o que se deve informar e o que não se deve informar.

Para traçar qual foi esse processo histórico esta dissertação se baseou em autores como Túlio H. Donghi, para situar cronologicamente os fatos da História e José Carlos Mariátegui, que definiu as nações latino-americanas como "incompletamente formadas", ou seja, apesar dos processos de independência política das metrópoles, os Estados formados no século XIX não alteraram a estrutura de poder. Continuaram dependentes economicamente de outras nações, não absorveram a mão-de-obra escrava liberta, não levaram ao cabo o processo de Reforma Agrária e não tiraram o poder político da aristocracia associada ao capital estrangeiro.

Nesta linha também contribuem as obras de autores como Eduardo Galeano, Darcy Ribeiro, Michel Löwy e Emir Sader, estes últimos mostrando como foram frustradas as tentativas de transformação das sociedades latino-americanas. Em mais de 500 anos de História, todas as tentativas populares de construção da história foram massacradas violentamente. A conseqüência desses massacres na comunicação é a perpetuação da história dos vencedores, legitimada pelo jornalismo, em detrimento da história dos vencidos. 
Esse processo de formação interrompido formou Estados subalternos às potências estrangeiras, primeiro à Inglaterra e à França, em seguida aos Estados Unidos. Quando não se usava a força, como no caso da invasão da Nicarágua pelas tropas norte-americanas, se empregava a coerção pela dominação cultural ou pela cooptação da burguesia nacional para os interesses das potências. A cooptação e dominação cultural têm efeitos diretos na produção jornalística, já que os veículos de comunicação são de propriedade da burguesia, muitas vezes associada ao capital estrangeiro e, por isso, porta-voz de seus interesses. Para a análise da formação do conceito de América Latina - e todas as nações que se formam a partir desta questão - foi fundamental a leitura de Octavio lanni, Francisco de Oliveira, Darcy Ribeiro, Juan Comas e Dante Moreira Leite. Os dois últimos, em contínuo diálogo com lanni, também contribuíram para o entendimento das relações de aceitação, ou não, das diferentes nações latino-americanas.

Sobre a relação EUA-América Latina há autores que mostram como ela foi praticada de maneira violenta. Marta Huggins ${ }^{45}$, descreve como os EUA controlaram as manifestações populares e de esquerda na América Latina. Jon Lee Anderson, na biografia de Che Guevara, descreve as invasões da Guatemala, de Cuba e o financiamento da caçada a Guevara pelo Estado norte-americano, além das relações íntimas entre a United Fruit Co. com os burocratas do Departamento de Estado.

O interessante dessa relação EUA-América Latina, conhecida como imperialismo, é a forma como o jornalismo a retratava: a dominação pela força praticada pelos EUA não era vista desta maneira pela imprensa, principalmente brasileira. Depois da II Guerra Mundial, os brasileiros enxergavam nos EUA um modelo a ser seguido e não uma nação de interesses escusos. Antônio Pedro Tota ${ }^{46}$ faz um estudo de como aconteceu a americanização do Brasil.

Interessados em fazer do Brasil um aliado contra o Eixo e, desta forma, deter o avanço nazista no Atlântico, os EUA usaram de todos os recursos para seduzir corações e mentes dos brasileiros. Os planos elaborados pela agência criada pelo magnata norte-

\footnotetext{
${ }^{45}$ HUGGINS, Marta. Polícia e Política: relações EUA/América Latina.São Paulo, Cortez, 1998.

${ }^{46}$ TOTA, Antonio Pedro. Op. Cit.
} 
americano Nelson Rockefeller envolviam o uso dos meios de comunicação - principalmente o rádio e a TV, mas também revistas e jornais - para estreitar a relação entre os EUA e o Brasil. A agência de Rockefeller organizou um bombardeio ideológico na América Latina, divulgando por meio do rádio, do cinema e das revistas um mudo de progresso por meio de bugigangas como eletrodomésticos. Foi implantado, de maneira sedutora, o hoje famoso american way of life.

Outra conseqüência deste processo de sedução ideológica, que não está no livro de Tota mas que é fundamental para a ausência da América Latina do noticiário, é que esse bombardeio ideológico foi simultâneo ao desenvolvimento dos meios de comunicação no Brasil. Ao mesmo tempo em que surgiam emissoras de rádio, que se formavam os profissionais que nelas trabalhavam e que o cinema ia se implantando no cotidiano brasileiro, desembarcavam no país as produções feitas nos EUA, por profissionais norteamericanos, exclusivamente para o público brasileiro. Assim, foi quase natural que o jornalismo que ia se fortalecendo no Brasil pelo rádio ou pelo cinema, fosse formatado e copiado do modelo norte-americano. Pode-se afirmar que a forma de jornalismo praticada hoje no Brasil nasceu durante o processo de americanização. Esse fato pode ser comprovado pelo uso de jargões em inglês como lead, teaser, replay, copydesk, etc. Portanto, não é de se estranhar que o jornalismo brasileiro se paute tanto pelo jornalismo norte-americano. Não é só pelo fato dos EUA serem o centro econômico do mundo, mas porque o jornalismo brasileiro cresceu copiando o modelo norte-americano.

Esse é o quadro histórico. Porém, é necessário explicar neste campo como este processos operam no olhar do leitor/ouvinte/telespectador. Os autores usados para explicar essa situação são Néstor García Canclini e Beatriz Sarlo. Ambos utilizam como referência as obras de Jesús Martín-Barbero e os escritos de Gramsci.

Além das análises já descritas aqui, Canclini também aponta outros fatores para a solidão da América Latina. O primeiro deles é que a burguesia e parte da intelectualidade (onde também se insere a imprensa) latino-americana não querem ser latino-americanas. 
No ensaio Latinoamericanos buscando lugar en este siglo ${ }^{47}$, além de criticar as políticas governamentais que não se preocupam com a produção cultural e de comunicação das nações latino-americanas, o autor critica o fato da América Latina não ser estudada nos diversos níveis de ensino e mostra como ruiu o significado de nação.

Nessa mesma linha, a resposta à indagação de como pode existir isolamento em tempos de globalização é dada por Beatriz Sarlo ${ }^{48}$. A intelectual argentina explica que a globalização que se opera é a de mercados e não de países. Portanto, o que não interessa ao mercado está longe de ser globalizado. Em outras palavras, o que o mercado não globaliza não entra nas manchetes dos jornais e está condenado ao esquecimento.

Uma categoria definida por Sarlo que ilustra o cotidiano das nações latinoamericanas é a de cidades degradadas. Os não-lugares (shoppings) ditam o cotidiano das pessoas, destruindo a noção de cidade e de público e incentivando o consumo e a idéia de sucesso individual. Como conseqüência, as cidades estão degradadas, os centros estão degradados e o espaço público, a praça, os passeios somem da paisagem urbana aumentando o individualismo. Portanto, a noção de "pertencimento" à América Latina nas grandes metrópoles, já historicamente enfraquecida, fica ainda mais debilitada com esse cenário de degradação e de substituição do centro político por um centro comercial. Sindicatos, partidos políticos, intelectuais, escolas e universidades perdem seus valores e são substituídos, ou pelo mercado, ou pela mídia.

\section{Eixo 2: Jornalistas: produções e relações de trabalho}

Os autores adotados para esta dissertação interpretam de diferentes formas o mundo dos jornalistas. Uma delas credita as deficiências da produção jornalística diretamente à falhas dos próprios jornalistas e às influências do campo em que atuam. Outra interpretação é aquela que reconhece as falhas dos jornalistas, mas justifica essa culpa pelas peculiaridades da profissão. Há ainda a dificuldade das novas gerações dos

${ }^{47}$ CANCLINI, Néstor García. Latinoamericanos buscando lugar en este siglo, Buenos Aires:

Paidós, 2002

${ }^{48}$ SARLO, Beatriz. Cenas da Vida Pós-Moderna. Rio de Janeiro: Editora UFRJ, 1997. 
jornalistas, formados em grande quantidade pelas faculdades que se multiplicaram no país (de acordo com o Ministério da Educação em 2003, 221 cursos espalhados pelo Brasil descarregaram no mercado mais de 6.983 novos diplomados) $)^{49}$. Na ansiedade de entrar no mercado, estes novos jornalistas aceitam funções que se confundem com publicitários ou relações públicas. Para aumentar o rendimento trabalham em empresas diferentes, sendo jornalista em uma delas e relações públicas em outra.

Por falhas dos jornalistas pode-se citar o despreparo e até ignorância intelectual, a despolitização, o pouco tempo dedicado aos estudos e a submissão aos manuais de redação e à ideologia das empresas que condicionam o uso de categorias de pensamento para selecionar no cotidiano o que deve ser notícia. As influências do campo jornalístico são a ideologia capitalista das empresas detentoras dos veículos de comunicação, a pauta consensual, a circulação circular de informação, a obsessão pelas notícias em tempo real, a concorrência pelo índice de audiência e disputa por anunciantes. Essa linha é representada por autores como José Arbex, Ignácio Ramonet, Maria Nazareth Ferreira e Pierre Bourdieu.

As idéias de Arbex, Bourdieu e Nazareth já foram apresentadas. Falta apresentar Ignacio Ramonet que é diretor do jornal francês Le Monde Diplomatique, que também se dedica a estudar e a criticar a produção da grande imprensa. Na obra A Tirania da Comunicação, ele criticou diversos erros de cobertura da imprensa internacional e já apontava, em 1999, uma crise da imprensa, que se intensifica a cada ano.

Há ainda um detalhe a ser anotado e que não foi totalmente trabalhado e elucidado na literatura sobre o assunto. Em entrevista concedia ao autor desta dissertação em 2003, Arbex declarou que uma das razões que levam o jornalista a se distanciar de notícias latinoamericanas é que ele não se sente organicamente ligado (outra vez um termo extraído de Gramsci) à América Latina. Essa declaração de Arbex soma mais uma polêmica numa questão já abordada por Perseu Abramo $^{50}$ em 1977: a falta de identidade do jornalista com um trabalhador assalariado.

\footnotetext{
${ }^{49}$ LOBO, Flávio. Uma crise de Identidade Cinqüentenária. In: Carta Capital. São Paulo. 22 de Junho de 2005.

${ }^{50}$ ABRAMO, Bia (Org.) Um Trabalhador da Notícia: Textos de Perseu Abramo. São Paulo: Ed.

Fundação Perseu Abramo, 1997.
} 
Por um lado, o jornalista se define como intelectual. Na óptica da Receita Federal é um profissional liberal, mas a verdade é que ele está sujeito a todas as relações de trabalho dentro da ordem capitalista: tem jornada de trabalho (muitas vezes além do horário combinado), recebe remuneração mediante a venda da sua força de trabalho e recebe ordens dentro da hierarquia da empresa em que trabalha. Na essência, não há nada que diferencie o jornalista dos demais trabalhadores. Porém, em razão da história da profissão (os primeiros jornalistas, de fato, eram donos de seus próprios jornais) e da peculiaridade do produto produzido pelo jornalista (informação, notícia, opinião) ele é legitimado pelo público receptor como um representante de um outro poder dentro da sociedade.

Porém, como mostraram Bourdieu, Arbex, Ramonet e Nazareth, esse poder não é real, mas apenas representativo de quem exerce realmente o poder real: as corporações capitalistas. Os meios de comunicação são aparelhos ideológicos que representam esse capitalismo, seja por meio das empresas detentoras dos veículos, seja por meio de aparelhos estatais a serviço do capitalismo. Portanto, é muito difícil a organização dos jornalistas da grande imprensa como uma classe de trabalhadores na medida em que eles se tornam porta-vozes da ideologia capitalista dentro dos veículos em que trabalham. E o que é pior: os jornalistas que alcançam posições de chefia nas redações da grande imprensa - assim como a burguesia, a elite dirigente e parte da intelectualidade - também não se sentem pertencentes à América Latina. Há dificuldade de afirmação do caráter brasileiro - que depende da chancela do exterior - e isto se multiplica no caso latinoamericano. O jornalista da grande imprensa se sente pertencente à América Latina Oficial, o que significa sentir-se europeu ou norte-americano. 
Como no Brasil, o mundo do trabalho é desqualificado ${ }^{51}$, ou seja, como historicamente o trabalhador é depreciado nas relações políticas, a organização dos jornalistas em classe fica ainda mais complicada. A falta de unidade da classe trabalhadora jornalística, associada à crise apontada por Ramonet, deixa ainda mais agudas as complicadas relações de trabalho nas redações. O desenvolvimento de tecnologias como a comunicação de dados por modem, fibra ótica, satélite e telefonia celular revolucionou também os gêneros jornalísticos. O sinônimo de eficiência jornalística para os atuais veículos de comunicação é informação em tempo real. ${ }^{52}$

Informação em tempo real, com apuração detalhada dos fatos, a precisão na redação e ilustrações fartas de infográficos e imagens transformaram o jornalista num supercomunicador, que deve apurar antes dos outros, escrever com perfeição, conseguir todas as ilustrações necessárias à matéria e publicar rapidamente sua reportagem. A conseqüência é o aumento da pressão sobre os jornalistas.

Essa peculiaridade do início do século XXI só aumenta as já conhecidas pressões: grande número de pautas a serem cobertas por um único jornalista; tempo curto para apuração e espaço reduzido para a quantidade de informações necessárias, resultado dos projetos gráficos que privilegiam o visual.

É urgente uma ação tanto de sindicatos e entidades de classe, como das Escolas Superiores e órgão governamentais (e principalmente do próprio jornalista, seja ela da grande imprensa ou não) quanto à pornográfica existência das Pessoas Jurídicas, ou seja o jornalista abre uma empresa e "presta serviços" às empresas recebendo proventos por meio de notas fiscais. Foi a solução encontrada pelas empresas para diminuir os gastos com encargos trabalhistas e aceita pelos profissionais para se estabelecer neste mercado e que dificulta ainda mais a organização sindical da categoria.

O cenário é grave. De um lado o jornalista está indefeso com o processo de despolitização das redações; da desregulamentação da profissão e da depreciação das ${ }^{51}$ PRADO, Caio. in MARINI, Ruy Mauro \& MILLÁN, Márgara (org.) La Teoría Social

Latinoamericana: textos escogidos. Tomo II. México: Univesidad Nacional Autónoma del Mexico, s.d., p 99-121

${ }_{52}$ Sobre a pressão provocada pela chegada da Internet, ver Capítulo III para outros detalhes. 
relações trabalhistas; do enfraquecimento dos sindicatos - conseqüência também da degradação descrita por Beatriz Sarlo; do aumento dos assuntos-ônibus que visam ao aumento do índice de audiência, da relação de poder no cotidiano das redações (hierarquia de diretores, editores e repórteres, apesar de muitos serem jornalistas ao serem colocados em cargos de chefia adotam a postura e a ideologia da empresa) e da relação com anunciantes, o que obriga muitos repórteres, principalmente no rádio, a assinar as matérias com o nome dos patrocinadores. Do outro lado, o jornalista é vítima de seu despreparo intelectual que leva a aceitação da pauta consensual: o que um veículo publica é tido como verdade absoluta e os outros veículos se pautam a partir desta pauta inicial.

Sobre o despreparo intelectual, há ainda um outro aspecto a ser considerado. O desconhecimento da América Latina vem desde a Educação Básica, mas, no caso dos jornalistas, é acentuado no Ensino Superior. Num currículo fragmentado, as disciplinas de subsídio teórico que podem gerar o repertório cultural necessário para incluir a América Latina nas categorias de seleção de notícias têm caga horária restrita e aparecem dispersas dentro da carreira discente. A mudança no currículo do curso de Jornalismo, com a inclusão de disciplinas como História da América Latina, pode contribuir para mudar a formatação dos óculos dos futuros jornalistas.

Por isso, a luta pelo reconhecimento da América Latina no noticiário brasileiro passa também pela mudança nas relações de trabalho nas redações, pela conscientização do jornalista como classe trabalhadora pertencente à América Latina, pela reestruturação do currículo do Ensino Superior de Jornalismo e - por que não? - do currículo do Ensino Básico.

$\mathrm{Na}$ opinião do autor desta dissertação, tão importante quanto apontar as falhas e problemas no jornalismo é também destacar o que se pode fazer, quais são as alternativas para se reverter a situação. Um trabalho que só levanta a problemática mas não propõe soluções transmite a sensação de incompletude. Nas Teses sobre Feuerbach, Marx lembra que são justamente os homens [seres humanos] que têm o dever de mudar a ordem das coisas. "A coincidência do mudar das circunstâncias e da atividade humana só pode ser 
tomada e racionalmente entendida como praxis revolucionante. Mas, a essência humana não é uma abstração inerente a cada indivíduo. Na sua realidade ela é o conjunto das relações sociais. [...] Os filósofos têm apenas interpretado o mundo de maneiras diferentes; a questão, porém, é transformá-lo" ${ }^{53}$.

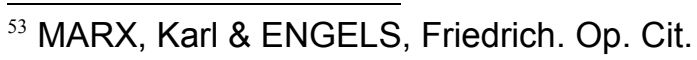




\section{Capítulo I}

Antes do chinó e do fraque

foram os rios, rios arteriais:

foram as cordilheiras em cuja vaga puida

o condor ou a neve pareciam imóveis;

foi a umidade e a mata, o trovão, sem nome ainda, as pampas planetárias.

O homem terra foi, vasilha, pálpebra do barro trêmulo, forma de argila,

Foi cântaro caraíba, pedra chibcha, taça imperial ou sílica araucana.

Terno e sangrento foi, porém no punho de sua arma de cristal umedecido

as iniciais da terra estavam

escritas.

Ninguém pôde

recordá-las depois: o vento

as esqueceu, o idioma da água

foi enterrado, as chaves se perderam ou se inundaram de silêncio ou sangue.

Estou aqui para contar a história.

Da paz do búfalo

até as fustigadas areias

da terra final, nas espumas acumuladas de luz antártica, e pelas lapas despenhadas da sombria paz venezuelana, te busquei, pai meu, jovem guerreiro de treva e cobre, ou tu, planta nupcial, cabeleira indomável, mãe jacaré, pomba metálica.

Terra minha sem nome, sem América, estame equinocial, lança de púrpura, teu aroma me subiu pelas raizes até a taça que bebia, até a mais delgada palavra não nascida de minha boca.

Abertura de $\boldsymbol{O}$ Canto Geral, de Pablo Neruda. 
A América Latina está ausente do noticiário. Não se encontram nas páginas dos jornais as histórias da América Central, as músicas dos pampas argentinos, as lutas na Selva Amazônica, a fome dos descendentes maias, a culinária andina, a literatura guatemalteca, o cinema cubano, a enxada do sertanejo. Tudo que é noticiado entra numa grande geléia geral que os meios de comunicação de massa sequer sabem definir.

Em 2005, durante a cerimônia de entrega do Oscar a composição do uruguaio Jorge Drexler - "Al Outro Lado del Rio" - tema do filme Diários de Motocicleta, dirigido pelo brasileiro Walter Sales concorria ao prêmio de melhor canção. O normal - e nem se poderia esperar o contrário - é o intérprete da música no filme cantá-la na festa de premiação. O estranho foi a escolha dos produtores do show de colocar a interpretação a cargo do guitarrista Carlos Santana e do ator Antonio Banderas. De nada adiantaram os protestos do diretor Walter Sales. A atriz Salma Hayek chamou, com muito orgulho, a dupla midiática para interpretar a primeira música em espanhol a concorrer ao prêmio.

A escolha de Banderas e Santana mostra a visão que o centro tem da América Latina. O ator é o ícone do latino e é o protagonista de quase $100 \%$ das produções de Hollywood de que constam personagens latinos ou ibéricos, que vão do Zorro ao bandoleiro mexicano, passando por jornalistas chilenos e demais latin lovers. Santana é o músico premiado pelo Grammy, portanto chancelado pela indústria cultural norte-americana. Provavelmente, passou pela cabeça do produtor que, da mesma forma como Buenos Aires é considerada a capital do Brasil[!], não haveria problema de trocar um uruguaio por ícones do que os EUA consideram latino-americanos: alguém moreno, de fala espanhola e com nome de pronúncia estranha já serviria. Para a produção do Oscar, provavelmente, o uso de estrelas da indústria cultural seriam uma homenagem à música. Drexler foi premiado. Seria consolação? E cantou a música no palco, por 15 segundos. Enquanto isso, as câmeras focalizaram Banderas - insistência na marca, na grife. No dia seguinte, na imprensa brasileira, apenas comentários, nenhuma indignação, nenhuma reflexão, apenas a tímida, morna, comemoração do Oscar conquistado por Diários de Motocicleta. 
Exemplos como esse se multiplicam diariamente nos noticiários brasileiros. Cuba erradica a tuberculose e, com muito sofrimento, algum veículo solta uma nota. O presidente da Venezuela sofre um gole de Estado orquestrado pela elite branca venezuelana e os jornais se apressam em dizer que o "povo venezuelano derruba Chávez". Da mesma forma, nenhum jornal se preocupou em identificar as razões dos protestos das camadas mais pobres do povo boliviano, de onde vêm os "cocaleros" e porque trabalham nas plantações de coca. Nenhum comentário à secular dilapidação da Bolívia. Para a imprensa brasileira, "cocalero" é sinônimo de bandido; povo é a classe média branca empregada nas multinacionais que pediu a volta do presidente Mesa. A erradicação da tuberculose em Cuba, os processos eleitorais na Nicarágua, as reformas políticas do Uruguai, as negociações em Chiapas, nada tem espaço. As negociações políticas pelos diversos países latino-americanos só ganham manchete quando, por acaso, explode um conflito.

Nos jornais, rádios e tevês aparecem apenas os desastres, as enchentes, os incêndios, as guerras, mesmo assim quando muito evidentes e de tal forma sangrentos que já despertaram a atenção da "comunidade internacional". Aparecem também os gabinetes presidenciais - reuniões de cúpulas, acordos comerciais, visitas de secretários de Estado. É como se a América Latina se resumisse apenas ao litoral e às grandes cidades. Ou, o que é mais grave, os meios de comunicação de massa assumem como América Latina apenas o que já foi chancelado pela indústria cultural hegemônica norte-americana.

Octavio lanni identifica, de fato, duas Américas Latinas.

"Há várias nações na nação latino-americana. Elas se mesclam e diferenciam, convivem e antagonizam, conforme a época, o jogo das forças sociais. Uma é a nação burguesa, oficial, dominante, que profere o discurso do poder, mercado, desenvolvimento progresso, produtividade, racionalidade, modernização. Outra é a popular, camponesa e operária, dispersa na sociedade e na geografia, revelando-se alternativa diferente, sociedade e comunidade, qualitativa. Mas há, em certos casos, a nação quêchua, aimara, guarani, asteca, maia, negra ou outra, de permeio às diversidades sociais, econômicas, políticas, que mantêm e generalizam hierarquias, preconceitos, racismos. Às vezes, todas essas realidades aglutinam-se em distintas regiões, no âmbito do espaço nacional, de tal modo que pode haver uma nação costeira e outra serrana. Nesses casos, as diversidades organizam-se de tal maneira que as regiões digladiam-se como poderosas estruturas aparentemente autônomas; ou articulam-se sob o mando de uma nação mais poderosa. Assim se forma uma espécie de colonialismo interno". ${ }^{54}$

\footnotetext{
${ }^{54}$ IANNI, Octavio. O Labirinto latino-americano. Petrópolis, Rio de Janeiro: Vozes, 1993.
} 
O objeto ausente desta dissertação não é a América Latina Oficial - esta já é devidamente tratada pela Grande Imprensa. A América Latina Popular é desconhecida até mesmo pela América Latina Oficial.

Levar os leitores dessa dissertação e os futuros pesquisadores a conhecer quais Américas Latinas são essas e as várias tentativas de uni-las e saber o porquê do desprezo da América Latina Popular pela Oficial é o objetivo deste capítulo.

\section{As duas Américas Latinas}

A idéia de uma região do globo denominada América Latina traz em seu contexto, além da necessidade de afirmação, uma necessidade de negação. Porque ser latinoamericano, sobretudo é não ser norte-americano, anglo-saxão ou europeu. Há um conjunto de características - geográficas, históricas e sociológicas - que distinguem o sul do Rio Bravo das regiões ditas "centrais" do planeta (Europa e América anglo-saxã).

Já é complicado admitir que o Brasil e seus vizinhos, geograficamente, pertencem ao "hemisfério de baixo" do globo. Nem o mapa-múndi de Mercator é unanimidade entre os geógrafos. Contesta-se a projeção no planisfério dos países do Norte, tornando-os com isso, maiores do que realmente são e achatando os países do sul. Outra metodologia fosse adotada nas convenções cartográficas e astronômicas, o Sul não estaria na parte inferior, tampouco o norte seria a porção superior. 
Nos meios de comunicação alternativos, as convenções já se alteraram: o símbolo do Fórum Social Mundial - encontro anual de organizações não governamentais, partidos de esquerda e movimentos sociais - coloca os continentes lado a lado caracterizando o lema "um outro mundo é possível". A agência de notícias Carta Maior (www.agenciacartamaior.com.br) adota como logomarca um globo terrestre de "ponta cabeça", ou seja, com o que se chama de Sul na posição superior.

Portanto, dizer que a América Latina compreende a América do Sul, a América Central e o México e as ilhas do entorno não satisfaz. A unidade denominada América Latina é maior do que seu aspecto geográfico. "A América Latina existe", afirma Darcy Ribeiro, porém "a unidade geográfica jamais funcionou aqui como fator de unificação porque as distintas implantações coloniais das quais nasceram as sociedades latino-americanas coexistiram sem conviver, ao longo dos séculos". ${ }^{55}$

O historiador argentino Tulio Halperin Donghi se pergunta, ao iniciar um trabalho histórico sobre a região, se "existem tantas Américas Latinas quantos são os Estados nascidos da fragmentação pós-revolucionária?" A divisão política da América Latina em 37 "micro Américas Latinas" pode, aparentemente, facilitar o estudo, mas também não resolve o problema do que é a América Latina, assunto desta dissertação. Não há, dentro de cada um desses Estados, linearidade suficiente para caracterizá-lo.

Donghi cita um livro chamado Many Mexicos e afirma que esses "muitos Méxicos" não são apenas os que existiram desde o período pré-colombiano à Revolução de 1910, mas inclui também "os que subsistem lado a lado, graças a uma história complexa e a uma geografia atormentada. Antes mesmo da história, a geografia já é causa do contraste entre o altiplano de rica vegetação, o deserto e as costas tropicais; o mesmo ocorre em outros países". ${ }^{56}$ Os vários Méxicos são também as várias Argentinas, as várias Cubas (Santiago de Cuba não guarda as mesmas características que Havana por exemplo), os vários Brasis. Popularizou-se aqui a expressão "Belíndia": o Brasil tem regiões com o desenvolvimento semelhante ao da Bélgica e convive com bolsões de pobreza comparáveis aos dia Índia.

\footnotetext{
${ }^{55}$ RIBEIRO, Darcy. América Latina: a Pátria Grande. Rio de Janeiro: Ed. Guanabara, 1986.

${ }^{56}$ DONGHI, T. Halperin. História da América Latina. Rio de Janeiro: Paz e Terra, 1975.
} 
Darcy Ribeiro vê nesta pluralidade, a maior característica de unidade. "O que sobressai no mundo latino-americano é a unidade do produto resultante da expansão ibérica sobre a América. Aqui, a metrópole colonialista teve um projeto explícito e metas muito claras, atuando de forma mais despótica". ${ }^{57}$ Ou seja, o que é comum em todos os países latino-americanos, apesar de a origem do colonizador ser espanhola, portuguesa, holandesa, francesa ou inglesa, de haver maior ou menor presença indígena ou negra na população, é que em todas as nações se edificaram sociedades constituídas para servir de alimento, em primeiro lugar, para a acumulação mercantil, depois para as fornalhas da Revolução Industrial Inglesa e agora para o imperialismo (ou neocolonialismo) norteamericano.

Os mais de quinhentos anos de história oficial da América Latina, desde que La Hispañola foi pisada pelas botas de Colombo e Vespúcio, reproduzem o incessante estupro das entranhas ricas, desde a exploração de recursos naturais e minerais (pau-brasil, ouro, prata, estanho) até o consumo das vidas, dos corações e das mentes dos trabalhadores. Nesse cruel e sangrento processo de exploração, levado a cabo com prodígio desde a etapa do saque das riquezas até as variadas formas de apropriação da produção mercantil, formou-se classes dominantes nativas da pior espécie porque, funcionam "como gerentes daquele pacto colonial e dessa reprodução cultural. Jamais formaram o cume de uma sociedade autônoma. Eram apenas um extrato gerencial que custodiava e legitimava a colonização. Uma vez independentizadas suas sociedades, o caráter exógeno dessas classes dominantes, forjado no período colonial, e seus próprios interesses induziram-nas a continuar regendo suas nações como cônsules de suas metrópoles". ${ }^{58}$

Este histórico processo de subalternização da classe dominante latino-americana também foi descrito assim na essencial - e obrigatória - obra de Eduardo Galeano:

"Para os que concebem a História como uma disputa, o atraso e a miséria da América Latina são o resultado de seu fracasso. Perdemos, outros ganharam. Mas acontece que aqueles que ganharam, ganharam graças ao que nós perdemos: a história do subdesenvolvimento da América Latina integra, como já se disse, a história do desenvolvimento do capitalismo mundial. Nossa derrota esteve sempre implícita na vitória alheia, nossa riqueza gerou sempre

\footnotetext{
${ }^{57}$ RIBEIRO, Darcy. Op. Cit. p 17-21

${ }^{58}$ Idem. Op. Cit. p. 20
} 
a nossa pobreza para alimentar a prosperidade dos outros: os impérios e seus agentes nativos. Na alquimia colonial e neo-colonial, o ouro se transformou em sucata e os alimentos se convertem em veneno. Potosí, Zacatecas e Ouro Preto caíram de ponta do cimo dos esplendores dos metais preciosos no fundo buraco dos filões vazios, e a ruína foi o destino do pampa chileno do salitre e da selva amazônica da borracha; o nordeste açucareiro do Brasil, as matas argentinas de quebrachos ou alguns povoados petrolíferos de Maracaibo têm dolorosas razões para crer na mortalidade das fortunas que a natureza outorga e o imperialismo usurpa. A chuva que irriga os centros do poder imperialista afoga os vastos subúrbios do sistema. Do mesmo modo, e simetricamente, o bem-estar de nossas classes dominantes - dominantes para dentro, dominados para fora - é a maldição de nossas multidões, condenadas a uma vida de bestas de carga". ${ }^{59}$

Essa classe dominante - dominante para dentro, dominada para fora - cria dentro de cada nação latino-americana uma outra nação burguesa, como descreveu Octavio lanni. Por séculos, a escravidão e a aplicação do modelo econômico primário-exportador produziram estruturas sociais rígidas em que se mesclam desigualdades sociais, econômicas, políticas, raciais e culturais. Formaram-se castas que segregam índios, mestiços, negros, mulatos e brancos pobres.

${ }^{59}$ GALEANO, Eduardo. As Veias Abertas da América Latina. Rio de Janeiro: Paz e Terra, 1982. p 14. 
$\mathrm{Na}$ sociedade de classes, mesmo com diferentes atividades econômicas, a segregação se acentua. Os trabalhadores do campo migram há décadas para as grandes cidades engrossando as fileiras de proletários - e até do lupemproletariado. A burguesia industrial cresce associada a capitais estrangeiros favorecida por agenciais estatais, num processo que se arrasta do início do século $\mathrm{XX}$, se acelera com o neoliberalismo praticado desde o início dos anos 90 e segue sem freios até por governos de aparente caráter esquerdista.

Neruda, no seu Canto Geral, de maneira brilhante chama de "Areia Traída" à etapa que sucede a independência das várias nações. Uma vez "expulso" o colonizador quem continua a explorar o povo e a sugar da terra todas suas reservas são os próprios boliviano, brasileiro, chileno, colombiano, porque assim se chamaram, mas não são dignos de receber a denominação de latino-americanos. No colonialismo interno, a nação popular segue submetida, conquistada por colonizadores que dessa vez são os integrantes na nação burguesa, oficial.

Os agentes nativos dos impérios estão presentes nos centros econômicos, nas capitais, nos bairros de classe média, nas minorias que alcançam o ensino superior de qualidade, nas cidades do litoral. Têm acesso aos dólares de turistas, alimentam-se pelo menos três vezes ao dia, compram jornais e revistas, assinam TV a cabo, são associados de locadoras, locomovem-se carro, alugam casas de veraneio, compram passagens de avião, assistem a montagens de teatro e falam pelo menos uma língua estrangeira - do contrário como seriam agentes dos impérios?

Os filhos da América Latina Oficial estudam em escolas particulares, praticam tênis, natação, fazem terapia em consultórios particulares e têm planos médicos particulares. $E$ os pais da América Latina Oficial cobram o Estado para ampliar a rede de estradas, hospitais e escolas. Vivem em condomínios total ou parcialmente fechados. Têm acesso a todos os bens do Estado, trabalham ou são executivos de empresas multinacionais ou associadas ao capital estrangeiro. São os leitores, produtores e financiadores dos meios de Comunicação. 
As nações burguesa e popular não só são diferentes, como são opostas, antagônicas. As contradições herdadas do colonialismo não só se reiteram, como se aprofundam. Há entre essas nações uma luta de classes, em algumas partes explícita e presente nas ruas e nos campos como na Venezuela de Hugo Chávez, em outras explode de tempos em tempos, como na Bolívia, entre "cocaleros" e a classe média empregada em multinacionais. Em outras, infelizmente, a luta está incubada. É sentida todos os dias nas relações, processos e estruturas que organizam a vida e o trabalho, mas ainda não está nas ruas.

Brasil, Argentina, Equador, Nicarágua, Panamá e tantos outros nomes dados às nações latino-americanas de fato correspondem a territórios, fronteiras, população, história, bandeira, hino, moeda, mercado, comunicações, heróis, santos, monumentos, ruínas, língua, literatura e produções culturais. Mas, para lanni, "são elementos dispersos e abstratos da sociedade nacional. Na maioria dos casos correspondem aos elementos que compõem o discurso do poder, dos setores dominantes. O discurso do poder não engendra a nação. Expressa principalmente o que é a nação burguesa". ${ }^{60}$

Como em toda luta de classes, cada parte tem seus organismos, seus intelectuais e seus órgãos de comunicação. Na América Latina, a nação burguesa domina os meios de comunicação. A grande imprensa, formada pelos principais jornais diários, pelas emissoras de rádio e TV, pelos grandes portais de notícias na Internet, pelas agências internacionais de notícia está ligada à nação oficial.

\footnotetext{
${ }^{60}$ IANNI, Octavio. Op. Cit. p. 33-4.
} 
Mais do que ligada, a imprensa é formada pela nação oficial. Os capitalistas proprietários dos meios de comunicação pertencem à classe dominante da nação oficial burguesa. Os jornalistas que trabalham nesses veículos, mesmo com raízes na América Latina Popular, ao se formar nas escolas superiores de jornalismo e conseguir empregos nas empresas privadas de comunicação, abandonam os óculos da América Latina Popular e passam a ver o mundo com os olhos da América Latina burguesa.

O público-alvo destes veículos não está na América Latina Popular. Por isso, a interpretação do contrato estabelecida por Canclini não pode ser aplicada sem ressalvas. As notícias publicadas pelos jornais têm como destino os cidadãos da América Latina Oficial burguesa. São esses cidadãos que podem comprar os produtos anunciados. Evidentemente, os anunciantes e os patrocinadores da grande imprensa são as empresas capitalistas ou órgãos estatais, porque muitas vezes o Estado é Estado, com todas suas características de proteção, apenas para os integrantes da América Latina burguesa - da nação burguesa oficial.

A América Latina Oficial olha a América Latina Popular com um olhar diferente, mesmo que estejam separadas por uma rua. A América Latina Popular é considerada a periferia, o sul, o subalterno, o campo, a serra, o mestiço, a preguiça, a siesta e a fiesta, a rusticidade gaúcha, o caudilhismo, a violência, a barbárie. O bárbaro é sempre o outro. lanni identifica setores da sociedade latino-americana que trabalham sobre esse maniqueísmo. "São muitos que pensam e agem em termos de civilização e barbárie. Essa é uma fórmula bastante influente em meios intelectuais, políticos, militares e outros, latino-americanos, europeus e norte-americanos. Poucos se colocam as relações recíprocas entre os dois pólos do dilema. Não se interessam pelo contraponto escondido na oposição. Como se fosse possível a prosperidade, conforme o ideário liberal, sem a exploração do trabalho na indústria e na agricultura; o Estado de direito sem o monopólio da violência". ${ }^{61}$

Essa divisão entre as Américas Latinas dentro da complexa América Latina é um dos principais fatores para explicar a ausência de notícias ou a generalização e banalização das

\footnotetext{
${ }^{61}$ IANNI, Octávio. Op. Cit. p 15.
} 
informações. O que está ausente do noticiário é a América Latina Popular (proletária, camponesa, indígena, negra, mestiça). A América Latina Oficial, com todos os gabinetes presidenciais, suas produções culturais inseridas na indústria cultural de massa e seus números resultantes das negociações comerciais, já tem sua fatia garantida.

A América Latina popular é a periferia e como tal só entra no noticiário quando reforça essa condição. É esta a lei do jornalismo, discutida em todos as teses e dissertações desde que se começou a estudar Comunicação Social como ciência social aplicada. O jornalismo, a imprensa, nasceu com o capitalismo. Com a industrialização do início do século XX, no Brasil, como na América Latina, os jornais transformam-se em empresas:

"Submetidos às mesmas leis gerais de competição que regem as relações econômicas na sociedade capitalista moderna. Dentro das empresas há uma separação nítida entre o proprietário do jornal, representante da classe burguesa, e o jornalista, profissional geralmente recrutado entre as camadas médias da classe média urbana. $O$ jornal começa a ser um dado econômico, e não apenas político, graças à sua estreita vinculação com as demais atividades econômicas através da publicidade. Em decorrência, o jornal, como empresa jornalística, passa a defender: a) os interesses econômicos específicos do grupo a que está ligado seu proprietário; b) interesses econômicos dos anunciantes que sustentam o jornal; c) interesses gerais da burguesia e do capitalismo; d)interesses políticos ligados a todos esses interesses econômicos, tanto gerais como específicos". ${ }^{62}$

\footnotetext{
${ }^{62}$ ABRAMO, Perseu. Um Trabalhador da Notícia. São Paulo: Fundação Perseu Abramo, 1997. p
} 282-283. 
Essa "aula" do que é o jornalismo e de sua ligação com o capitalismo é tão difundida que não foi citada de nenhum teórico lotado em uma das grandes universidades brasileiras. Vem de um jornalista militante, por isso estudioso, Perseu Abramo - um grande jornalista. É uma lição aprendida nos dia-a-dia das redações e que deveria ser a primeira do curso de Jornalismo. Ela começa a explicar a ausência da América Latina do jornal. Basta considerar que a América Latina popular não está em nenhum dos interesses mencionados.

Perseu Abramo, porém, chama a atenção para a contradição entre a conduta efetiva do jornalista e a conduta que ele deveria ter ou pela qual deveria lutar. "Na grande maioria dos casos" afirma Perseu Abramo "o jornalista das grandes empresas jornalísticas abdica de tomar consciência da classe social a que pertence". Apesar de ser um trabalhador assalariado e, portanto, vender sua força trabalho em troca de um salário, o que o faria defender os interesses dos mesmos integrantes de sua classe, o jornalista lida com representações ideológicas, ou seja palavras, informações, dados, opiniões, atitudes. Muitas vezes essas representações ideológicas, produto do seu trabalho, são as mesmas adotadas pela empresa proprietária do jornal. Assim, o jornalista tem um duplo papel: "ele vende sua força de trabalho para a defesa dos interesses da burguesia e passa a ser indiferente, quando não hostil, aos interesses do proletariado" ${ }^{63}$

A conduta "ideal" do jornalista é colocada por Perseu Abramo como uma "tendência histórica a ser conquistada". O jornalista deveria assumir sua posição de classe lembrando que faz parte da classe assalariada. Como conseqüência, o jornalista deveria entender a Comunicação Social não apenas como a orientação vinda do alto para baixo, mas como o direito que toda a sociedade tem de ser informada e de produzir orientação, de expressar suas reivindicações. Abramo sabia que essa tarefa não era fácil e, por isso, propunha quatro caminhos aos jornalistas:

a) Afastar-se da condição de assalariado nas empresas e formar uma cooperativa para a edição de pequenos jornais.

${ }^{63}$ Idem. Op. Cit. p 284. 
b) Buscar correlação ideológica entre jornal e jornalista: procurar jornais com posições ideológicas semelhantes

c) Fortalecer-se como categoria profissional por meio de atividades sindicais

d) Lutar pela liberdade de imprensa. Aqui, Abramo apresenta um ponto muito importante. Mais do que a censura estrutural feita pela ditadura - o texto é de 1977 - Abramo já enxerga a autocensura entre os jornalistas, por meio da distribuição de releases. Sobre o processo de autocensura, há mais detalhes no Capítulo III desta dissertação.

É para explicar essa contradição, as razões por que o jornalista não assume sua posição de classe e - principalmente - para dar mais subsídios e força a essa luta da conduta ideal de um jornalista consciente da classe a que pertence (ou a qual estão ligadas suas raízes) e consciente de seu pertencimento à América Latina, que esta dissertação segue apresentando explicações, contextualizando cenários e propondo caminhos.

Uma atuação anterior, no entanto, é mais urgente que reforçar os meios de comunicação da América Latina Popular. Ou seja, é necessário que as nações latinoamericanas rompam com as políticas de subserviência que suas elites se acomodaram a fazer. A integração da América Latina é a extinção da fome e da pobreza, é a realização da reforma agrária, do desenvolvimento sustentável que preserve a fauna, a flora e os recursos minerais e humanos (principalmente), do fortalecimento das culturas e preservação dos folclores. Ou, como afirmou Emir Sader, sobre o papel das esquerdas:

"Um objetivo central da esquerda é a recuperação da política como atividade emancipatória,
de construção da polis, da res publica, da esfera pública, dos bens comuns. O socialismo
pode ser definido como a socialização dos bens materiais e espirituais, como a reconstrução
da sociedade centrada na esfera pública. Essa luta inclui o resgate da militância política, da
militância revolucionária, dessa atividade dedicada e desinteressada, de luta pelos ideais da
humanidade, dos trabalhadores, da construção de uma sociedade sem classes e sem Estado,
sem exploração, nem discriminação, nem opressão, nem alienação. Da militância como
atividade ética, não remunerada, de entrega aos valores de luta pela emancipação de todos,
pelos interesses dos mais pobres, dos mais humildes, dos humilhados e ofendidos."64

${ }^{64}$ SADER, Emir. Corrupção, Esquerda e Direita. In. O Mundo Pelo Avesso. Disponível em www.agenciacartamaior.com.br. Acesso em 26 jun 05. 
Estas ações serão o combustível dos meios de comunicação da América Latina Popular. O primeiro ponto é entender o preconceito que a América Latina Oficial - e por conseqüência seus órgãos de comunicação - tem pela América Latina Popular.

\section{O Preconceito}

Na música "Fruto do Suor" (Tony Osanah/Enrique Bergen), composição gravada pelo grupo Raíces de América, que clama para que o próximo não veja seu vizinho como um estranho, há um trecho intrigante: "a baioneta desenhou fronteiras, a estupidez nos separou em bandeiras". É interessante notar como essa fragmentação em nações reforçou ainda mais a divisão e o preconceito entre as Américas Latinas Oficial e Popular.

Para mostrar uma das faces do preconceito, aqui travestido em cegueira cultural, é interessante analisar o resultado de uma pesquisa realizada entre alguns jornalistas no Estado de São Paulo. O critério da escolha dos entrevistados foi ser responsável pela cobertura internacional no veículo ou ser o editor-chefe, no caso de não existir um editor da editoria de Internacional. Em entrevistas concedidas em 2003, os jornalistas Heródoto Barbero, da rádio CBN, Vicente Adorno, da TV Cultura, Igor Fuser, então na Época, Luis Mota, da rádio Eldorado e José Arbex Jr., do Brasil de Fato, foram questionados sobre as características da cobertura internacional e responderam a um questionário fechado. Nele, várias pautas sobre a América Latina, retiradas dos boletins enviados pela Agência LatinoAmericana de Informação (ALAI), foram apresentadas a estes jornalistas que deveriam responder se as publicariam, com maior ou menor destaque, se seriam subsídio para um programa, ou caderno especial, ou se não interessavam ao público. ${ }^{65}$

Nessas entrevistas, o espanto demonstrado por alguns jornalistas diante da evidência de que não se fala da América Latina mostra que, de fato, há dois mundos separados. Principalmente quando o jornalista vê a ausência com naturalidade. "Nada acontece no Uruguai", "Não me interessa o que se passa na Costa Rica", ou "O público não

\footnotetext{
${ }^{65}$ Ver anexos.
} 
se interessa pelo que há no Peru" foram justificativas comuns em quase todos os depoimentos.

$\mathrm{Na}$ entrevista espontânea em que os entrevistados deveriam relacionar as notícias mais importantes do ano (2003), apenas o diretor do Brasil de Fato apontou fatos da América Latina como de destaque. Igor Fuser apontou a eleição Argentina, além dos episódios da Guerra ao Iraque, o acidente com a Columbus, a epidemia da gripe asiática e a política econômica do governo Lula. Vicente Adorno destacou os acontecimentos em torno da Guerra ao Iraque. O âncora da CBN destacou a eleição de Lula, a transição do governo e o problema da segurança pública. No questionário fechado, em 18 notícias publicadas pela agência de notícias latino-americana (ALAI), os jornalistas se dividiram quanto a publicá-las com destaque e não publicá-las em seus veículos.

Analisando esta pequena amostra de jornalistas de grandes veículos brasileiros, nota-se que as notícias que menos despertaram atenção foram as ligadas à cultura, história e de movimentos sociais indígenas. Por exemplo: a notícia sobre a manifestação de indígenas na cidade mexicana de Montes Azules seria publicada sem destaque por três jornalistas: José Arbex, Igor Fuser e Luis Mota. Heródoto Barbero a considerou sem interesse para o público e apenas Vicente Adorno a publicaria com retrancas explicativas. A retirada de minas terrestres colocadas durante a guerra civil na Nicarágua também foi considerada sem interesse para o público pela maioria dos entrevistados apesar de ser uma excelente oportunidade para um "box" relatando o que foi o conflito entre sandinistas e contras, cujos efeitos respingam até hoje no alto escalão do governo norte-americano.

Interessante notar que as notícias ligadas a tragédias e conflitos foram mais aceitas, como os protestos na Bolívia que provocaram mortos e feridos, em que a maioria dos entrevistados considerou uma notícia a ser publicada com destaque. Também chama a atenção o fato de que, quando a notícia se refere a algum latino-americano que se destacou na Europa ou nos EUA, os jornalistas Ihe dão destaque, mesmo estando ela relacionada à área de cultura, notícia que, em outros momentos, seria considerada de menor destaque. $\mathrm{O}$ mesmo acontece com a notícia de que a literatura latino-americana tem seis Prêmios Nobel 
ou com o fato de um escritor chileno ser bem vendido na Europa. Isto acontece com a notícia de que a da Literatura latino-americana tem seis Prêmios Nobel ou com o fato de um escritor chileno ser bem vendido na Europa.

O jornalista Heródoto Barbero apontou várias notícias (como as negociações para a assinatura da ALCA, porém entre países da América Central) como "sem interesse" para o público, mesmo sendo importantes. O jornalista justificava suas respostas dizendo que daria destaque apenas ao que se relacionasse diretamente ao Brasil ou a vizinhos muito próximos, como a Argentina.

Explicar o resultado desta pequena amostra como resultante da manipulação maniqueísta dos donos de jornal não é suficiente. Dentre os jornalistas entrevistados há editores, repórteres e diretores de jornal. Um dos veículos é uma emissora pública (TV Cultura), outro é ligado a entidades da esquerda (Brasil de Fato) e os demais pertencem a grandes grupos de comunicação. Não houve uma divisão clara: nem o jornal Brasil de Fato publica toda e qualquer notícia sobre a América Latina e nem o da grande empresa publica apenas sensacionalismo. Porém, é importante afirmar que o único veículo que realmente dava atenção para as pautas latino-americanas foi o Brasil de Fato, que destina uma página exclusiva para a região.

Novamente, há um conjunto complexo de fatores que interagem para montar este cenário, como se verá nos próximos capítulos. Entretanto, diante de algumas respostas dadas pelo jornalistas, fica clara a existência de um desses fatores: o preconceito. Muitas vezes é o preconceito que faz desaparecer dos noticiários não só a América Latina, mas também a Ásia, a África e qualquer outra região pobre do globo.

Quando um brasileiro da nação oficial olha para seu irmão chileno ou boliviano ele não os vê como "irmão", mas como "o outro". Concepção clássica: bárbaro é o outro! lanni afirma que "a idéia de barbárie está acompanhada do preconceito racial, darwinismo social, quando se criminalizam as reivindicações e os protestos de setores populares do campo e cidade, envolvendo o índio, mestiço, negro, mulato e branco, todos trabalhadores braçais, reforçado pela idéia de que o bárbaro é aquele que pertence a outra casta, a outra classe, 
aos setores subalternos do campo e da cidade. E mais bárbaros ainda, porque reivindicam, questionam, protestam, lutam."66 De acordo com essa idéia, latino-americano é o outro! Bárbaros seriam, enfim, os movimentos populares, os guerrilheiros da América Central, os trabalhadores bolivianos, os operários argentinos, os zapatistas do sul do México, os trabalhadores sem-terra do Brasil.

Para Juan Comas, o preconceito está baseado menos nas diferenças genéticas e mais nos diferentes graus de desenvolvimento, justificado por uma "superioridade racial de um povo eleito", e nasceu efetivamente com a expansão mercantil européia.

"Pode-se afirmar que não havia verdadeiro preconceito racial antes do século $X V$, uma vez que, antes desta data, a divisão da humanidade prendia-se não tanto ao antagonismo de raças mas sobretudo à animosidade entre cristãos e infiéis - uma diferença mais superficial, desde que as divergências entre religiões podem ser vencidas, enquanto que a barreira racial biológica é intransponível. Com o início da colonização africana e a descoberta da América e do caminho para as Índias pelo Pacífico, houve um considerável aumento dos preconceitos de raça e cor. Isto pode ser explicado face aos interesses econômicos, ao fortalecimento do espírito do colonialismo imperialista e a outros fatores" ${ }^{67}$

Comas mostra o erro que cometem determinados grupos ou partidos ao transformar em superioridade racial, erroneamente, o fato de alguns povos que diferem na aparência apresentarem maior ou menor grau de subdesenvolvimento. "A história da humanidade está cheia de 'povos eleitos' que se vangloriam de sua pretensas virtudes e de suas esplêndidas qualidades inatas (...) É esse contraste a verdadeira fonte e origem do racismo" ${ }^{68}$

A história da América Latina foi também a história da estratificação social construída na discriminação racial a crioulos, mestiços, índios e negros. Houve quem justificasse a escravidão com argumentos científicos e históricos, como Juan Ginés de Sepúlveda que admitiu a "inferioridade e perversidade naturais do aborígene americano" assegurando que são "seres irracionais" e que "os índios são tão diferentes dos espanhóis como a maldade é da bondade e os macacos, dos homens". ${ }^{99}$ Ou Hume ao dizer que "estou propenso a crer que os negros são naturalmente inferiores aos brancos". ${ }^{70}$ Do outro lado, o Padre Bartolomeu de las Casas foi um dos poucos que defendeu e lutou pela a idéia de que todos

\footnotetext{
${ }^{66}$ IANNI, Octavio. O Labirinto latino-americano. Petrópolis, Rio de Janeiro: Vozes, 1993. p 14-18.

${ }^{67}$ COMAS, Juan. "Os Mitos Raciais". In: Raça e Ciência. São Paulo: Perspectiva/Unesco. [s.d.]

${ }^{68} \mathrm{Idem}$.

${ }^{69}$ Apud COMAS, Juan. "Os Mitos Raciais". Op. Cit.

${ }^{70}$ Idem
} 
os povos do mundo são constituídos por homens iguais, não havendo "meio-homens" obrigados a obedecer às ordens de outros.

O pior, de acordo com Comas, é usar argumentos psedobiológicos como uma cortina de fumaça para encobrir as intenções opressoras de seus defensores. "A noção de que os mais fortes estão biológica e cientificamente justificados por destruírem os mais fracos foi aplicada tanto em conflitos internos como entre as nações." ${ }^{\prime 1}$ Nos conflitos internacionais, diversas vezes o racismo serviu de desculpa à agressão, pois o agressor não se sentia preso a qualquer consideração - nem mesmo humanitária - que o ligasse a "estrangeiros pertencentes a raças inferiores, classificadas pouco ou nada acima dos animais irracionais". ${ }^{72}$ Não se fala aqui só dos facistas em relação aos judeus, ciganos e homossexuais, nem só dos ibéricos aos índios. Os recentes conflitos no Iraque e Afeganistão e as incursões do Plano Colômbia são exemplos claros deste racismo como desculpa da agressão militar. Mesmo com grupos tão semelhantes nos fenótipos, tal qual acontece no México, é espantoso como o racismo deprecia a luta dos zapatistas de Chiapas como prova o texto escrito pelo subcomandante Marcos, em 17 de março de 1995, sobre o levante no sul do México:

\begin{abstract}
"Nós, os habitantes primeiros destas terras, os indígenas, fomos sendo esquecidos em um canto, e o resto começou a crescer e a ficar forte, tínhamos apenas a nossa história para nos defender e a ela nos aferramos para não morrer. Assim chegou esta parte da história que até parece engraçada, porque apenas um país, o país do dinheiro colocou-se acima de todas as bandeiras. (...) E nós? Cada vez mais esquecidos. A história não era mais suficiente para evitar que morrêssemos, esquecidos e humilhados. Porque morrer não dói, o que dói e o esquecimento. Descobrimos, assim, que não existíamos mais, que os governantes tinham se esquecido de nós na euforia de cifras e taxas de crescimento. Um país que se esquece de si mesmo é um país triste; um país que esquece do seu passado não pode ter futuro. Então tomamos as armas e penetramos nas cidades onde éramos animais. Fomos e dissemos ao poderoso 'Aqui estamos!', e gritamos para todo o país 'Aqui estamos!', e gritamos para todo o mundo 'Aqui estamos!". ${ }^{3}$
\end{abstract}

O racismo é muito pior quando é aplicado não só para separar grupos étnicos (o que já é odiável e desprezível), mas quando afasta as diferentes classes sociais dentro do que seria considerado um mesmo grupo étnico. Comas insiste que não sequer argumentos

\footnotetext{
${ }^{71}$ COMAS, Juan. "Os Mitos Raciais". Op. Cit.

${ }^{72}$ Apud COMAS, Juan. "Os Mitos Raciais". Op. Cit.

${ }^{73}$ SUBCOMANDANTE MARCOS. "Todos somos mexicanos". In: DI FELICE, Mássimo \& MUÑOZ, Cristobal. A revolução invencível: Subcomandante Marcos e Exército Zapatista de Libertação Nacional. Cartas e comunicados. São Paulo: Boitempo, 1998.
} 
científicos que possam justificar o absurdo do preconcieto. "A grande maioria das áreas de civilização avançada são habitadas por grupos surgidos do cruzamento de raças". ${ }^{4}$

É esse olhar preconceituoso que a América Latina Oficial e seus respectivos órgãos de comunicação têm para com a América Latina Popular. Os meios de comunicação de massa brasileiros olham os vizinhos latino-americanos como estranhos, não como iguais. "Parece possível distinguir duas tendências fundamentais na reação ao grupo estranho: uma de admiração e aceitação, outra de desprezo e recusa". ${ }^{75}$

A admiração e aceitação estão reservadas para o mundo das variedades: pela sensualidade, pelo exotismo de comidas e crenças. O programa Globo Repórter sobre a Guatemala a coloca como um lugar místico, colorido, quase que tão distante como as pirâmides do Egito ou tão perdido no tempo quanto os Jardins Suspensos da Babilônia. Na verdade, a admiração - a xenofilia - do brasileiro está mais para os norte-americanos ou europeus, dos quais são assimilados e incorporados costumes, linguagens, crenças e vocábulos.

O desprezo e recusa fazem parte do cotidiano, desde "inocentes" matérias esportivas até as análises políticas. Jogo da Taça Libertadores da América de um time brasileiro contra um time venezuelano, boliviano, equatoriano, peruano ou paraguaio é considerado como "favas contadas". Um grupo de mexicanos mascarados, bolivianos em greve ou desempregados argentinos protestando soam aos jornalistas brasileiros como bárbaros em guerra.

"O estrangeiro", afirma Dante Moreira Leite, "provoca a nossa desconfiança, às vezes nosso medo. Nem sempre entendemos os seus gestos e certamente não compreendemos a sua língua. Ele não se veste como nós, a sua fisionomia pode ser diferente da nossa e não adora os nossos deuses". ${ }^{76} \mathrm{O}$ intrigante é que a xenofobia é aplicada muito mais aos vizinhos do que aos norte-americanos ou europeus.

\footnotetext{
${ }^{74}$ COMAS, Juan. Op. Cit.

${ }^{75}$ LEITE, Dante Moreira. "As raízes do caráter nacional". In: O Caráter Nacional Brasileiro. São Paulo: Editora Ática, [s.d.] p. 15-36.

${ }^{76}$ LEITE, Dante Moreira. "As raízes do caráter nacional". In: O Caráter Nacional Brasileiro. São

Paulo: Editora Ática, [s.d.] p. 15.
} 
A Inglaterra, durante décadas, estimulou os conflitos entre países da América do Sul, estimulando a rivalidade Argentina vs. Brasil, ao mesmo tempo em que adoçava a boca das elites autóctones com as migalhas do desenvolvimento capitalista, trazendo velhas locomotivas, embarcações ou gastando suas libras nos prostíbulos.

De acordo com Moreira Leite o nacionalismo - e suas conseqüências - nasce das elites e depois é inoculado nas massas. "Os grupos dominantes impõem - através da educação e dos vários meios de comunicação - o sentimento patriótico, o que evidentemente seria desnecessário se este fosse espontâneo nas massas populares". ${ }^{77}$ Assim, o jornal, o rádio e a televisão, como instrumentos de um movimento intelectual e político, impuseram o nacionalismo e o patriotismo, acentuando-os em períodos de crise ou guerra. Na esteira, os preconceitos como preguiça do povo que se perde em siestas e fiestas, e às "repúblicas de bananas" governadas por ditadores corruptos - para ficar em apenas dois exemplos - também são cultivados nos setores populares pelos meios de comunicação de massa. Para Darcy Ribeiro, este racismo escamoteia a realidade da dominação colonial, neocolonial e classista:

"Sobre a propalada preguiça latino-americana deixe-me dizer-lhe que um operário da
Volkswagen do México ou de São Paulo trabalha o mesmo ou mais que seu colega alemão,
ganhando um salário cinco vezes menor. O mesmo ocorre com o bóia-fria do Paraná ou o
vaqueiro da Bahia, que trabalham mais do que qualquer peão do Texas, labutando em
condições muitíssimo piores e ganhando dez vezes menos. (...) A preguiça entre nós, com
luxúria e o dengo, nunca foram coisa de negro nem de índio ou de mulato e nem mesmo de
branco pobre. É a fatia do branco rico, a mais gostosa de suas muitas regalias (...) O
mandonismo caudilhesco que também nos atribuem não é coisa nossa; não é debitável ao
povo latino-americano. Ele é que sofreu e sofre na carne a boçalidade dos régulos
escravistas, coloniais ou multinacionais que a civilização européia e sua filial ianque nos
impõem como seus servidores mais fiéis (...) Ditadores tropicais sanguinários, como Somoza,
Trujillo e Batista, são criaturas que Washington criou, amestrou e nos impôs para perpetuar o
domínio ianque sobre as 'repúblicas de bananas' que mantém no Caribe. Olhe um pouco para
a Nicarágua, El Salvador e a Guatemala e se pergunte quem é quer reter a lucrativa tradição
bananeira?". ${ }^{78}$ A América Latina tem sim a seu favor, novamente apenas para dar exemplo no campo da música e da literatura, nomes de muito valor que nada apresentam de depreciativo da música e literatura de outras partes do planeta. No Brasil, Cecília Meirelles,

\footnotetext{
${ }^{77}$ LEITE, Dante Moreira. "As raízes do caráter nacional". In: O Caráter Nacional Brasileiro. São Paulo: Editora Ática, [s.d.] p. 23.

${ }^{78}$ RIBEIRO, Darcy. Op. Cit. p.101-03.
} 
João Cabral de Melo Neto, Carlos Drumond de Andrade, Chico Buarque, Nara Leão, Caetano Veloso, Elis Regina e Tom Jobim. Na Guatemala, Miguel Ángel Astúrias. Na Nicarágua, Carlos M. Godoy. Na Colômbia, Gabriel García Márquez. No Chile, Pablo Neruda, Gabriela Mistral, Victor Jara, Violeta Parra. Na Argentina, Júlio Cortázar, Jorge Luis Borges, Ernesto Sábato, Mercedes Sosa e Atahualpa Yupanqui. Em Cuba, Ibrahim Ferrer, Pablo Milanes, Nicolas Guillén e Silvio Rodrigues. Apenas alguns nomes de uma grande lista.

A complexidade cultural da América Latina também é grande e merece a atenção dos meios de comunicação: sua complexidade musical, por exemplo, parece despercebida pelos jornais de cultura brasileiros. Há grupos com características semelhantes espalhados por diferentes regiões: os de influência negra como o samba, a salsa, o merengue, a cumbia e a rumba; os de influência indígena, como as músicas andinas e as da América Central e as de influência camponesa, resultado da mescla do índio com o trabalhador branco pobre, como as guarânias e as sertanejas; o último grupo é o da música urbana, como o tango, as milongas e os boleros.

A música camponesa na América Latina reúne muitas características comuns, como a temática do amor, do trabalho rural, apologia à natureza e à vida simples. A música paraguaia é triste, talvez reflexo do desastre em que ficou o país após o massacre da Guerra do Paraguai. Ao som da harpa paraguaia as letras descrevem situações de muita dor e solidão.

Também trágicas são as músicas chilenas, principalmente as de Violeta Parra, outro grande nome da poesia chilena ao lado de Nicanor Parra. Ritmadas pela quena, pelo charango e pela sampoña, a música chilena é muito ligada ao regional, à descrição do cotidiano do país. Já o drama do tango tem uma carga grande de machismo e da vida urbana de Buenos Aires, com melodias igualmente tristes.

As músicas de influência negra são alegres. Apesar da trágica história dos negros nas Américas, elas trazem o ritmo forte e contagiante. O único lugar em que a música negra é triste é o sul dos Estados Unidos, onde os lamentos e orações dos trabalhadores negros 
deram origem ao soul, ao blues e, conseqüentemente ao rock. O samba brasileiro segue a característica de música alegre e descontraída de seus ritmos irmãos do Caribe.

As manifestações folclóricas são diversificadas e ricas de lendas, mitos e canções. No campo da literatura são seis Prêmios Nobel entre os escritores latino-americanos. Alguns são autores de obras fundadoras, como o Canto Geral, de Pablo Neruda e Week-end na Guatemala, de Miguel Ángel Astúrias. Outros, com histórias emocionantes, como a professora primária Gabriela Mistral, autora de Desolación, La Lengua de Martí, Tala e Poema de Chile. Cem Anos de Solidão, de Gabriel García Márquez é constantemente eleito como uma das obras mais importantes da literatura mundial, até mesmo pelos norteamericanos, ${ }^{79}$ mas nem mesmo essa chancela o transforma em leitura obrigatória nas escolas e universidades. A chilena Isabel Allende, sobrinha de Salvador Allende, o primeiro presidente socialista a tomar o poder pela via eleitoral, é uma das escritoras mais vendidas no planeta, retomando a linha do realismo fantástico de García Márquez, Ernesto Sábato e Júlio Cortázar.

Para os preconceituosos, lanni deixa um recado: "Aquele que imagina que o bárbaro é o outro esquece que o eu não basta por si, que o eu depende do outro. [...] O contraponto está em que a civilização produz a barbárie, ambas engendram-se reciprocamente, uma inexiste sem a outra". 80

\footnotetext{
${ }^{79}$ Em novembro de 2003, o ex-presidente norte-americano Bill Clinton declarou que Cem Anos de Solidão é um dos livros mais universais que já leu durante evento de lançamento das memórias de García Márquez nos EUA.

${ }^{80}$ IANNI, Octavio. Op. Cit. p. 15.
} 


\section{3 - A herança colonial e neocolonial na criação das duas Américas Latinas}

A influência do processo colonial na história da América Latina é assunto fartamente debatido. Michael Löwy, por exemplo, organizou uma coletânea de estudos marxistas latinoamericanos em que os autores debatem se houve ou não feudalismo na região e como a colônia de exploração foi um processo que ora acelerou ora atrasou a acumulação capitalista $^{81}$.

Albert Memmi e Frantz Fanon, dois autores estudados pelo filósofo francês Jean Paul Sartre, vão além do colonialismo e estudam o neocolonialismo. A influência, claro, é o processo de luta pela independência das colônias européias (principalmente as francesas) na Ásia e na África após a Segunda Guerra Mundial. Fanon e Memmi assumem postura revolucionária, conclamando os "colonizados" a lutar contra a opressão colonial. Mesmo se tratando de casos particulares, a descrição que os autores fazem da relação colonizadorcolonizado servem de parâmetro para mostrar a cisão entre a América Latina Oficial burguesa - herdeira direta dos privilégios do colonizador e a a América Latina Popular "caldo" que se formou do processo de colonização.

Jean Paul Sartre, no prefácio da obra de Fanon, atribui à Europa a sensação do Dr. Frankenstein diante do "monstro" que criou ao se deparar com a resposta das colônias em revolta. "Em suma, isso queria dizer: de nós fizestes monstros, vosso humanismo nos supõe universais e vossas práticas racistas nos particularizam". ${ }^{22}$ Mais à frente, Sartre coloca em xeque o discurso humanista europeu. Na realidade, a prática colonialista européia justificava a opressão e a repressão.

"Nossos soldados de ultramar rechaçam o universalismo metropolitano[..] uma vez que
ninguém pode sem crime espoliar seu semelhante, escravizá-lo ou mata-lo, eles dão por
assente que o colonizado não é o semelhante ao homem. Nossa tropa de choque recebeu a
missão: [...] a ordem é rebaixar os habitantes do território anexado ao nível do macaco
superior para justificar que o colono os trate como bestas de carga. A violência colonial
procura desumanizá-los. Nada deve ser poupado para liquidar as suas tradições, para
substituir a língua deles pela nossa, para destruir a sua cultura sem lhes dar a nossa; é

${ }^{81}$ LÖWY, Michael (org.). O Marxismo na América Latina. São Paulo, Ed. Fundação Perseu Abramo, 1999.

${ }^{82}$ SARTRE, Jean Paul. Prefácio de FANON, Frantz. Os Condenados da Terra. 2. ed. Rio de Janeiro: Civilização Brasileira, 1979. 
preciso embrutecê-los pela fadiga. Desnutridos, enfermos, se ainda resistem, o medo concluirá o trabalho: assestam-se os fuzis sobre o camponês, vêm civis que se instalam na terra e o obrigam a cultivá-la para eles. Se resiste, os soldados atiram, é um homem morto; se cede, degrada-se não é mais um homem. [...] e a Europa, que faz ela? Isso não nos impedia de fazermos discursos racistas, negro sujo, judeu sujo, etc [...] um humanismo racista, uma vez que o europeu só pode fazer-se homem fabricando escravos e monstros." ${ }^{83}$

Albert Memmi chama de pequeno colonizador ao privilegiado das colônias, que não dispõe de vários hectares de terras e nem controla as administrações.

"Muitos são vítimas dos senhores da colonização. São por eles economicamente explorados, politicamente utilizados, a fim de defenderem interesses que não coincidem com os seus próprios [...] Se o pequeno colonizador defende o sistema com tanto empenho, é porque é mais ou menos seu beneficiário. [...] para defender seus interesses muito limitados, defende outros infinitamente mais importantes, dos quais é, aliás a vítima. Mas, enganado e vítima, nisso encontra também suas vantagens. [...] Tem prolbemas com as leis? A polícia e mesmo a justiça ser-Ihe-ão mais clementes. Tem necessidade de serviços da administração? Ela serIhe-á menos embaraçosa." ${ }^{44}$

É assim que operam as elites da América Latina Oficial até hoje. Por mais subservientes que sejam às elites dos países centrais do capitalismo, essa condição lhes dá privilégios para garantir sua manutenção no poder local, mesmo que seja um poder muito menor que o das elites européias e norte-americanas. A grande imprensa, em especial a grande imprensa da América Latina Oficial, a serviço desta elite autóctone, também presta este papel de subserviência.

Aos não privilegiados do sistema colonial e neocolonial restam a opressão e o racismo. Porque a colônia jamais será transformada a ponto de se tornar uma metrópole. É preciso marcar posições na ordem internacional do capitalismo: há os centros consumidores e produtores de manufaturas e os centros fornecedores de mão-de-obra e de produtos primários. A desqualificação dos colonizados, por meio do racismo, é a pedra-base da relação colônia-metrópole. "Um esforço constante do colonialista consiste em explicar, justificar e manter, tanto pela palavra, quanto pela conduta, o lugar e o destino do colonizado". ${ }^{85}$

\footnotetext{
${ }^{83}$ Idem. Op. Cit. p 9 a 17.

${ }^{84} \mathrm{MEMMI}$, Albert. $O$ Retrato do colonizado precedido pelo retrato do colonizador. 3 ed. São Paulo: Paz e Terra, 1989. p 27.

${ }^{85}$ Idem. p. 68-9.
} 
O colonizador cria o mito do colonizado sonso, ladrão e preguiçoso para justificar dois tipos de discurso: o da opressão e o discurso da missão civilizatório. Sartre argumenta que o colonizador enxergava o colonizado como um preguiçoso, pois foi uma maneira de justificar o uso da força contra um ser que "vive do nada" 86 .

Memmi diz que o colonizador usa o discurso da desqualificação para justificar a prática da ocidentalização e civilização, método empregado freqüentemente pelos EUA ao longo da história e mais recentemente na "cruzada contra o terrorismo" por todo o globo.

\begin{abstract}
"Pela sua acusação, o colonizador institui o colonizado como ser preguiçoso. Decide que a preguiça é constitutiva da essência do colonizado. [...] Voltamos sempre ao racismo, que é bem uma substantificação, em proveito do acusador, de um traço real ou imaginário do acusado. [...] Graças a uma dupla reconstrução do colonizado e de si mesmo, procurará justificar-se: portador dos valores da civilização e da história, cumpre uma missão: tem o grande mérito de iluminar as trevas infamantes do colonizado. Que esse papel Ihe traga vantagens e respeito nada mais justo: a colonização é legítima." ${ }^{87}$
\end{abstract}

Desse processo de exploração vem a gênese da cisão entre as Américas Latinas. "A Europa multiplicou as divisões, as oposições, forjou classes e por vezes racismos, tentou por todos os meios provocar e incrementar a estratificação das sociedades colonizadas". Pelo raciocínio de Sartre, as colônias, ao se libertarem das metrópoles, se a revolução nacional triunfasse, seriam socialistas. Caso fosse detidam, eram as burguesias nacionais forjadas pelos colonos que tomariam o poder. Desta forma, mesmo se formando um Estado nacional, o poder continuaria nas mãos dos imperialistas. ${ }^{88}$

Frantz Fanon, em Os Condenados da Terra descreve o mundo dividido dos colonizados, fabricado pelos colonizadores.

"O mundo colonizado é um mundo cindido em dois. A linha divisória, a fronteira é indicada
pelos quartéis e delegacias de polícia. Nas colônias o interlocutor legal e institucional do
colonizado, o porta-voz do colono e do regime de opressão é soldado. Nas sociedades do
tipo capitalista, o ensino religioso ou leigo, a formação de reflexos morais transmissíveis de
pai a filho, [...] criam em torno do explorado uma atmosfera de submissão e inibição que torna
consideravelmente mais leve a tarefa das forças de ordem. Nas regiões coloniais, ao
contrário, o soldado por sua presença imediata mantém contato com o colonizado e o
aconselham, a coronhadas ou com explosões de napalm a não se mexer. Vê-se que o
intermediário do poder utiliza uma linguagem de pura violência. O intermediário leva a
violência à casa e ao cérebro do colonizado. A zona habitada pelos colonizados não é
complementar da zona habitada pelos colonos. Estas duas zonas se opõem [...] obedecem ao
princípio da exclusão recíproca. A cidade do colono é sólida, iluminada, asfaltada, onde os

${ }^{86}$ SARTRE, Jean Paul. Op. Cit. p. 10.

${ }^{87}$ MEMMI, Albert. Op. Cit. p.72 -9.

${ }^{88}$ Idem. Op. Cit. p. 6. 
caixotes de lixo regurgitam de sobras desconhecidas, jamais vistas, nem mesmo sonhadas. Os pés do colono nunca estão à mostra, salvo talvez no mar, mas nunca ninguém está bastante próximo deles. A cidade do colono é uma cidade saciada. A cidade do colono é uma cidade de brancos, de estrangeiro. A cidade do colonizado, ou pelo menos a cidade indígena, a cidade negra, é um lugar mal afamado, povoado de homens mal afamados. Aí se nasce não importa onde, não importa como. Morre-se não importa onde, não importa de que. É um mundo sem intervalos, onde os homens estão uns sobre os outros, as casas umas sobre as outras. A cidade do colonizado é uma cidade faminta, faminta de pão, de carne, de sapatos, de luz. A cidade do colonizado é uma cidade ancorada, uma cidade ajoelhada, uma cidade acuada. [...] Este mundo dividido em compartimentos, cindido em dois é habitado por espécies diferentes. [...] Nas colônias o estrangeiro vindo de qualquer parte se impôs como o auxílio de canhões e de suas máquinas. [...] A espécie dirigente é ates de tudo a que vem de fora, que não se parece com os autóctones." 89

O colono hoje é o cidadão da América Latina Oficial. O colonizado habita o restante

da América Latina. Desta divisão surge a América Latina Popular, quase que totalmente ausente do noticiário da grande imprensa. A grande imprensa apenas nota a América Latina Popular em situações de interesses específicos que reforçam a separação entre elas. Presente apenas na imprensa alternativa, proletária, a América Latina Popular é condenada a sua solidão não só pela imprensa, mas por todo o aparato forjado pela América Latina Oficial.

\footnotetext{
${ }^{89}$ FANON, Frantz. Os Condenados da Terra. $2^{\circ}$ ed. Rio de Janeiro: Civilização Brasileira, 1979. $p$
} 28-30. 


\section{Capítulo II}

Los pueblos americanos

(Violeta Parra)

Mi vida, los pueblos americanos, mi vida, se sienten acongojados, Mi vida, porque los gobernadores, mi vida, los tienen tan separados.

Cuándo será ese cuando, señor fiscal, que la América sea sólo un pilar. Sólo un pilar, ay sí,

y una bandera, que terminen los líos en las fronteras. Por un puñado de tierra no quiero guerra.

Pode-se discutir se o jornalismo é um espelho fiel, de imagens deformadas, fragmentado em diversos pedaços que refletem realidades diferentes ou uma mistura de todos estes cenários. Contudo, é fato que a produção jornalística reflete a sociedade à qual ele se liga organicamente. Esse espelho, no entanto, pode refletir os sentimentos de uma nação, unicamente os interesses das corporações que participam do jogo do poder ou apenas a sociedade em fragmentos. Mesmo um jornal de esportes pode refletir a frustração de um time de grande torcida ao perder um título em vez da alegria do time do interior que venceu o campeonato pela primeira vez. Há jornais que refletem a visão de alguns setores da sociedade. Os jornais de sindicatos refletem apenas os sentimentos das classes que representam. Da mesma forma, um jornal sediado no Rio de Janeiro pode refletir uma opinião diferente da opinião de um jornal de São Paulo sobre, por exemplo, a guerra fiscal entre os Estados.

Não se trata de hipocrisia. Os veículos de comunicação refletem apenas as ações e os discursos das sociedades em que estão inseridos. Os responsáveis pela seleção do que se vai refletir são os jornalistas. Até aí, não há novidades. O que se discute é que nessa seleção do que vai ser refletido nas páginas dos jornais e das revistas, nas manchetes dos radiojornais ou nas imagens dos telejornais da grande imprensa, a 
diversidade e complexidade da América Latina não ganham espaço nem quantitativo, muito menos qualitativo.

Ao explicar, no Capítulo I, a qual América Latina esta dissertação se refere, foi mencionada a questão do preconceito como uma das conseqüências do processo histórico de formação da região, uma história feita de confrontos entre as elites e as camadas populares. Desde os primeiros indígenas que resistiram à invasão espanhola até as passeatas contra a ALCA pelas grandes metrópoles, vários blocos de diferentes interesses e posições ideológicas se formaram na América Latina e três deles podem ser identificados especificamente para esta pesquisa.

Um é o bloco dos explorados, escravizados ou torturados. O bloco que resistiu, resiste e luta. O bloco que se considera latino-americano, formado ora por escravos indígenas ou africanos, ora por camponeses e operários, sempre as camadas mais pobres, excluídas do jogo do capital.

Outro é o bloco formado pelos conquistadores estrangeiros. Primeiro espanhóis, portugueses, franceses, holandeses. Depois ingleses. Finalmente, norte-americanos. Aqueles que fincaram seus dentes nestas terras e dela tudo sugaram. Da madeira ao ouro. Da fertilidade do solo à vida de trabalhadores. E sugaram também a liberdade. A liberdade de agir, de pensar, de seguir com as próprias pernas a história de cada povo.

O terceiro bloco é formado por aqueles que Pablo Neruda chamou de traidores na obra Canto Geral. São aqueles que, nascidos nestas terras, também deveriam se chamar latino-americanos e em determinados momentos da história até se valeram deste termo para alcançar o êxito de seus interesses. No entanto, tendo de escolher entre o primeiro e o segundo bloco, preferiram se aliar ao segundo, o dos opressores, contra o primeiro, dos explorados, isso para viver como apêndices ou agentes dos interesses estrangeiros e garantir privilégios, status, propriedades ou outras migalhas do capital.

É esse terceiro bloco de traidores, chamado aqui de América Latina Oficial, que detém os meios de comunicação de massa e que, ao longo da História, constrói a historiografia oficial. Hegemônico, domina corações e mentes, elevando alguns personagens 
à categoria de heróis, de patriotas, enquanto relega outros ao esquecimento. A história da América Latina que se aprendeu até bem pouco tempo nos livros da Educação Básica e que se reproduz nas páginas de jornais e revistas e nas telas dos noticiários é a história por eles escrita.

O nascimento da América e o próprio nome do subcontinente já são motivos de polêmica. Quantos se perguntam porque esta faixa de terra se chama América e não Colômbia, já que seu descobridor foi Cristóvão Colombo e não Américo Vespúcio? A historiografia oficial é simplista e diz que o nome foi dado em homenagem a Américo, o primeiro a admitir que as terras eram um novo continente, mas essa explicação não revela a complexidade do caso. Dizer que a América era um novo continente era trair a Igreja, que pregava o mundo como uma massa de água com apenas a Europa, a Ásia e África. Admitir um novo continente, significava também "a abolição do velho mundo bíblico", característica marcante dos séculos XV e XVI. Américo Vespúcio poderia aboli-lo, sobre ele poderia cair a culpa por fazê-lo. Já Colombo, patrocinado pelos reis católicos, não poderia fazer o mesmo.

A partir daí, a América Latina tem mais de quinhentos anos de História, recheados de episódios tão fantásticos (ou até mais) quanto os reproduzidos exaustivamente nos filmes norte-americanos. As lutas de resistência dos indígenas - muitos com culturas avançadas como os incas, os maias e os astecas - geraram episódios fantásticos e heróis como Tupac Amaru. Da mesma forma as guerras de independência também são ricas de fatos e nomes importantes que merecem ser estudados como Simón Bolívar, San Martín, O’Higgins, Artigas, Manuel Rodriguez, Toussaint L'Ouverture e José Martí. As primeiras décadas do século XX marcaram a América Latina também com lutas e insurreições operárias que renderam nomes como Julio Mella, Miguél Mármol, Luis Emílio Recabarrén e Augusto César Sandino. Durante os anos 60, 70 e 80 as guerrilhas da América Central comoveram o mundo.

Esses exemplos mostram que a América Latina também tem uma História que merece a exibição em documentários, cadernos especiais, ou, no mínimo, reportagens em aniversários de datas importantes. São raros os jornais que fazem matérias sobre o golpe 
de 11 de setembro de 1973 no Chile, por exemplo. A indústria cultural, nas mãos da América Latina Oficial, burguesa, considera mais rentável reproduzir o material norteamericano e a população média conhece mais sobre Lincoln e as Guerras de Independência e de Secessão norte-americanas do que sobre as guerrilhas de resistência às ditaduras militares.

A história de Salvador Allende e a inédita experiência do socialismo que ganha o poder pelo consenso lembram também que a América Latina tem uma triste história de sanguinários golpes de Estado contra as tentativas de libertação do jogo capitalista. Ditadores, como Pinochet que liderou o golpe de Estado no Chile, Trujillo, Videla, Stroissner e Somoza são alguns dos nomes dos traídores que, entre outros malefícios, contribuíram para associar a imagem do continente à imagem de ditadores militares corruptos. É necessário lembrar sempre que esses homens cometeram crimes em seus países e que histórias como essas não podem se repetir. E lembrar é dever dos meios de comunicação.

Além do preconceito e do fato dos meios de comunicação de massa pertencerem à América Latina Oficial, já estudados nesta dissertação, há outros fatores que excluem a América Latina Popular do noticiário: um deles é o histórico desgaste das lutas populares que enfraqueceram os setores populares resistentes à hegemonia - todas as manifestações de origem popular foram duramente reprimidas para servirem de exemplo do que não se podia fazer na América Latina.

Quando essas manifestações triunfaram, o sucesso não chegou ao conhecimento de toda a população seja em razão do silêncio dos meios de comunicação, seja em função da desconfiguração feita por eles. O MST é exemplo desse processo. A repressão histórica empreendida pelos latifundiários organizados no Congresso ou nos próprios meios de comunicação gerou a falsa idéia de que o movimento - a mais original manifestação de esquerda na América Latina a partir dos anos 80 - é um grupo de desordeiros e bandoleiros. A mesma pecha foi atribuída aos grupos de resistência ao golpe militar no Brasil. Não fosse um lento e insistente resgate histórico, as lutas de Marighella, Lamarca, e tantos outros, cairiam no esquecimento. Não que hoje os combatentes da esquerda armada 
tenham reconhecimento devido - muitos familiares sequer conseguiram enterrar seus mortos, ainda constantes da lista de "desaparecidos". Entretanto, isso não comove a mídia. As feridas da ditadura não cicatrizaram.

Ao MST resta o recurso da mídia alternativa. A organização produz o Jornal Sem Terra e a Revista Sem Terra e auxilia diretamente no semanário Brasil de Fato. São publicações organicamente ligadas à América Latina Popular. Não se pautam pelas notícias dos grandes veículos de comunicação e assumem outros horizontes de pauta, como será visto no Capítulo III. Porém, não estão livres do jogo capitalista: dependem do preço do papel, da gráfica, da distribuição. Os jornalistas que produzem esses veículos o fazem também por militância, mas não resistem por muito tempo, sendo obrigados, muitas vezes, a conseguir outras fontes de renda. Contudo, essas publicações resistem e seguem no dever de mostrar o lado do MST.

Esse quadro, uma verdadeira luta de classes entre a América Latina Popular e Oficial, associado à influência norte-americana na vida cultural (e "comunicacional") do país e à degradação (impulsionada pelo neoliberalismo) das cidades latino-americanas condena a América Latina Popular à solidão. Esses fatores serão trabalhados neste capítulo. 


\section{A sociedade civil enfraquecida na América Latina popular}

Vientos del pueblo

(Victor Jara, 1973)

De nuevo quieren manchar mi tierra con sangre obrera los que hablan de libertad $y$ tienen las manos negras.

Los que quieren dividir

a la madre de sus hijos y quieren reconstruir la cruz que arrastrara Cristo.

Quieren ocultar la infamia que legaron desde siglos, pero el color de asesinos no borrarán de su cara.

Ya fueron miles y miles los que entregaron su sangre $y$ en caudales generosos multiplicaron los panes. Ahora quiero vivir junto a mi hijo y mi hermano la primavera que todos vamos construyendo a diario.

No me asusta la amenaza, patrones de la miseria, la estrella de la esperanza continuará siendo nuestra. Vientos del pueblo me llaman, vientos del pueblo me llevan, me esparcen el corazón y me aventan la garganta. Así cantará el poeta mientras el alma me suene por los caminos del pueblo desde ahora y para siempre.

Para que o jornalista pense como latino-americano e use os óculos de um latinoamericano para a seleção de notícias - é necessário que ele esteja organicamente ligado à América Latina. Ou seja, é preciso que a sociedade civil produza seus próprios jornalistas orgânicos. Para que surjam jornalistas ligados organicamente à América Latina Popular é necessário que o Brasil tenha uma sociedade civil forte, estruturada e comprometida com esta região.

Como foi visto no Capítulo I, porém, não há uma única América Latina. Cindida em duas, a América Latina Oficial - da elite, dos grandes centros econômicos e políticos, 
branca - e a América Latina Popular - da periferia e dos interiores, mestiça, negra e índia têm sociedades civis distintas.

É de fato uma luta de classes. O termo pode ter caído em desuso pela mídia oficial como se fosse possível eliminar um conceito histórico apenas pela vontade de alguns setores -, mas encaixa-se na realidade latino-americana e ainda é válido. Há uma luta, às vezes silenciosa, às vezes ruidosa e sangrenta, entre a América Latina Popular e a América Latina Oficial e cada setor tem seus aparelhos ideológicos, seus intelectuais orgânicos.

Quando, em algum país ou região, a América Latina Popular ganha força e seus aparelhos ideológicos passam a incomodar a América Latina Oficial, esta não se incomoda de usar todos os meios de repressão ao seu alcance. A repressão pode ser na base da sedução ideológica, como no caso da americanização durante a Segunda Guerra ou da implantação do neoliberalismo nos anos 80 e 90, mas também pode ser pela força, como nas ditaduras, nos golpes e nas guerras civis.

Enquanto a sociedade civil da América Latina Oficial é organizada, na América Latina Popular ela é enfraquecida. Na América Latina oficial, há mais de 500 anos a elite encastelou-se no poder. As mudanças ocorridas foram pactos de elite, como no caso brasileiro, em que a independência foi uma passagem de pai para filho, orquestrada pela elite dirigente, sem nenhuma participação popular. As proclamações de independência, as constituições, as reformas aqui e ali, as sucessões presidenciais, tudo é meticulosamente organizado pela elite, associada desde o início ao estrangeiro explorador, que tem controle total da sociedade civil da América Latina Oficial.

Os partidos políticos, sindicatos (pelegos), organismos administrativos, autarquias públicas, os poderes Judiciário, Executivo e Legislativo, o sistema financeiro, as indústrias e os sistemas de comunicação funcionam como uma máquina azeitada que reprime quando é necessário, que faz concessões em momentos-chave e conduzem como numa sinfonia os mais de 500 anos de permanência no poder. "O modo de produção e a estrutura de classes 
de cada lugar têm sido sucessivamente determinados, de fora, por sua incorporação à engrenagem universal do capitalismo". 90

O sistema educacional da América Latina oficial, da educação básica sedimentada no ensino privado ao ensino superior (público ou não) contribui na cisão entre as América Latinas, seja na exclusão de linhas de pesquisa sobre a América Latina Popular, seja na construção de profissionais, tecnologias e linhas de pesquisa que ampliem o poder da América Latina Oficial.

Os sindicatos pelegos e partidos políticos conservadores não dão voz aos movimentos populares e revezam-se no poder, criando e aprovando leis - quando em regimes ditos democráticos - ou servindo de suporte a regimes ditatoriais, apoiando a repressão às organizações sociais.

Ao se estudar o jornalismo praticado no início da indústria capitalista jornalística, a partir da década de 1930, percebe-se que a América Latina Popular nunca esteve presente. Por isso, não se pode atribuir apenas ao neoliberalismo, fenômeno das últimas décadas do século XX, o cenário de solidão. Os órgãos de comunicação da América Latina oficial nunca se preocuparam - e nem vão se preocupar - com os caminhos da região. A entrada da América Latina Popular só acontecerá nestes meios quando houver interesse estratégico.

Na América Latina Popular, por sua vez, a sociedade civil ainda é muito enfraquecida. A América Latina popular não tem partidos políticos estruturados e nem sindicatos fortes que de fato a representem e lutem por sua integração. Há poucos partidos políticos e sindicatos que atuem em cooperação com os outros latino-americanos. É preciso que a região fortaleça suas instituições dentro do ideal de união e cooperação latinoamericana. As instituições que se fortaleceram, ao contrário, estão muito mais ligadas ao eixo EUA-Europa e à América Latina oficial, do que aos vizinhos latinos.

Entre os principais fatos históricos que enfraqueceram a sociedade civil da América Latina Popular estão o processo de colonização, a escravidão, a constituição das grandes

\footnotetext{
${ }^{90}$ GALEANO, Eduardo. As Veias Abertas da América Latina. Op. Cit. p.- 14.
} 
cidades e os sucessivos processos de exploração, primeiro pelas potências européias, depois pelo imperialismo norte-americano.

A América Latina não é só carente de intelectuais orgânicos, mas, principalmente de inserção no mundo. É preciso inserir a América Latina na materialidade das relações econômicas. Da maneira como a região se desenvolveu até agora, ela está muito mais semelhante a uma figura que Francisco de Oliveira chamou de "ornitorrinco". ${ }^{91}$

O ornitorrinco é um animal improvável na evolução, dentro das teses de Charles Darwin,segundo a qual apenas os seres mais bem adaptados às condições do ambiente conseguem se desenvolver. Os mamíferos ganham dos ovíparos, principalmente dos répteis, pelo fato de terem a capacidade de gerar seus descendentes dentro do útero das fêmeas, o que facilita o combate a predadores, e por terem sangue "quente", ou seja, de controlarem o calor do corpo. Estes dois recursos de independência dos fatores climáticos teriam feito a diferença quando houve a alteração do clima na Terra e os mamíferos, já existentes, conseguiram se desenvolver. Porém, o ornitorrinco ao por ovos e ter uma homeotermia imperfeita e sendo mamífero, é algo esdrúxulo, singular, incoerente.

Da mesma forma está a América Latina, incoerente, esdrúxula. Uma região que se desenvolveu em alguns pontos, como os demais integrantes do capitalismo mundial, e que por outro lado guarda atrasos até anteriores aos da Segunda Revolução Industrial. E não é ousar dizer que há atrasos até da Primeira Revolução, com regiões muito mais próximas ao feudalismo ou aos primeiros anos da exploração mercantil. É improvável, que nos primeiros anos do século XXI, ainda exista tamanha incoerência, mas por estas terras ela está presente nas ruas e nos campos das várias cidades latino-americanas.

${ }^{91}$ OLIVEIRA, Francisco. Crítica à Razão Dualista/ O Ornitorrinco. São Paulo: Boitempo, 2003. 
É desse ornitorrinco que nascem as Américas Latinas Oficial e Popular. subdesenvolvimento da América Latina "não se inscrevia numa cadeia de evolução [marxista] que começava no mundo primitivo até alcançar, por meio de estágios sucessivos, o pleno desenvolvimento. Foi uma singularidade histórica, a forma do desenvolvimento capitalista nas ex-colônias transformadas em periferia, cuja função histórica era fornecer elementos para a acumulação de capital no centro". ${ }^{92}$

Assim como o ornitorrinco é exceção na evolução das espécies, o subdesenvolvimento é a forma de exceção permanente do sistema capitalista que tanto se vangloria de sua "mão invisível" e de suas possibilidades de crescimento espetacular. "O subdesenvolvimento é a exceção sobre os oprimidos: o mutirão é a autoconstrução como exceção da cidade, o trabalho informal como exceção da mercadoria, o patrimonialismo como exceção da concorrência entre os capitais, a coerção estatal como exceção da acumulação privada". ${ }^{93}$ Há barateamento da produção e, ao mesmo tempo, produção de mão-de-obra excedente e crescimento do trabalho informal. A agricultura de subsistência persiste enquanto subsídio para que exista o agrobusiness e o desenvolvimento financeiro e industrial.

A burguesia nacional se aliou ao capital estrangeiro e deu as costas às classes subordinadas. Não promoveu a reforma agrária, processo que poderia acabar com o "exército de reserva" das cidades e com o poder patrimonialista. Nesse processo, a dívida dos países latino-americanos cresceu exponencialmente e, com ela, a financeirização das economias. As características de ornitorrinco se acentuam quando se vê que os países latino-americanos ainda não conseguem produzir conhecimento e apenas copiam ciência e técnica. Para Francisco de Oliveira:

"O ornitorrinco é isso: não há possibilidade de permanecer como subdesenvolvido e aproveitar as brechas que a Segunda Revolução Industrial propiciava; não há possibilidade de avançar, no sentido da acumulação digital-molecular: as bases internas da acumulação são insuficientes, estão aquém das necessidades para uma ruptura desse porte. Restam apenas as 'acumulações primitivas', tais como as privatizações propiciaram: mas agora como o domínio do capital financeiro, elas são apenas transferências de patrimônio. O ornitorrinco está condenado a submeter tudo à voragem da financeirização [...] isso o privará de

\footnotetext{
${ }_{92}$ Idem. Op. Cit. p.126.

${ }^{93}$ Idem. Op. Cit. p.131.
} 
redistribuir a renda e criar um novo mercado que assentaria as bases para a acumulação digital-molecular. O ornitorrinco capitalista é uma acumulação truncada e uma sociedade desigualitária sem remissão." ${ }^{94}$

O jornalismo é produto do capitalismo. Nasceu no comércio entre as nações e se desenvolveu conforme este comércio se desenvolvia. Todos os inventos de comunicação do telégrafo ao rádio - foram impulsionados pelo desenvolvimento capitalista e pela aceleração das relações econômicas. Não há imprensa sem capitalismo. Essa já é uma lei, estudada, comprovada e revisitada por todos os teóricos da comunicação desde Frankfurt até Martim Barbero. Nesse raciocínio, que ainda não dá conta de explicar todo o fenômeno da relação América Latina-jornalismo, a ausência da região do jornalismo pode ser explicada pelo fato de que no sistema capitalista ela é periferia, excluída do capitalismo, uma região esdrúxula, um ornitorrinco que não interessa à imprensa capitalista.

Como foi dito no início deste capítulo, porém, há uma cisão na América Latina e uma luta - desigual é verdade - entre as duas partes. Nesse processo, pode-se perguntar os motivos que não permitem a vitória da América Latina Popular, vitória que arrancaria de uma vez a região dessa condição de incoerência, que eliminasse a burguesia nacional traidora e que levasse, de fato, ao desenvolvimento.

A resposta está na história da América Latina, recheada de episódios em que nação oficial sempre reprimiu todas as tentativas de desenvolvimento autônomo. Em conseqüência disso, todos os intelectuais orgânicos gerados nestas tentativas foram silenciados pela repressão ou esquecidos, isso quando, em vez de criar pensamentos originais, se limitaram a reproduzir tal e qual pensamentos de autores distantes da realidade latino-americana.

Esse processo de repressão às tentativas autônomas, que fixa a América Latina cada vez mais como periferia capitalista e que abafa a possibilidade de que ela se insira na "realidade econômica jornalística", será detalhado a seguir.

${ }^{94}$ Idem. Op. Cit. p. 150. 


\subsection{As manifestações populares e a repressão}

A América Latina só conseguiu ter êxito no processo de independência política das metrópoles ibéricas no século XIX, sob a influência do iluminismo e da Revolução Francesa e da Revolução Americana, ocorridas no século XVIII, graças ao enfraquecimento das metrópoles, envolvidas nas guerras napoleônicas. O tardio processo de independência foi acompanhado de um tardio - e lento - processo de abolição do trabalho escravo. Só no início do século $X X$ a região iniciou o processo de industrialização, e, com a chegada dos imigrantes espanhóis e italianos surgiram, os primeiros sindicatos e organizações anarquistas.

Acostumadas a reprimir de forma violenta as manifestações de escravos (indígenas ou negros), as elites latino-americanas não admitiram a possibilidade de greves operárias. A primeira greve operária do Brasil foi violentamente reprimida em 1917. No Chile, a primeira grande sublevação operária foi em Iquique, no norte do país, em 1907 e foi de tal forma reprimida que o episódio ficou conhecido como o Massacre de lquique, ocasião em que três a quatro mil operários foram mortos.

Nas nações latino-americanas, salvo em Cuba e na Nicarágua, foram pactos de elite que proporcionaram transformações na vida política, desde os processos de independência, seguidos de uma série de pactos criados para se fazerem as reformas sem perder os privilégios e sem afetar as classes dominantes, como se deu com a abolição, a proclamação da República e as aberturas nos regimes militares.

O poder sempre ficou com a elite e esta sempre foi comprometida economicamente com o capital estrangeiro. Os meios de comunicação de massa são porta-vozes, aparelhos ideológicos, dessas elites e construíram a história dos vencedores, na qual as elites, associadas às potências estrangeiras - primeiro Inglaterra e França depois os EUA - têm o papel principal. Para o historiador Júlio José Chiavenato, "uma das características básicas 
da historiografia oficial é negar ao povo qualquer participação profunda nas mudanças da sociedade" ${ }^{95}$.

Todas as tentativas de manifestação populares ou do mundo do trabalho - desde a época da escravidão até as greves operárias - foram duramente reprimidas na tentativa de não permitir que o exemplo não fosse seguido. Foi assim com Palmares, com Canudos, com as greves do início do século $\mathrm{XX}$ e com os movimentos guerrilheiros dos anos 60 . Esse processo histórico gerou a desqualificação do mundo do trabalho, o desenvolvimento tardio de classe operária organizada, a forte influência da oligarquia rural, a demora na formação de partidos políticos o que transformou grande parte das instituições da América Latina Popular num conjunto organismos fracos no enfrentamento político.

As empresas proprietárias dos veículos de comunicação herdaram a tradição oligárquica de defesa de seus interesses de classe, conduzindo o debate público para temas que as interessem, como a política econômica do governo e acumulação de capital (por meio da privatização, por exemplo). Conseqüentemente, assuntos que não estejam próximos ao mundo das elites não merecem espaço. As cidades e as economias latinoamericanas foram crescendo a reboque do crescimento norte-americano, o que transformou a América Latina num grande quintal, onde não é importante se alguém é salvadorenho, mexicano, equatoriano ou uruguaio; o que importa é que não é norte-americano ou europeu, os grandes centros do capital que realmente têm valor no debate das elites.

Outra conseqüência do enfraquecimento da sociedade civil é a vulnerabilidade à invasão cultural estrangeira. A América Latina se tornou independente sob a influência cultural e econômica da Europa. A partir da década de 1930, os EUA iniciaram o processo de sedução da região para trazê-la como aliada no combate ao nazismo, o que ficou conhecido como política da boa vizinhança e que resultou na americanização das culturas dos países latino-americanos.

Apenas no século XX a América Latina observou fenômenos sociais e culturais significativos para sua saída da sombra da Europa e dos EUA. Até então, as características

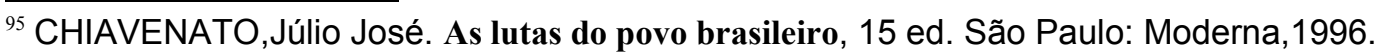


coloniais - economias primário-exportadoras e oligarquias ligadas às metrópoles - se perpetuavam. Interessante notar que no início do século XXI a maioria dos países latinoamericanos continua essencialmente primário-exportadora e ligada aos EUA, a nova metrópole, em uma prova de que a repressão aos já citados fenômenos sociais, e a invasão (cultural e militar) norte-americana foram tão intensas que não houve possibilidade de a América Latina caminhar com as próprias pernas.

Entre os fenômenos essencialmente latino-americanos de destaque do século $\mathrm{XX}$ pode-se citar a Revolução Mexicana de 1910, a Semana de Arte Moderna de 1922, o massacre de Iquique de 1907, a Reforma Universitária de Córdoba de 1918, as manifestações comunistas de El Salvador em 1932, a Revolução Cubana de 1959, a morte de Che Guevara em 1967 (mesmo ano da publicação de Cem Anos de Solidão), a eleição de Allende em 1970, a Revolução Sandinista de 1979, o levante zapatista de 1994 e o aparecimento e fortalecimento do MST entre a metade dos anos 80 e a década de 1990.

Michael Löwy, na organização do trabalho 0 Marxismo na América Latina ${ }^{96}$, uma coletânea de textos dos principais pensadores marxistas latino-americanos esquematizou três grandes períodos da história do marxismo no continente, no século $X X$, que ele chamou de período revolucionário, que compreende dos anos 20 até meados da década de 1930 e é representado principalmente pela obra de José Carlos Mariátegui (Peru), no campo intelectual, e marcado pela insurreição salvadorenha de 1932. A principal característica desse período é a interpretação de que a revolução latino-americana seria, ao mesmo tempo, "socialista, democrática e antiimperialista".

O grande debate sobre a revolução na América Latina era, justamente, o caráter de sua natureza. Como todas as obras sobre o comunismo tinham como base a análise histórico-econômico-social da Europa alguns teóricos buscavam para cada aspecto da realidade européia descrito por Marx e Engels um equivalente latino-americano. Pensando desta forma, a estrutura agrária do continente era classificada como feudal, a burguesia nacional tinha um caráter "revolucionário", chegando a conclusão de que as condições ${ }^{96}$ LÖWY, Michael (org.). O Marxismo na América Latina: uma antologia de 1909 aos dias atuais. São Paulo. Fundação Perseu Abramo, 1999. 
econômicas e sociais na América Latina não estavam "amadurecidas" para a revolução socialista. A saída era efetivar a etapa democrática e antifeudal.

No entanto, ao constatar que o subdesenvolvimento, a desigualdade regional e a profunda miséria do campesinato não eram causadas pelo "feudalismo", e sim pela forma particular do capitalismo aplicado na América Latina (colonial), estudiosos como José Carlos Mariátegui entendem que a burguesia não tem caráter revolucionário e que os países do continente estão condenados à dependência e à submissão ao poder econômico e políticomilitar do imperialismo figurado nos EUA. Assim, o caminho para ultrapassar este subdesenvolvimento e dependência seria romper com o sistema capitalista e adotar o caminho socialista.

Mariátegui, fundou o Partido Socialista em 1928, o jornal operário Labor, no mesmo ano e a Confederação Geral dos Trabalhadores Peruanos no ano seguinte. A principal característica da obra de Mariátegui é a fusão entre idéias avançadas da cultura européia e fortes tradições milenares da comunidade indígena. Ele pensou em assimilar também a experiência social das massas camponesas na aplicação da teoria marxista. Acreditando que a burguesia peruana não seria capaz de promover uma revolução democrática, desenvolveu uma concepção de revolução latino-americana com caráter socialista, incluindo objetivos agrários e antiimperialistas.

Luis Emilio Recabarren (Chile) e Julio Antonio Mella (Cuba) foram os primeiros grandes líderes da fase embrionária do marxismo na América Latina. Ironicamente, esses dois personagens, tão importantes em seus países e na luta social são quase totalmente desconhecidos no Brasil. Em nenhum momento a historiografia, a "intelectualidade" ou a imprensa trazem esses nomes para o debate e discutem a importância de suas idéias.

Recabarren foi o fundador do Partido Operário Socialista do Chile, que se tornaria mais tarde o Partido Comunista, seção chilena da III Internacional. Típico líder de massas, acostumado às tribunas, seus discursos eram inflamados pela luta de classes. Julio Mella seria o primeiro de uma série de figuras típicas da história de resistência na América Latina: intelectuais jovens, em geral estudantes, com espírito revolucionário, anticapitalista e 
antiimperialista que vêem no marxismo a resposta para sua luta. Participante da criação do Partido Comunista Cubano em 1925, Mella propunha a formação de uma frente única antiimperialista, formada de "trabalhadores de todas as tendências, camponeses, estudantes e intelectuais independentes"97.

Em El Salvador, o Partido Comunista, fundado em 1930 por um ex-estudante, Agustín Farabundo Martí, organizou a primeira e única insurreição de massa na história América Latina, sob liderança de um partido comunista, em 1932.

O país da América Central vivia sob a mão de ferro do general Martínez, com um situação social calamitosa. Poucas famílias oligárquicas detinham a posse e controle de praticamente tudo no país, ostentando luxo e riqueza enquanto toda a população estava na miséria. Um documento do Partido Comunista de El Salvador, retrata a situação:

"Por estes motivos, o Comitê Central do Partido Comunista tem armado todos os operários, operárias, camponeses e camponesas para conquistar o poder e estabelecer um governo de operários, camponeses e soldados, que, representados pelos conselhos formados por eles, terão toda a força para esmagar sem piedade os ricos e a burguesia em geral, dando as terras aos camponeses e soldados e protegendo os camponeses pobres que têm seu pedacinho de terra, pois nossa luta dirige-se contra os ricaços que possuem grandes propriedades e fazendas, e não contra os que têm apenas um pedacinho e nem sequer têm onde cair mortos." ${ }^{.98}$

A revolução de 1932 em El Salvador é mais um fato histórico caído no esquecimento da memória até da própria esquerda latino-americana. Mesmo quando o nome de Farabundo Martí voltou às primeiras páginas dos jornais, durante o seqüestro do empresário Abílio Diniz, em 1989, por integrantes do MIR (Movimiento de Izquierda Revolucionário), do Chile e da FMLN (Frente Farabundo Martí de Libertação Nacional), foi feita (salvo raríssimas exceções) qualquer referência a este levante armado de El Salvador.

Quarenta mil combatentes participaram do levante armado, que tinha um programa claramente socialista, liderados por Farabundo Martí, Alfonso Luna, Mario Zapata e Miguel Mármol. A ditadura de El Salvador se informou dos preparativos para a revolução e

\footnotetext{
${ }^{97}$ MELLA, J.A.. Hombres de la revolución, Havana, Imp. Universitária, 1971, p. 37; 77 apud LÖWY, Michael. Op. Cit.

${ }^{98}$ DALTON, Roque. Miguel Mármol: El Salvador (1930-32), em Pensamento Crítico, $n^{\circ} 48$, La Habana, 1971 apud LÖWY, Michael. Op. Cit.
} 
promoveu uma intensa onda de repressão preventiva, prendendo os principais líderes do PC e fuzilando soldados suspeitos de simpatia com os comunistas.

Como resposta a essa repressão, explodiu nas plantações de café uma insurreição camponesa, formada por destacamentos de camponeses indígenas, armados com machetes e alguns rifles, em janeiro de 1932. Por alguns dias ocuparam povoados, fundando "sovietes locais". Sem uma coordenação político-militar centralizada, com os líderes fuzilados e as redes "vermelhas" dentro do Exército já destruídas, foi relativamente fácil para o governo sufocar as insurreições no campo, com a ajuda da "guarda cívica" da oligarquia. Durante algumas semanas, o Exército oficial fuzilou, assassinou e executou cerca de 20 mil homens, mulheres e crianças, num episódio que passou à história como La Matanza. O único sobrevivente deste assassinato em massa foi o líder operário Miguel Mármol.

Concomitante ao domínio de Stalin na URSS, de meados da década de 1930 até 1959, a América Latina conheceu a fase de interpretação soviética de marxismo, ou período stalinista, marcada pela teoria de revolução por etapas. Por essa teoria a América Latina ainda não passara por uma revolução burguesa (nacional-democrática), vivendo um período feudal. O socialismo só seria alcançado após vencida essa etapa feudal, em que proletariado incipiente se aliaria com a suposta burguesia nacional progressista, que faria a revolução democrática e criaria condições para o desenvolvimento do proletariado, por meio do desenvolvimento industrial e urbano. Somente após o amadurecimento destas condições materiais e históricas, o proletariado poderia fazer a sua revolução.

A terceira fase é definida como o novo período revolucionário, que tem como marco a Revolução Cubana de 1959, que traz a consolidação de correntes que defendiam a natureza socialista da revolução e a legitimidade da luta armada. O maior símbolo deste período foi o revolucionário argentino-cubano Ernesto "Che" Guevara.

Ernesto Che Guevara considerava que a revolução deveria ter um desenvolvimento ininterrupto para destruir totalmente o sistema social e todos os fundamentos econômicos atrelados "Não foi por acaso que a primeira revolução socialista da América foi feita sob a 
liderança de revolucionários alheios ao molde ideológico do comunismo stalinista, com sua concepção evolucionista do processo histórico e a sua interpretação economicista do marxismo"99

O que diferencia a Revolução Cubana dos processos revolucionários anteriores, além das características da tomada do poder, é a formação da equipe política dirigente, originária da pequena burguesia inspirada pelas idéias de José Martí e que passou a atuar no campo do proletariado, assumindo-se marxista. Isso foi fruto de um processo iniciado com a destruição do Estado ditatorial de Fulgêncio Batista, seguido pela reforma agrária, da desapropriação e nacionalização de refinarias de petróleo, de empresas de telefonia, eletricidade e usinas de açúcar, a maioria de capital norte-americano. Em 1960 toda a grande burguesia foi desapropriada e no ano seguinte Fidel declarava o caráter socialista da Revolução durante a resistência aos invasores mercenários em Playa Girón.

A Revolução Cubana estimulou o surgimento de novas correntes marxistas inspiradas na idéia de que a luta armada poderia ser um caminho eficaz para destruir uma ditadura pró-EUA e implantar o socialismo. Os escritos de Che Guevara, não só pelo seu papel histórico na revolução, mas pelas doutrinas revolucionárias, também tiveram profunda influência na América Latina ao destacar a importância de uma ética comunista e ao rejeitar o uso das "armas podres deixadas pelo capitalismo (a mercadoria como unidade, a rentabilidade, o interesse econômico individual como motivação etc)". 100

Guevara também definia que a revolução deveria assumir seu caráter socialista, derrotando os inimigos internos (a burguesia e exploradores locais) e os externos (o imperialismo). Num raciocínio contrário à corrente stalinista, ele afirmava que "as burguesias nacionais perderam totalmente a capacidade de resistir ao imperialismo - se algum dia a tiveram - e agora formam a sua retaguarda. Não há nenhuma alternativa: ou revolução socialista ou caricatura da revolução". ${ }^{101}$

\footnotetext{
${ }^{99}$ LÖWY, Michael. Op. Cit.

${ }^{100}$ GUEVARA, Ernesto. "El socialismo y el hombre en Cuba", Obras. v. II, La Habana, Casa de Las Américas, 1970, p 372 apud LÖWY, Michael. Op. Cit.p 45-6.

${ }^{101}$ GUEVARA, Ernesto. "Mensagem à Tricontinental", Obra Revolucionária. México, Era, 1973, 64345. In LÖWY, Michael. Op. Cit. p 286.
} 
Por fim, um terceiro tema comum no pensamento de Guevara é a escolha da luta armada como principal forma de combate aos regimes ditatoriais da América Latina. Especificamente, defendia a luta no campo, impulsionada por um foco guerrilheiro (uma coluna formada por, no máximo, 15 combatentes) que, em contato com a população do campo, promovendo pequenas ações armadas, ganharia cada vez mais adeptos até se tornar um exército guerrilheiro, apoiado por camponeses e operários de todo o país, que conseguisse destituir o poder ditatorial.

Essa teoria, conhecida por foquismo criou uma nova corrente revolucionária na América Latina e em 1960 já se multiplicava o número de organizações armadas no continente, formadas por "rachas" dos partidos políticos comunistas tradicionais e por setores jovens de movimentos e outros partidos. As primeiras guerrilhas rurais foram: FALN (Forças Armadas de Libertação Nacional), dirigidas por Douglas Bravo, na Venezuela onde também surgiu o MIR (Movimento da Esquerda Revolucionária), dirigido por Américo Martín; na Guatemala nasceram as FAR (Forças Armadas Revolucionárias), dirigidas por Turcios Lima e o MR-13 (Movimento Revolucionário 13 de Novembro), liderado por Yon Sosa; no Perú, outra versão do MIR, liderado por Luis de la Puente Uceda, além do ELN (Exército de Libertação Nacional), dirigido por Hector Bejar; na Nicarágua a FSLN (Frente Sandinista de Libertação Nacional); na República Dominicana o Movimento 14 de Junho e o próprio ELN, liderado por Che Guevara, na Bolívia.

Antes da morte de Che, aconteceu em Havana, o congresso da Organização LatinoAmericana de Solidariedade, a primeira tentativa de coordenação da revolução no continente desde Simón Bolívar, quando foi proclamada a "unidade do conteúdo democrático e socialista da revolução latino-americana”.

A morte de Guevara na Bolívia não deixou de influenciar novas guerrilhas pelo continente. Algumas seguiram a opção de travar a luta urbana, outras consideravam a fase urbana uma preparação para iniciar o foco no campo. As ações na cidade serviriam de propaganda armada, teriam forte impacto político e levantariam dinheiro para implantação do foco guerrilheiro rural. Entre essas novas guerrilhas estavam o Movimento de Libertação 
Nacional - Tupamaros, dirigido por Raúl Sendic, no Uruguai, o MIR, no Chile, liderado por Miguel Enríquez e na Argentina o PRT-ERP (Partido Revolucionário dos Trabalhadores Exército Revolucionário do Povo), liderado por Roberto Santucho.

No Brasil, o PCB rachou em diversas organizações; que, por sua vez, também sofreram rachas, principalmente quando se questionava a natureza da revolução: as correntes se dividiam entre os que consideravam a conjuntura nacional imprópria para ações armadas e tentavam aproximação com as massas e os que entravam cada vez mais no militarismo. As principais organizações guerrilheiras foram: ALN (Ação Libertadora Nacional), liderada por Carlos Marighella e Joaquim Câmara Ferreira; AP (Ação Popular); COLINA (Comando de Libertação Nacional); VPR (Vanguarda Popular Revolucionária), que sofreu vários rachas, teve como líderes, em uma de suas fases Onofre Pinto e Jamil Rodrigues e o capitão Carlos Lamarca, que depois foi para o MR-8 (Movimento Revolucionário 8 de Outubro), o qual teve como líderes Franklin Martins, Cláudio Torres e Daniel Aarão. O MR-8 era a dissidência estudantil da Guanabara, um racha do PCB do Rio de Janeiro, e quando seqüestrou o embaixador americano precisava assinar um manifesto. Como a repressão tinha divulgado a destruição de uma organização com este nome, o grupo o adotou como uma maneira de mostrar que a luta continuava. Havia ainda o MRT (Movimento Revolucionário Tiradentes), que fez várias ações em conjunto (ou em frente, como diziam) com a ALN; o PCBR (Partido Comunista Brasileiro Revolucionário), dirigido por Mário Alves; as FALN (Forças Armadas de Libertação Nacional), que tentaram organizar um foco guerrilheiro em Ribeirão Preto, interior do Estado de São Paulo; a FBT (Fração Bolchevique Trotskista), um racha da POLOP (Política Operária) e que mais tarde se agruparia novamente no PT na tendência conhecida como Convergência Socialista e que racharia com o partido dando origem ao PSTU (Partido Socialista dos Trabalhadores Unificado) e a VAR-PALMARES (Vanguarda Armada Revolucionária - Palmares), um racha da VPR. Todas estas organizações foram brutalmente dizimadas pela repressão em seus países, que utilizaram métodos bárbaros de tortura. 
Além do guevarismo, também o maoísmo se desenvolveu neste período. Fundado em 1962, o primeiro partido maoísta da América Latina foi o PCdoB (Partido Comunista do Brasil), dissidência do PCB, tendo como dirigentes João Amazonas, Diógenes Arruda e Pedro Pomar. A orientação do PCdoB seguia o exemplo chinês e pregava a guerra popular, feita por meio do cerco da cidade pelo campo. No Brasil, o PCdoB promoveu uma ação guerrilheira, conhecida como a Guerrilha do Araguaia, de 1971 a 1973, que resistiu a duas ofensivas do Exército brasileiro e foi derrotada apenas na terceira ofensiva, quando foi usado o maior aparato militar do país desde a Segunda Guerra Mundial.

Organizações como o PCdoB surgiram em outros países, como Bolívia, Peru e Colômbia; foi o caso do PCML (Partido Comunista Marxista-Leninista). Na Colômbia, o PCML criou uma importante guerrilha rural, o EPL (Exército Popular de Libertação). Depois da recusa do PCML boliviano de apoiar a guerrilha de Che e dos rumos da política externa chinesa durante a década de 1970, houve uma crise na corrente maoísta da América Latina.

Caso raro entre os PCs foi o chileno, um dos poucos que não sofreram dissidências. Foi o Partido Comunista Chileno que promoveu a mais importante tentativa da chamada "via pacífica" para o socialismo na América Latina, com o governo da Unidade Popular, que tinha o médico Salvador Allende na Presidência da República, eleito por voto popular em 1970. Foi o único caso em que um partido socialista, com plataforma marxista, foi colocado no poder por via eleitoral.

No entanto, de maneira semelhante ao PC brasileiro que analisou erroneamente o quadro de forças no Brasil na época do golpe militar de 1964, o PC chileno buscou de todas as maneiras formar uma coalizão entre a Unidade Popular (partidos comunista e socialista) e as forças burguesas consideradas progressistas, a Democracia Cristã e as Forças Armadas. De acordo com o secretário do PC chileno na época, nas forças armadas reinava "uma consciência profissional e respeito pelo governo constitucionalmente estabelecido". Em setembro de 1973, um golpe militar derrubou o governo de Allende e deu início a uma das mais sangrentas ditaduras da América Latina 
Mesmo com a destruição da maioria das organizações guerrilheiras pelos aparelhos repressores na América, o período revolucionário do marxismo latino-americano ainda sobrevivia. Os anos 80 foram testemunhas da vitória da Revolução Sandinista na Nicarágua e o conseqüente desenvolvimento de novas frentes revolucionárias na América Central.

A FSLN (Frente Sandinista de Libertação Nacional) foi fundada em 1961, sob a influência da Revolução Cubana, mas sobretudo atendendo a uma tradição revolucionária na Nicarágua, tendo como bandeira maior a figura de Augusto César Sandino, lendário líder nicaragüense que expulsou os marines norte-americanos no início dos anos 30 .

A formação da Nicarágua sempre esteve relacionada a lutas de libertação contra colonizadores e invasores, primeiro europeus e depois norte-americanos, que sempre saquearam, exploraram e dominaram o país, interessados em sua posição geográfica na América Central, nas suas características geográficas - seria um excelente local para a construção do canal de ligação entre os oceanos Atlântico e Pacífico - e na sua economia primário exportadora de café e gado. Desde o início do século a Nicarágua passou a ser controlada por norte-americanos, no plano político, militar e econômico, sendo administrada por banqueiros ianques. As invasões de marines no território nicaragüense eram cada vez mais freqüentes. Foi neste contexto que surgiu a figura de Sandino.

Entretanto, a retirada das tropas norte-americanas não significou a liberdade para a Nicarágua. Como herança das décadas de ocupação e exploração ianque foi criada a Guarda Nacional, um exército de confiança dos EUA, que funcionava como um micro aparato de poder ligado diretamente à potência norte-americana. À frente desta guarda foi colocado Anastasio Tacho Somoza, que daria início a uma dinastia ditatorial na Nicarágua, que duraria até a vitória da FSLN em 1979.

Os grupos opositores à dinastia somozista sempre reivindicaram a figura de Sandino, assassinado covardemente pela guarda de Somoza em 1934, e a FSLN se dedicou a preparar ações armadas contra o Estado somozista. Durante a primeira metade da década de 70 a FSLN foi conseguindo apoio popular e passou a atuar também na capital Manágua. 
No final de 74 os sandinistas realizaram sua primeira ação de grande repercussão, num ataque a casa de um integrante do alto escalão do regime. Os irmãos Ortega - Daniel e Humberto -, integrantes de uma corrente que propunha o aumento de ofensivas nas cidades seguiram com ações contra Somoza. Em 1977, a FSLN ocupou o Palácio Nacional de Manágua, capturou alguns integrantes do regime e libertou oitenta presos políticos.

A ofensiva final teve início em março de 1979 e durou até 19 de julho do mesmo ano, quando as forças do FSLN entraram vitoriosamente em Manágua. Dois dias antes, Somoza fugira levando nos bolsos tudo o que pôde carregar de bens do Estado nicaragüense. O programa de triunfo da FSLN incluía a expropriação de todos os bens do clã Somoza, a liqüidação da Guarda Nacional, a construção de uma economia mista, de um sistema político pluripartidário e de uma política externa não alinhada.

Outra particularidade da revolução nicaragüense foi o pluralismo político estabelecido pelo governo. Após décadas de ditadura, os sandinistas entenderam que as primeiras medidas deveriam ser o estabelecimento de direitos democráticos, liberdade sindical, de imprensa e direito de associação. As primeiras eleições da história da Nicarágua aconteceram em 1984 com uma maioria de 67\% dos votos para a FSLN na Assembléia Constituinte.

Apesar desta abertura democrática, não demorou para o governo dos EUA, então representado pelo presidente Ronald Reagan, endurecer as relações com a Nicarágua, promover um bloqueio econômico e financiar uma terrível guerra civil contra-revolucionária (já em 1983, 40\% do orçamento nicaragüense teve que ser destinado à defesa e à guerra civil).

As dificuldades financeiras, a guerra contra-revolucionária e os próprios erros do sandinismo (pouca democracia interna na FSLN, serviço militar compulsório e muitas concessões ao setor privado), levaram ao enfraquecimento do regime e à conseqüente derrota eleitoral dos sandinistas nas eleições de 1990, quando Violeta Chamorro, viúva de Pedro Joaquim Chamorro, líder da oposição a Somoza assassinado em 1977, foi eleita presidente, com apoio de grupos da extrema direita e da burguesia. 
A revolução sandinista causou grande impacto em todo continente, principalmente na América Central, onde El Salvador e Guatemala se encorajaram a desenvolver movimentos revolucionários.

Em El Salvador, várias organizações populares e frentes guerrilheiras de diversas origens (guevaristas, maoístas, cristãos de esquerda, comunistas dissidentes), combinando esforços de organização popular e transcendendo a atividade puramente militar, conseguiram, em 1979, a derrubada da ditadura militar do general Romero. Unidas em 1980 na FMLN (Frente Farabundo Martí de Libertação Nacional), chegaram a controlar um terço do território do país, conseguindo amplo apoio popular no campo e nas cidades. A FMLN adotou a herança do comunismo salvadorenho dos anos 30 e da insurreição de 1932.

$\mathrm{Na}$ Guatemala, inspirados nos sandinistas, as diversas frentes revolucionárias se uniram na URNG (União Revolucionária Nacional Guatemalteca) e se implantaram nas comunidades maias.

Tanto na Nicarágua, como em El Salvador e na Guatemala, a ação revolucionária só foi possível pela fusão do marxismo com as fortes tradições populares de luta social e antiimperialista que ficaram na "memória coletiva" da população explorada. Na Nicarágua, a luta de Sandino contra a intervenção norte-americana; em El Salvador, a insurreição de 1932 e na Guatemala a secular luta dos indígenas contra a colonização.

Outro fator importante e novo nestas ações revolucionárias foi a militância cristã: téologos, jesuítas, estudantes e intelectuais foram atraídos por análises marxistas, criando uma simbiose cristã-marxista, que resultaria na Teologia da Libertação. Multiplicaram-se os envolvimentos de cristãos em associações de bairro, sindicatos, movimentos estudantis, ligas camponesas, centros de educação popular, partidos políticos de esquerda, pastorais sociais e organizações revolucionárias, como a AP (Ação Popular), do Brasil, por exemplo. A morte de Che na Bolívia, as derrotas militares de El Salvaldor e Guatemala, a derrota eleitoral da Frente Sandinista de Libertação Nacional, na Nicarágua e os fatos históricos posteriores à queda do Muro de Berlim e ao desmoronamento da URSS e do Leste Europeu levaram "vários intelectuais ou dirigentes de esquerda 'realistas' a proclamarem o fim do 
período aberto pela Revolução Cubana e o início de uma época de 'consenso democrático', no qual as reformas necessárias se dariam no quadro da economia capitalista de mercado. A revolução seria um capítulo encerrado na história da América Latina, e em seu lugar só poderia ter conseqüência uma política moderada de reformas, implementada por governos de centro-esquerda"102.

No entanto, como já foi citado, a História não pára - novas fissuras se abriram nos muros do pensamento único e, como ela se repete uma vez como farsa outra como tragédia, a América Latina viu, em plena época do aparente discurso triunfante do neoliberalismo, a explosão de movimentos sociais de resistência pelos campos, caso do MST no Brasil e do EZLN, no México.

Justamente no México, país que mais cantava o suposto sucesso do neoliberalismo, teve lugar, no dia $1^{\circ}$ de janeiro de 1994, o espetacular levante dos índios de Chiapas, liderados pelos encapuzados comandantes do EZLN (Exército Zapatista de Libertação Nacional). Mesmo não tendo por objetivo tomar o poder e implantar um governo indígena ou socialista, mas sim incentivar a auto-organização da sociedade civil mexicana, pretendendo transformar profundamente o sistema social e político do país (que vive com um processo eleitoral corrompido e exclui imensas parcelas da população, principalmente do sul e do sudeste), o EZLN é hoje uma referência mundial para os que se sentem vítimas do neoliberalismo. "O novo zapatismo mexicano é um movimento portador de magia, de mitos, de utopias, de poesia, de romantismo, de entusiasmo, de 'mística'; mas ao mesmo tempo ele também é pleno de insolência, de humor, de ironia e de auto-ironia." ${ }^{103}$ O EZLN combina tradições subversivas que formam um cultura revolucionária que ganha força literária nos artigos do mítico Subcomandante Marcos. Dos seus textos e cartas vem a expressão de um sentimento que cresce na América Latina, o do esquecimento dos pobres, dos negros, dos índios e das outras vítimas do neoliberalismo.

\footnotetext{
${ }_{102}$ LÖWY, Michael. Op. Cit. p. 61.

${ }^{103}$ LÖWY, Michael (org.). O Marxismo na América Latina. São Paulo, Ed. Fundação Perseu Abramo, 1999. p 61
} 
O EZLN guarda a herança do marxismo guevarista, que inspirou o núcleo original do movimento, provavelmente na Guatemala, principalmente em seu espírito: importância das armas (que às vezes podem ser simplesmente um pedaço de pau), a ligação orgânica entre os combatentes e os camponeses, o fuzil como símbolo da desconfiança ante os exploradores e a disposição de arriscar a vida pela emancipação dos pobres. Nas palavras de Löwy, "perto da ética revolucionária tal como Che a encarnava". ${ }^{104}$

A inspiração maior é de Emiliano Zapata, que no começo do século, a frente do Exército do Sul, representou a insurreição dos camponeses e índios, a luta contra os poderosos, o programa agrário de redistribuição das terras e a organização comunitária da vida camponesa. Além do programa de luta do EZLN, o internacionalismo e a solidariedade com outros povos e lutas pelo mundo também são influências de Zapata. A palavra de ordem no EZLN continua a ser "terra e liberdade".

Löwy também credita à teologia da libertação uma fonte de inspiração para o zapatismo, como uma forma de conscientização das comunidades indígenas, a autoorganização e a luta pelos direitos. Outra herança recebida pelo EZLN é a tradição da cultura maia dos indígenas de Chiapas, com a relação "mágica" com a natureza, a solidariedade comunitária e a resistência à modernização neoliberal. Como Mariátegui, o EZLN faz constante referência a essa tradição comunitária pré-capitalista, pré-moderna, précolombiana do passado. É correto afirmar que é o atual herdeiro de cinco séculos de resistência indígena à conquista e à civilização. ${ }^{105}$

Além do EZLN, do campo surgem na América Latina outras manifestações revolucionárias de inspiração marxista. De todos os movimentos sociais no campo, o mais importante e bem-organizado é o MST (Movimento dos Trabalhadores Rurais Sem Terra), no Brasil. Apesar de existirem movimentos similares no Paraguai, no Equador, no Peru, no México e na Guatemala, o MST é o que mais se destaca na América Latina pela revolução que está promovendo no Brasil. O editorial da Revista Caros Amigos (n. 6, São Paulo, Casa Amarela), afirma que

\footnotetext{
104 Idem. p 62.
}

${ }^{105}$ Idem. 
"Ao promover uma reforma agrária autêntica, porque elaborada não em gabinetes de poder mas em barracas de plástico e sustentada pela letra da Constituição, o MST concretiza uma revolução sem precedentes na história do Brasil, ainda mais quando embasada na força da argumentação e não das armas, na vontade das maiorias e não de um partido político ou um punhado de generais. E uma revolução que não se limita a impor a reforma agrária somente no tocante à propriedade da terra, mas ao uso da terra na sua função social, econômica e ecológica. Um fenômeno que está repercutindo no exterior e que, de tão forte, vem superando obstáculos até aqui considerados intransponíveis, como o poder dos fazendeiros, dos meios de comunicação e do próprio governo".

A origem do MST está nas comunidades de base e na Pastoral da Terra, mas nos anos 80 ganhou autonomia da igreja, incorporou elementos marxistas na análise da estrutura rural brasileira e no seu programa agrário de inspiração socialista. Sua própria bandeira mostra seu programa: o vermelho, a cor da revolução, é também uma homenagem ao sangue derramado no campo; o preto, o luto pelos companheiros caídos; o verde a esperança pela Reforma Agrária; o branco, a luta pela paz e o homem e a mulher abraçados no centro da bandeira, de facão em punho, representa a luta pelo socialismo. 
Essa explicação da bandeira e a linha política da organização são repetidas por qualquer militante do movimento em toda parte do país. O MST aglutina em suas fileiras analfabetos, pequenos camponeses falidos, bóia-frias, desempregados da cidade e todos os outros miseráveis excluídos da sociedade. Pela sua combatividade, sua "mística", seus métodos de luta - ocupação de terras improdutivas ou devolutas - e sua oposição às políticas neoliberais, o MST conquistou a simpatia de parte significativa dos camponeses, da população urbana e da opinião pública apesar das constantes ofensivas dos meios de comunicação.

Hoje, o MST é a única força efetivamente de esquerda a militar de maneira revolucionária no cenário brasileiro e até mundial. Consciente de sua força, de sua "latinidade", o MST ao realizar ocupações e promover a Reforma Agrária, consegue realizar a coletivização dos meios de produção, coisa raramente alcançada por outros movimentos sociais. No entanto, suas ações não ecoam nos meios de comunicação de massa.

A derrota eleitoral da FSLN e os acontecimentos no Leste Europeu, levaram os movimentos guerrilheiros salvadorenhos e guatemaltecos a aceitar acordos de paz em troca do desarmamento e da oferta de garantias democráticas para atividades públicas legais para organizações de esquerda.

Mais que a queda do Muro de Berlim em 1989 e os episódios no Leste Europeu que provocaram profunda crise nos partidos comunistas identificados com os soviéticos foram a derrota sandinista e as condições econômicas de Cuba que mais provocaram conseqüências para as forças de esquerda. Primeiro, o desarme das guerrilhas da América Central, depois, a ofensiva neoliberal com um discurso triunfante em diversos países como México, Argentina e Brasil, "levaram vários intelectuais ou dirigentes de esquerda a proclamarem o fim do período aberto pela Revolução Cubana e o início de uma época de consenso democrático, no qual as reformas necessárias se dariam no quadro da economia (capitalista) de mercado". ${ }^{106}$

$\overline{{ }^{106} \text { LÖWY, Michael. Op. Cit. p } 61 .}$ 
Por esse raciocínio, não existiria mais espaço para a revolução, que seria um "capítulo encerrado na história da América Latina". No lugar da insurreição popular, ou da revolução armada o único caminho seria a política moderada de reformas implementadas por governos de centro-esquerda, em processos eleitorais e em aliança com outras forças "progressistas". Seria o "fim da história", como chegaram a anunciar diversos intelectuais.

Não bastasse o ainda jovem pensamento sociopolítico, colabora para aumentar a a solidão da América Latina, a existência de intelectuais que publicam obras que ignoram "sistematicamente as lutas populares e jogam todas as fichas no institucionalismo, contribuindo para uma sucessão de derrotas e desânimo"107, como é o caso de Jorge Castañeda.

É importante lembrar que um dos principais fatores que distanciam a América Latina do jornalismo é o fato de jornalistas usarem características de percepção do que é importante ser noticiado ("óculos") que não incluem a América Latina. Como já foi dito, apenas quando os "óculos" dos jornalistas enxergarem também o continente latinoamericano, as notícias correspondentes terão espaço. Infelizmente, esses óculos para a América Latina só serão formados quando o pensamento sócio-político da América Latina se afirmar se desenvolver e formar gerações de intelectuais orgânicos latino-americanos.

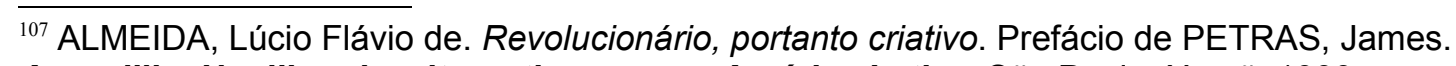
Armadilha Neoliberal e alternativas para a América Latina. São Paulo: Xamã, 1999. 


\section{A americanização do Brasil}

Os EUA já tinham declarado suas intenções pan-americanas com a doutrina Monroe ainda no século XIX. Para fazer cumprir o lema "a América para os americanos" os EUA se valeram ou da ocupação militar - como na Guatemala e na Nicarágua - ou da intervenção política direta - como em Cuba e em tantos outros países - ou até mesmo anexando territórios - caso de Porto Rico. Quando não era o caso de uma intervenção armada direta, usaram o processo de sedução via encantamento pelo "progresso" da economia e cultura norte-americana, como ocorreu no Brasil durante a Segunda Guerra Mundial.

\section{1 - A americanização pela força militar}

Na Guatemala, após a queda da ditadura de Ubico, o país passou por mudanças democráticas até que Jacobo Arbenz, coronel de tendências esquerdistas assumiu a presidência e deu prosseguimento a essas reformas. Entre elas a mais importante foi a legislação da reforma agrária de 1952, que pôs fim ao sistema oligárquico dos latifúndios e nacionalizou as propriedades da poderosa United Fruit Company, a multinacional norteamericana, dona de imensas terras na América. ${ }^{108}$

A United Fruit tinha contatos estreitos com o governo de Eisenhower, presidente dos EUA. Os irmãos Dulles, um secretário de Estado, outro diretor da CIA tinham laços "íntimos" com a empresa. Até mesmo parentes próximos de Eisenhower tinham ligações com a United Fruit. No final de 1953 havia um nítido conflito entre Washington e Guatemala, apesar do governo norte-americano não admitir oficialmente que arquitetava a derrubada dos "comunistas" da Guatemala.

Em janeiro de 1954, o programa clandestino dos EUA, chamado de "Operação Sucesso", contava com apoio dos vizinhos centro-americanos como Trujillo, Somoza e Pérez Jiménez. A marionente guatemalteca, Castillo Armas, ex-coronel do exército e vendedor de móveis, foi chamado para liderar as forças paramilitares mercenárias que estavam sendo treinadas e armadas na Nicarágua de Somoza. Os chefes das missões ${ }^{108}$ SADER, Emir. Século XX: uma biografia não autorizada. O século do Imperialismo. São Paulo: Editora Fundação Perseu Abramo, 2000. P 27-39 e 95-107. 
diplomáticas norte-americanas na Costa Rica, na Nicarágua e em Honduras foram substituídos por homens de confiança da CIA. Para coordenar a "Operação Sucesso", dois meses antes foi nomeado o novo embaixador dos EUA na Guatemala: John Puerifoy. Estava evidente que nuvens negras se formavam no horizonte da Guatemala. ${ }^{109}$

De fato, em março, na $X$ conferência da Organização dos Estados Americanos (OEA), John Foster Dulles conseguiu convencer a maioria dos delegados a assinar a resolução que justificava a intervenção armada em qualquer Estado membro que fosse "dominado pelo comunismo" e que constituísse uma "ameaça hemisférica". Apenas México e Argentina se abstiveram e a Guatemala votou contra. ${ }^{110}$

Com a máquina de propaganda de Washington funcionando a pleno vapor, o acordo da CIA com a igreja guatemalteca e vários conflitos e incidentes se espalhando pelo país, foi fácil criar o clima favorável para enfrentar o que era chamado pela elite conservadora de tentativa de instalação de um ditadura comunista na América Central. Em 16 de junho, mercenários norte-americanos deram início ao bombardeio da Guatemala e em 18 de junho, Castillo Armas entrou no país.

Até então, a única ação concreta do governo guatemalteco foi fazer um protesto diplomático e apresentar seu caso ao Conselho de Segurança das Nações Unidas. Porém, com a pressão pessoal de Eisenhower e Dulles sobre a França e Grã-Bretanha, o conselho não aprovou uma investigação pela ONU. Em 3 de julho, Castillo Armas, ao lado de Puerifoy, entra na Cidade da Guatemala, depois que os próprios chefes militares guatemaltecos obrigaram Arbenz a renunciar. ${ }^{111}$

\footnotetext{
${ }^{109}$ ANDERSON, Jon Lee. Che uma biografia. Rio de Janeiro: Objetiva, 1997. p 154-186

${ }^{110}$ Idem.

111 Idem.
} 
No livro Polícia Política: relações EUA-América Latina, a pesquisadora norteamericana Martha Huggins relaciona documentos da CIA e em outros do FBI (Bureau Federal de Investigação), OPS (Seção de Segurança Pública, - a partir de 1990 designada ICITAD: Programa Internacional de Ajuda ao Treinamento em Investigação Criminal) que demonstram como os EUA constituíram um sistema de repressão e tortura em países da América Latina, África e Ásia através do treinamento e da montagem de polícias.

Data-se de 1898 o primeiro registro de treinamento norte-americano das polícias latino-americanas. Considerando-se somente a América Latina, nas três primeiras décadas do século $\mathrm{XX}$ os EUA inseriram e constituíram forças policiais em seus próprios territórios nas Grandes Antilhas e na América Central. Essas forças policiais ajudaram a manter o domínio norte-americano sobre Cuba, Porto Rico e Ilhas Virgens e a vigiar a construção do Canal do Panamá e sua operação pelos Estados Unidos. Mais tarde, seria exatamente no Panamá que os EUA construiriam sua "Escola das Américas", especializada no treinamento das polícias políticas.

Durante e logo após a Segunda Grande Guerra, temendo ameaças aos seus interesses na América Latina, os EUA transformaram o envolvimento com as polícias nativas em uma maneira de coletar informações que ajudassem a "proteger" o Ocidente contra as atividades da organização comunista e da espionagem fascista.

Nos anos seguintes à Segunda Grande Guerra, o treinamento das polícias latinoamericanas foi quase unicamente dedicado a combater a ameaça - que se julgava eminente - da revolução de esquerda e do levante de guerrilhas armadas, urbanas e rurais. O receio da potência norte-americana era que as polícias locais não estivessem preparadas organizacional e ideologicamente para enfrentar as supostas ameaças concebidas pelos EUA. A Guerra Fria alimentava este discurso estimulando umaa ideologia de segurança nacional, em nome da qual, qualquer atitude era aceita: seqüestro, tortura, espancamento, incentivo a esquadrões da morte e "desaparecimento" de inimigos políticos.

Em 1985, o governo Reagan instituiu o treinamento de polícias estrangeiras, de modo mais eficaz, para combater o que ele chamava de "terrorismo" nicaragüense e 
cubano. Em 1986, a CIA se auto-intitulou a polícia norte-americana na guerra contra o terrorismo. Os militares norte-americanos e conselheiros da CIA começaram a treinar unidades policiais "antiterrorismo" na Costa Rica, El Salvador, Honduras e Guatemala. ${ }^{112}$

Estas idéias mantiveram-se fortes até a década de 1990, quando o fim da Guerra Fria deu lugar a um discurso do antiterrorismo, do controle do narcotráfico e do crime organizado. Agora, o inimigo não era mais o "perigo vermelho vindo do leste" e sim os árabes terroristas, os fundamentalistas islâmicos, os narcotraficantes da Colômbia e os criminosos dos bairros pobres.

No Brasil, especificamente, esse discurso percorreu o mesmo caminho. Dos comunistas, passaram aos criminosos (assaltantes de bancos, seqüestradores); aos narcotraficantes, simbolizados pelos morros cariocas; às "minorias" sociais (negros, nordestinos, homossexuais) e movimentos sociais, como grevistas ou o MST. ${ }^{113}$

Washington justificava a ajuda a polícias estrangeiras com a lógica de que as tornaria mais democráticas, menos violentas e corruptas e mais profissionais. Isso poderia, de início, favorecer a imagem dos EUA no cenário internacional. No entanto, a verdadeira intenção da Casa Branca era outra. À medida que os Estados Unidos treinavam polícias estrangeiras, podem instalar infra-estruturas de informação e controle social para proteção e fortalecimento de sua posição. Assim, conforme as hegemonias centralizadoras do período da Guerra Fria foram sendo substituídas pela descentralização pós queda do Muro de Berlim, cresceu o que Huggins chama de "O Império da Lei”. ${ }^{114}$

O objetivo da ajuda a polícias estrangeiras continua sendo o de transformá-las em "correias de transmissão" da política externa dos EUA e dos interesses econômicos e políticos norte-americanos no exterior. Com o caminhar desse processo, os Estados Unidos penetram nos países estrangeiros através de seus sistemas policiais, tornando as polícias apêndices da política externa norte-americana.

\footnotetext{
${ }_{112}$ HUGGINS, Martha K. Polícia e Política: relações EUA/América Latina.São Paulo: Cortez, 1998.

${ }^{113}$ DEPOIMENTO de Paulo Sérgio Pinheiro, presidente do Núcleo de Estudos da Violência da USP (NEV/USP) a Alexandre Barbosa em 1999.

${ }^{114}$ HUGgins, Martha K. Polícia e Política: Op. Cit.
} 


\section{2 - A americanização pela sedução}

Antônio Pedro Tota ${ }^{115}$ mostra que, durante a Segunda Guerra Mundial, para uma parte da burguesia e da burocracia norte-americana, essa estratégia intervencionista não funcionaria. De acordo com Tota, as máquinas de guerra e de propaganda nazistas pareciam invencíveis aos olhos de homens como o megaempresário e multimilionário Nelson Rockefeller. O avanço do nazismo para as regiões de influência norte-americanas, como a América Latina, dificilmente seria contido, já que o continente vivia uma onda de governos nacionalistas, originados do processo de quedas em dominó das repúblicas latinoamericanas após a crise de 1929. Governos como o de Vargas pareciam ora pendentes para o Eixo, ora pendentes para os aliados.

O Brasil, além de exercer profundamente essa política de pêndulo entre o Eixo e os aliados, reunia outras características importantes. Havia uma grande colônia alemã fixada no sul e que era alvo da propaganda nazista. Por seu tamanho e posição geográfica, seria uma base importante para controle do Atlântico sul. Além disso, o extremo leste do Brasil é o ponto da América Latina mais próximo do norte da África, por onde o Eixo conseguia avançar rapidamente sem que os aliados pudessem resistir.

115 TOTA, Antonio Pedro. O Imperialismo Sedutor. São Paulo: Companhia das Letras, 2000. 
Era fundamental, portanto, que o Brasil se tornasse aliado dos Estados Unidos na luta contra o nazismo. Nelson Rockefeller vislumbrava que a tomada de posição do Brasil não se daria pela intervenção, mas pela sedução. De acordo com Tota, Rockefeller entendia que se o governo, a população e as instituições brasileiras considerassem que o modelo de desenvolvimento capitalista norte-americano era o ideal, o Brasil se tornaria um aliado natural dos EUA.

Para levar a cabo esse projeto de convencimento e sedução do Brasil, Rockefeller criou uma verdadeira fábrica de ideologias, uma agência chamada Office of Inter-American Affairs (OCIAA). Por meio dessa agência, o presidente norte-americano Roosevelt conseguiu implantar a Política da Boa Vizinhança e trouxe o Brasil como aliado na guerra contra o Eixo.

Rockefeller acreditava que o futuro dos negócios e empreendimentos norteamericanos na América Latina dependia da venda não só de produtos americanos, mas também do modo de vida americano. O sucesso no campo econômico dependia de uma base sólida no campo ideológico. Era necessário empregar todos os meios para consolidar a imagem do modelo a ser seguido, isto é, os Estados Unidos deveriam ser um paradigma.

O plano da agência para seduzir o Brasil consistia no uso de rádio, do cinema e de revistas que difundissem no Brasil o desenvolvimento econômico e cultural norte-americano, que mudassem a imagem do norte-americano entre os brasileiros e que, ao mesmo tempo, convencessem os empresários norte-americanos de que valeria a pena "investir" nos países latino-americanos depois que acabasse o esforço de guerra.

As revistas que mostravam o esforço de guerra dos EUA eram produzidas em inglês, português e espanhol e retratavam como a tecnologia desenvolvida para ser usada nos campos de batalha chegava às donas-de-casa por meio de eletrodomésticos e alimentos enlatados. No trecho transcrito a seguir, Tota relata a força do departamento de imprensa do escritório de Rockefeller.

"A estratégia propagandística do Office incluía a publicação de brochuras, panfletos e revistas. Dentre estas, a mais difundida foi Em Guarda, revista no estilo da Life Magazine (1940) [...] A revista veiculava uma imagem dos Estados Unidos como fortaleza da 
democracia continental [...] A Divisão de Imprensa era uma das maiores do Office. Tinha cerca de duzentos funcionários trabalhando em tempo integral. [...] Exerciam quase todas as funções, desde o envio de radiofotos para os maiores jornais do Brasil até a colaboraçãona distribuição de documentos oficiais, discursos e panfletos." 116

Outra revista muito influente à época era Seleções do Reader's Digest, que continha textos de fácil assimilação, era editada em português nos Estados Unidos, em papel de qualidade e com ilustrações. O objetivo era conquistar o brasileiro médio urbano o latino-americano "oficial" - por meio de anúncios e artigos que celebravam o American way of life.

A importação do conteúdo estrangeiro é um dos embriões da dependência da imprensa brasileira do material vindo das agências norte-americanas. Porém, ainda mais grave é a influência total no modo de produção jornalístico. Adelmo Genro Filho relata a importação do modelo da pirâmide invertida, que abre o texto com o lead, sintetização no primeiro parágrafo do que é considerado essencial na notícia, uma técnica norte-americana.

"A primeira notícia redigida segundo a técnica da 'pirâmide invertida' teria aparecido no The New York Times em abril de 1861. A partir da segunda metade no século XX, alguns dos mais importantes periódicos latino-americanos passaram a publicar notícias das agências norte-americanas, redigidas segundo esse modelo. Nesse período, essa técnica se espalhou gradativamente, tendo chegado no Brasil exatamente em 1950, pela iniciativa do jornalista Pompeu de Sousa." 117

A prática do lead, comum em todos os jornais, primeira recomendação das escolas de jornalismo e até exigência dos manuais de redação, se intensificou durante a enxurrada de noticiários norte-americanos despejados diariamente nos jornais e também nas rádios brasileiras.

Os programas de rádio eram produzidos pelos burocratas do OCIAA em conjunto com as grandes redes NBC e $A B C$ e transmitidos para o Brasil em ondas curtas. A programação era publicada nos jornais.

O radiojornal foi a primeira forma de programação aprovada em abril de 1941 pela agência norte-americana. Os programas recebiam investimentos de empresários norteamericanos que foram conscientizados de que deveriam ajudar a imagem dos EUA na ${ }^{116}$ Idem. Op. Cit. p. 55-56

${ }^{117}$ GENRO FILHO, Adelmo. O segredo da pirâmide - para uma teoria marxista do jornalismo.

Porto Alegre: Tchê, 1987. p. 183-202. 
América Latina. De acordo com um alto funcionário da NBC, os latino-americanos deveriam ser convencidos de que os EUA queriam criar e não explorar. ${ }^{118}$ Em 1941, o projeto de transmissão diária de um jornal falado para todos os países da América Latina recebeu uma verba inicial de 50 mil dólares. As primeiras edições destes programas foram feitas em parceria com a Columbia Broadcast System (CBS), retransmitidas pela American Telephone \& Telegraph (AT\&T) e distribuídas pela International Telephone \& Telegraph (IT\&T) para as estações espalhadas pela América Latina. No Brasil, no programa estatal Hora do Brasil, cinco minutos da programação eram cedidos para o OCIAA, que transmitia de Nova lorque. "Grande parte dos programas enfatizava as potencialidades dos americanos de resistirem, material e moralmente, ao avanço do Eixo. Outros programas se encarregavam de difundir entre nós o modo de vida americano [American way of life], amparando-se, quase sempre, nas músicas e nos filmes". ${ }^{119}$

O radiojornalismo norte-americano chegou ao Brasil antes do próprio projeto nacional de jornalismo para o novo veículo. O Repórter Esso, programa que inaugurou o sucesso do horário nobre (20h) pela Rádio Nacional era produzido primeiro por publicitários da agência de propaganda da multinacional de derivados de petróleo e depois por redatores brasileiros que traduziam as notícias produzidas pela United Press International (UPI), agência de notícias norte-americana. O modelo de jornalismo era o idealizado nos estúdios comandados pelo escritório de Rockefeller.

Da mesma forma isso se processava nos cinejornais. Até mesmo o cinema passava pela intervenção da agência de Rockefeller. Os burocratas da OCIAA abasteciam as produtoras de Hollywood com informações sobre a América Latina para que os filmes exibidos aqui não ferissem as culturas locais. Produções que fossem ambientadas na América Latina eram incentivadas. Foi neste processo de "intercâmbio" que surgiram personagens como Carmem Miranda e Zé Carioca.

\footnotetext{
118 TOTA, Antonio Pedro. Op. Cit. p. 76.

119 TOTA, Antonio Pedro. Op. Cit. p. 77.
} 
Carmem Miranda foi uma "criação" da indústria cultural norte-americana, primeiro no rádio, depois do cinema. No livro, Tota mostra ${ }^{120}$ como a cantora foi usada tanto para alimentar o processo de sedução do Brasil como para cativar a burguesia norte-americana. O personagem dos estúdios Disney, Zé Carioca, foi mais uma arma neste processo.

Mesmo com o trabalho da Agência, para os idealizadores da Política da Boa Vizinhança não importava a autenticidade da cultura das outras "Américas" difundida pelas rádios e pelo cinema (Carmem Miranda é prova disso, ou a brasileira se veste com turbante enfeitado de abacaxis, uvas e bananas?). O importante era que este processo contribuía para obter o alinhamento do Brasil com o esforço de guerra dos EUA.

Com a derrota da Alemanha no norte da África, com o sucesso da invasão aliada no norte da França e com a derrota dos alemães na URSS, a vitória aliada parecia ter hora marcada. Ao mesmo tempo, os trabalhos do OCIAA foram se esvaziando até que, com o final da Segunda Guerra ,não tinham mais sentido e a agência foi desfeita. A América Latina perdeu novamente o grande interesse que ganhou durante a guerra e voltou a ser um grande quintal, sujeito às antigas formas de intervenção.

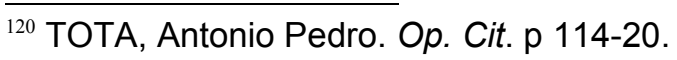


Entretanto, o estrago tinha sido feito. O Brasil estava não só seduzido, como americanizado. O American way of life estava implantado entre os brasileiros, todos sedentos pelo consumo de eletrodomésticos e da produção cultural norte-americana. Rapidamente, termos e expressões em inglês foram assimilados. Tota relata como o thumbs up, sinal de positivo indicado pelo polegar apontado para cima usado como comunicação entre os pilotos de caça e mecânicos, foi logo "mimetizado" pelos nordestinos que viviam próximo da base americana instalada em Natal.

Além de afetar diretamente os costumes e o linguajar dos brasileiros, este processo de sedução teve efeito ainda mais devastador no jornalismo brasileiro. A campanha de transmissão de programas de rádio, de produção de cinejornais e da proliferação de filmes coincide com o desenvolvimento da indústria jornalística no Brasil. Ao mesmo tempo em que o rádio ganhava força como meio de comunicação de massa (em 1931 o governo Vargas regulamenta o uso da publicidade em programas de rádio) e se formavam os profissionais habilitados a trabalhar nesse veículo, desembarcavam no país as esmeradas e caprichadas produções norte-americanas. As revistas norte-americanas concorriam com as nacionais, ganhando na produção e na qualidade gráfica. O radiojornal ainda não tinha surgido no Brasil quando o modelo chegou dos EUA.

Evidentemente, os padrões, as normas e as regras para se fazer jornalismo no Brasil foram estabelecidos com base no jornalismo norte-americano. É por isso que hoje o nosso jornalismo é uma cópia do jornalismo praticado nos EUA e que se utilizam tantos termos em inglês como lead, teaser, realease, press kit, off e copydesk.

A influência do modelo de jornalismo foi além da adoção do lead. Também dos EUA se adotou o princípio do jornalismo informativo como produto de venda da empresa capitalista. Na análise de Adelmo Genro Filho:

\footnotetext{
"Foi na segunda metade do século XIX que, na Europa e nos Estados Unidos, ocorreram grandes transformações na imprensa, coincidindo com a expansão mundial do capitalismo e o aparecimento de inovações tecnológicas ligadas direta e indiretamente à reprodução e circulação das informações. Nesse período, o jornalismo sofreu modificações profundas. [...] Estava nascendo o jornalismo informativo ou, se preferirmos, o "jornalismo por excelência". A idéia simplista de que "os fatos são sagrados" e de que a opinião pertence a uma órbita autônoma, tornou-se a expressão prosaica do que viria a ser a " ideologia da objetividade",
} 
marcando o fim de uma época na qual a notícia sempre se escrevia entremeada de comentários e salpicada de adjetivos. Também os temas da notícia vão mudando gradualmente. Ao lado das questões políticas, econômicas, literárias ou científicas, surgem as informações sobre acontecimentos banais que, cada vez mais, despertam interesse nos novos leitores e ocupam um espaço crescente nos jornais. Na América Latina, esse processo está ligado, como indica Fernando Reyes Matta, à dependência informativa que se gerou com base na integração e subordinação econômica, política e cultural aos Estados Unidos. Desde o final do século XVIII, quando nasceu - diz o referido autor -, a imprensa latino-americana era entendida como uma corrente de opinião, tendo se constituído em expressão significativa das lutas pela independência e libertação nacional. No século passado, quando a imprensa norteamericana já tinha um caráter sensacionalista, a imprensa latino-americana seguia seu estilo literário e opinativo. A partir dos anos trinta, com a presença mercante do rádio, começa a impor-se o conceito de notícia objetiva. Principalmente pela integração econômica, cultural e política crescente da América Latina, o que se produzia era uma crescente dependência informativa. Em 1920, a United Press (hoje UPI) conseguiu seu primeiro acordo com o diário La Prensa de Buenos Aires. [...]Na verdade, o processo de expansão imperialista dos Estados Unidos e a conseqüente subordinação econômica, política e cultural da América Latina coincide, em linhas gerais, com o processo de urbanização e industrialização dos países mais adiantados do continente. Para esses países - entre os quais se inclui o Brasil - a subordinação ao imperialismo correspondeu a uma forma de integração no contexto mundial do capitalismo e da civilização que ele patrocinou. Por isso, em função também de condições internas e não apenas externas, o "conceito objetivo de notícia" acabaria se impondo - ainda que mais tarde -, por derivar de necessidades sociais geradas pelo desenvolvimento capitalista. Por trás dessa recusa do "conceito objetivo de notícia", que orienta o fazer jornalístico contemporâneo, está a tese de que o próprio jornalismo não passa de um epifenômeno do capital." 121

A substituição do jornalismo político-literário pelo jornalismo empresarial - processo iniciado na segunda metade da década de 30 e que ganhou força na década de 1950 proporcionou o abandono da tradição da polêmica e da crítica. O que surgiu foi um jornalismo que "privilegiava a informação, (transmitida 'objetiva' e 'imparcialmente' na forma de notícia) e que a separava (editorial e graficamente) do comentário pessoal e da opinião. [...] Na estruturação da notícia, o jornalismo adotou as técnicas norte-americanas do lead e da pirâmide invertida. Símbolo máximo do jornalismo moderno, o lead veio substituir o "nariz de cera", texto introdutório longo e rebuscado, normalmente opinativo, que antecedia a narrativa dos acontecimentos e que visava ambientar o leitor" ${ }^{122}$

Como copiamos o modelo de jornalismo norte-americano, adotamos também os óculos usados por eles. E nos óculos norte-americanos a América Latina não passa de um quintal. Se mesmo quando o continente representava algum interesse, não havia grande

\footnotetext{
${ }^{121}$ GENRO FILHO, Adelmo. O segredo da pirâmide - para uma teoria marxista do jornalismo. Porto Alegre: Tchê, 1987. p. 165-82.

${ }^{122}$ RIBEIRO, Ana Paula Goulart. Jornalismo, literatura e política: a modernização da imprensa carioca nos anos 1950. Estudos Históricos, Mídia, n31, Rio de Janeiro: CPDOC/FGV, 2003.
} 
preocupação em compreender a complexidade cultural dos latino-americanos, vide Carmem Miranda e o filme Saludo, Amigos!-, após o término dos trabalhos da OCIAA a América Latina voltou a cair no mais profundo esquecimento.

Os veículos de comunicação têm correspondentes nos EUA não só porque lá é o centro econômico do capitalismo, mas também porque lá é considerada a grande Meca do que se entende por jornalismo. Assim, pode-se não manter correspondente em nenhum outro país, mas é fundamental que a sucursal de Nova lorque esteja em atividade. Hoje, os EUA são sinônimo de mercado, de referência comercial, cultura e política para a América Latina Oficial.

Os meios de comunicação foram usados pedagogicamente para americanizar o Brasil. "Houve um projeto de americanização, quer dizer, ações deliberadas e planejadas visando a um objetivo. A existência desse projeto não exclui o processo de americanização conduzido pelas forças de mercado. Ao contrário, há evidências da imbricação dos dois processos". ${ }^{123}$

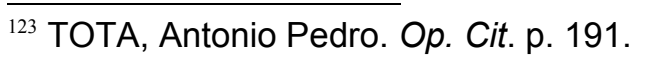




\section{Solidão em tempos de globalização: globalização dos mercados e não dos países}

Se um extraterrestre descesse num shopping center, não saberia se está em São Paulo ou em Cingapura. Nada é mais norte-americano que um shopping center. Beatriz Sarlo descreve um shopping de maneira tão universal que pode ser perfeitamente um shopping de São Paulo, Buenos Aires ou Santiago. ${ }^{124}$ Dentro dele não se sabe se é dia ou noite, se está frio ou calor. Pelos nomes das lojas, pelas placas de liquidação dizendo $50 \%$ off e pelas grifes vendidas não se sabe que língua se fala. Não há crianças de rua, assaltos ou mendicância. É a completa perda de tempo e espaço dedicado ao consumo e ao exercício de qualquer outro tipo de atividade. Tudo pode ser encontrado no shopping: do veterinário, passando pelo sapateiro, banco, restaurantes, pedicure, academia, laboratório de análises clínicas, correios e até escolas. Os shoppings também são responsáveis pela degradação dos centros das cidades que ficam estigmatizados como locais de consumo popular e onde o consumidor pode estar sujeito a chuvas, frio, assaltos e ao incômodo de "ver o que é feio".

O shopping é construído para esquecer a cidade, para fazer esquecer a História. A arquitetura dos novos prédios não respeita a arquitetura do que está em volta (ou pior, do lugar que foi derrubado para que aquele fosse construído). Os shoppings se multiplicam tanto nas cidades brasileiras que tornam ainda mais difícil o sentimento de ser latinoamericano. Parecemos mais norte-americanos do que latino-americanos comprando grifes estrangeiras, comendo em fast-foods. Sarlo afirma que "a rapidez com que o shopping se impôs na cultura urbana não teve precedentes em nenhuma outra mudança de costumes [...] onde as instituições e a esfera pública já não podem construir marcos erige-se um monumento baseado justamente na velocidade do fluxo mercantil”125.

O centro de compras, num processo que transcende a fetichização, vira o templo do consumo e transforma cidadãos apenas em consumidores. Francisco de Oliveira, ao descrever a exploração do trabalhador no século XXI - em que o capital utiliza o trabalho

${ }^{124}$ SARLO, Beatriz. Cenas da Vida Pós-Moderna. Rio de Janeiro: Editora UFRJ, 1997.

${ }^{125}$ SARLO, Beatriz. Op. Cit. p 22. 
abstrato dos trabalhadores informais como fonte de produção de mais-valor -, aponta o setor de serviços como um dos grandes responsáveis pela separação entre a exploração relativa e absoluta: "cria-se uma espécie de 'trabalho abstrato virtual'. As formas 'exóticas' desse trabalho abstrato virtual estão ali o trabalho aparece como diversão, entretenimento, comunidade entre trabalhadores e consumidores: nos shopping centers". ${ }^{126}$

Beatriz Sarlo segue um raciocínio semelhante sobre a fetichização:

"Quando nem a religião, nem as ideologias, nem a política, nem os velhos laços comunitários, nem as relações modernas da sociedade podem oferecer uma base de identificação ou um fundamento suficiente para os valores, ali está o mercado, um espaço 'universal e livre', que nos dá algo para substituir os deuses desaparecidos. Os objetos são nossos ícones porque podem criar uma comunidade imaginária (a dos consumidores, cujo livro sagrado é o advertising e cujo ritual é o shopping spree, e cujo templo é o shopping, sendo a moda seu código civil)." ${ }^{127}$

A América Latina Oficial é uma comunidade de consumidores, e é para esses consumidores que os meios de comunicação são estruturados. Portanto, quando Canclini afirma que há uma relação de contrato entre os meios de comunicação e os receptores relação repetida exaustivamente pelos editores dos jornais -, ele se refere a esse processo, que é excludente e esconde a verdadeira contratação. Nessa relação, na verdade, os contratantes não são os receptores que exigem notícias do "centro comercial" mas os agentes de mercado, que praticamente sacralizaram o consumo e usam os meios de comunicação como gigantescos catálogos do que pode ser consumido.

O mercado ocupou o vazio deixado pela perda de identidade. No lugar de se sentirem latino-americanos os cidadãos são levados a sonhar com os objetos do mercado. Quem não tem como realizar estes sonhos é excluído - não só do mercado e de toda sua simbologia (peças publicitárias e meios de comunicação ) mas também da cidade como um todo. Ou seja, é excluído das políticas públicas de lazer, educação, saúde, cultura, habitação. A administração pública trabalha a favor dos incluídos no mercado. "Hoje o sujeito que pode entrar no mercado, que tem o dinheiro para intervir nele como consumidor é uma espécie de colecionador às avessas. Em vez de colecionar objetos, coleciona atos de

\footnotetext{
126 OLIVEIRA, Francisco. Op. Cit. p 137.

${ }^{127}$ SARLO, Beatriz. Op. Cit. p. 28-9.
} 
aquisição de objetos." ${ }^{128}$ A grande imprensa é o órgão responsável pela alimentação destes consumidores às avessas.

Veja São Paulo, encarte da revista Veja, conhecida por Vejinha, é o melhor exemplo de como um meio de comunicação é construído para servir de catálogo para a elite, mas é vendido ideologicamente como leitura obrigatória para TODA a cidade.

Na edição de 2 de março de 2005, selecionada aleatoriamente entre as várias edições semanais, Vejinha destaca na manchete "Jóias para a Casa" o crescimento e sofisticação das lojas de decoração para casa, onde um lustre chega a custar $\mathrm{R} \$ 84$ mil. $\mathrm{Na}$ matéria "Mistérios da Cidade" a reportagem mostra os lugares da cidade que vendem um copo com água por até $\mathrm{R} \$ 5,50$ como o restaurante Fazano e o Hotel Renaiscense. Em seguida, no painel de notas sobre a cidade chamado "Terraço Paulistano" uma nota sobre uma pesquisa de mídia feita por meio de outdoors, uma sobre o aluguel do prédio do Banco Santos e outra, singular, sob a manchete "Paulistanos chipados": trata-se do uso de chips implantados em paulistanos receosos de seqüestro.

O próximo conteúdo "editorial" mostra a assédio dos paulistanos a bares, casas noturnas, lojas e shoppings freqüentados preferencialmente por homossexuais. Em seguida, a matéria de capa, sob o chapéu "Consumo" mostra almofadas de mais de R\$ 5 mil. A seção "Noite" descreve os bares badalados que fazem festas no estilo reggae. Outra seção, "Estilo", dá dicas da modelo Caroline Bittencourt - que virou celebridade dias antes por ter sido expulsa do casamento midiático entre o jogador Ronaldinho e a modelo Daniela Cicarelli. As seções "Compras" e "Roteiro" não escapam do tom: dicas de lugares para se gastar. Para encerrar, a seção "Perfil" traz o "padre-celebridade" Antonio Maria. O gancho, no entanto, não é religioso como se nota pelo olho escolhido: "Da viagem de Ana Maria Braga a Portugal ao casamento de Ronaldinho e Cicarelli, o Padre Antonio Maria está em todas". Isto é o editorial. Soma-se a ele as dezenas de anúncios de relógios, restaurantes, grifes e bancos.

${ }^{128}$ SARLO, Beatriz. Op. Cit. p. 26. 
Não é preciso o menor esforço para compreender que a Vejinha é um grande catálogo de consumo feito para a elite paulistana. Pelo bordão de sua mãe, Veja, de que é "indispensável", subentende-se que a Vejinha também o seja. O mercado define o que é dispensável. Dispensáveis seriam, para a Vejinha, todos os excluídos da cidade, todos aqueles que não podem comprar os produtos anunciados em suas páginas e tampouco teriam como viver no mundo retratado por suas matérias. Da mesma maneira funcionam a Playboy, Vip, Caminhos da Terra, Nova, Cláudia, Quatro Rodas.

Para não ficar apenas na Editora Abril é possível pegar aleatoriamente outra revista semanal encartada em uma publicação do Grupo Folha. A Revista da Folha, encarte dominical do jornal Folha de S.Paulo, segue o mesmo procedimento. Na edição de 3 de maio de 1998 a matéria de capa destaca as brigas de condomínio. Mas não qualquer briga, como adverte o olho: "Justiça recebe cerca de 60 casos de brigas de vizinhos por mês, que acontecem inclusive nos prédios mais luxuosos de São Paulo". Os entrevistados na matéria (nomes como Chasseraux, Hoffmann, Gerodetti, Exman) que moram em grandes apartamentos - e até coberturas - na Vila Mariana ou Pinheiros. O maior condomínio brasileiro, o Copan, foi incluído pois se assim não fosse seria já um assassinato do jornalismo, não bastasse o "esquecimento" dos outros milhares de condomínios que poderiam ser objeto da matéria.

Entre os anúncios, lojas de decoração (Tok\&Stok - que em 1998 anunciava uma garrafa térmica por $\mathrm{R} \$ 52,00)$, as grifes Yves Saint-Laurent, Fórum, clínicas de estética e dezenas de outros brigam com matérias de comportamento e estilo que sugerem óculos Gianfranco Ferre, escarpim e carteira de paetês. Na seção "Turismo" o gancho são os guias de viagem lançados na XV Bienal do Livro. A revista fez uma pesquisa - nas palavras da própria matéria - e selecionou como melhores os de Paris, Madri, Miami e Orlando. Como o dia das mães se aproximava, a revista ajudava os leitores que queriam fugir dos presentes tradicionais montando um roteiro de viagem: África do Sul, Serras Gaúchas, Cancun, St. Maarten (Caribe), Parati, Bonito e Rio de Janeiro. Essa é a revista da Folha de S.Paulo, que se proclama um jornal plural. 
O que mais impressiona é o silencio de parte da intelectualidade e da academia a este quadro horroroso e perceptível a olho nu. E quando não há silêncio, há explicações estapafúrdias ou incompletas. Para Beatriz Sarlo: "os neopopulistas de mercado, deslumbrados com o cruzamento entre os restos culturais populares e os meios de massa, fecham os olhos diante das desigualdades de acesso aos bens simbólicos e, em conseqüência disto, preferem não se referir à dominação econômica e cultural". ${ }^{129}$

\subsection{Globalização e reação}

Um leitor poderia se perguntar: como se pode falar de distanciamento da América Latina se agora é a época da globalização e o mundo ficou menor, ao alcance de uma tecla do computador? A resposta, novamente, é simples. O que se globalizou foi o consumo e não os países. A idéia de nação se desfaz diante da noção de extraterritorialidade, afinal o Big Mac em Buenos Aires é o mesmo Big Mac de Maceió, de Belo Horizonte ou de Lima. O Brasil não está globalizado com a América Latina, mas a outros centros de consumo. Aliás, os outros centros históricos com os quais o Brasil poderia se conectar vão sendo aos poucos destruídos pelos shopping centers. Não há intercâmbios de histórias e culturas, mas invasão de marcas e valores norte-americanos. Essa invasão foi incentivada pela grande arte popular do século XX: o cinema de Hollywood.

Durante as entrevistas realizadas com os jornalistas para esta pesquisa, Heródoto Barbeiro $^{130}$ afirmou que o jornalismo só se dedica aos lugares com os quais há relações comerciais. Diante dessa afirmação poder-se-ia acreditar que com a consolidação do Mercosul, a América Latina teria chances de ganhar espaço no jornalismo. Porém, o Mercosul não se afirmou como uma integração de países, mas sim como a globalização de mercados.

\footnotetext{
${ }^{129}$ SARLO, Beatriz. Op. Cit. p 119-20.

${ }^{130}$ DEPOIMENTO de Heródoto Barbeiro, editor chefe da Rádio CBN a Alexandre Barbosa em janeiro de 2003.
} 
Antes do episódio de 11 de setembro de 2001, o neoliberalismo e toda sua indústria simbólica estavam em defensiva. Gênova, Seatle e outras cidades do centro do capitalismo observavam o crescimento das passeatas e manifestações contra a globalização. Infelizmente, os ataques às torres gêmeas serviram de mote para o endurecimento da repressão. A mídia teve argumento para colocar os EUA como vítimas de uma orquestração mundial. A "democracia" estava em perigo e os "paladinos da liberdade" receberam permissão mundial para desencadear uma série de ataques criminosos pelo planeta. Não que as manifestações antiglobalização tenham cessado, mas os holofotes da mídia não precisavam mais se preocupar com elas.

O surgimento do Fórum Social Mundial, em oposição ao Fórum Econômico de Davos simboliza essa reação. As primeiras edições foram combativas. Mães da Praça de Maio, em teleconferência, criticam os banqueiros pelos milhões de crianças que morrem de fome em todo o mundo. Saramago, Galeano, zapatistas, Chomsky, Bovet, Emir Sader e milhares de organizações não governamentais, movimentos sociais e partidos de esquerda propondo soluções para um novo mundo. O Fórum parte para sua sexta edição sem conseguir sair da proposta e partir para ação. Contudo, mais importante é sua manutenção, sua persistência em provar que outro mundo é possível.

Durante a década de 1990 a América Latina ficou mergulhada no pensamento único de que o neoliberalismo era a única solução para sair da crise social e econômica. Todas as iniciativas neoliberais apenas aprofundaram as diferenças e exclusões. Felizmente, houve conflitos iniciando com o bravo levante dos zapatistas em 1994, na selva de Chiapas. Os movimentos sociais latino-americanos ganharam as manchetes dos jornais com as ações do MST no Brasil e provocaram polêmica com o governo de Chavez na Venezuela.

Para Emir Sader, a América Latina passa por um conflito entre o velho e o novo:

"O velho insiste em sobreviver por meio de governos que mantêm e reproduzem as desumanas e antidemocráticas políticas de ajuste fiscal, priorizadas em relação às políticas sociais. Isolados em relação às necessidades prementes da massa da população, se apóiam no capital especulativo, nos organismos financeiros internacionais e no monopólio privado da mídia, que os ampara e sustenta. [...]O novo revela sinais da força já acumulada para 
construir alternativas ao neoliberalismo e ao belicismo. O novo começou a surgia há muito tempo - desde o grito de Chiapas dos zapatistas, em 1994 -, mas tomou novo impulso quando os camponeses bolivianos impediram a privatização da água e derrubaram o presidente que a promovia, construindo uma força política social alternativa ao governo. Surge quando os movimentos sociais latino-americanos - a começar pelo MST -, lutam pela reforma agrária, contra os transgênicos e pela segurança alimentar. O novo está presente na vitoriosa reestruturação da dívida externa Argentina, realizada por Nestor Kirchner. O novo se expressa na eleição da Frente Ampla para dirigir o Uruguai, na vitória de Hugo Chavez no referendo venezuelano, na política de integração latino- americana - renovada e fortalecida na reunião de Lula, Kirchner e Hugo Chavez, em Montevidéu, para programar cúpulas dos ministérios sociais, de energia e econômicos dos seus governos e dos que queiram se somar a essas iniciativas.

Também fazer parte do novo as propostas de criação de uma televisão pública dos paises do continente, de integração das empresas petrolíferas da América Latina e do Banco da Semente, para proteger o nosso patrimônio natural. O novo está presente nos acordos estratégicos assinados entre os governos de Brasil, Venezuela, Cuba, Argentina, Uruguai, entre si e com China, Irã, Rússia e Espanha, projetando uma nova inserção internacional do continente." 131 
Interessante notar que, no início do século XX, José Carlos Mariátegui já alertava para a necessidade de integração econômica da América Latina no ensaio La Unidad Latinoamericana publicado em 1929. "Lo que separa y aísla a los países hispanoamericanos, no es esta diversidad de horario político. Es la imposibilidad de que entre naciones incompletamente formadas, entre naciones apenas bosquejadas en su mayoría, se concerte y articule un sistema o un conglomerado internacional. En la historia, la comuna precede a la nación. La nación precede a toda sociedad de naciones.(...) Entre los pueblos hispanoamericanos no hay cooperación; algunas veces, por el contrario, hay concurrencia. No se necesitan, no se complementan, no se buscan unos a otros. Funcionan económicamente como colonias de la industria y la finanza europea y norteamericana". ${ }^{132} \mathrm{O}$ triste é reconhecer que quase um século depois, o cenário não se alterou. Do contrário, apenas se acentuou.

Há consenso entre todos os que estudam a América Latina, uma eterna esperança de solução da crise. Solução que passa pela mobilização, pela união dos movimentos sociais e culturais, pelo fortalecimento da imprensa alternativa, pelo crescimento da intelectualidade militante e crítica, do incremento da educação a favor de um mundo baseado na solidariedade, e não na individualidade. O novo caminho da América Latina passa pela verdadeira união dos países. União que pode começar como reação à globalização mas que pode colocar a região no centro das atenções.

Estudado o ambiente sócio-histórico em que se insere a América Latina, resta conhecer a realidade das redações: como funcionam os óculos dos jornalistas e das empresas jornalísticas, as influências no modo de produção jornalístico e o processo de formação do jornalista, como será visto no próximo capítulo.

132 [1924] MARIÁTEGUI, José Carlos. Textos Básicos. Lima, Peru: Fondo de Cultura Económica, 1991. p. 363. 


\section{Capítulo III}

Cantor de oficio

(Miguel Ángel Morelli)

Mi oficio de cantor es el oficio De los que tienen guitarras en el alma

Yo tengo mi taller en las entrañas Y mi única herramienta es la garganta.

Mi oficio de cantor es el mas lindo

Yo puedo hacer jardín de los desiertos

$Y$ puedo revivir algo ya muerto

Con solo entonar una canción.

Yo canto siempre a mi pueblo

Porque del pueblo es mi voz

Si pertenezco yo al pueblo

Tan sólo del pueblo será mi canción.

Nadie debe creer que el cantor

Pertenece a un mundo extraño

Donde todo es escenario y fantasía

El cantor es un hombre más que anda

Transitando las calles y los días

Sufriendo el sufrimiento de su pueblo

Y la tiendo también con su alegría.

Mi oficio de cantor es tan hermoso

Que puedo hacer amar a los que odian

Y puedo abrir las flores en otoño

Con solo entonar una canción.

O jornalista é um intelectual, como definiu Antonio Gramsci em Os Intelectuais e a Organização da Cultura. Nestas notas, Gramsci dá a receita de como deveria ser o jornalismo que ele chama de integral, ou seja, aquele que "pretende satisfazer todas as necessidades de seu público, mas pretende também criar e desenvolver estas necessidades e, conseqüentemente, em certo sentido, criar seu público e ampliar progressivamente sua área. [...] É dever da atividade jornalística seguir e controlar todos os movimentos e centros intelectuais que existem e se formam num país". ${ }^{133} \mathrm{E}$ é essa a definição de jornalista que esta dissertação assume.

${ }^{133}$ GRAMSCI, Antônio. Os intelectuais e a organização da cultura. Rio de Janeiro: Civilização, 1968. p. 163-64. 
Diante dessa função, como estão preparados os colegas jornalistas para exercê-la? Há dois lados nessa discussão: de um, o distanciamento do jornalista do mundo real, o uso dos óculos para a seleção de notícias e a formação deficitária desde a educação básica até a superior; de outro, as difíceis relações de trabalho numa redação e o uso do material das agências internacionais como forma de baratear a produção jornalística.

\section{Os óculos dos jornalistas}

O pai desta definição é Pierre Bourdieu. Para o sociólogo francês, os jornalistas, condicionados pelas propensões inerentes à profissão, pela sua visão de mundo, sua formação, pela lógica da profissão e por suas disposições, selecionam na realidade algo que Ihes pareça particular em função de categorias de percepção. Para explicar estas categorias - estruturas que organizam o percebido, determinando o que se vê e o que não se vê - é usada a metáfora dos óculos. "Os jornalistas têm óculos especiais a partir dos quais vêem certas coisas e não outras; e vêem de certa maneira as coisas que vêem. Eles operam uma seleção e uma construção do que é selecionado" ${ }^{134}$. Esses óculos são formados não só pelas lógicas da profissão, mas também por todos os outros fatores descritos anteriormente: pela História da América Latina, pela visão do "outro" como inferior e atrasado, pela herança colonial, pela americanização da cultura, pela ligação "orgânica" dos jornalistas com a América Latina Oficial e também pelas relações de trabalho nas redações e a opção em se fazer um jornalismo "informativo" na aparência, voltado para a venda em massa de jornal como produto de veiculação de anúncios publicitários.

${ }^{134}$ BOURDIEU, Pierre. Sobre a Televisão. Op Cit. 
As temáticas das matérias jornalísticas, na média, são comuns e a pauta compartilhada. São poucas as reportagens que saem do senso comum. A esse processo Bourdieu chama de circulação circular da informação e Ciro Marcondes Filho de autoreferência. Os jornais passam boa parte do tempo citando uns aos outros e o acirramento da concorrência faz com que se pautem mutuamente. Nenhum veículo quer deixar seu noticiário órfão de determinada pauta - por mais banal que ela seja - não pela preocupação de informação mas pelo receio de perder audiência, o que acarreta diminuição da verba publicitária.

Na visão do jornalista José Arbex Jr., este fenômeno ocorre "muito mais pela inércia preconceituosa e ignorância intelectual dos jornalistas do que por uma vontade política consciente. Muitos editores simplesmente não se dão conta de possíveis alternativas, desde que fossem questionados os pressupostos sobre os quais se baseiam as construções colocadas em circulação pelas agências internacionais e outras matrizes produtoras de narrativas". 135

Na definição de Bourdieu, uma informação que circula em círculos é mais fácil de ser digerida pelo público e alcança maior índice de audiência. A informação que chega ao receptor é homogeneizada, pois todos os veículos de comunicação sofrem as mesmas restrições, são orientados pelas mesmas pesquisas de opinião e audiência e têm os mesmos anunciantes. Os jornalistas se informam com outros jornalistas. O que é notícia na TV deve, quase obrigatoriamente, ser notícia na rádio, no jornal, no semanário, na Internet, pois um veículo não pode deixar de noticiar o que outro noticiou. No caso brasileiro, a manchete do Jornal Nacional será a manchete dos diários paulistas no dia seguinte, pauta da reportagem nas rádios, assunto da entrevista do meio-dia em todos os veículos e, se nada de espetacular acontecer, a capa das revistas semanais.

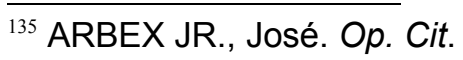


Esta circulação circular da informação, gerada por jornalistas que já selecionam as notícias a partir dos óculos que usam, ou seja, de categorias de pensamento que definem o que deve ser notícia, produz a censura. Para Bourdieu não há discurso ou ação que não se submeta a essa prova de seleção jornalística, a essa censura que os jornalistas exercem, muitas vezes sem tomarem noção disto. A censura dos jornalistas é feita ao "reter apenas o que é capaz de Ihes interessar, de 'prender sua atenção', isto é, de entrar em suas categorias, em sua grade, e ao relegar à insignificância ou à indiferença expressões simbólicas que mereceriam atingir o conjunto dos cidadãos". ${ }^{136}$

É essa censura que sofre a América Latina.

Bourdieu, ao afirmar que ações ou discursos merecem atingir o conjunto dos cidadãos, está colocando uma visão do que ele considera um jornalismo ideal. Ele afirma que a televisão (ou qualquer outro veículo da grande imprensa) está "perfeitamente ajustada às estruturas mentais do público". Aqui, é preciso explicar a que público se refere. Diferentemente do conceito de jornalismo integral em que o termo "público" compreende todo o conjunto da sociedade, as indústrias de comunicação definem e separam para qual público produzem seus veículos: apenas para aqueles que podem ser consumidores (não só do veículo em si, mas principalmente dos produtos anunciados).

Ora, na óptica da grande imprensa é perfeitamente natural adotar como óculos os mesmos da faixa da sociedade a que são destinados: as elites dos países latinoamericanos. Como foi visto nos capítulos I e II, essas elites são preconceituosas, herdeiras dos padrões e consensos dos colonizadores, sempre estiveram associadas ao estrangeiro (principalmente ao capital externo) e sempre reprimiram todas as tentativas das massas de se organizar e protestar. A retrógrada e conservadora elite latino-americana é a proprietária dos veículos de comunicação da grande imprensa e é o verdadeiro público dos seus jornais. Portanto, não há incoerência entre o discurso visto no noticiário latino-americano que suprime o popular e o relega à condição de inferioridade, porque essa é, historicamente, a

\footnotetext{
${ }^{136}$ BOURDIEU, Pierre. Sobre a Televisão. Seguido de A influência do jornalismo e Os Jogos Olímpicos. Tradução de Maria Lúcia Machado. Rio de Janeiro: Jorge Zahar Editor, 1997. p 67.
} 
lógica da elite latino-americana. O que existe, de fato, é a miopia de acreditar que a grande imprensa fala para todo o público latino-americano em sua integralidade.

Quando Néstor García Canclini diz que há uma exigência do receptor em ler notícias ligadas ao eixo EUA-Europa, deveria salientar que o receptor, no caso, é um integrante da elite conservadora latino-americana e não o camponês, o operário, a classe subalterna. contrato descrito por Canclini, na verdade, é o mesmo contrato já assinado há mais de 500 anos na América Latina: as classes populares não merecem oportunidade nessa terra. As classes populares não podem ter espaço nas ruas, não podem se organizar, não podem formar partidos políticos, não podem ganhar debates nos congressos, não podem ter voz nos meios de comunicação.

Mesmo que as classes populares queiram formar seus próprios meios de comunicação para ter espaço e voz, as lógicas do mercado editorial não permitirão que esses meios alternativos sobrevivam, como se verá adiante. A miopia dos estudiosos de Comunicação, que não enxergam esta lógica, pode ser explicada, em parte, pelo discurso da grande imprensa, que não admite publicamente essa postura de repressão e de segregação de público, como será explicado no próximo tópico.

A grande imprensa cria um discurso fantasioso para explicar as razões que a levam a selecionar notícias. Se de um lado os jornalistas se pautam em outros e a disputa pelo índice de audiência provoca o canibalismo dentro do campo jornalístico, por outro, devolvem a responsabilidade desse sistema para um ser abstrato, chamado "público". Quando um jornalista diz que determinado assunto "não interessa ao público", ele está afirmando que o "público" "aceita" as categorias escolhidas como sendo também as suas. Entretanto, como foi visto, essa premissa não é verdadeira. O jornalista escreve não para um público, mas para um consumidor. Ou seja, o jornalismo da grande imprensa é feito exclusivamente para a América Latina Oficial, mas seu discurso é de que o noticiário é escrito para toda a América Latina. 


\section{1 Óculos formatados no eixo EUA-Europa}

O tom do discurso de Gabriel García Márquez ao receber o Prêmio Nobel de Literatura, em 1982, era de que a América Latina, finalmente, existia para a Europa. Os fatos que se sucederam nos anos 60 e 70, na opinião do escritor colombiano, tinham levado o mundo a olhar para o continente. O que entristecia García Márquez é que a Europa tinha prestado atenção a esses fatos, mas a própria América Latina tentava jogá-los para debaixo do tapete, o que ficou claro durante os anos 80 e 90, quando o continente embarcou na onda neoliberal e aumentou ainda mais a exclusão.

A América Latina, incluindo o Caribe, tem seis prêmios Nobel de Literatura e dois de Paz, entre outros reconhecimentos internacionais. Um país da América Central, a Guatemala, pequeno na extensão, tem um Prêmio Nobel de Literatura, Miguel Angel Astúrias, autor de Weekend na Guatemala e outro de Paz, ganho por Rigoberta Menchú. Mesmo com essa "chancela" do exterior, um programa do Globo Repórter transmitido em 2004 sobre a Guatemala ainda se focava no exótico: a pajelança indígena, os mistérios das pirâmides, as roupas coloridas dos índios. O repórter brasileiro passeando pelo mercado parecia um arqueólogo europeu descobrindo uma nova civilização. Nenhuma palavra sobre um dos fatos mais marcantes da história contemporânea guatemalteca: o golpe de Castillo Armas, patrocinado econômica e militarmente pela CIA que derrubou o governo progressista de Jacobo Arbénz. Episódio que influenciou Che Guevara a defender a guerrilha e as milícias como forma de combater o imperialismo norte-americano.

Esse é um exemplo dentre milhares e não é exclusivo da América Latina. As matérias especiais sobre a África têm o mesmo tom das cartas dos navegadores portugueses ao chegar no novo mundo. A imagem de mulheres nuas e dos rituais festivos africanos nos televisores, aos domingos, é semelhante às exposição dos indígenas nas cortes do Velho Mundo. Também não é exclusividade do noticiário internacional. Qualquer matéria sobre os subúrbios, as periferias ou as pequenas cidades do interior do Brasil transmite a mesma sensação de olhar estrangeiro. No caso brasileiro, a imprensa centrada 
no eixo Rio-São Paulo considera exótico a existência de casas de pau-a-pique e telhado de sapê ou os sabores das diferentes culinárias regionais. O sotaque nordestino é suprimido até dos repórteres locais. Há um distanciamento da imprensa em se sentir brasileira na integralidade, e esse distanciamento é ainda maior no tocante à América Latina.

"Pela primeira vez na história, a maioria dos bens e mensagens que se recebem em cada nação não são produzidos em seu próprio território [...] procedem de um sistema transnacional, desterritorializado de produção e difusão". ${ }^{137}$ Os meios de comunicação adotam categorias norte-americanas de seleção e tratamento dos fatos regionais. A começar pelo próprio uso do lead e do conceito de objetividade, importados do jornalismo norte-americano.

Na mesma época em que a editora universitária Unesp lançava um livro sobre a revolução guatemalteca, explicando os detalhes da derrubada de Arbénz como síntese do processo em dominó de implantação de ditaduras para deter o avanço latino-americano do comunismo, três grandes revistas semanais brasileiras deram suas capas para o brasileiro Paulo Coelho que lançava mais um título (O Zahir) simultaneamente em 80 países. Paulo Coelho é brasileiro, mas ganhou a chancela do exterior. Vende muito, gera lucros, é bom para o mercado. Por isso foi responsável pelas três capas - fato inédito quando não se trata de desastres, tragédias naturais ou acontecimentos espetaculares. É mais do que uma pauta consensual, é pensamento único. A notícia do lançamento do livro sobre a revolução guatemalteca circulou apenas em e-mails mandados pela assessoria de imprensa da Unesp.

Desmonta-se o mito de que não há espaço suficiente. O que não há é interesse. São os meios de comunicação que constroem o que existe o que não existe, como mostra o texto de Guareschi:

"Não seria exagero dizer que a comunicação constrói a realidade. Num mundo todo permeado de comunicação - um mundo de sinais - num mundo todo teleinformatizado, a única realidade passa a ser a representação da realidade - um mundo simbólico, imaterial. Isso é tão verdade, que na linguagem do dia-a-dia já se podem ouvir frases como estas: 'Já

${ }^{137}$ CANCLINI, Néstor García. De Cartagena a Miami: Políticas Multiculturales e Integración por el Mercado apud FERREIRA, Maria Nazareth. Globalização e Identidade Cultural na América Latina. São Paulo: CEBELA, 1995. 
acabou a greve?. [...] 'Deve ter acabado, pois o jornal não diz mais nada' ou 'A televisão não mostrou mais nada'. A conclusão a que chegamos é a de que uma coisa existe, ou deixa de existir, à medida em que é comunicada, veiculada. É por isso, conseqüentemente, que a comunicação é duplamente poderosa: tanto porque pode criar realidades, como porque pode deixar que existam pelo fato de serem silenciadas." ${ }^{138}$

"A América Latina é uma região que guarda uma riqueza cultural valiosa, tanto do ponto de vista estético, como também do patrimônio histórico e social." ${ }^{139} \mathrm{E}$ toda esta riqueza não existe para a população da América Latina oficial porque os meios de comunicação ligados a essa parcela do continente não a veiculam. Pelo contrário, boa parte do noticiário - em qualquer editoria - dá preferência ao estrangeiro.

O movimento atinge os diversos veículos e é herdeiro do processo de americanização visto no Capítulo II, quando os programas de rádio e as revistas de maior sucesso na América Latina eram produzidos nos Estados Unidos. Os jornais diários sentemse felizes por produzir (traduzir, na verdade) cadernos do Wall Street Journal ou por estabelecerem acordos com o New York Times. Na TV, o fenômeno é ainda maior. Além da importação de seriados, os programas de entrevista seguem o mesmo formato dos talkshows norte-americanos (o Programa do Jô da Rede Globo mimetiza de Larry King desde a roupa no estilo suspensórios/gravatas escandalosas até a cenografia) e a nova febre dos reality shows trata-se da compra das franquias de formatos de sucesso na Europa ou nos EUA.

Esse trabalho não pretende se aprofundar no processo de fetichização e voyeurismo dos programas no estilo do Big Brother (cujo nome é de péssimo gosto). Para o objetivo da dissertação é importante ressaltar que a adoção de modelos estrangeiros como carros-chefe dos meios de comunicação latino-americanos apenas acelera o processo de distanciamento do regional e de aproximação com o externo.

A apropriação da cultura das classes subalternas pela mídia das classes dominantes faz parte do processo de manipulação para modificar as manifestações populares em símbolo nacional. A cada época, a mídia seleciona um aspecto da cultura popular para

${ }^{138}$ GUARESCHI, Pedrinho A. (org). Comunicação e controle social. Petrópolis: Vozes, 1991.

${ }^{139}$ FERREIRA, Maria Nazareth. Globalização e Identidade Cultural na América Latina. Op. Cit. p. 25. 
elegê-lo como símbolo do Brasil. Este processo é facilitado quando, por alguma razão, essa manifestação ganha chancela no exterior. É o caso quando algum cantor, grupo de teatro ou uma produção cinematográfica ganha prêmios no circuito internacional.

Quando a manifestação não recebe a chancela do estrangeiro, a indústria cultural a transforma em produto. Foi o que aconteceu com a música sertaneja, com o samba de roda e com o forró, no caso brasileiro. Cada um, em uma fase que pode durar menos de um ano, foi eleito como símbolo cultural brasileiro, numa cadeia de reprodução que vai da indústria fonográfica ao mercado editorial, passando pelas telenovelas e pelos programas de TV. Passada a fase de consumo, as manifestações são esquecidas e são relegadas à categoria do kitsch.

Este processo de subordinação ao estrangeiro segue a mesma linha descrita por Francisco de Oliveira em O Ornitorrinco. Toda a América Latina está presa numa situação esdrúxula, em que ainda não alcançou o estágio de desenvolvimento suficiente para se enquadrar no estágio da Terceira Revolução Industrial (ou molecular-digital) e sofre para que algumas regiões cheguem à Segunda Revolução Industrial. As burguesias nacionais de cada nação latino-americana abdicaram da tarefa de desenvolvimento autônomo e preferiram a aliança com o capital estrangeiro. Por isso, as indústrias com mais tecnologia na América Latina são européias ou norte-americanas. Apenas utilizam a mão-de-obra local. Da mesma forma, os meios de comunicação abdicam das iniciativas de desenvolvimento de produções locais e adotam os modelos estrangeiros. Também os meios de comunicação latino-americanos são ornitorrincos.

Outro ponto importante é que as elites latino-americanas não têm interesse na participação efetiva das classes subalternas no desenvolvimento dos meios de comunicação. Há um boicote - às vezes velado, às vezes explícito - contra qualquer tentativa de manifestação popular pelos meios de comunicação.

"Existe uma política de desvalorização e desmobilização de recursos comunicacionais das classes subalternas (experiências de rádio e de televisão comunitárias, 
de práticas políticas participativas) que têm de subsistir na ilegalidade." ${ }^{140}$ Como se verá a seguir, toda as alternativas de imprensa de resistência na América Latina foram desestabilizadas, seja pela repressão ou pelo fracasso econômico como se verá a seguir.

${ }^{140}$ FERREIRA, Maria Nazareth. Op. Cit. p. 28. 


\subsubsection{As mídias alternativas}

Não há trabalho jornalístico que não seja ideológico. Porém, não há apenas aparelhos ideológicos conservadores. $\mathrm{Na}$ análise marxista, as idéias da classe dominante são as idéias dominantes, e, como há sempre uma classe em luta contra a dominante, existem as idéias de luta, de oposição.

Já existiram diversos veículos progressistas como os jornais Movimento, Opinião,

\section{Em Tempo, O Companheiro, O Trabalho, O Repórter de Guarulhos, O Repórter de} Campinas, O Repórter da Baixada, O Espalha Fato, O Jornal da Vila, O Jornal da Periferia, que chegaram a ter circulação média e penetração nas massas, além da imprensa sindical e ligada a partidos políticos.

Essa imprensa, para Bernardo Kucinsky, tinha quatro características essenciais: "não estava ligada a políticas dominantes; era uma opção entre duas coisas reciprocamente excludentes; a única saída para uma situação difícil e era o desejo das gerações dos anos 60 e 70 de protagonizar as transformações sociais que pregavam". ${ }^{141}$

Para Maria Nazareth Ferreira, a história da imprensa proletária é a história de uma importante manifestação da luta entre a classe trabalhadora e as classes detentoras dos meios de produção. Na América Latina, a imprensa das classes subalternas (chamada às vezes de alternativa, operária ou proletária) sofre com o dilema de pertencer à esfera das classes subalternas, de ter a tarefa de documentar a história destes setores e livrá-los de serem excluídos da história pela historiografia oficial e, ao mesmo tempo, ter de se sujeitar às regras do jornalismo empresarial e obter financiamento para seus veículos.

Mesmo sendo meios de comunicação alternativos, não conseguem se sustentar sem algum meio de financiamento: anúncios, assinaturas ou venda em banca. A diferença entre os dois processos de venda é que os veículos da grande imprensa vendem notícias quando poderiam vender carne, carros ou qualquer outro produto, a grande imprensa capitalista é uma indústria como outra qualquer. O lucro é obtido por meio dos anúncios de outras ${ }_{141}$ KUCINSKY, Bernardo. Jornalistas e Revolucionários. São Paulo: Scritta, 1991. Apresentação. P. XIII. 
empresas veiculados nos jornais, revistas e demais programas. A simples venda de jornais e assinaturas não garante o lucro desejado. Portanto, as indústrias jornalísticas precisam convencer os demais setores da economia que: a) têm grande circulação; b) têm grande número de leitores e c) os leitores estão dentro do público alvo das empresas.

Um fabricante de roupas femininas quer anunciar seu produto em veículos que atinjam o maior número de leitoras em idade e condições financeiras de adquiri-lo. De nada adianta anunciar em uma revista infantil ou exclusiva do público masculino. É uma análise simplificada dos estudos de mídia da área de Publicidade e Propaganda. Os conceitos de TARP, GRP, alcance, share, freqüência, entre outros são complexos - envolvem teorias que vão da psicologia à economia - e tentam reduzir ao mínimo o desperdício do dinheiro dos anunciantes. Entretanto, uma regra é clara: por mais específico que seja o produto ou serviço a ser anunciado, é bem mais confiável ao anunciante investir em um veículo que alcance o maior número de pessoas possível. Se esse número de pessoas está dentro do público alvo, tanto melhor. Essa combinação é que torna alguns anúncios muito mais caros.

É com esta lógica que sobrevivem os veículos da grande imprensa. Quando Bourdieu critica os meios de comunicação por serem carregados de assuntos ônibus e por não trazerem, de maneira explícita, a ideologia e partidarismo da classe a que são ligados, mostra a fórmula encontrada pela grande imprensa para conseguir mais público e garantir mais verbas publicitárias: o discurso de que são veículos indispensáveis, destinados e dirigidos à TODA população (não ler a Folha, não ouvir a Bandeirantes, não assistir ao Jornal Nacional e não ler a Veja torna-se sinônimo de isolamento e despreparo). Na verdade, é sabido que os veículos da grande imprensa são feitos pela elite da nação burguesa para a elite da nação burguesa. ${ }^{142}$

Uma das campanhas publicitárias veiculadas pelo jornal O Estado de S. Paulo mostrava, em uma série de filmes, como a falta de conteúdo nas conversas provocava situações constrangedoras. Ficou famosa a expressão "cara de conteúdo" para designar alguém que não tinha o que falar (pois não lera nada) e ficava apenas observando os

\footnotetext{
${ }_{142}$ Sobre a relação entre assuntos ônibus e anunciantes ver o tópico Informação e opinião.
} 
acontecimentos. Com a campanha, o jornal provava que era a solução para a falta de conteúdo informacional, ou seja, leia o Estadão ou perca a chance de ser promovido no trabalho, seja excluído das conversas com os amigos, fique desatualizado para estudar com seu filho, não tenha diálogo com sua esposa ou fique sozinho na mesa do bar.

Assim, por mais que o $\mathbf{O}$ Estado de $\mathbf{S}$. Paulo reflita apenas o que a oligarquia paulista pensa e defenda sobre o Brasil e o mundo, qualquer um que não queira se ver nas situações citadas vai comprar e ler o jornal, mesmo que não pertença à oligarquia. Ganham com isso o jornal que amplia seus argumentos para os anunciantes e estes, pois além de terem a oportunidade de colocar seus produtos e serviços em vitrines maiores, podem ampliar ideologicamente os sonhos de consumo, mesmo entre a população que não tem poder aquisitivo.

O valor de um produto é dado não só pelo seu custo real (matéria prima, mão-deobra, publicidade, logística, margem de lucro), mas também por seu valor simbólico. Objetos de desejo como canetas Mont Blanc, roupas Armani, bolsas Louis Vitton, restaurantes como Fasano e Don Curro não estão ao alcance de todos os leitores do Estadão, isto é claro para os anunciantes. Contudo, o fascínio e o sonho de consumo que despertam no imaginário da população aumentam seus valores simbólicos e justificam - em certa medida - os preços exorbitantes. 
Portanto, mais do que venda de notícias, o que a grande imprensa vende é seu espaço para anúncio. A Folha de S.Paulo não se incomoda de estampar apenas a manchete na primeira página do caderno "Mundo", deixando o restante do espaço para anúncios e colocando a matéria na página seguinte. A diagramação de qualquer jornal começa a ser feita pelos anúncios, o noticiário preenche o resto. Os programas televisivos têm anunciantes fixos ou específicos para cada modalidade. A cobertura de acontecimentos, como a Copa do Mundo, é financiada pela venda antecipada de cotas publicitárias.

Esse mecanismo tão bem azeitado na grande imprensa é deficiente na mídia alternativa ou das classes subalternas. Os veículos se mantêm pela assinatura, venda direta ao leitor ou permuta com outras publicações. No caso da imprensa alternativa brasileira, a revista Caros Amigos e o Jornal Brasil de Fato, por exemplo, fazem inserções recíprocas. Fora destas permutas há anúncios de prefeituras ou governos ligados a partidos de esquerda.

A imprensa alternativa alega que busca a independência dos anunciantes. Contudo, falta um trabalho de convencimento, por esses veículos, junto a anunciantes em potencial. Convencer empresas de que a publicação mantém uma produção jornalística de qualidade e que por isso consegue um público restrito, mas seleto, seria uma forma de atração. Como foi dito, não é só de grande número de leitores que é feita a seleção de mídia para anúncios. Para determinados produtos ou serviços também é importante comunicar-se diretamente com o público-alvo desejado. 
A pesquisa feita pela empresa Somatório Pesquisas de Marketing Ltda (2004) a pedido da revista Caros Amigos ${ }^{143}$ mostra que os leitores desta revista são em sua maioria $(65,3 \%)$ do sexo masculino, têm entre 20 e 39 anos (59,4\%), têm acesso à Internet $(75,2 \%)$, cursam nível superior $(38,2 \%)$ ou já tem nível universitário $(33,7 \%)$ ou pós-graduação $(18,9 \%)$ e pertencem às classes B1 e B2 $(48,3 \%)$. Apresentam como hábitos de lazer a leitura $(83 \%)$, a música $(68 \%)$ e o cinema $(40 \%)$. Esses dados, se bem apresentados e contextualizados, convenceriam empresas como editoras, gravadoras, distribuidoras de filmes, entre outras. Se há preconceito dos anunciantes - ou receio de matérias que firam interesses destas empresas -, esse é um estudo que ainda demanda melhor tratamento.

No entanto, por mais independente que seja a relação entre anunciantes e imprensa alternativa, o fato de manter a mesma lógica de financiamento que a grande imprensa implica numa luta desigual entre ambas, que tende a ser vencida pela grande imprensa. José Arbex Jr, diretor do jornal Brasil de Fato, usa a expressão "guerra de guerrilhas" para designar essa luta entre os dois tipos de imprensa. É uma guerra que se estabeleceria na qualidade das notícias, na originalidade da pauta, na disputa de leitores nas bancas e, seguindo a lógica dos anúncios, na disputa por empresas que financiassem este tipo de comunicação.

Disputar leitores e vencer a guerra pela qualidade e originalidade do noticiário é tarefa típica da guerrilha. Toda guerrilha caracteriza-se pelo enfrentamento de um pequeno grupo fortemente conscientizado com um exército - ou outra instituição - regular de poderio militar muito maior. Os manuais de guerrilha de Ho Chi Min a Che Guevara preconizam que o grupo guerrilheiro só pode vencer o exército regular se a batalha for estabelecida num campo em que a guerrilha atue com mais liberdade e no qual o exército regular tem dificuldade.

\footnotetext{
${ }_{143}$ Disponível no site da Revista Caros Amigos. www.carosamigos.com.br. Acesso em 01 mai 05.
} 
Os vietcongs e os revolucionários de Sierra Maestra venceram a batalha militar entre outros fatores - por aplicarem estratégias como combates noturnos, armadilhas, emboscadas, ataques rápidos e recuos estratégicos. A grande máquina militar norteamericana com porta-aviões, tanques e bombardeiros de nada adiantou contra escaramuças no meio da selva, túneis subterrâneos que cortavam todo o país e canhões antiaéreos escondidos no meio do arrozal. Outro ponto fundamental da guerrilha é o apoio da população - que abriga guerrilheiros e serve de ponto de abastecimento e esconderijo para armamentos.

Nessa analogia, a imprensa alternativa poderia estabelecer uma guerra de guerrilhas com a grande imprensa num campo de batalha em que esta não se sente à vontade, ou seja, na seleção de notícias que escapem aos assuntos ônibus e que, clara e explicitamente, mostrem qual partido defendem. Enquanto a grande imprensa tenta atingir o maior número de receptores possível, maquilando o noticiário de maneira que ele pareça plural e recheando de assuntos que não choquem por não têm conteúdo político, a imprensa alternativa deve buscar o contrário: rechear seu noticiário de temas polêmicos, adotando abertamente posturas em relação aos fatos que podem interferir no dia-a-dia das sociedades.

Levar a disputa para o campo dos anúncios e da circulação é estabelecer a batalha com exército regular em campo aberto. É o guerrilheiro de AK-47 atirando contra tanques blindados. A grande imprensa se especializou - e se especializa a cada dia - na arte de ganhar cada vez mais anunciantes, reforçando a ordem capitalista. Quanto mais desigual é a sociedade, mas criativos são os anúncios, maior é a capacidade das agências de publicidade de atrair novos consumidores. Para perpetuar essa máquina é que existem cursos superiores de Publicidade, Propaganda e Marketing. Se a imprensa alternativa entrar na disputa por publicidade não só está fadada a perder como só fará perpetuar o capital, perdendo o princípio de defender, por meio do seu noticiário, a visão de mundo que defende. 
Outro caminho que não o da veiculação de anúncios seria o financiamento por um grupo político ou movimento social que tenha a comunicação como forma de militância. É o caso do MST, que, no Brasil, é a melhor manifestação de imprensa alternativa. O MST, de fato, promove uma guerra de guerrilha contra a grande imprensa. No depoimento de um integrante do movimento:

"O MST entende que a Comunicação é um direito universal, é um patrimônio da humanidade e, como tal, deve ser utilizada. Como a gente luta pela terra, a gente luta pela comunicação, porque a relação do monopólio da terra e do monopólio da comunicação são grandes impedimentos da consolidação da democracia neste continente Da mesma forma que a terra é um patrimônio da humanidade e tem uma função social, as relações de comunicação devem estar a serviço da maioria da população e devem atender à grande diversidade cultural, histórica e à grande diversidade de relações." ${ }^{144}$

Ciro Marcondes entende que essa forma de jornalismo - chamado por ele de comunitário - não pode seguir a mesma lógica do Jornalismo de grande imprensa.

Fazer jornal comunitário não é buscar grupos étnicos, religiosos, culturais, nacionais, geográficos, com mensagens para "aquele público", como exploração de fatias de mercado. Tal procedimento é o mesmo do jornal não-comunitário. [...] Um jornal comunitário, diferente disto, é elaborado por membros de uma comunidade que procuram através dele obter mais força política, melhor poder de barganha, mais impacto social, não para alguns interesses particularizados (anunciantes, figuras proeminentes), mas para toda a comunidade que esteja operando o veículo. [...] Enfim, qualquer comunidade pode articular-se politicamente e, a[i, utilizar-se de um jornal comunitário onde sua voz ganhe mais eco, suas reivindicações cheguem muito mais além do que seu território". ${ }^{145}$

Por esses motivos, o MST mantém três veículos de comunicação periódicos diferentes (o Jornal Sem Terra, a Revista Sem Terra e a Rádio Vozes da Terra), além de diversas outras formas, como boletins, cartilhas, exposições, festivais de cinema e de teatro. A $1^{\text {a }}$ Oficina de Linguagem Audiovisual, promovida pelo movimento em 2000 no assentamento Dorcelina Folador, resultou em produções de documentários que servem de voz na contra mão da grande imprensa. Logo depois da publicação de "A tática da baderna" pela revista Veja, o MST divulgou Uma luta de todos: o MST pelo MST que conta a história do movimento, suas principais bandeiras, a produção agrícola e o uso de tecnologias alternativas nos assentamentos. O vídeo também serviu de material para a

${ }^{144}$ CORTEZ, Garcia. O MST e seus sistemas de comunicação. In: FERREIRA, Maria Nazareth.

Cultura, Comunicação e Movimentos Sociais. CELACC - ECA/USP, 1999.

${ }^{145}$ MARCONDES FILHO, Ciro. Quem manipula quem?: poder e massas na indústria da cultura e da comunicação no Brasil. Petrópolis: Vozes, 1986. p 160-62 
produção do documentário Raiz Forte, realizado pelo Centro de Justiça Global, com produção roteiro e direção de Aline Sasahara e Maria Luisa Mendonça.

Ler a matéria "A tática da baderna" ${ }^{146}$ e assistir a Uma luta de todos... ${ }^{147}$ é assistir a uma guerra de guerrilhas. De um lado, o grupo Abril e todo seu gigantesco poderio econômico, dezenas de anunciantes, empresas de distribuição que garantem a circulação por todo o país, produz uma matéria que até utiliza como gancho a morte do sem-terra Antonio Pereira; do outro lado está o MST, principal movimento social latino-americano desde a derrota das organizações de esquerda armada nos anos 60 . O vídeo é aberto citando a morte de Antonio Pereira.

\footnotetext{
${ }^{146}$ SHELP, Diogo. O Clone do Totalitarismo. In: Veja. Edição 1903 - ano 38 - n 18. São Paulo: Editora Abril, 4 de maio de 2005. p. 156.

${ }^{147}$ Uma Luta de Todos. Oficina de Linguagem Audiovisual FILO/MST. Criação e produção coletiva. 27 min. VHS. NTSC. Maio de 2000.
} 
Enquanto na matéria de Veja, as cenas do episódio que resultou na morte do agricultor são retratadas em fotos que justificariam a "baderna" estabelecida pelo MST, no vídeo as mesmas cenas mostram toda a truculência da polícia paranaense. A matéria de Veja traz a foto do policial militar em meio aos sem-terra deitados, com as mãos nas costas em oposição com a foto do soldado norte-americano paramentado para "enfrentar multidões". A oposição das fotos mostra o policial brasileiro como vítima. Ele empunha "apenas" um revólver e um colete a prova de balas e usa uma boina, enquanto que o norteamericano está preparado para a guerra.

No vídeo do MST a polícia militar nada tem de vítima. Ao som de "Pai Nosso dos Mártires", canção das comunidades eclesiáticas de base, influência da Teologia da Libertação, as cenas impressionam. São viaturas jogadas para cima dos trabalhadores, policiais disparando bombas de gás, atirando e caminhando furiosamente contra os semterra que correm para o mato. O vídeo mostra os ferimentos nos trabalhadores: corpos sangrando pelos estilhaços ou pelas balas de borracha, cães babando em cima de homens deitados, um policial, de revólver em punho chama os trabalhadores de covarde, outro chuta as costas de um agricultor que anda com as mãos na cabeça. Helicópteros sobrevoam o local.

A matéria de Veja é mais uma em uma edição semanal de uma revista feita pela elite, para a elite, financiada pela elite. Cumpre seu papel de ser a voz dos vencedores, de manter o estado das coisas. O Grupo Abril não é a favor da união dos trabalhadores da cidade e do campo, muito menos do Socialismo. O texto e as imagens apenas reforçam o que o grupo e seu financiadores pensam e defendem para o mundo. Na semana seguinte, a capa poderia ser sobre vida após a morte, a separação de algum casal famoso, a estréia de alguma superprodução cinematográfica ou qualquer outro assunto ônibus.

A lógica de um veículo de grande imprensa segue seu ritmo. O MST não pode seguir o mesmo padrão. O vídeo produzido numa oficina deve conscientizar os militantes, alertálos sobre a campanha empreendida pela grande imprensa. O vídeo é a versão do MST sobre os fatos. É preciso ter carga emocional - daí a utilização de "Pai Nosso dos Mártires", 
como trilha sonora. Depois das cenas de brutalidade, um documentário que mostra o sucesso do Assentamento Dorcelina Folador: a história e origens do MST, o processo de ocupação de terras devolutas, o trabalho na terra, o uso da agricultura orgânica, entrevistas com moradores da cidade vizinha ao assentamento confirmando apoio ao movimento, as escolas do assentamento, a educação de crianças, jovens e adultos. Nos créditos do vídeo, os nomes das equipes que produziram o documentário: Equipe Sebastião Salgado, Equipe Sandino, Equipe Gaudino, Equipe Emiliano Zapata. No final do vídeo, o agradecimento a Che Guevara, como exemplo e fonte de inspiração.

Há quem critique o excesso de politização do vídeo. A produção do MST é carregada de influências políticas revolucionárias, sobretudo latino-americanas. A crítica é vazia. Primeiro, porque Veja também faz esse papel, porém, disfarçada de veículo plural. Segundo porque é justamente este o papel da mídia alternativa: marcar posição, enfatizar as influências, ser a voz do projeto de mundo que o grupo deseja, ser a opção em uma situação de exclusão. Diante da calúnia feita pela revista Veja, o vídeo é a versão do MST. E mais um diferencial: a América Latina está presente no vídeo do MST, na referência a Sandino, Gaudino, Zapata e Guevara, e está ausente na matéria de Veja.

A cultura das classes subalternas é a principal forjadora da identidade cultural latinoamericana. "Na América Latina, a construção da identidade cultural é parte integrante das lutas por igualdade social, uma não pode ser resolvida sem a outra". ${ }^{148}$

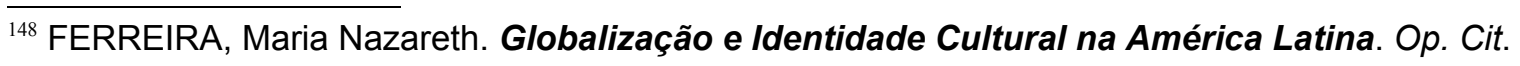


Seja por meio da luta com os veículos da grande imprensa nas bancas de jornais, como batalham a Caros Amigos e o Brasil de Fato, seja buscando meios alternativos para se manifestar, como faz o MST, a imprensa alternativa é a grande voz da América Latina. É apenas nesses veículos que o continente ganha importância, é retratado em toda sua complexidade e riqueza. Fora do esquema da pauta consensual, livre dos preconceitos enraizados pela herança histórica, próxima ao dia-a-dia das lutas de resistência na América Latina, a imprensa alternativa cumpre seu papel. A mídia alternativa é a única que se dedica aos vencidos da história.

"Como um dos poucos depositários das experiências e vivências das classes subalternas, cabe à imprensa proletária importante tarefa de documentar a história destes setores da sociedade [no caso da América Latina popular]. As páginas desta imprensa narram a história das derrotas populares, das rebeliões vencidas e dos heróis anônimos sacrificados em nome da coletividade. Nos seus registros [...] é possível a recuperação destas memórias perdidas, propositalmente apagadas, mas autênticas e ricas em ensinamentos, lições a serem aprendidas. A história recente do Brasil está repleta destes acontecimentos; apagá-los, como faz a historiografia oficial, significa desarmar as classes subalternas de suas realizações históricas, de sua memória, de sua cotidiana resistência." ${ }^{149}$

Se a grande imprensa representa interesses da classe que a financia (as elites da América Latina burguesa) e para isso utilizam grande volume de recursos financeiros e tecnologia avançada, a imprensa das classes subalternas deve procurar métodos alternativos para difundir suas idéias, educar politicamente e ser organizadora da luta destas classes. Como faz o MST. Para Ciro Marcondes:

Essa é a proposta para um jornalismo comunitário, que não esteja apenas preocupado com a abordagem mercadológica dos problemas de seu leitor, mas também empenhado em organizar movimentos sociais e unificar esforços individuais em defesa de interesses comuns, normalmente menosprezados na sociedade, mas que representam grandes massas urbanas [e rurais]. É a forma de o indivíduo poder afirmar-se e fazer valer sua posição sem ser deglutido pelas máquinas de informação oficiais, públicas ou privadas, que tudo fazem, menos solucionar os problemas e as necessidades da população. ${ }^{150}$

É o que defende esta dissertação.

\footnotetext{
${ }^{149}$ FERREIRA, Maria Nazareth. Comunicação e resistência na imprensa proletária. Tese de Livre Docência. ECA/USP, 1990, p. 6.

${ }^{150}$ MARCONDES FILHO, Ciro. Quem manipula quem?: poder e massas na indústria da cultura e da comunicação no Brasil. Petrópolis: Vozes, 1986.
} 
Infelizmente, nas últimas décadas do século $X X$, a imprensa alternativa não conseguiu se distanciar do modelo de dominação das classes hegemônicas, seja pela insistência em disputar o mesmo tipo de anúncio com a grande imprensa, seja pela própria ineficiência dos partidos proletários e sindicatos. Nas primeiras décadas desse século a imprensa alternativa era atrelada a ligas, sindicatos e uniões de trabalhadores. A partir da fundação do PCB, passa a ter forte influência do partido. Ela sofreu com as várias fases do PCB até 1964, quando a resistência o golpe militar trouxe um novo tipo de imprensa, muito próxima dos pasquins publicados no primeiro império. Com o fim da ditadura e também com a crise do horizonte histórico do socialismo real e a influência do neoliberalismo na América Latina, muitos sindicatos perderam a capacidade política.

Os sindicatos, nos últimos anos do século $\mathrm{XX}$ e início do $\mathrm{XXI}$, deslocaram o discurso para a luta econômica, quando havia discurso. As comemorações do Dia do Trabalho no Brasil tornaram-se disputas midiáticas entre a CUT e a Força Sindical que se esforçam para levar o maior número de pessoas aos seus shows, esvaziados de política e sobrecarregados de mídia: o público vai ao show para concorrer no sorteio de apartamentos e carros e ver artistas televisivos que cantam no palanque dos sindicatos da mesma forma que poderiam cantar em festas de grandes corporações de mídia ou em comícios de políticos de direita.

Essa deficiência política dos partidos e sindicatos na América Latina leva a um quadro não muito otimista da atual imprensa alternativa. À exceção do sistema de comunicação do MST - que, como foi mostrado acima, está definitivamente numa guerra de guerrilhas -, todos os outros veículos, apesar de brilhantes esforços, lutam dia após dia para permanecerem vivos.

Esse é o panorama dos mais significativos veículos da mídia alternativa que dão espaço para a América Latina popular:

BRASIL DE FATO - O jornal Brasil de Fato nasceu durante o III Fórum Social Mundial, realizado em Porto Alegre. Semanal, no formato standard, tem objetivo semelhante 
a seus irmãos da mídia alternativa: retratar em suas páginas o que a grande imprensa não noticia. Influenciado pelo slogan do Fórum Social, "um outro mundo é possível", o Brasil de Fato acredita que outra mídia é possível. Nos conselhos político e editorial da publicação há vários intelectuais e militantes de organizações de esquerda. Apesar de contar com vários colaboradores ligados ao MST, não é o órgão oficial do movimento, que já conta com veículos próprios.

Um dos diferenciais do Brasil de Fato em relação aos demais veículos da mídia alternativa é contar com colaboradores em vários estados do Brasil, o que resulta numa cobertura mais ampla do país. Neste ponto, contrapõe-se à grande imprensa que se limita ao eixo Rio-São Paulo. Outra característica importante do Brasil de Fato é ter uma página exclusiva para a América Latina e outra para a África. Considerando-se que se trata de uma publicação de 16 páginas, isso é de grande significância para essas regiões do mundo. Também há uma seção exclusiva para a agenda de divulgação dos movimentos sociais. As demais páginas, além de abrigar colunas, são dedicadas ao noticiário brasileiro. Para manter esse ritmo, o Brasil de Fato conta com uma grande equipe de colaboradores, alguns não remunerados, que enviam material ao jornal por objetivos ideológicos.

Como os demais veículos, a publicação sofre com a concorrência com a grande imprensa, especificamente na distribuição, o que frustrou o sonho de ser um veículo nacional que efetivamente se "chocasse" com Folha de S.Paulo e O Estado de S. Paulo. Não há um movimento social que o mantenha - o jornal sobrevive por meio de assinaturas, permutas com outras publicações e anúncios de prefeituras municipais comandadas por partidos de esquerda. No entanto, esta verba publicitária não é suficiente para manter uma estrutura nacional de distribuição e circulação.

Com a vitória do PT nas eleições de 2002 o jornal comemorou a eleição de um presidente de esquerda. Porém, com a aproximação do governo brasileiro à ala de centrodireita, o jornal não conseguiu estabelecer uma crítica distante o suficiente para não afastar militantes do PT e, ao mesmo tempo, mostrar independência em relação à política econômica de caráter neoliberal. Ainda assim, é uma das poucas publicações semanais da 
mídia alternativa impressa, de caráter nacional, que mantém qualidade técnica e editorial. $\mathrm{O}$ jornal não tem o aspecto de um "panfleto" partidário.

AMÉRICA LIBRE - Dirigida pelo intelectual brasileiro Emir Sader, depois da saída de Frei Betto para o governo Lula. Esse distanciamento de um governo de esquerda é fundamental para a independência da revista, de acordo com editorial assinado por Frei Betto de número 20. "Por razões éticas, não posso figurar em nenhuma direção, conselho ou assessoria. Sobretudo tratatando-se de um órgão de imprensa que, em sua justa liberdade, poderá conter algum artigo de crítica ao governo a que sirvo".

Seu primeiro número surgiu na Argentina durante as homenagens ao aniversário da morte de Che Guevara, em 1997. Além de artigos e reportagens com muito trabalho analítico, organiza seminários internacionais com debates de temas polêmicos e atuais, convidando à participação de personalidades de esquerda da América Latina. Em dezembro de 2000, o seminário foi realizado no Brasil e discutiu alternativas para o socialismo; em 2003 a sede foi no Chile. A América Libre é a principal revista da imprensa alternativa latino-americana em termos de pauta sobre o continente. No número 22, uma reportagem especial dedicou-se aos 30 anos do golpe contra Salvador Allende no Chile.

A distribuição, apesar de ser latino-americana, o que é um gigantesco feito, é restrita a círculos intelectuais e universitários. O grande meio de divulgação são os seminários. Mantém também uma página na Internet para divulgar os artigos e incentivar a assinatura (www.nodo50.org/americalibre).

JORNAL dos Trabalhadores Rurais SEM TERRA - Publicação mensal do maior movimento social do Brasil, o MST. É dedicada para a base do movimento - trabalhadores rurais, pequenos proprietários falidos e trabalhadores urbanos desempregados. Retrata o dia-a-dia do movimento, as experiências de sucesso nos assentamentos, as lutas nos acampamentos, além de fatos da política nacional e internacional. Traz entrevistas com personalidades da cultura, das ciências e do MST. Tem assinatura mensal e é vendido em 
livrarias especiais e na loja do movimento em São Paulo. No formato tablóide, a capa e quarta capa são coloridas. O cuidado com a diagramação e revisão das matérias é satisfatório, o que mostra o profissionalismo da equipe que o produz. A tiragem é de 40 mil exemplares e traz uma versão na Internet (www.mst.org.br). Para enfrentar a ofensiva da mídia oficial e do governo, no ano de 2000 , com constantes ataques ao movimento, o MST lançou algumas edições especiais do jornal, com quatro páginas em formato standard coloridas, dedicadas exclusivamente para contra-atacar as matérias da grande imprensa.

REVISTA SEM TERRA - Publicação trimestral do MST, é dedicada para simpatizantes, militantes de outros movimentos e também para a base. Trata dos mesmos assuntos abordados no Jornal Sem Terra, porém de maneira mais profunda com matérias longas, análises e entrevistas. Impressa em papel couché 2 cores, formato A4, com cerca de 100 páginas. A diagramação, revisão e tratamento gráfico são excelentes. A publicação, no entanto, peca na periodicidade: por dificuldades financeiras - a revista conta com apoio e anúncios em permuta com outros veículos da linha - ela não consegue manter a periodicidade de três meses, que poderia ser encurtada. Traz colunistas de qualidade Alípio Freire, Hamilton de Souza, editor da revista, Emiliano José, Otto Filgueiras, Walter Pomar, e reserva espaços para a cultura e matérias internacionais.

AGÊNCIA DE NOTÍCIAS DO MST - No site do MST, é um mural de notícias dos assuntos de interesse do movimento e também de política internacional.

RÁDIO VOZES DA TERRA - Mais uma inovação do MST. Produzida em parceria com estudantes universitários a rádio noticia os principais eventos realizados pelo movimento, como a Marcha para Brasília. As edições especiais são temáticas (agricultura orgânica e educação, por exemplo). Os programas podem ser escutados pela Internet, na página do movimento (www.mst.org.br). 
CAROS AMIGOS - Revista mensal brasileira, da editora Casa Amarela, que também edita livros e fascículos. A revista é o carro-chefe da editora e sobrevive praticamente sem anúncios a não ser por pequenas permutas com outras publicações e editoras, como a Expressão Popular. No seu corpo de redação tem nomes importantes como José Arbex, Sérgio de Souza, Renato Pompeu e Emir Sader, além de diversos colunistas renomados como Ferréz, que se tornou conhecido após a publicação de livros sobre a periferia da Zona Sul de São Paulo.

Os números especiais, as reportagens e as entrevistas de capa são assuntos que normalmente não ganham espaço na mídia e dizem respeito a cultura, política, economia e relações internacionais. No seu oitavo ano, tem circulação nacional, é vendida em banca e por assinatura e algumas matérias são veiculadas na Internet. Em 2000 a revista lançou uma coleção de 24 fascículos entitulada Rebeldes Brasileiros - homens e mulheres que desafiaram o poder, dentro da linha de desmascarar a historiografia oficial e, mais recentemente, lançou a série História Imediata. O objetivo desses fascículos é contribuir para a pesquisa e aprimoramento intelectual do público leitor.

É uma publicação lida especialmente por intelectuais e estudantes universitários e pós-graduados. Com tiragem média de 50 mil exemplares, de acordo com dados levantados em pesquisa encomendada pela editora, sua circulação é multiplicada, graças às polêmicas publicadas e às entrevistas com personalidades da América Latina.

ALAI (www.alainet.org) - Agência Latino-americana de informações. Bilíngüe, junto com a agência Adital, é a agência alternativa de informações da América Latina. Traz conexões com vários sites sobre a região e é atualizada com notícias sobre movimentos sociais e de violação aos direitos humanos.

De acordo com o editorial da agência, o trabalho da ALAl está inserido na ação pela democratização da comunicação como condição para a justiça social. O site é construído com apoio de organizações do Canadá (Centro Internacional de Pesquisas para o Desenvolvimento - CIID/IDRC) e da Holanda (Instituto Humanista para a Cooperação com 
Países em Desenvolviemnto -Hivos). "A ALAl está comprometida com a consolidação e defesa do Direito à Comunicação. Impulsiona atividades de sensibilização pública, elabora propostas de sustentação e lobby nos espaços de decisão. Dá uma atenção particular à questão de gênero e ao desenvolvimento de redes alternativas. Neste marco, ALAI vigora as iniciativas acertadas com entidades afins" ${ }^{\text {151. }}$.

Além da agência na Internet, a ALAI mantém uma publicação impressa mensal chamada América Latina en Movimiento de atualidades do pensamento latino-americano. Pelo site, é possível fazer a assinatura da publicação. Há também uma série de publicações chamada Subsídios para o debate sobre temas relativos à discriminação social, econômica, de gênero e racial.

ADITAL - Agência Frei Tito de Informação para a América Latina (www.adital.com.br) - Premiada pelo Unicef em 2005, a Adital nasceu em 1999 com o objetivo de pautar a mídia internacional com a agenda social latino-americana e caribenha. Assim, como a ALAI, a Adital recebe o financiamento de entidades internacionais, no caso, italianas: a Fundação Rispetto e Paritá, a Agência de Notícias Adista, a Rede Radiè Resch. O nome é uma homenagem ao dominicano Frei Tito de Alencar, que se suicidou em 1974, conseqüência das torturas sofridas durante a ditadura militar brasileira. A sede da agência fica em Fortaleza, no Nordeste brasileiro.

A Adital conta com uma rede de correspondentes em vários países da América Latina, o que garante a cobertura da América Central, caribe, da América Andina, da América Amazônica e do Cone Sul. Entre os colaboradores da Adital estão integrantes do terceiro setor, militantes de movimentos sociais e de organizações defensoras de direitos humanos, professores e alunos de universidades, emigrantes, povos inídigenas, negros e comunidades de resistência e pastorais de diferentes igrejas e tradições religiosas.

O trabalho da Adital gera frutos. São 15 mil endereços eletrônicos que recebem as notícias em português e em espanhol. No mês de março de 2005, de acordo com a agência, ${ }^{151}$ ALAl. Agência Latino-Americana de Informações. Disponível em www.alainet.org. Acesso em: 02 maio 05 . 
foram 265 mil acessos. A Unesco premiou a agência como uma das 20 melhores iniciativas de comunicação na América Latina. Em abril do mesmo ano, a agência também recebeu o prëmio Don Hélder Câmara de Imprensa, na categoria Grande Mídia, concedido pela Conferência Nacional de Bispos do Brasil (CNBB).

REVISTA FÓRUM - Outra iniciativa originada do Fórum Social Mundial, na versão impressa, vendida em bancas e por assinaturas tem artigos e reportagens sobre a América Latina. Tem uma edição eletrônica e um boletim chamado Lado B, enviado aos cadastrados. Como o jornal Brasil de Fato é sustentada pela colaboração de sindicatos e movimentos sociais.

Há veículos da imprensa alternativa que são órgão oficiais de movimentos com menos impacto no Brasil que o MST e partidos políticos brasileiros ou cubanos, como o Gramna.

GRANMA e GRANMA INTERNACIONAL - Lendário jornal cubano, é o órgão oficial de comunicação do Partido Comunista Cubano, diário (Granma) e de periodicidade mensal (Granma Internacional). O Granma Internacional é publicado em português, francês, alemão e inglês. Em razão da solidariedade internacional, vários países cuidam da sua distribuição. Vale para conhecer as dificuldades, lutas e sucessos da ilha. Em formato tablóide, é impresso em papel jornal, comduas cores na capa e quarta capa. Também tem versão na Internet: www.granma.cu.

Jornal VOZ e Revista RESISTENCIA - Publicações colombianas, o jornal Voz é o órgão oficial de comunicação do Partido Comunista Colombiano e a revista é o veículo de comunicação das FARC (Forças Armadas Revolucionárias da Colômbia).

Em 32 páginas coloridas, a revista Resistência é editada pela Comissão Internacional das FARC. Serve de contraponto para as matérias publicadas na grande imprensa que caracterizam as FARC como narcotraficantes. O editorial é feito a partir da palavra de ordem de Simón Bolívar: "Una sola debe ser la patria americana". Entre as 
reportagens do número 32, grande parte é referente à luta das FARC contra o governo colombiano, mas também há espaço também para lutas de outros países latino-americanos. É preciso dar destaque para as matérias "Los camaleones de la muerte" sobre os paramilitares da Colômbia; "Invasión recolonizadora" sobre a invasão do Iraque pelos EUA; "Una espada recorre el continente" e "A Bolívia la acaricia el mar" sobre a Bolívia; "Crisis, Alca y recolonización" e "Si hay altenativa" sobre a ALCA e a ALBA (Alternativa Bolivariana para as Américas) e "Bastantes montañas hay aqui" sobre a Venezuela. ${ }^{152}$

VOZ REBELDE - O jornal é o veículo de comunicação do grupo guerrilheiro peruano MRTA (Movimento Revolucionário Tupac Amaru), que mantém constante luta contra o governo no Peru e segue a linha da luta armada para tomada do poder. O jornal tem denunciado os cárceres e os crimes contra os direitos humanos no Peru.

REPORTAGEM - Revista editada por uma cooperativa de colaboradores chamada Oficina de Informações, destaca-se por grandes reportagens de temas polêmicos como o muro que divide EUA e México, ou personalidades como o presidente da Venezuela, Hugo Chávez. Da mesma equipe que já fez as revistas Opinião e Movimento, peca na distribuição, na propaganda para militantes e na periodicidade, devido a dificuldades financeiras.

CORREIO DA CIDADANIA - Publicação brasileira mantida pela Sociedade para o Progresso da Comunicação Democrática. Tem o objetivo de oferecer uma visão crítica dos acontecimentos citados pela grande imprensa. No editorial publicado na Internet, o Correio diz que não vive do dinheiro de "anunciantes e seus interesses econômicos", por isso pede a colaboração dos leitores por meio de depósitos bancários.

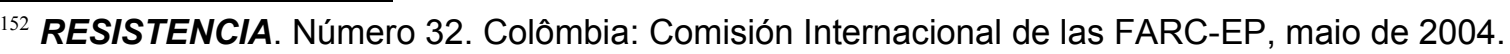


AGÊNCIA CARTA MAIOR (www.agenciacartamaior.com.br) - Com hospedagem no portal de grande imprensa UOL e com patrocínio da Ford Foundation e da Petrobras, a Agência Carta Maior, assim como o jornal Brasil de Fato, nasceu sob a inspiração do Fórum Social Mundial, no caso o I Fórum. Tanto que o símbolo da agência é um globo terrestre com o Sul cartográfico na parte superior e girando no sentido anti-horário como demonstração de que outro mundo é possível. Sua equipe é formada por jornalistas, profissionais técnicos e colaboradores em diversas capitais e países da América Latina e Europa.

"A escolha da data não foi casual. Os princípios editoriais que norteiam nosso trabalho estão
afinados, entre outras coisas, com o ideário que anima o movimento internacional que deu
origem ao FSM. Nosso compromisso é contribuir para desenvolver um sistema de mídia
democrática no Brasil e, de modo mais amplo, trabalhar pela democratização do Estado
brasileiro, pelo fortalecimento da integração sul-americana e de todos os movimentos que
lutam pela construção de uma globalização solidária. Especializada em temas como direitos
humanos, meio ambiente, política, economia e movimentos sociais, um dos principais focos
da Agência, em função mesmo de sua origem, é o processo Fórum Social Mundial.
Produzimos uma média de 200 matérias por FSM e cerca de 50 nos fóruns temáticos,
regionais e preparatórios. Ao longo destes últimos quatro anos, fomos constituindo aquele
que seja possivelmente o maior acervo de vídeo e texto relativo ao processo FSM. A maior
parte destes textos está publicada em português, inglês e espanhol." 153

Além da ADITAL, ALAl e Agência Carta Maior, há outras agências de notícias alternativas na Internet:

APC (www.apc.org) - A APC (Asociación para el Progreso de las Comunicaciones) é uma agência alternativa de notícias da América Latina. A APC tem filiais em vários países latino-americanos como Uruguai e México. O objetivo é desenvolver tecnologias para o uso estratégico da informação.

AGÊNCIA PÚLSAR (www.pulsar.org) - Agência Púlsar de notícias alternativas de rádio e imprensa, de distribuição gratuita, é uma iniciativa da Associação Mundial de Rádios Comunitárias da América Latina e Caribe. A sede fica em Buenos Aires e, desde 1995, envia informações por correio eletrônico aos leitores cadastrados no site.

BOL PRESS (www.bolpress.com ) - Agência alternativa de notícias boliviana.

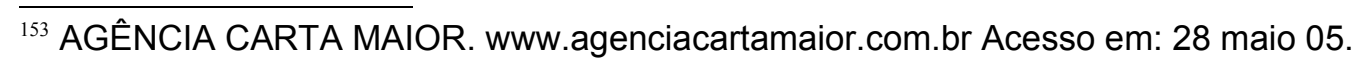




\subsubsection{1 - A mídia alternativa na Internet}

Apesar de a Internet não ter se revelado o meio democratizante e capaz de empreender uma revolução na ordem internacional da comunicação ${ }^{154}$ e tampouco ser um meio representativo dos camponeses, operário e de todos os solitários da América Latina, é importante citar alguns exemplos de páginas na Internet que se mantém por um longo período (não apresentam a caducidade de outros sites) e podem servir de referência para pesquisas, divulgação de manifestos ou debates.

WWW.EZLN.ORG - A página do Exército Zapatista de Libertação Nacional, do México, foi a grande prova de que um movimento social pode ganhar simpatia e apoio internacional por meio da Internet. Os comunicados do subcomandante Marcos, os boletins relatando a situação da luta e as ofensivas do governo eram distribuídos e multiplicados mundialmente por meio de e-mails e pela própria página. Foi com o exemplo do EZLN que outros movimentos criaram coragem para colocar suas páginas no ar. No site podem ser encontrados todos os comunicados, fotos e a história do movimento.

WWW.MADRES.ORG - Associação Mães da Praça de Maio, com a história, documentos cartas, denúncias e notícias das desaparições a partir de 1974, na Argentina.

WWW.DESAPARECIDOS.ORG- Página do Projeto dos Desaparecidos nas ditaduras militares da América Sul e as atrocidades cometidas por Pinochet e demais forças de segurança.

WWW.AMNESTY.ORG - Anistia Internacional, trabalha pela libertação de presos políticos e pelo julgamento rápido e justo dos presos de consciência, abolição da pena de morte e da tortura.

${ }^{154}$ BORN, Margarethe Steinberger-Elias. Discursos Geopolíticos da Mídia: jornalismo e imaginário internacional na América Latina. São Paulo: Cortez, 2005. 
WWW.DERECHOS.ORG/NIZKOR - A melhor página sobre direitos humanos na América Latina, com artigos, debates, espaço para denúncias, lista dos desaparecidos políticos em todos os países e links com outras páginas.

WWW.LANETA.APC.ORG/CDHBCASAS - O Centro de Direitos Humanos Frei Bartolmé de Las Casas é uma ONG criada pela Diocese de Chiapas, com informes de violações dos direitos humanos e análise sobre a Guerra em Chiapas. 


\section{2 Óculos de patrões e empregados: o caso dos jornalistas a serviço da repressão}

A história da humanidade é a história das lutas de classe. Nas diversas categorias de trabalhadores é clara a distinção entre quem é patrão e quem é empregado. Simplificando as complexas teorias, o operário que constrói o shopping center e os prédios das escolas particulares sabe que não poderá consumir os produtos ali vendidos ou que seus filhos não vão se matricular naqueles colégios. Ou seja, as forças produtivas sabem que, dentro do capitalismo, não serão detentoras dos meios de produção e nem dos seus produtos simbólicos.

Essa clara separação também está presente na empresa jornalística. Os jornalistas nas redações sabem que não pertencem às famílias Marinho, Civita, Frias ou Mesquita e não são proprietários dos jornais. Por mais que alguns jornalistas sonhem em ter seus próprios veículos de comunicação, é senso comum que a tarefa não é fácil. Um clássico exemplo é o sonho de Samuel Wainer de ter seu próprio jornal que só foi realizado quando o patrocínio estatal político e econômico veio de Getúlio Vargas.

Entretanto, a história do jornalismo brasileiro guarda episódios em que os jornalistas da redação se confundem com seus patrões nas tarefas ideológicas. Não é o objetivo desta dissertação esmiuçar e explicar o fenômeno, pois é um complexo estudo de história social do trabalho que ainda necessita de mais pesquisas. A revista Veja é um excelente caso de como o corpo da redação assume a ideologia do grupo econômico que sustenta a Editora Abril. O senso comum diz que é a luta pela permanência no emprego, mas senso comum não é argumento científico. Há muito mais fatores e atores que explicam essa simbiose entre patrões e empregados nas empresas jornalísticas e a Comunicação Social é carente dessas análises.

Um trabalho muito interessante e necessário nessa linha de pesquisa é o de Beatriz Kushnir. Pesquisadora da área da História Social, Beatriz publicou Cães de Guarda: jornalistas e censores do Al-5 à Constituição de 1988 (Boitempo, 2004), livro que trata 
do colaboracionismo de alguns jornalistas com a censura e repressão durante a ditadura militar brasileira. Como foi dito, não é objetivo desta dissertação detalhar esse fato, mas ele é ilustrativo do processo de "unificação" dos óculos de jornalistas e proprietários dos meios de comunicação. Serve para mostrar como um jornalista adota as mesmas características de seleção de notícias que o grupo detentor do veículo, ou seja, como um jornalista que não pertence à elite latino-americana adota os mesmos discursos e práticas.

Depois da decretação do Ato Institucional número 5 e da utilização de técnicas de tortura mais "científicas" (que não matavam o torturado nas primeiras horas de pancadaria, após as quais era colhido seu depoimento), a repressão conseguiu destruir efetivamente a resistência armada no país. Marighella e Lamarca, os maiores símbolos da guerrilha apontados pelo regime, foram assassinados em 1969 e 1971, respectivamente.

Mesmo assim era preciso garantir a continuação do governo autoritário, principalmente pela sustentação do "milagre econômico" que só era milagre nas páginas dos jornais. A censura prévia foi estabelecida desde as primeiras horas do regime e vigorou até 1975. A partir desse momento, a censura ficou a cargo dos próprios jornais. A tese de Beatriz Kushnir era de que os jornalistas já estavam adestrados o suficiente para saber, por conta própria, o que poderia e o que não poderia ser publicado.

O movimento foi uma espécie de "presente" da ditadura aos meios de comunicação, que estavam se inviabilizando economicamente pela censura prévia, primeiramente porque os anunciantes fugiam de veículos perseguidos e cortados a todo instante e também porque havia uma burocracia que determinava o envio das matérias para Brasília. Só depois dos cortes que o jornal poderia ir para as bancas, o que "envelhecia" o noticiário.

Esse presente deveria ser agradecido pelos jornais com responsabilidade. "Para os grupos de interesse que o chefe do Sigab (Serviço de Informação do Gabinete) representava, o ato censório, naquele momento e apenas em alguns jornais, não mais precisava da figura presente do censor. Censurar já deveria ser uma demanda introjetada, permanecendo dentro da cabeça dos 'homens dos jornal'". 155

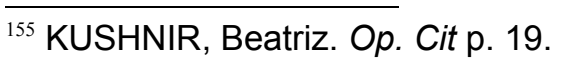


A pesquisadora faz uma ressalva de que o colaboracionismo não foi uma prática de todos os jornalistas, que muitos perderam os empregos, foram perseguidos, presos, exilados ou mortos, mas, por outro lado, também houve os que não combateram. O centro do estudo de Beatriz Kushnir é o seguinte:

"A existência de jornalistas que foram censores federais e que também foram policiais
enquanto exerciam a função de jornalistas nas redações. Escrevendo nos jornais ou
riscando o que não poderia ser tido ou impresso, colaboraram com o sistema autoritário
implementado naquele período. Assim como nem todas as redações eram de esquerda,
nem todos os jornalistas fizeram do ofício um ato de resistência ao arbítrio [...] O eixo desta
apreciação ancora-se em um território do qual participava apenas um pequeno grupo
dirigente e de jornalistas nas redações. Estou estudando jornalistas colaboracionistas, cães
de guarda! [...] Este é um estudo que toca na questão da ética, mas centra-se na prática de
um ofício, nas regras a serem seguidas e, sobretudo, nos seus momentos de rompimento
da prática e da conduta."156

O estudo se divide em dois. De um lado os jornalistas de formação e profissão que trocaram as redações pela burocracia e se tornaram técnicos de censura subordinados ao Estado repressor; de outro, policiais de carreira que atuaram como jornalistas, colaborando com o sistema repressivo. O jornal Folha da Tarde, do grupo Folha da Manhã, é batizado pela autora como o "jornal de maior tiragem do país", devido à quantidade de policiais e jornalistas colaboracionistas. A Folha da Tarde foi um instrumento de apoio e propaganda do Estado autoritário e foi conhecido como o "Diário Oficial da Oban". O editor-chefe do jornal, Antonio Aggio Jr, prestou concurso na Secretaria de Segurança Pública em 1962 e foi escriturário lotado na Delegacia Geral de Polícia. Além disso era afilhado do coronel Antônio Lepiane - o comandante do IV Regimento de Infantaria de Quitaúna, em 1967. Mais tarde, foi secretário de Romeu Tuma - ex-delegado do DOPS - durante sua gestão como diretorgeral da Polícia Federal.

Interessante é notar que o grupo Folha da Manhã é o mesmo que edita a Folha de S.Paulo, jornal que se vangloria de ser o porta-voz do Movimento das Diretas Já, por ser o primeiro veículo a noticiar o assunto e, em função disso, por ser plural e democrático. O discurso, na verdade, faz parte do processo dos empresários Octavio Frias de Oliveira e

${ }^{156}$ Idem. Op. Cit. p 26-8. 
Carlos Caldeira Filho de levar o grupo Folha à liderança das empresas jornalísticas no melhor estilo Cidadão Kane.

O livro de Kushnir, especialmente no capítulo referente à Folha da Tarde relata várias relações entre proprietários de jornal e políticos da base de sustentação do regime autoritário. Entre elas a amizade do sinistro Erasmo Dias com Carlos Caldeira, que por sua vez foi nomeado prefeito biônico de Santos durante a gestão do governador Paulo Maluf.

"Em outras ocasiões, também se podiam encontrar os coronéis Lepiane e Éramos Dias, o governador Paulo Maluf, os delegados do Deops paulista Celso Telles e Romeu Tuma, os donos do Grupo Folha e todos os editores dos jornais da empresa, entre muitos outros políticos e militares, nos almoços de aniversário do jornal, comemorados sempre no dia $1^{\circ}$ de julho."157

Essas relações promíscuas não são exclusividade da época do totalitarismo. Em todos os governos civis latino-americanos a concessão de rádios, TVs e apoio a jornais são moeda corrente e não geram nenhum editorial de repúdio na grande imprensa. Ao contrário da união das esquerdas latino-americanas, classificadas como "risível patuscada de repúblicas bananeiras" pelo semanário brasileiro Veja ${ }^{158}$.

O livro de Beatriz Kushnir relata os últimos anos da ditadura militar. Mas a figura dos cães de guarda não desapareceu por completo. Não são mais policiais de carreira, mas outros integrantes dos grupos pertencentes às elites latino-americanas que se tornam "diários oficiais" da repressão às classes populares. Durante a fase mais repressora do governo Fernando Henrique Cardoso ao Movimento dos Trabalhadores Sem Terra, a revista Veja estampou na capa a manchete "A Tática da Baderna"159. A "reportagem“ de Eduardo Oinegue colocava o movimento (a maior manifestação de esquerda na América Latina nas palavras da revista Caros Amigos) como um grupo de bandidos. Em um box uma foto montagem de um dos líderes do movimento, João Pedro Stédile, com o agente 007 James Bond, de arma em punho. No olho do box, a ironia: se o agente 007 tinha licença do governo britânico para matar, os integrantes do MST também se sentiriam autorizados a

\footnotetext{
${ }^{157}$ Idem. Op. Cit. p 320.

${ }^{158}$ SHELP, Diogo. O Clone do Totalitarismo. In: Veja. Edição 1903 - ano 38 - n 18. São Paulo: Editora Abril, 4 de maio de 2005. p. 156.

${ }^{159}$ OINEGUE, Eduardo. Sem Terra e Sem Lei. In: Veja. Edição 1648 - ano 33 - n 19. São Paulo:

Editora Abril, 10 de maio de 2000. p 42-9.
} 
cometer diversos crimes como violação de domicílio, formação de quadrilha, corrupção de menores, furto e cárcere privado.

Dentre as fotos, uma fazia a comparação entre um soldado americano "devidamente paramentado" para enfrentar multidões e um policial brasileiro. Para Oinegue a "diferença é gritante" a favor do americano, que parece um soldado do futuro numa guerra com todas as formas de camuflagem e proteção possíveis. O ângulo da foto o coloca como uma espécie de Robocop, enquanto o brasileiro tem "apenas" um colete à prova de balas e não usa capacete. Não são necessárias análises de discurso ou conteúdo extensas para mostrar como Oinegue concebe a relação com os movimentos populares. Para o então repórter da Veja, quanto mais repressivo, melhor. Para ele, para a Veja e para o governo da época, o MST era um grupo de bandidos e qualquer coisa que não fosse um coturno amassando as costas dos trabalhadores deitados no chão era insuficiente. 


\section{Informação e opinião}

Tanto Bourdieu quanto Beatriz Sarlo concordam que a TV é o veículo de comunicação que mais influencia o campo jornalístico. Ambos os autores citam episódios com os quais os demais veículos ou instituições só se preocupam quando a TV demonstra se interessar pelos fatos. De acordo com Bourdieu ${ }^{160}$ hoje "caminha-se cada vez mais rumo a universos em que o mundo social é descrito/prescrito pela televisão. A televisão se torna árbitro do acesso à existência social e política. Suponhamos que hoje eu queira obter o direito à aposentadoria aos 50 anos. Há alguns anos, eu teria feito uma manifestação, teríamos carregado cartazes, teríamos desfilado, teríamos ido ao Ministério da Educação Nacional; hoje é preciso contratar um bom consultor em comunicação. [...] se obtém, pela televisão, um efeito que pode não estar longe do que seria obtido por uma manifestação de 50 mil pessoas".

A TV como árbitro do acesso à existência social e política também é descrita por Beatriz Sarlo num episódio em que um suposto assassino corre a uma emissora de TV para fazer uma confissão pública e "encontra ali, mais garantias do que na institiuição policial: maior velocidade da máquina burocrática, maior segurança pessoal, ajuda para família, um advogado gratuito. Paternalismo televisivo numa época em que o paternalismo político, nas grandes cidades, já não pode garantir o intercâmbio de serviços que antes implementava. No lugar do caudilho político, que fazia a mediação entre seus seguidos e as instituições, a estrela televisiva é uma mediadora sem memória, que esquece tudo entre um intervalo comercial e outro". [...] Como os solitários que vão à televisão em busca de namoradas, os esquecidos e os rejeitados procuram nela o ouvido que não encontraram em nenhuma parte". ${ }^{161}$

No Brasil, a Rede Globo teve o papel de construir a imagem do país por meio dos noticiários nacionais e das telenovelas. A rede foi construída com esse objetivo e tenta cumpri-lo até hoje. Quando foi criada durante a ditadura militar (1964-85), a TV Globo

${ }^{160}$ BOURDIEU, Pierre. Op. Cit. p.29.
${ }^{161}$ SARLO, Beatriz. Op. Cit. p 78-9. 
transmitia a imagem de um país organizado, que rumava para o desenvolvimento. $O$ objetivo do governo militar era incentivar o desenvolvimento de uma rede de dimensões continentais que alcançasse todo o país com um único discurso. A Rede Globo servia de porta-voz dos militares mesmos nos lugares mais longínquos, aonde o Estado não conseguia chegar de maneira intensiva, e que poderiam ser alvo de atuação de grupos guerrilheiros de esquerda. Pela TV, os militares transmitiam a imagem de um país em calmaria, mesmo que nos porões a tortura e a violência seguissem aniquilando as tentativas de oposição.

Como nesse caso, muitas vezes, o país retratado nas telas não corresponde ao real, mas ao que a ideologia da emissora considera que deve ser real. Novelas ambientadas no Rio de Janeiro evitam tocar em assuntos como violência, tráfico de drogas, prostituição. Quando o fazem é sempre por meio da idealização. O número de personagens negros não reflete o que se vê na realidade da população brasileira. A maioria dos protagonistas das histórias novelescas pertence à classe média-alta. O mundo pobre, quando tem espaço, é também fantasiado. As moradias, os veículos de transporte, os locais de lazer e trabalho nada têm a ver com o cotidiano brasileiro (incluindo o da classe média), nem mesmo com o do carioca, grande personagem dos folhetins televisivos.

A autora Beatriz Sarlo diz que a "TV é mimética: constrói seu público a fim de poder refleti-lo, e o reflete para poder construí-lo. A televisão e o público estabelecem um pacto de um programa mínimo, tanto do ponto de vista estético quanto do ponto de vista ideológico". 162

Da mesma forma, o telejornalismo - no Brasil sediado no Rio de Janeiro - constrói um mundo diferente do visto nas ruas. Os telejornais são recheados de assuntos ônibus. O toque de realidade dos noticiários de TV seria dado pelas reportagens de helicóptero que apelam para o sensacional: acidentes, ocorrências e perseguições policiais, atendimentos médicos de emergência, catástrofes naturais como deslizamentos e enchentes, rebeliões em presídio, etc. Quando um programa de rádio ou TV chama "o departamento de

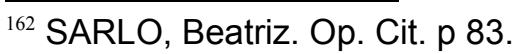


jornalismo da emissora", a atenção do público imediatamente é convidada a prestar atenção, pois a palavra "jornalismo" denota seriedade, informação, prestação de serviço. Porém, nem sempre é isso que acontece. Logo após a chamada do "departamento de jornalismo", muitas vezes o que aparece é um helicóptero que tenta flagrar algum acontecimento sensacional que aumente a audiência, ou, na falta destes acontecimentos, que chama alguma matéria de gaveta (material de arquivo) que tenha gerado grande repercussão.

Novamente, vale lembrar que este processo não é apenas uma espécie de "teoria da conspiração" promovida pelos proprietários das emissoras de TV. Para Bourdieu, "quanto mais um jornal estende sua difusão [ganha audiência] mais caminha para assuntosônibus.[...] É o que faz com que todo o trabalho que tende a homogeneizar e a banalizar, a conformizar e a 'despolitizar', convenha perfeitamente, embora ninguém Ihe seja o sujeito, embora ele jamais seja pensado e desejado como tal por quem quer que seja". ${ }^{163} \mathrm{Na}$ visão de Sarlo, "a televisão faz circular tudo o que pode ser convertido em assunto: desde os costumes sexuais até a política. E também reduz à poeira do esquecimento os assuntos de que não trata: desde os costumes sexuais até a política."164

O tempo (ou o espaço) é vital no jornalismo. Portanto, se tempo e espaço tão preciosos são preenchidos com temas tão vazios é porque essas futilidades ocultam "coisas preciosas". Beatriz Sarlo, no mesmo raciocínio, afirma que a TV está presa ao espelho do nível de audiência. "A televisão não pode senão propor uma cultura do espelho, onde todos possam reconhecer-se. Esse 'todos' configura justamente o sujeito ideal televisivo: o número mais amplo possível é o target das emissoras". ${ }^{165}$

Para Adelmo Genro Filho, este processo de homogeneização das notícias faz parte da transformação do jornalismo opinativo em jornalismo informativo, adotado hoje no Brasil como "jornalismo por excelência". Ou seja, um jornalismo que não deveria dividir opiniões, não adotar uma postura crítica ou política em determinados fatos para não afastar o leitor.

\footnotetext{
${ }^{163}$ BOURDIEU, Pierre. Op. Cit. p. 63.

${ }^{164}$ SARLO, Beatriz. Op. Cit. p. 83-91.

${ }^{165}$ SARLO, Beatriz. Op. Cit. p 82.
} 
Cria-se o mito da objetividade, uma das primeiras palavras aprendidas nos cursos superiores de jornalismo e nos manuais de redação. A tese de Genro Filho é que a inclusão de acontecimentos banais e a ausência de posicionamento político atendem às necessidades capitalistas das indústrias de comunicação. É preciso vender mais jornal, ter mais telespectadores e ouvintes para garantir maior renda publicitária. A equação é a mais antiga do jornalismo. Posicionamentos ideológicos explícitos espantam ou dividem o público.

\section{1 - O mito da imparcialidade}

O jornalismo nasceu com o renascimento comercial, como forma de divulgação e troca de informações entre a burguesia nascente que se encontrava nas feiras comerciais e precisava de dados econômicos como a cotação das diferentes moedas. Dos folhetos de informações comerciais o jornalismo se tornou braço dos partidos políticos. ${ }^{166}$ Os jornais posicionavam-se politicamente em relação aos grupos que disputavam o poder.

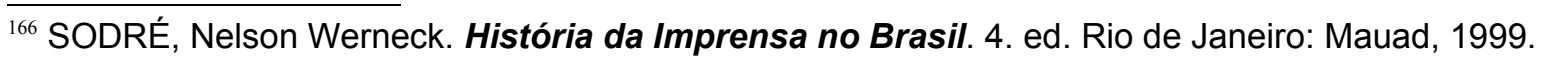


O historiador Nelson Werneck Sodré relata, no desenvolvimento da imprensa brasileira, desde a chegada da família real ao Rio de Janeiro, como os diversos veículos foram se alinhando a liberais ou conservadores, a republicanos ou monarquistas, a abolicionistas ou escravocratas, a trabalhistas ou udenistas.

Sobre os pasquins publicados durante o Primeiro Império, Sodré afirma que foi a fase mais romântica da imprensa brasileira, quando ela assumia abertamente suas posições sem máscaras que encobrissem sua ideologia. Os pasquins tinham o objetivo de desestabilizar o governo de D. Pedro I, e isso estava declarado em cada artigo publicado. Essa posição declarada só aconteceu novamente na grande imprensa quando Samuel Wainer com o Última Hora e Carlos Lacerda com o Tribuna da Imprensa se enfrentavam diariamente. ${ }^{167} \mathrm{O}$ Última Hora, pró Getúlio Vargas e o Tribuna da Imprensa, órgão que dava voz à UDN não se enfrentavam apenas nos editoriais, mas em todo o noticiário. Era claro qual jornal defendia o governo e qual era de oposição.

Após o desenvolvimento da indústria capitalista jornalística, o jornal não deixou de defender posições mas não podia explicitá-las. Os grupos familiares detentores dos principais veículos de comunicação brasileiros (Marinho, Frias, Mesquita, Bloch, Bittencourt, Levi, Civita) têm interesses a defender. Além de pertencerem a parcelas da sociedade oligárquica brasileiras, seus veículos são sustentados por outros grupos econômicos e políticos. Porém, como mostrou Adelmo Genro Filho, o caráter capitalista da imprensa brasileira adotou o lead e a objetividade como padrões de uma imprensa que pretende alcançar o maior número possível de receptores. ${ }^{168}$

A adoção do "jornalismo por excelência" ou jornalismo objetivo, prega que no noticiário os meios de comunicação devem atentar mais aos fatos e menos às opiniões, deixando estas para o editorial. Por isso, o jornalista deve escrever as notícias se atendo aos fatos, sem emitir juízos. É o que se ensina nos primeiros dias de qualquer curso

\footnotetext{
${ }^{167}$ LAURENZA, Ana Maria de Abreu. Lacerda x Wainer: o corvo e o bessarabiano. São Paulo: Senac, 1998.

${ }^{168}$ GENRO FILHO, Adelmo. O Segredo da - para uma teoria marxista do jornalismo. Porto Alegre: Editora Tchê, 1987. Op. Cit.
} 
superior de jornalismo. Porém, essa imparcialidade é um mito. O simples fato de começar o lead por uma de suas clássicas perguntas já denota a parcialidade do redator.

Como foi visto ao longo deste trabalho são inúmeros os fatores que interagem para alterar e modificar o processo de seleção de fatos e sua elevação à condição de notícia. Diante de tantos processos (história da sociedade, influência norte-americana, óculos dos jornalistas) a imparcialidade, que já é reduzida em qualquer espécie de texto, é impossível no jornalismo.

Apesar de adotar uma fantasia de um jornalismo objetivo, preso aos fatos, imparcial e plural, todos os veículos de comunicação são aparelhos ideológicos. Para Umberto Eco:

\begin{abstract}
"Hoje um país pertence a quem controla os meios de comunicação. [...] O que torna terrível o jornal não é (pelo menos: não é somente) a força econômica e política que o dirige. $O$ jornal como meio de condicionamento da opinião já tinha sido definido quando nasceram as primeiras gazetas. Quando alguém deve escrever diariamente tantas notícias quantas permite o espaço disponível, de modo que sejam legíveis por um público de gostos, classe social e instrução diferentes, em todo um território nacional, a liberdade de quem escreve já terminou: os conteúdos da mensagem dependerão não do autor mas das determinações técnicas e sociológicas do mídia." ${ }^{169}$
\end{abstract}

No tópico anterior foi visto que a mídia alternativa não utiliza o discurso da imparcialidade e nem deve cair nesta armadilha. A mídia alternativa pode estabelecer a guerra de guerrilhas contra a grande imprensa justamente ao adotar posições explícitas em relação aos fatos. Fica para a grande imprensa o papel de iludir o público receptor de que não é ligada a nenhum grupo político ou econômico e de que seu jornalismo é feito para toda a população. Entretanto, como também já foi visto, o discurso sobre esse tipo de jornalismo esconde a estratégia de ampliar o número de receptores e aumentar a receita publicitária, e encobre o fato de que a grande imprensa é feita pela elite para a elite.

Esse mecanismo perverso é facilmente desmontado por análises de conteúdo ou de discurso, até mesmo por análises superficiais. Uma rápida folheada na edição 1.903 da revista Veja, de 4 de maio de 2005, que tem como matéria de capa o presidente venezuelano Hugo Chávez mostra como a publicação, carro-chefe da Editora Abril, do grupo Civita, não é imparcial com relação à América Latina.

${ }^{169}$ ECO, Umberto. Guerrilha Semiológica. In: Viagem na irrealidade cotidiana. Rio de Janeiro: Nova Fronteira, 1984. p 165-6. 
A matéria, assinada por Diogo Schelp, faz comparações preconceituosas entre Fidel Castro e Hugo Chávez. Começa pela própria capa, toda em vermelho - recurso típico da Veja desde as primeiras críticas ao MST. A matéria surge não por acaso. Chávez polariza com Lula a liderança na América Latina. Porém, aos olhos da elite brasileira, a liderança de Chávez é nefasta, muito mais próxima a figura de Fidel Castro. A liderança de Lula, apesar de ser considerado um político de esquerda, é muito "palatável". Lula não quebrou de imediato os acordos com o FMI, segue a doutrina neoliberal de combate à inflação e não fez, ao contrário de algumas previsões fatalistas, grandes alterações na estrutura capitalista do Brasil.

Chávez é considerado um monstro: utiliza a figura de Simón Bolívar em seus discursos, prega a união da América Latina na chamada ALBA (Alternativa Bolivariana para as Américas). É amigo de Fidel Castro e mantém relações comerciais com Cuba, o que já é um fato considerado abominável pela elite conservadora brasileira, que torce tanto quanto os gusanos de Miami pelo fim do regime na ilha. Chávez sofreu um frustrado golpe de Estado, que não durou 48 horas. Com apoio popular, voltou ao poder ainda mais forte. Convocou e venceu um plebiscito popular para sua permanência na presidência da Venezuela. Apóia diversos movimentos sociais pela América Latina como o MAS (Movimento ao Socialismo) liderado por Evo Morales, o líder cocalero boliviano. Estas ligações com as esquerdas latino-americanas são vistas como pânico pelas elites brasileiras. Sobretudo porque Chávez mantém uma política de crítica à política externa dos EUA e, o que mais choca as elites brasileiras, de combate aos privilégios oriundos do petróleo para a elite venezuelana.

O exemplo de Chávez deve ser combatido pela elite conservadora brasileira. É um perigo vermelho muito maior do que Fidel Castro aos olhos de Veja, que, numa matéria de 10 páginas recolhe uma série de argumentos para comprovar o quanto o governo da Venezuela é ditatorial, corrupto e nocivo à paz latino-americana. De acordo com o editorial, a capa de Veja foi escolhida, porque era a melhor reportagem dentre várias que a chefia poderia escolher. As outras duas seriam sobre o tamanho do Estado brasileiro (a figura do 
elefante outrora utilizada para justificar o processo de privatização durante a primeira onda neoliberal voltou a aparecer) e sobre o lançamento do filme épico As Cruzadas. A semana de publicação dessa edição foi a mesma em que Fidel e Chávez proclamaram a criação da Alba e em que, Condoleezza Rice, secretária de Estado norte-americano visitava a América Latina. É muito "curioso" considerar que a matéria sobre a Venezuela era mais bem escrita do que as demais, principalmente levando-se em conta que a entrevistada das páginas amarelas era a própria Condoleezza.

Os manuais de redação pregam que o jornalismo objetivo e imparcial deve evitar adjetivos e expressões que conotem preconceito ${ }^{170}$. O Manual de Redação da Editora Abril define como o segundo, de três princípios:

"Como empresa, a Abril está empenhada em contribuir para a difusão da informação, cultura e entretenimento, para o progresso da educação, a melhoria da qualidade de vida, o desenvolvimento da livre iniciativa e o fortalecimento das instituições democráticas no país. Essa filosofia reflete-se no conteúdo de suas publicações, que não veiculam referências que possam ter conotações de preconceito racial, social ou religioso, nem de desrespeito aos direitos humanos universalmente aceitos." ${ }^{\text {171 }}$

No capítulo referente a "Estilo e Edição de Texto" o manual diz sobre adjetivos e advérbios: "Procure escrever seus textos com substantivos e verbos. Use apenas os adjetivos e advérbios necessários" 172 e na página seguinte, "Combata sem tréguas o exagero e a desinformação" 173 .

A matéria de Veja está carregada de adjetivos e não está livre de preconceitos. Na abertura da matéria, junto a uma foto de Chávez ao lado de Fidel Castro, ambos em uniformes militares, havia o seguinte texto:

“O presidente da Venezuela, Hugo Chávez, há mais de seis anos no poder, ameaça a estabilidade da América Latina com o financiamento e o apoio a grupos radicais de países vizinhos, a formação de uma milícia civil, o uso do petróleo para chantagear as

\footnotetext{
${ }^{170}$ MARTINS, Eduardo. Manual de Redação e Estilo de O Estado de S.Paulo. $3^{\text {a }}$ ed. São Paulo: O Estado de S. Paulo, 1997.

${ }^{171}$ EDITORA ABRIL. Manual de Estilo da Editora Abril: como escrever bem para nossas revistas. $13^{\mathrm{a}}$ ed. Rio de Janeiro: Nova Fronteira, 1990. p 15.

172 Idem. p. 34

${ }^{173}$ Idem. p. 35
} 
repúblicas da América Central e a aliança com a ditadura cubana de Fidel Castro, de quem se tornou um clone malfeito e extemporâneo".

O primeiro parágrafo da matéria era. "Curiosamente, o único presidente de países americanos que é uma bomba de efeito retardado, o coronel pára-quedista Hugo Chávez [...]. Veio do meio militar e tornou-se um populista autoritário e fanfarrão." No segundo parágrafo: "O coronel ainda não atingiu a sofisticação [...] de Fidel Castro, este sim [...] um fóssil da Guerra Fria que sobrevive em sua ilha particular como um capataz magnânimo, mas repressor".

Na página 156 da edição, o texto era: "Chávez demonstra necessidade quase patológica de se exibir como clone de Fidel Castro, o decano dos ditadores. Ambos se exibem em fardas militares e discursam por horas, misturando banalidades com assuntos de Estado. Não estivesse Caracas claramente substituindo Havana como quartel-general da insurgência revolucionária, tudo isso poderia ser mais uma risível patuscada de repúblicas bananeiras".

Não bastasse o uso de adjetivos depreciativos a matéria é ainda carregada de informações duvidosas, como o uso de aspas de Andrés Oppenheimer, considerado "respeitado especialista em América Latina", e colunista do Miami Herald que afirma ser "Chávez um Fidel Castro sem cérebro e com petróleo". Não é preciso grandes conhecimentos em geopolítica para saber que o Miami Herald é o jornal da comunidade anticubana de Miami.

Também está nos manuais de redação que o jornalista deve procurar os dois lados, expor as duas opiniões divergentes e deixar ao leitor a incumbência de decidir qual dos dois lados é o correto. Contudo, esse "mandamento" do jornalismo objetivo não existe aqui. Nem mesmo um especialista brasileiro sobre a América Latina foi entrevistado, que dirá um especialista que falasse algo a favor do governo Chávez.

Na mesma edição, nas páginas amarelas, uma das seções mais nobres da revista Veja, a secretária de Estado dos EUA é a entrevistada. Condoleezza Rice é considerada um 
falcão norte-americano, ou seja, é uma das burocratas estadunidenses que defendem a guerra a todo custo para a glória da nação ianque. Desde os episódios de 11 de setembro, foi árdua defensora da intervenção nos países do Oriente Médio, tanto que, após a saída do ex-general Collin Powell do cargo, por demonstrar fraqueza diante dos deslizes do exército norte-americano no Iraque (numa seqüência que começou com as denúncias de tortura nas prisões e culminou com o assassinato de um agente secreto italiano durante o resgate de um dos reféns de rebeldes iraquianos), ela era o melhor nome para devolver os EUA à posição de liderança na "cruzada contra o terror".

A entrevista tem o título de "Operação Simpatia", em alusão à tentativa de Rice de mostrar, nas palavras de Veja "a face mais humana do governo Bush". A foto, ao contrário da expressão carrancuda de Chávez em tom vermelho sob uniforme militar, traz a secretária sorridente sobre fundo azul, trazendo nas mãos uma bandeira brasileira e duas bolas de vôlei, uma delas autografada pelos atletas brasileiros vencedores da medalha de ouro nas Olimpíadas de Atenas.

Veja adota o carinhoso apelido de "Condi" e a descreve numa sucessão de adjetivos: "ela vem cruzando o planeta como a face mais humana do governo Bush e grande propagadora das vantagens da democracia". "Mesmo quando a missão inclui assuntos mais comezinhos [...] Condi tem se saído extraordinariamente bem”. E, ao contrário de Chávez, que foi classificado como fanfarrão e clone malfeito do totalitarismo, Condoleezza tem "uma espetacular história de sucesso que a precede [...] entrou na faculdade aos 15 anos, formouse aos 19, doutourou-se com 26. Pianista, especialista em relações internacionais e fluente em russo, chegou a reitora de Stanford".

Não existe imparcialidade. A edição número 1.903 de Veja é claramente contra as manifestações da esquerda latino-americana e mostra que o caminho a ser seguido é o exemplo norte-americano de sucesso. Chávez é o monstro enquanto "Condi" é o modelo de como se fazer política internacional. Ambas as matérias foram assinadas por editores. Jornalistas e patrões se confundem, mais uma vez. 
A revista Veja é lida pelo que se convencionou chamar de opinião pública e na verdade trata-se da elite dirigente política e econômica brasileira, inimiga de figuras do estilo de Chávez e simpática a dirigentes norte-americanos como Condoleezza Rice. São publicadas dezenas de estudos e análises de conteúdo ou de discurso de como a grande imprensa cobre determinados temas, exigindo delas imparcialidade e objetividade quando estes itens não existem. A grande imprensa é parcial e defensora de interesses políticoeconômicos.

Portanto, além da ideologia e da influência capitalista - via chefia - sobre os jornalistas (e que definitivamente é muito forte e exerce profundas edições na informação, ver o tópico 3 deste capítulo, a seguir) muito da manipulação que se pratica no jornalismo é feita quase que naturalmente nas redações. Não se questionam novas pautas porque elas não estão presentes no catálogo de consumo da América Latina Oficial.

Falta explicar o dia-a-dia das redações e propor alternativas quando os jornalistas ainda estão em formação e esta dissertação prossegue. Mas essa breve leitura de uma edição da Veja que, a olhos desavisados - noticia a América Latina, deixa evidente que a América Latina popular está cada vez mais solitária. Seu único espaço é, ainda, a imprensa alternativa. 


\section{Relações de trabalho nas redações}

A qualidade do Jornalismo, brasileiro e mundial, está em queda, como aponta Ignácio Ramonet, editor chefe do jornal francês Le Monde Diplomatique. "Podemos ver celebridades que assinam os grandes editoriais ou que apresentam os telejornais, mas por trás dessas estrelas se ocultam na verdade centenas de jornalistas que formam simplesmente o elenco de apoio. A informação tende a ser cada vez mais subtratada por jornalistas precários, à mercê da corvéia, que trabalham à sua maneira e fabricam uma informação sob encomenda" 174 .

Ao contrário do que se poderia imaginar a multiplicação da quantidade de programas “jornalísticos" não só na TV, mas também na Internet, não foi seguida de uma melhoria na qualidade do jornalismo. Há necessidade de cobertura imediata dos fatos, em tempo real, levando ao receptor o acontecimento praticamente na mesma hora em que acontece. Esse é um fenômeno mundial.

Nos Estados Unidos, em 1996, havia apenas três jornais noturnos, uma rede a cabo e dois programas semanais sobre um assunto. Em 1999, havia três jornais da noite, dez programas de uma hora sobre um assunto, três redes a cabo, três redes de informações econômicas, duas redes de informação esportiva e três sites na Internet com vídeoimagens. No Brasil, o mesmo acontece com programas esportivos, de variedades e de notícias "on-line".

"Isso poderia dar a impressão", argumenta José Arbex Jr., "de que a sociedade é beneficiada por uma pluralidade imensa de pontos de vista distintos, possibilitados pela disputa entre as empresas da mídia pela originalidade da notícia. Mas as coisas não acontecem assim: a sensação de 'falta de tempo' para entender a fundo os fatos estimula o recurso ao clichê, ao preconceito, à reiteração de concepções já formadas. É a cultura propícia à intolerância, à violência, ao racismo". ${ }^{175}$

As empresas de comunicação não investem na qualificação de seus profissionais. De acordo com Ramonet. "A rede americana NBC passou de três horas de informações por

\footnotetext{
${ }^{174}$ RAMONET, Inácio. Op. Cit.

${ }^{175}$ ARBEX JR, José. Op. cit.
} 
dia para vinte e sete horas no conjunto de seus canais, sem contar um site na Web, isto com apenas alguns jornalistas suplementares. Como qualquer proprietário de indústria, a NBC refletiu longamente na melhor maneira de tirar o máximo proveito de seus funcionários". Ramonet cita o depoimento de Ryszard Kapuscinski, que afirma que a profissão do jornalista mudou profundamente. "Antigamente o jornalista era um especialista, com algumas grandes figuras e efetivos limitados. Esse tipo de jornalista vem desaparecendo progressivamente. Basta olhar as assinaturas: não se conhece nenhuma. Mesmo na televisão, antes de chegar à tela, uma informação passa por dezenas de mãos, ela é cortada, fragmentada, para finalmente não ser identificada com nenhum autor. Ninguém é mais diretamente responsável". ${ }^{176}$

A profissão de jornalista é uma das mais castigadas. Nos primeiros dez meses de 2003, três jornalistas se suicidaram no Brasil ${ }^{177}$. A desqualificação do mundo do trabalho, no Brasil, atinge aos jornalistas em cheio. Enfraquecidos como classe, o sindicato dos jornalistas e a Federação Nacional de Jornalistas não participam ativamente dos grandes debates nacionais como acontece com o Sindicato dos Metalúrgicos ou como a Ordem dos Advogados do Brasil (OAB).

O Projeto Folha, cujas bases foram lançadas em 1981 dentro do jornal Folha de S.Paulo, iniciou um processo de "despolitização" das redações. O elevado grau de politização dos jornalistas foi trocado por uma ênfase na parte técnico-jornalística, aliada a uma reforma do parque tecnológico organizacional, incluindo a adoção de cronogramas e mecanismos industriais de controle e produção da notícia, que transformaram a redação numa linha industrial de produção em série, com o estabelecimento de um programa de metas e a contratação de jovens profissionais que ganham menos, exigem menos e submetem-se mais facilmente ao controle da direção do jornal. A rotatividade aumentou extraordinariamente. "A notícia se tornou uma mercadoria destinada a gerar lucros". ${ }^{178}$

\footnotetext{
${ }^{176}$ KAPUSCINSKI, Ryszard. Lapidarium, Milão, Feltrinelli, apud RAMONET, Ignacio. Op. cit. ${ }^{177}$ COMUNIQUE-SE.<Ww.comunique-se.com.br>. Acesso em: 10 maio 04.

${ }^{178}$ ARBEX JR, José. Op. Cit.
} 


\subsection{Transformações provocadas pela Internet: notícias em tempo real, aumento da pressão sobre os jornalistas, menor tempo de reflexão e apuração.}

Cada revolução tecnológica afeta diretamente a divulgação de informações. A prensa de Guttemberg gerou tantas possibilidades de difusão, propagação e fixação de conhecimentos que mais de cinco séculos depois, seus efeitos ainda são estudados. Da mesma forma, aconteceu com o invento do telefone, do rádio e da televisão.

Os estudiosos da Comunicação ainda se debruçam sobre todas as complexidades da televisão. Desde a Escola de Frankfurt, passando por McLuhan até Bourdieu, muito se publica da influência das imagens no cotidiano das pessoas.

A chegada da Internet como meio de comunicação trouxe também efeitos devastadores no fazer jornalístico e que ainda não foram profundamente estudados pela velocidade em que acontecem. No Brasil, a Internet deu os primeiros passos em 1995. Menos de seis anos depois os jornalistas já enfrentavam as primeiras crises decorrentes das grandes demissões, conseqüência do processo de endividamento das empresas de Internet, que não suportaram os grandes salários pagos aos primeiros jornalistas contratados para trabalhar nesse novo meio. 
De fato, o primeiro efeito da Internet foi o encantamento. A possibilidade de comunicação quase instantânea e de acesso a arquivos digitalizados de museus, bibliotecas universitárias européias e norte-americanas trouxe a sensação de que os chamados primeiro e Terceiro Mundos estava mais próximos, "ao alcance de um clique" era o bordão da época.

O avanço da Internet foi extraordinário. Em pouco tempo as "páginas-web" como são conhecidas deixaram de apresentar apenas textos ou figuras digitalizadas e passaram a comportar sons, imagens em movimento e vídeos digitalizados. As conexões aos servidores foram se acelerando e a quantidade de informações recebidas e enviadas era cada vez maior.

No jornalismo, esse incremento tecnológico provocou uma mudança nas mídias jornalísticas. Antes da Internet existiam o jornalismo impresso, o rádio-jornalismo e o telejornalismo. Jornalistas e receptores estavam "adaptados" a um esquema de como eram as notícias em cada mídia.

Para ilustrar, vamos tomar como exemplo algo simples e rotineiro como um acidente numa avenida expressa de uma grande cidade. O rádio era o veículo mais ágil e por isso era o responsável pelas notícias mais quentes. O repórter na viatura era o responsável por alertar aos motoristas do acontecimento do acidente. Como ele acabara de ocorrer o repórter não tinha muitos recursos a não ser pedir que os ouvintes evitem região. O repórter encerra a matéria - que dura menos de um minuto - prometendo voltar com outras informações.

A TV, pela grande quantidade de equipamentos (câmera, iluminação, baterias, fitas, tripé) e de profissionais, se desloca mais lentamente. Para compensar esse "atraso" ela vai fornecer ao telespectador as imagens do acidente - vamos supor que foi um caminhão que tombou, se incendiou e afetou as estruturas de uma ponte. Uma imagem área feita com o equipamento no helicóptero mostra a fila de carros parados no trânsito. Nos telejornais haverá as declarações de engenheiros de trânsito, de motoristas irritados e de alguma autoridade responsável ou pelo reparo dos danos ou pelo próprio acidente. 
No dia seguinte, o o acidente vai repercutir ainda mais no jornal, que vai publicar um mapa com alternativas de trânsito e detalhes apurados sobre as razões e conseqüências do fato, como o tempo de duração das obras de restauro da ponte danificada. Tudo num português claro e sem erros de concordância, acentuação e ortografia, pois se passaram horas da cobertura, tempo suficiente para a apuração.

Com a capacidade atual da Internet, não só de armazenamento de informações (diversos recursos gráficos, capacidade de reunir os diversos meios como escrito, gráfico, televisual e audiovisual) como de conexão (já que os usuários, nos locais de trabalho têm acesso 24 horas à Internet), as notícias sobre o acidente podem conter todas informações acima numa única página.

Se, por exemplo, um corretor de seguros precisa visitar um cliente e tiver de passar pela via onde aconteceu o acidente, ele vai consultar uma página que lhe informe o trânsito da região. Ele quer saber o que aconteceu, quais são as rotas alternativas, de preferência ilustradas por um mapa digitalizado, e quanto tempo vai demorar para se resolver o assunto. Se o site considerar adequado, vai colocar a imagem do caminhão incendiado, pode produzir uma simulação - usando o software flash - de como ocorreu o incêndio e até mesmo disponibilizar a fala do engenheiro de trânsito.

O leitor/internauta vai passar a exigir essas informações na medida em que elas se tornem prática de algum site. E também vai exigir o mesmo grau de apuração e esmero na redação de um jornal. O que era capricho de algum site vira exigência. Portanto, o jornalismo na Internet precisa ter a agilidade do rádio, a apuração e capricho do jornal e a quantidade de informações visuais da TV. A agilidade deve ser tanta que a notícia é considerada "informação em tempo real", como se tal expressão realmente pudesse existir. Há uma necessidade de cobertura imediata dos fatos, em "tempo real", levando ao receptor o acontecimento praticamente na mesma hora em que acontece.

Assim, a informação que chega ao receptor ou é transformada por uma série de profissionais explorados ao máximo em horas de trabalho ou é transmitida diretamente do local onde o fato se opera, sem qualquer espécie de filtro. "A mídia", analisa Ramonet, 
"sacrificando-se à ideologia do direto, do ao vivo, reduz o tempo da análise e da reflexão. $\mathrm{O}$ jornalista abandona as exigências da profissão, torna-se uma testemunha a mais". Se antes os eventos eram analisados, discutidos, debatidos, estudados, verificados e filtrados pelo jornalista antes de transmiti-lo ao cidadão, agora não há mais filtro ou crivo algum, apenas um "vidro transparente" na visão de Ramonet que afirma que "a função do jornalista desapareceu". No Brasil, casos como o seqüestro da filha do apresentador Sílvio Santos, o assassinato do prefeito Celso Daniel e o ataque aos EUA foram exemplos de transmissões instantâneas em que várias hipóteses eram jogadas ao público sem reflexão do que se falava. Os jornalistas que faziam as coberturas agiam e raciocinavam da mesma maneira que o público. Para Ramonet, está é uma necessidade de todos os meios de comunicação: "procurar colocar o cidadão diretamente em contato com o acontecimento".

A primeira reação a esse tipo de cobertura foi a alta remuneração. Os jornalistas foram contratados a peso de ouro (alguns profissionais recebiam, em 1999, até $\mathrm{R} \$ 10$ mil quando o piso da categoria não chegava a $\mathrm{R} \$ 1,8 \mathrm{mil})$. O financiamento para esses salários exorbitantes viria da publicidade na Internet. Os publicitários argumentavam que os anúncios feitos em pop-ups (janelas que se abrem na página) ou banners eram mais rentáveis, pois se poderia controlar quem, efetivamente, clicava nestes anúncios. Isto justificaria os altos preços destes anúncios. Porém, com o tempo, o mecanismo não se revelou tão preciso e os anunciantes passaram a desconfiar do retorno dos investimentos. A publicidade na Internet caiu rapidamente.

A queda da publicidade, no entanto, não acompanhou o ritmo quase alucinante da multiplicação de sites. A concorrência, que já é grande nos outros veículos, fica ainda mais acirrada na Internet. Alguns provedores passaram a fornecer o acesso gratuito à Internet, forçando os provedores pagos a incrementar os serviços com informações de toda a sorte. Os pequenos sites foram incorporados pelos grandes. Dessas incorporações surgiram os portais em que há de tudo: desde sexo até dicas de Língua Portuguesa. A concorrência pelo fornecimento de informações chega a registrar com quantos minutos de antecedência um 
portal divulga uma informação antes do outro. Por isso, as matérias na Internet são publicadas com o horário no cabeçalho.

Tamanha concorrência, além de não ter uma publicidade que a sustente, também não encontrou tanto público. A Internet ainda é cara para os padrões de renda brasileiros. 0 acesso 24 horas acontece com mais freqüência nos locais de trabalho. A porcentagem de brasileiros com acesso à rede de computadores não chegam a $20 \%$ e o número cai para os que têm acesso de casa.

As conseqüências, já sentidas nos primeiros anos do século XXI, portanto, seis anos depois da implantação da Internet no Brasil, foi a demissão e aumento da pressão sobre os jornalistas que restaram, num movimento oposto ao de 1999. O jornalista foi transformado num supercomunicador: repórter que apura antes dos outros, redator que não comete erros, editor que conhece linguagem html e publicitário que consegue patrocínio para o veículo de comunicação.

Este supercomunicador dedica seu tempo na busca de patrocínios, no aprendizado tecnológico e na tentativa de "furar" a concorrência. Não tem, evidentemente, tempo para se preparar intelectualmente. O resultado é, mais uma vez, a banalização do jornalismo. Para a América Latina resta a solidão.

O outro lado do crescimento da Internet como fonte de notícia é que, na chamada "sociedade da informação" na qual tudo e todos comunicam, qualquer pessoa pode se considerar jornalista, bastando criar um "site" na Internet. Eliminaria-se o filtro do jornalista quando algum elemento da sociedade cria seu próprio site e passa a divulgar notícias.

De início pode-se pensar que este processo democratiza as informações, já que os setores que se sentem marginalizados pela grande imprensa podem ser contemplados ao criar seus sites. De fato, essa possibilidade existe e a criação de sites de ONGs e movimentos sociais, como o dos zapatistas e do MST, é prova de que é um caminho que pode ser seguido.

Há, porém, pontos que ainda precisam ser estudados. Um deles é a confiabilidade que os receptores depositam nestes sites. Muitas vezes, quem os escreve é um jornalista ou 
alguém com tal função. A credibilidade é afetada porque o jornalista, quando empregado em algum veículo de comunicação, tem mais legitimidade (imposta pelo próprio receptor) do que quando a serviço de alguma empresa que não seja de comunicação. Fica muito difícil explicar ao receptor que, mesmo empregado num veículo de comunicação no formato tradicional, o jornalista também está refém de determinadas regras que fariam desacreditar seu trabalho em empresas de outro formato.

O outro ponto é, ainda, o pouco alcance da Internet no Brasil. Em 2000 o redator dessa dissertação uma pesquisa que apontava para a Internet como solução para acabar com o isolamento da América Latina no noticiário ${ }^{179}$. A pesquisa foi realizada durante o impacto da Internet e da contratação a peso de ouro dos jornalistas. Quatro anos depois, os números oficiais ainda não permitem que a Internet seja a salvação da América Latina.

O jornalista é um trabalhador que vende sua força de trabalho e, como tal, também é explorado, obrigado a cobrir muitas pautas num prazo muito curto, sem o tempo e espaço para a devida reflexão e análise. Ele disputa espaço com os anúncios publicitários, fisicamente e epistemologicamente. A notícia que ele "produz" deve gerar audiência, pontos necessários para o meio de comunicação conseguir mais anunciantes.

O cotidiano do trabalhador jornalista é feito não só da relação capital-trabalho, com todas as conseqüências que uma relação deste tipo implica, mas também é feito de uma busca constante pelo que gera audiência.

Na "máquina de moer carne" do jornalismo o tempo de reflexão é substituído pela disputa da pauta. Na sala de espera da coletiva se acotovelam colegas dos diferentes veículos de comunicação. Cinco colegas de emissoras de rádio, três de jornais diários, três de revistas semanais, três de televisão. Os assessores de imprensa tentam controlar, passam releases com o texto a ser publicado. As perguntas da coletiva se repetem. Não há mais o que falar? Se o profissional não está num bom dia, a solução é copiar o release.

${ }^{179}$ BARBOSA, Alexandre. A Luta de Classes entre a mídia oficial e a alternativa na América Latina: buscando fissuras nos muros do pensamento único. Tese de Conclusão de Curso de PósGraduação Lato Sensu em Jornalismo Internacional. São Paulo: PUC, 2000. 
No final do dia, cinco pautas depois, faltando minutos para o fechamento, os espaços em branco da matéria são preenchidos com trechos do release, com um rápido telefonema para o assessor de imprensa ou com uma consulta ao Guia de Fontes ou ao manual de redação. As preocupações com a estética e com as regras dos manuais de redação ocupam o espaço da criatividade. O medo de a concorrência publicar algo que você não conseguiu elimina a possibilidade de buscar uma nova visão sobre determinado assunto.

Na redação da Folha de S.Paulo há painéis luminosos sobre cada editoria. Nesses painéis, todos podem ler quantos erros aquela editoria cometeu na edição passada. Erros que podem ser de apuração da notícia, de Língua Portuguesa ou de descumprimento das normas do Manual. A solidariedade que deveria ser a tônica de qualquer classe trabalhadora, dá lugar a uma disputa de quem erra menos, de quem tira a maior nota, de quem não mancha a "reputação" do veículo. 


\section{Agências de Notícias e o trabalho do jornalista da Editoria de Internacional}

Y arriba quemando el sol

(Violeta Parra)

Cuando vide los mineros dentro de su habitación me dije: mejor habita en su concha el caracol, o a la sombra de las leyes

el refinado ladrón,

y arriba quemando el sol. Las hileras de casuchas, frente a frente, si, señor, las hileras de mujeres frente al único pilón, cada una con su balde y su cara de aflicción, y arriba quemando el sol.

Fuimos a la pulpería para comprar la ración, veinte artículos no cuentan

la rebaja de rigor,

con la canasta vacía volvimos a la pensión, y arriba quemando el sol.

Zona seca de la pampa escrito en un cartelón, sin embargo, van y vienen

las botellas de licor, claro que no son del pobre, contrabando o qué sé yo, y arriba quemando el sol. Paso por un pueblo muerto se me nubla el corazón, aunque donde habita gente la muerte es mucho peor, enterraron la justicia, enterraron la razón, y arriba quemando el sol. Si alguien dice que yo sueño cuentos de ponderación, digo que esto pasa en Chuqui pero en Santa Juana es peor, el minero ya no sabe lo que vale su sudor, y arriba quemando el sol. Me Volví Para Santiago Sin Comprender El Color Con Que Pintan La Noticia Cuando El Pobre Dice No, Abajo, La Noche Oscura, Oro, Salitre Y Carbón, Y Arriba Quemando El Sol. 
Quando se faz um trabalho histórico, a primeira tarefa é duvidar das informações oficiais. As gerações alfabetizadas ainda durante a ditadura militar utilizavam cartilhas que romanceavam os fatos de acordo com os interesses do grupo dominante à época. Duque de Caxias, o patrono do Exército brasileiro, não era visto como um assassino do povo paraguaio, mas como um grande líder brasileiro. ${ }^{180}$

Essas mesmas gerações, quando se deparam com um historiador que utiliza outra metodologia para estudar história, como é o caso de Maria Helena Valente Senise - que adota a metodologia da História Oral -, chocam-se. É como se descobrissem que existiu uma outra história, como de fato exisitiu. ${ }^{181}$ Há a história dos vencedores e a história dos vencidos. A dificuldade de se estudar com outras metodologias é que a história dos vencedores foi a que se propagou na historiografia oficial.

Da mesma forma funciona o jornalismo internacional, principalmente na grande imprensa. O jornalista que cobre internacional é alimentado pela versão dos vencedores.

Nas palavras de João Batista Natali, repórter da Secretaria de Redação da Folha de S.Paulo, que trabalhou 5 anos como redator da editoria de Internacional, depois 8 anos como correspondente em Paris e mais dois anos como editor de Internacional, "O redator de política internacional é um jornalista que tem pouco acesso às fontes que estão na origem da informação publicada. Há a intermediação das agências, dos comentaristas estrangeiros de cujas colunas o jornal é assinante, dos serviços que fornecem fotografias e infográficos." 182

A dependência das agências de notícias é comum tanto nos veículos que conseguem manter correspondentes - caso raro na imprensa latino-americana - quanto nos que não tem capital para tanto - o que é mais comum. Endividada, a imprensa brasileira só envia um correspondente em casos muito específicos: guerras de grandes proporções em países centrais, morte de alguma personalidade de impacto (como o Papa) ou um atentado ${ }^{180}$ CHIAVENATO, Júlio José. As lutas do povo brasileiro. São Paulo, Moderna, $15^{a}$ edição, 1996 ${ }^{181}$ ARBEX JR, José \& SENISE, Maria Helena Valente. Cinco Séculos de Brasil, Imagens e Visões. São Paulo, Editora Moderna, 1998.

${ }_{182}$ NATALI, João Batista. Jornalismo Internacional. São Paulo: Ed. Contexto, 2004. p 
de grande repercussão (como foram o de 11 de setembro, nos EUA, e o de 11 de março, em Madrid). Mesmo com o envio de correspondentes, é comum a utilização do material das agências, seja para ilustrar a matéria, seja para complementar a informação.

Margarethe Born ${ }^{183}$ relata que, durante a experiência de correspondente da Folha de S.Paulo em Berlim, tentou produzir notícias sobre a Guerra dos Bálcãs de acordo com os óculos dela, ou seja, os de mulher latino-americana. A jornalista foi repreendida pela direção do jornal que a mandou de volta para Berlim para cobrir a guerra de acordo com os despachos das agências internacionais.

As principais agências internacionais de informação são as norte-americana Associated Press (AP), United Press Internacional (UPI), a francesa Agénce France Presse (AFP) e a britância Reuters. Em menor escala estão a espanhola EFE e a italiana Ansa. Para Natali, a formação das agências internacionais no século XIX, está ligada à "vitória" dos países na expansão capitalista.

"Na história do jornalismo, a ascensão da bandeira de determinada agência esteve estreitamente atrelada à bandeira do país em que ela instalou sua sede e no qual fincou seus interesses. A França, o Reino Unido e os Estados Unidos foram países em ascensão no momento em que a industrialização os projetava por suas ambições expansionistas e por seu poderio industrial e mercantil. E, também, pelo poderio de sua imprensa. Em outras palavras, a história do jornalismo internacional é de algum modo a história dos vencedores. Os perdedores têm uma imagem bastante brumosa do passado de seu próprio jornalismo." 184

De fato, as agências internacionais surgiram no século XIX, logo após a segunda revolução industrial e com o objetivo de aumentar o lucro dos veículos de comunicação. Um dos primeiros fatos históricos a ser coberto por uma espécie de embrião das agências de notícias foi a Guerra Civil norte-americana (1861-65). A idéia era que um grupo de repórteres, ou mesmo um só, enviasse as notícias para muitos órgãos de imprensa.

A primeira agência de notícias surgiu em 1835, na França, fundada por Charles Havas. A Agência Havas deu origem à AFP e um de seus funcionários, o alemão Paul Julius Reuters, fundou a agência Reuters em 1851, em Londres. Nos Estados Unidos, em 1848, uma associação de repórteres para cobrir a guerra contra o México deu origem à Associated

${ }^{183}$ BORN, Margarethe Steinberger-Elias. Discursos Geopolíticos da Mídia. Op. Cit.

${ }^{184}$ NATALI, João Batista. Op. Cit. p. 32. 
Press. O objetivo era produzir mais informações a um preço menor. E essa é uma das razões que levam a grande imprensa se utilizar das agências até hoje.

Essa economia para produzir o noticiário internacional interfere diretamente em sua "geopolítica". Utilizar material de agências internacionais sediadas nos países centrais do capitalismo é reproduzir a história dos vencedores, é utilizar como óculos para enxergar o mundo os mesmos óculos dos países do centro do capital.

Natali chama de "apartidarismo" essa homogeneização de visões do centro e da periferia de capitalismo. "É uma postura de mercado. Como há clientes de diferentes orientações editoriais, nenhuma agência puxaria a azeitona para o lado de uma só empada. Se assim o fizesse, criaria melindres e perderia o freguês para uma agência concorrente"185 É ingenuidade de um jornalista tão experiente na área internacional acreditar que as agências internacionais, sediadas em países diretamente interessados em resoluções de conflitos, na ascensão ou na queda de governos, nos caminhos tomados por regiões do planeta, não partidarizem as informações.

Como foi amplamente visto nos tópicos anteriores, os órgãos de imprensa são aparelhos ideológicos. No caso da agências, por mais que elas se proclamem independentes de governo, não é possível abstrair o olhar europeu ou norte-americano na cobertura de um fato. As guerras no Golfo Pérsico, nos Bálcãs e no Afeganistão são exemplos de como só um lado do conflito tem seus interesses retratados.

${ }^{185}$ Idem. Op. Cit. p. 31. 
Além de receberem matéria prima enviesada, as editorias de internacional da grande imprensa operam um processo de seleção e corte de material maior do que as demais editorias. Não se pode reclamar da exigüidade de material. No livro Jornalismo Internacional, Natali escolhe, aleatoriamente, um dia para verificar a seleção de notícias pelos jornais da grande imprensa. O autor verifica que 1.400 textos de agências foram despachados e desses, de 10 a 18 se tornaram notícia, numa média de a cada 70 despachos apenas um ser aproveitado.

Na televisão, no entanto, há o fator imagem. Vicente Adorno, editor de Internacional da TV Cultura, diz, em entrevista, que a dificuldade em se falar da América Latina e de outras periferias deve-se ao fato que não são geradas imagens dessas regiões. Portanto, muitas vezes as notas que vão ao ar são o que se pode aproveitar do material recebido. Isto apenas reforça o fato de que as agências geram notícias apenas das regiões próximas ou de interesse de seus países-sede, relegando às periferias a cobertura apenas em épocas de conflitos ou desastres.

Natali afirma que a escolha é feita por critérios refinados e qualificados e que não há censura dos jornalistas. Porém, pelo trecho selecionado abaixo, percebe-se como o jornalista utiliza óculos determinados para selecionar o que é importante ou o que é banal.

"A seletividade implica hierarquizar para escolher, deletar ou jogar no cesto de lixo eletrônico coisas que sejam circunstancialmente menos importantes. Ninguém estará 'censurando' caso deixe de publicar uma declaração do presidente do Egito sobre a importância cultural do islamismo [...] se eu deixasse de lado um telegrama com a entrevista que o embaixador da Colômbia na Venezuela na qual abordou problemas bilaterais que pouco interessam ao Brasil. Seria também o caso de um discurso do ditador Fidel Castro, caso ele aborde pela $347^{\mathrm{a}}$ vez determinado tema que faz parte da agenda oficial cubana. Até declarações de um personagem em geral tão importante, como o presidente dos Estados Unidos, podem ir tranqüilamente para o lixo."186

${ }^{186}$ Idem. Op. Cit. p. 11. 
Egito, Cuba, Colômbia e Venezuela são debochados. Os EUA são importantes, mas também podem ir para o lixo, sem provocar no redator de Internacional maiores remorsos. O próprio Natali reconhece que há "desconhecimento voluntário ou involuntário de tragédias humanitárias" de determinadas regiões do planeta.

\begin{abstract}
"Uma ONG chamada Médicos Sem Fronteiras divulgou, no começo de 2004, uma relação de dez grandes tragédias humanitárias que a mídia americana cobriu muito mal ou praticamente ignorou. Havia os refugiados na fronteira entre o Chade e o Sudão, os conflitos na Tchetchênia, na Colômbia e no Burundi, a guerra civil no Congo e na Costa do Marfim. [...] Dos 14.635 minutos do noticiário monitorados em 2003, só 30,2 minutos - ou $0,2 \%$ daquilo que foi levado ao ar - foram dedicados às tragédias humanitárias que a MSF destacou." 187
\end{abstract}

Apesar de ser complacente com a guilhotina dos jornalistas de internacional, Natali vê, nas novas gerações, cada vez menos engajamento político. Engajamento que, de acordo com o autor, permitiu, mesmo sob a censura da ditadura militar, a cobertura de eventos como as ações dos Tupamaros no Uruguai, a vitória de Salvador Allende e o golpe que o derrubou e a derrota norte-americana no Vietnã.

O mesmo fenômeno foi apontado por José Arbex Jr., no livro Showrnalismo ao criticar a despolitização empregada pela Folha de S.Paulo e que provocou queda acentuada da qualidade do noticiário. Para Natali: "o engajamento em nossas vidas pessoais era uma forma de conhecimento do mundo [...] Pois algo de muito curioso aconteceu a partir dos anos 80. O engajamento político saiu de moda. Uma das conseqüências do desengajamento foi o esfriamento da relação do jornalista com o mapamúndi”. 188

Esse desengajamento, que distancia o jornalista de se interessar por regiões do planeta em que se operam conflitos, em que há "inimigos" para vigiar e "aliados" por quem torcer é conseqüência, entre outros fatores, da despolitização empregada pela ditadura militar na vida cotidiana brasileira e pelo esvaziamento político-social dos currículos de ensino médio e superior.

\footnotetext{
${ }^{187}$ Idem. Op. Cit. p. 13.

${ }^{188}$ Idem. Op. Cit. p. 70-1.
} 


\section{Formação acadêmica dos jornalistas}

Para a América Latina, é dever do jornalista conhecer a História e a realidade político-social-econômica dos demais países. Durante os jogos pan-americanos de 2003 em Santo Domingo, na República Dominicana, um repórter da Rádio Bandeirantes, ao entrar ao vivo em um dos primeiros boletins feitos na sede dos jogos se surpreendeu ao constatar que a cidade é a mais antiga das Américas. O repórter anunciava, com certa surpresa na fala, que estava diante de uma das mais importantes e antigas catedrais, marco da colonização cristã no chamado Novo Mundo.

A América Latina é uma grande incógnita. Nomes como Mella, Miguél Mármol, Rivera, Recabarrén, Mariátegui, Martí, entre outros são desconhecidos e só aparecem nos jornais quando o México ou a Argentina produz filmes sobre determinado personagem - e quando esses filmes são premiados - ou quando alguma organização guerrilheira adota alguns destes nomes (como o Tupac Amaru, no Peru), faz um atentado e é preciso ir correndo explicar ao público com o que Emir Sader chama de "argumentos de algibeira": enciclopédias, sites na Internet ou entrevistas-relâmpago com algum especialista em América Latina.

Parte deste desconhecimento é acadêmico. Não se ensina América Latina nas escolas, nem no Ensino Médio e nem no Ensino Superior, a não ser que se faça um curso específico no assunto. Mesmo assim, é difícil encontrar uma pós-graduação dedicada ao tema de forma integral. Aprende-se América Latina apenas o que seria necessário para entender História do Brasil: colonização, povos pré-colombianos e as guerras platinas.

As Universidades e os institutos de pesquisas acadêmicas não estabelecem parcerias com universidades latino-americanas. Há poucas linhas de pesquisa sobre a América Latina popular nas Universidades. O que é feito e produzido ainda não é o suficiente para produzir gerações de intelectuais orgânicos da América Latina, muito menos jornalistas orgânicos da América Latina.

Nas escolas de educação básica no Brasil, o ensino público foi degradado por anos de descaso dos governos e por uma campanha de despolitização dos currículos escolares 
feita ainda durante o regime militar. Foram retiradas dos currículos disciplinas e conteúdos curriculares de debate e conscientização e no lugar foram introduzidas matérias com conteúdos fechados, pasteurizados. Os salários dos professores foram achatados, os investimentos diminuídos o que provocou a migração de professores para o ensino particular. As mudanças na Lei de Diretrizes e Bases e nos Parâmetros Curriculares Nacionais ainda são recentes para recuperar o estrago causado em gerações educadas com base na cartilha e na repetição. Nesse contexto, o estudo da história da América, fica restrito, quando muito, a uma "visita" longínqua às civilizações pré-colombianas e a um breve passar de olhos sobre os processos de independência, principalmente o norteamericano. Um estudante formado no terceiro ano de ensino médio conhece muito mais Lincon e Roosevelt do que Artigas e Tupac Amaru.

As poucas instituições superiores que se dedicam ao estudo da América Latina parecem fazer pregação no deserto. Esta dissertação enfrentou grandes dificuldades para encontrar linhas de pesquisa e bibliografias que não fossem aquelas usualmente estudadas. Independentemente do brilho, da qualidade, do pioneirismo e da importância dos trabalhos de José Marques de Melo e da Cátedra da Unesco, de Maria Nazareth Ferreira e do Celacs e de Cremilda Medina e do Prolam, é preciso afirmar que ainda é muito pouco para o maior país latino-americano.

Na bibliografia desta dissertação, o leitor poderá encontrar os autores tradicionais. Porém, há uma tentativa do pesquisador de buscar novas fontes, novas leituras, ou mesmo resgatar outras e traze-las para o contexto do Jornalismo na América Latina. Uma das hipóteses levantadas por este trabalho é que o enfraquecimento da América Latina popular também tem origem na pulverização dos conhecimentos. O acordo MEC-USAID, estabelecido durante a ditadura militar, fragmentou o currículo dos cursos superiores brasileiros e provocou enorme estrago, não recuperado até agora.

Quando o jornalista é chamado a cobrir algum evento num país latino-americano fica mais fácil copiar o material produzido pelas agências do que investigar com seus próprios 
conhecimentos, simplesmente porque ele não os tem. Não lhe foram ensinados e ele, jornalista, também não teve motivação para ir buscá-los.

Se na mídia já há um "deserto de informação sobre a vida nacional dos povos, em benefício da notícia que privilegia o jogo das potências políticas e econômicas [...] os países latino-americanos simplesmente não interessam. A 'globalização' apenas acentuou o quadro de distanciamento cultural, intelectual presentes entre a elite e a nação em toda a América Latina". ${ }^{189}$ Arbex confessou que uma das coisas que mais lhe abalaram durante o período quem foi correspondente internacional da Folha de S.Paulo foi "saber que certas notícias eram censuradas ou descartadas não por afetaram interesses políticos ou econômicos, mas simplesmente consideradas desinteressantes a priori, mesmo se fascinantes. Eram descartadas por um processo de pura exclusão cultural". ${ }^{190}$

O quadro para compreender a solidão da América Latina agora está mais completo. De um lado, está todo o ambiente sócio-histórico em que o jornalismo brasileiro atua: continente devastado por mais de quinhentos anos de repressão aos movimentos populares, o processo histórico de formação do Estado que alijou a participação popular de qualquer chance de manifestação, a americanização do Brasil coincidindo com o desenvolvimento da empresa jornalística, a não formação de intelectuais brasileiros orgânicos à América Latina - tudo isso tornando jornalistas e público, personagens "estranhos" ao continente. De outro lado, o próprio jornalismo, viciado na pauta consensual, nos assuntos ônibus, na circulação circular da informação, que também não se reconhece latino-americano. A tudo isso se soma a exploração do jornalista nas redações, a excessiva carga de trabalho, a ideologia do "ao-vivo", da notícia "em tempo real" que suprime o espaço para reflexão e apuração. O jornalista explorado também não reage, pois não teve formação intelectual suficiente. A grade curricular do Ensino Superior em Jornalismo apenas o prepara para ser um cumpridor de tarefas. Mais que a grade curricular, cabe ao professor a tarefa de preparar o profissional de jornalismo consciente, crítico, que saiba diferenciar as construções históricas dos vencidos e dos vencedores. O professor é a figura que motiva a ${ }^{189}$ ARBEX JR., José. Op. Cit.
${ }^{190}$ ARBEX JR., José. Op. Cit. 
turma. Ele é a referência. Mesmo diante de uma grade curricular quadrada, o professor consegue despertar emoções que incentivem os alunos a fugirem do pensamento único. Há diversos recursos pedagógicos que serão detalhados no próximo tópico.

\section{1 - Mudanças na grade curricular do Ensino Superior de Jornalismo: uma} proposta

Um professor de um curso superior em Jornalismo pode oferecer, por exemplo, um curso sobre a América Latina como recurso para a aprendizagem. O uso do tema "América Latina" traz significado para o estudante. A aprendizagem sem significado real soa para o estudante como sílabas sem sentido e, conseqüentemente mais árida de ser compreendida, analisada e sintetizada. A primeira tarefa é eliminar a simples exposição de datas e acontecimentos que terão, para o estudante, o mesmo efeito de aprender sílabas sem sentido. Rapidamente as datas serão esquecidas, além de parecer um conteúdo maçante e desconexo da vida acadêmica e profissional. A seleção do que vai ser estudado deve ser feita de acordo com as características dos estudantes e contextualizada com a carreira discente.

Para saber quais serão estas necessidades não é preciso usar bola de cristal. Basta deixar de lado o costume de usar o mesmo programa de aula para todas as turmas. Cada uma tem um perfil diferente. Por mais que a taxionomia dos objetivos cognitivos forneça um mapa de quais conhecimentos são dominados pelo aluno que chega ao nível superior, é fato de que cada instituição usou um método para transmitir esses conhecimentos e cada um os absorveu de uma forma. Também é preciso levar em consideração que as gerações sofrem profundas mudanças de influências e valores. A mesma aula não pode ser ministrada para uma turma que acompanhou o processo de esvaziamento da Guerra Fria e para outra que se formou depois do fim da bipolaridade.

Identificados os grupos e traçado o perfil da turma o professor deve partir para o problema real. Um recurso interessante e que vai promover empatia entre o facilitador e os estudantes durante os encontros, é selecionar um tema que esteja na pauta dos jornais. 
"Qual deve ser o professor responsável pela escolha deste tema?" é a primeira pergunta feita pelo educador.

Aqui surge a necessidade de um corpo docente sintonizado e de um projeto pedagógico bem definido e focado na resolução das questões latino-americanas (eliminação da pobreza, preservação da fauna, flora, folclore, recursos naturais e humanos). Não é possível construir um curso em que cada professor é o senhor feudal de sua cadeira, em que haja verdadeiros fossos entre as disciplinas e no meio deles, fiquem os estudantes, como servos presos pelas obrigações de vassalagem. Seria ideal que os professores, com o relatório do perfil em mãos, se sentassem para conversar e planejassem, no mínimo, o bimestre, com um tema que integre todas as cadeiras. No atual modelo educacional, conforme cresce a idade do estudante mais dificuldades são colocadas para promover a integração do conhecimento. As disciplinas vão se fechando em castelos desde o Ensino Fundamental até chegar à "feudal" divisão universitária.

Os professores do curso de Jornalismo podem decidir, por exemplo, que no bimestre o tema, recolhido das páginas dos jornais é a Área de Livre Comércio das Américas, a ALCA. Essa escolha, entretanto, não deve ser casual. Ela deve envolver a consciência de que estão todos inseridos num continente com características que merecem estudo e o desmonte de preconceitos - a América Latina. As conseqüências de um acordo como esse afetam diretamente a carreira e a vida de cada um dos estudantes e professores.

Cada professor terá, dentro de sua disciplina, como trabalhar este tema envolvendo o estudante e estabelecendo um contrato de aprendizagem, pois há um objetivo final e concreto: a criação e distribuição de um jornal sobre o assunto ALCA que na universidade.

Com esse contrato "assinado", o estudante pode vislumbrar uma carreira discente. Ele sabe que vai passar por fases dentro do curso e que, se cumprir o contrato estabelecido, vai ser "promovido" na carreira, passando do jornal interno ao jornal da comunidade, ao telejornal que é veiculado na TV a cabo e assim por diante. Então, ele terá condições de compreender que as disciplinas não estão ali simplesmente para preencher requisitos do MEC, mas para aumentar o seu "capital intelectual". 
Na disciplina de Metodologia de Pesquisa, o professor estabelece o quadro da pesquisa, mediante a colocação de problemas - por exemplo: busca de alternativas de aliança a outros blocos comerciais ou análise da cobertura da imprensa sobre o assunto dentro de um ambiente receptivo. Isso possibilita aos estudantes realizar descobertas autônomas e empenhar-se em uma aprendizagem autodirigida.

Ao final do curso, o que antes era tenebroso - o Trabalho de Conclusão de Curso (TCC) - será o apogeu de um trabalho empreendido pelo estudante desde os primeiros meses, quando já começa a recolher informações e monta um banco de dados que vai alimentar sua futura monografia.

Introdução ao Jornalismo vai sugerir a confecção e distribuição de um jornal que explique aos alunos, funcionários e professores o que é a ALCA, o que já foi discutido e quais as conseqüências da assinatura deste tratado no dia-a-dia de cada um. Ao mesmo tempo em que explica os principais pontos do jornalismo, o professor faz um alerta. Para que o jornal realmente cumpra seu propósito, o aluno deve se cercar de uma série de conhecimentos e teorias. O público-alvo é heterogêneo, os assuntos são áridos e exigem pesquisa, o projeto gráfico precisa ser interessante.

O estudante deve perceber que para o jornal ter sucesso ele necessita de conhecimentos que estão nas outras disciplinas. Na avaliação do resultado, deve ser "cobrado" do estudante a aplicação do que aprendeu e do que foi acordado no contrato de aprendizagem. O projeto prático se torna a verificação da teoria. Se o jornal não comunicou bem, é sinal de que houve falha no projeto gráfico, na seleção das notícias, no tratamento da matéria, na apuração dos fatos.

A disciplina de Artes Gráficas deve fornecer recursos que mostrem como comunicar a públicos distintos. Quais os tipos de fonte, como é a hierarquia das matérias na página, etc.

A regulamentação profissional do jornalista numa área de livre comércio é o assunto de Legislação. Entre as dúvidas que podem ser debatidas estão as documentações 
necessárias para um repórter brasileiro poder escrever em um jornal argentino e os países que exigem diploma para o exercício da profissão.

A análise das matérias vai mostrar que boa parte do conteúdo sobre América Latina tem origem no material das agências internacionais, tema de estudo para Sistemas de Informação. Além de a disciplina abordar os locais de produção da informação, é o primeiro passo para a montagem do banco de dados que vai ser útil primeiramente para a redação do jornal e mais tarde para os TCCs e a outras turmas que pesquisarem esse assunto. A responsabilidade de produzir um trabalho que servirá de recurso para futuros estudantes e faça parte do acervo da universidade reforça no estudante o compromisso em cumprir bem o contrato de aprendizagem e aumenta sua sensação de liberdade, pois o professor não vai precisar cobrar a manutenção desse arquivo - o próprio estudante o fará.

Em Economia o aluno pode aprender os principais conceitos relacionados ao tema selecionado: dólar, inflação, bolsa de valores, câmbio, grandezas matemáticas, entre outros. Esses conceitos serão importantes na discussão do significado da implantação da área de livre-comércio e para a redação de matérias claras e informativas no jornal interno.

As disciplinas de Filosofia e Sociologia também são muito importantes para os futuros repórteres se cercarem dos conceitos que envolvem o tema. Nelas, o estudante poderá compreender a resistência ou aderência de cada país à assinatura de acordo. Quais os princípios filosóficos que servem de lastro para os diferentes movimentos sociais organizados, como o MST no Brasil ou os Zapatistas no México.

Para que não haja confusão dos termos políticos, como eleições parlamentares, trâmites de votação nas câmaras altas e baixas, a disciplina de Política torna-se um verdadeiro manual de conceitos.

Atuando como suporte para entrevistas e para facilitar o melhor entendimento das reações do ser humano diante de determinadas situações, a Psicologia é outra das disciplinas que integram o curso.

Finalmente, a disciplina de História da América Latina é a responsável pela transformação das idéias em conceitos fundamentados. Como foi visto nessa dissertação, a 
preparação intelectual do jornalista, principalmente em História, é um diferencial de qualidade.

Para melhorar a dinâmica das disciplinas deste curso é importante que os professores usem o maior número possível de recursos acadêmicos - filmes, livros, artigos, músicas, peças de teatro, documentários, páginas da Internet, laboratórios, salas ambiente. Especificamente para o tema "América Latina", as aulas de História são incrementadas com músicas de Sílvio Rodrigues, Victor Jara e Violeta Parra que descrevem o cotidiano de camponeses pobres. Sobre o tema "México e Zapatismo", há um CD, gravado para angariar fundos para os moradores de Chiapas com músicas sobre a consciência dos indígenas. No campo de documentários e filmes merecem destaque 15 Filhos e Vala Comum sobre a Ditadura Militar brasileira, Amazônia em Chamas, sobre o Chico Mendes e Cuando Pienso em Che, sobre a Revolução Cubana.

Com o jornal em mãos, os estudantes podem discutir quais matérias tiveram mais impacto, quais foram mais difíceis de fazer, quais ficaram com falhas na informação, entre outras observações. A partir desse relato, todos os professores - não só aquele responsável pelo jornal - podem retomar conceitos. Exemplo. Uma reportagem muito confusa sobre as taxas de câmbio, por exemplo, serve para repassar os termos aprendidos em Economia. Um texto importante sobre as relações comerciais que, eventualmente, tenha ficado "escondido" na página é oportunidade para lembrar os conceitos de hierarquia da informação. Agindo desta forma, no decorrer do curso, o aluno vai compreender naturalmente disciplinas mais densas como Teoria da Comunicação e Sociologia da Comunicação, que podem ser deslocadas para os últimos meses dentro da grade curricular.

O resultado final pode não ser um jornal tão bonito e tão propício ao marketing como desejaria a direção ou a mantenedora. Alguns "erros" podem passar - entendendo o "erro" não como uma falha, mas como uma etapa do processo de aprendizagem. $E$ também pode servir para tirar das sombras o continente latino-americano. No entanto, para a real verificação dessa estratégia docente e dos resultados obtidos sobre a solidão da América 
Latina, é necessária a realização de um estudo mais aprofundado, que pode ser excelente matéria para um futuro doutorado.

\section{2 - A importância da disciplina História da Imprensa: caso dos estudantes do}

\section{Centro Universitário Nove de Julho}

É evidente que os resultados da alteração do currículo não podem ser avaliados a curto prazo e nem são imediatistas. É uma pesquisa de grande fôlego. Obviamente, também não se pode mensurar imediatamente o impacto destas alterações no isolamento da América Latina. O quadro de solidão é demasiado complexo e barreiras, como a herança colonial, não são transpostas com ações isoladas.

Entretanto, todo professor assume certa dose de sacerdócio na sua profissão. Sacerdócio não no sentido de dom ou de inspiração divina, mas na confiança de que realiza uma missão, de que carrega uma qualidade de pastor. Pastor que muitas vezes caminha no deserto, para usar uma visão bíblica, é verdade. Essa crença na missão sacerdotal associada à alegria de despertar corações e mentes com as descobertas proporcionadas pela aprendizagem é o que leva milhares de professores a enfrentar condições adversas.

Ensinar em barracões de madeira, utilizando a parede como lousa; dar aulas à noite quando estudantes e professores se esforçam para vencer o sono; ganhar salários baixos; lidar com a falta de material, com desvios nas políticas públicas, com turmas que enfrentam sérios problemas sociais (envolvimento com crime organizado, por exemplo) são situações vistas quase que diariamente pelos professores da América Latina.

Assim como há problemas, há também soluções. E há inúmeras soluções criativas. Professores que adaptam o currículo às características regionais e métodos pedagógicos que se aproveitam dos conhecimentos já adquiridos pelos estudantes em outros campos de atuação são exemplos de como a aprendizagem pode revolucionar, se não o mundo, pelo menos aquele microcosmo alcançado pelo professor. 
Em 2005, o autor desta dissertação recebeu a missão de ministrar a disciplina de História da Imprensa para a turma 1B3, do curso de Jornalismo da unidade Vila Maria do Centro Universitário Nove de Julho (Uninove), em São Paulo. A Uninove é uma instituição privada de ensino superior, dedicada às classes C e D da região metropolitana de São Paulo. Como toda instituição privada de ensino, consegue seu lucro por meio das mensalidades pagas pelos estudantes, vistos mais como clientes na aquisição de um produto do que como educandos. Quer dizer, se a relação entre professor e estudante corre com tranqüilidade, valem todos os conceitos pedagógicos. Nos momentos de conflito extremo, vale a relação mercadológica.

A Uninove tem, como público-alvo, estudantes egressos de escolas públicas. Destes, é considerável o número dos que concluíram o ensino médio há mais de três ou quatro anos e que primeiro foram conseguir renda trabalhando para depois cursar o ensino superior. A direção da Uninove, durante a palestra de integração, gosta de afirmar que os alunos são os primeiros da família a conseguir diploma de nível superior.

Neste quadro, encontram-se estudantes de diferentes níveis e experiências. Mas algumas características são comuns: são vítimas dos descontinuísmos das políticas públicas de educação. O conhecimento acumulado está fragmentado. Fazendo uma anologia com a escola do colonizado, descrita por Albert Memmi: "Ora, a maior parte das crianças colonizadas está na rua. E aquele tem a insigne oportunidade de ser acolhida em uma escola, não será por ela nacionalmente salva: a memória que lhe formam não é a de seu povo. A história que lhe ensinam não é a sua. “191

O programa de História da Imprensa, aprovado pelo Ministério da Educação, pede que se ensine a história dos veículos de acordo com suas características de emissão. Primeiro se ensina a história dos impressos, do Correio Braziliense à Folha de S.Paulo. Depois, a história do rádio, de Roquette Pinto à $C B N$, na seqüência a TV, de Assis Chateaubriand à TV Globo, por último, um histórico da Internet, da ARPAnet até os grande

\footnotetext{
${ }^{191}$ MEMMI, Albert. O Retrato do colonizado precedido pelo retrato do colonizador. $3^{\text {a }}$ ed. São Paulo: Ed. Paz e Terra, 1989.
} 
portais. Assim, fragmentada, a história da imprensa soa artificial para iniciantes no jornalismo, que carregam deficiências no conhecimento de história.

A invenção da imprensa por Gutemberg, no século XV não foi um ato de caridade, mas conseqüência de um processo de desenvolvimento capitalista, que exigia informações circulando de forma mais ágil. A invenção das comunicações por telégrafo, rádio, satélite e fibra óptica segue a mesma lógica. O encurtamento das distâncias comerciais obriga os meios de comunicação a se desenvolver mais rapidamente. E o jornalismo vai a reboque.

O programa ministrado para a turma 1B3 de Jornalismo não foi invertido, mas adaptado. Nenhum conteúdo deixou de ser ministrado. Porém, a forma como foi exposto levava em consideração a linha do tempo histórica e não a característica de veiculação. A cada unidade era associado o contexto histórico. Por exemplo, a implantação e a popularização do rádio nas décadas de 1920, 1930 e 1940 no Brasil foi contextualizada com a ascensão do governo Getúlio Vargas e o processo de sedução do Brasil pelos EUA para o país se aliar na luta contra o nazismo, assim como o surgimento da imprensa alternativa nos anos 60 e 70 foi contextualizado com o endurecimento da ditadura militar brasileira.

Como as aulas aconteciam em paralelo com a redação desta dissertação de mestrado, era inevitável o uso de exemplos relativos à América Latina. O primeiro trabalho pedido aos alunos foi a construção de uma linha do tempo.

De um lado da linha deviam ser descritos uma série de fatos históricos. Do outro, as datas de invenção da imprensa, do rádio, da TV e da Internet, bem como seus usos como meios de comunicação de massa. O objetivo era produzir manchetes dos fatos históricos de acordo com o veículo de comunicação que existisse na época. Por exemplo, a Revolução Cubana, de 1959 deveria ser retratada em manchetes para o impresso, para o rádio e para a TV. Para incluir a América Latina no cotidiano dos estudantes, entre os fatos históricos a serem manchetados estavam a independência das colônias americanas, a ditadura de Vargas, a Revolução Cubana e o golpe militar de 1964, além de outros eventos como a Guerra Civil Espanhola e a Guerra do Vietnã. 
O ponto mais debatido nessas aulas foi a questão dos tipos de história. A primeira aula tinha como epígrafe a frase do subcomandante Marcos "Porque morrer não dói. O que dói é o esquecimento". A intenção era mostrar que determinadas lutas, povos e regiões foram esquecidas por alguns livros de história. A cada encontro sempre foi reforçada a necessidade de se duvidar das fontes históricas, de não acreditar no primeiro livro de história, de sempre buscar outras fontes, de cruzar dados.

Vários exemplos históricos, como Canudos e as lutas de resistência à ditadura, foram utilizados para mostrar a importância de se saber também a história dos vencidos. Foi quando ganhou importância a imprensa alternativa, a responsável, como afirma Maria Nazareth Ferreira, por registrar a história das classes subalternas. Se não fosse pela imprensa alternativa, hoje não seria possível conhecer a fundo a história das primeiras greves operárias, da perseguição aos comunistas e das guerrilhas urbanas.

Na fase dos seminários, um grupo ficou encarregado de conhecer os atuais veículos da imprensa alternativa: Caros Amigos, Brasil de Fato e Agência Carta Maior. O resultado foi excelente. Os alunos que visitaram a redação da revista Caros Amigos ficaram encantados. Enquanto os demais grupos tiveram muitas dificuldades para ser recebidos pelos veículos da grande imprensa - cada apresentação era um "muro de lamentações" da falta de atenção -, o grupo da imprensa alternativa trouxe grande quantidade de material, até além do que foi pedido para pesquisa. Tanto que o grupo que fez o trabalho decidiu criar o seu próprio veículo alternativo, para divulgar notícias do que, em sua opinião, os jovens da periferia da América Latina gostariam de saber mas não encontram na grande imprensa.

Uma das integrantes, Nathalia Ferreira de Campos, declarou que foi uma descoberta em sua vida. "Nossos professores no Ensino Médio deveriam nos mostrar esses dois lados. Eu nunca soube que existia uma outra história, que não se podia acreditar cegamente nos livros. Também não sabia que existia uma revista como a Caros Amigos. Para mim, tudo que saía na Folha de S.Paulo era verdade. Agora sei que existe um outro lado". 192

\footnotetext{
${ }_{192}$ Depoimento de Nathália Ferreira de Campos, estudante do primeiro ano de Jornalismo do Centro Universitário Nove de Julho, ao autor desta dissertação em 25 de maio de 2005.
} 


\section{CONSIDERAÇÕES FINAIS}

América novia mía

(Patricio Manns)

Morena América mía litoral el viento peina tu pelo de cristal, tu pecho de tierra oscura mineral modula en el canto de oro del trigal. América novia mía este cantar despierta el canto del pueblo en voz de mar, la libertad ha salido a navegar, es hora de combatir y caminar. América novia mía tómame, entre tus brazos mulatos cíneme, en la boca tus dulzores viérteme, y el pecho de resplandores lléname. Morena América mía, la traición, la hiedra del mal saltó a tu corazón, la sangre cubrió de flores el cañón, la selva vuelve a latir en la canción. América novia mía con afán tus hijos vino de caña te darán amargo pero tan nuestro ya verás, tan nuestro que será dulce sentirás.

Morena América mía no hay dolor al cual el hombre no aplaste triunfador.

Es duro el camino del libertador, es largo el regreso del conquistador.

No cancioneiro do grupo chileno Quillapayún há um disco de 1970 chamado Cantata Santa Maria de lquique., que traz 18 músicas que contam a história do massacre da Escola de Santa Maria de Iquique, em 1907. Nesse massacre 3.600 operários salitreiros chilenos foram assassinados como resposta dos "negociadores" diante da greve de uma das indústrias mais importantes do país, na época já controlada por norte-americanos.

Uma das formas de lembrar o triste acontecimento foi retratar o massacre, o que foi feito por Gabriel García Márquez, na fictícia Macondo de Cem Anos de Solidão, em que mais de 3 mil trabalhadores morreram ao negociar a greve na Companhia Bananeira, também controlada por norte-americanos. No romance, o episódio foi escondido de todos. Os corpos foram jogados nos vagões de um trem e nunca mais apareceram. Ninguém acreditou no depoimento do único sobrevivente e foi como se o massacre não tivesse 
acontecido. Da mesma forma, o assassinato dos grevistas chilenos não consta dos principais conteúdos escolares, apesar de sua importância e relevância.

O sociólogo Emir Sader aponta o episódio de 1907 como o primeiro de uma série de acontecimentos que fizeram o mundo conhecer a América Latina. Na seqüência vieram a Revolução Mexicana, a Reforma Universitária de Córdoba, a Revolução Cubana, além do reconhecimento internacional da literatura com os prêmios Nobel de Gabriela Mistral e mais tarde de Miguel Angel Astúrias, Pablo Neruda e de Gabriel García Márquez.

Destes importantes fatos, muitos continuam "empoeirados", esquecidos pela Academia e, sobretudo, pela mídia. A não ser pelas ações de intelectuais ou militantes ligados à América Latina, o massacre seria abandonado nos baús históricos. A primeira canção de Cantata Santa Maria de Iquique se inicia com o verso: "Señoras y Señores venimos a contar / aquello que la historia/ no quiere recordar". Os registros do massacre estão nas páginas da imprensa proletária, na linha do tempo construída por partidos de esquerda e nos textos de intelectuais e militantes de esquerda.

No percurso acadêmico que levou à redação desta dissertação de mestrado, o ponto que mais provocou reflexão e debate foi a descoberta de que há dois tipos de construção histórica. Vencedores e vencidos, classes dominantes e subalternas constroem duas histórias. O massacre de lquique - entre outros - é lembrado como um fato importante pelos movimentos sociais latino-americanos, enquanto os livros da historiografia oficial preferem dar destaque aos ambientes palacianos, aos pactos de elite que dominaram a história do continente por mais de 500 anos.

Se a história opera duas construções diferentes, de acordo com os interesses das classes envolvidas, o jornalismo é o meio em que essa prática é ainda maior. A imprensa, por excelência, seleciona e exclui fatos no processo de transformação de acontecimentos em notícia. Que este processo exclui a América Latina, diversos trabalhos anteriores a este demonstraram fartamente.

A pergunta que esta pesquisa queria responder era quais fatores contribuíam para formar o quadro de solidão da América Latina no jornalismo brasileiro. A hipótese levantada 
é de que não se pode procurar a resposta em apenas um campo de ação: a solidão da América Latina na mídia não é resultado apenas da lógica do Jornalismo. Para entender os fatores que levam uma região do globo, com toda sua história, sua cultura e todos os acontecimentos - como os citados - a desaparecer de jornais, rádios, TVs e sites é preciso desvendar um cenário baseado em dois eixos.

No eixo 1, batizado de ambiente sócio-histórico, estão os fatores ligados à História, à americanização, ao preconceito, à influência da ideologia capitalista e à cisão do continente em duas Américas Latinas: a América Latina Popular e a América Latina Oficial. No Eixo 2, dedicado ao jornalismo, estão os fatores que explicam o modo de produção jornalístico: a pauta consensual que faz circular as notícias dentro de um círculo restrito do que deve ser noticiado, as relações de trabalho nas redações, a formação intelectual dos jornalistas e o caráter capitalista da mídia, que é um aparelho ideológico da América Latina Oficial.

O processo colonial - e neocolonial - fabricou duas Américas Latinas, tão bem descritas por Frantz Fanon na obra Os Condenados da Terra. São duas regiões excludentes: uma é iluminada pelo capitalismo outra é esquecida por ele. A América Latina Oficial é a América Latina branca e burguesa, herdeira direta dos privilégios do colonizador e associada ao capital estrangeiro, como forma de manter seus privilégios. Na América Latina oficial estão as ruas de São Paulo, a Ipanema do Rio de Janeiro, Recoleta e Palermo de Buenos Aires, Las Condes de Santiago de Chile. E todas as capitais e cidades litorâneas, de olhos voltados para a Europa e os EUA.

A América Latina Popular é mestiça, negra e índia. É operária e camponesa. Seus moradores são herdeiros dos colonizados e até hoje só conhecem a venda de sua força de trabalho como forma de sobrevivência. Quando há para quem vendê-la. Do contrário são condenados à periferia das periferias, alimentando as fileiras dos movimentos sociais ou engrossando a população dos presídios construídos pela América Latina burguesa. Na América Latina popular estão as cidades e rincões do interior, os países desconhecidos pela mídia e as periferias das grandes metrópoles. 
Cada América Latina tem a sua imprensa. A grande imprensa - os jornais tradicionais, as revistas, as emissoras de rádio, de TV e os grandes portais da Internet são veículos da América Latina Oficial. No caso brasileiro, mídias como Folha de S.Paulo, 0 Estado de S. Paulo, O Globo, Jornal do Brasil, Veja, Isto É, Época, Jovem Pan, Bandeirantes, Rede Globo, TV Record, UOL e Terra.

A América Latina Popular, a custa de muito esforço de militantes e intelectuais engajados, também tem os seus veículos: Caros Amigos, Brasil de Fato, Agência Carta Maior, Adital, ALAI, Voz Rebelde, Rebeldia, Jornal Sem Terra, Revista Sem Terra, Correio da Cidadania, Revista Fórum, América Libre, Vozes da Terra entre outros. É a imprensa das classes subalternas, também chamada de imprensa proletária ou alternativa. Nas páginas dessa imprensa está registrada a história das lutas populares, as greves operárias, as revoluções no campo, as guerrilhas, os movimentos sociais, a cultura das classes subalternas. Se não fosse pela imprensa alternativa a história dos vencidos não seria contada.

A América Latina Oficial não vê a América Latina Popular como irmã. O preconceito do branco burguês ao mestiço proletário é o mesmo preconceito que o Ocidente nutre pelo Oriente. É um preconceito baseado menos na genética e mais nos diferentes graus de desenvolvimento. A história da América Latina é recheada de episódios de preconceito, principalmente quando as classes subalternas se revoltavam.

A repressão aos movimentos populares, da resistência indígena de Tupac Amaru, passando pelos quilombos negros até as guerrilhas de esquerda no século $\mathrm{XX}$ foi alimentada também pelo preconceito das elites, que não admitem que os "condenados da terra" tenham oportunidade de se manifestar e de lutar.

Essa repressão às lutas da América Latina Popular não foi feita apenas pela força das armas, mas também - e em várias oportunidades ao longo da história - pela força da mídia da América Latina Oficial. A grande imprensa especializou-se em denegrir a imagem dos movimentos sociais e, por extensão, dos meios de comunicação alternativos. Ora destruindo-os, como fazia a ditadura militar no Brasil, ora acusando-os de piratas, ora por 
pressões econômicas de anúncios e distribuição, a grande imprensa orquestra uma campanha para que estes veículos não frutifiquem.

A América Latina Popular não é retratada na grande imprensa, que só tem olhos para a América Latina Oficial - mesmo assim em momentos muito singulares. Apenas a imprensa alternativa tem a América Latina Popular nas suas categorias de seleção de notícia. Essa cisão entre as regiões e a imprensa já é um dos fatores que explica a hipótese. É uma luta de classes entre as duas regiões e as duas imprensas, tal qual uma guerrilha, em que a imprensa alternativa faz o papel do guerrilheiro.

Como em toda guerrilha, a luta não pode ser travada em iguais condições. O guerrilheiro deve se deslocar no terreno que mais conhece, se aliando à população local, atacando o inimigo rapidamente quando ele menos espera e nos seus pontos mais fracos. A imprensa das classes subalternas não pode disputar com a grande imprensa a inserção de anúncios publicitários, a circulação em grande escala e a venda em bancas. Essas são estratégias da grande imprensa. A guerrilha se estabelece quando a imprensa alternativa assume seu caráter político, a defesa explícita de uma ideologia, a intenção de falar para e sobre os excluídos e, conseqüentemente, quando realiza reportagens de qualidade editorial e gráfica.

O uso do termo guerrilha na comunicação não é exclusivo desta dissertação. Umberto Eco, em 1967, já a empregava:

"Por isso à solução de estratégia será preciso, amanhã, aplicar uma solução de guerrilha. É preciso ocupar, em todos os lugares do mundo, a primeira cadeira diante de cada aparelho de televisão (e naturalmente: a cadeira do líder de grupo diante de cada tela cinematográfica, de cada transmissor, de cada página de jornal). [...] a batalha pela sobrevivência do homem como ser responsável na Era da Comunicação não é vencida lá onde a comunicação parte, mas aonde ela chega. [...] nós teremos de ser capazes de imaginar sistemas de comunicação complementar que nos permitam atingir cada grupo humano isolado, cada membro isolado do público universal, para discutir a mensagem que chega à luz dos códigos de chegada, confrontando-os com os de partida." ${ }^{193}$

Nos estudos sobre a comunicação na América Latina, o primeiro esforço foi de provar a ausência do continente no noticiário da grande imprensa. Autores como José

${ }^{193}$ ECO, Umberto. Guerrilha Semiológica. In: Viagem na irrealidade cotidiana. Rio de Janeiro: Nova Fronteira, 1984. p 173. 
Marques de Melo e Maria Nazareth Ferreira merecem destaque por levar o tema para a Academia. Na seqüência, vieram outros trabalhos com a mesma finalidade. Todos, porém, fixavam a análise em uma área - ou no campo jornalístico ou no campo das Ciências Sociais. Esta dissertação cruzou análises das duas áreas.

Para demonstrar os processos que excluem definitivamente a América Latina popular das categorias de seleção da grande imprensa é preciso também apontar fatores como a influência capitalista no jornalismo (e mais recentemente a ideologia neoliberal), a americanização do Brasil, o preconceito da elite, a história da repressão aos movimentos sociais, os óculos adotados pelo jornalista, a relação de trabalho nas redações e o despreparo intelectual do jornalista.

Afirmar a influência do capitalismo no modo de produção jornalístico e reconhecer que a esquerda teve importância em processos decisivos na América Latina é dever de todo intelectual, para escapar da corrente que decreta o fim da História preconizada por Francis Fukuyama. Não há como decretar o fim dos confrontos, das oposições de classe e das lutas sociais. A comunicação da América Latina Popular deve cerrar fileiras ao lado dos movimentos populares latino-americanos e estabelecer uma guerra de guerrilhas contra a grande imprensa.

De fato, o jornalismo está ligado ao mercado, ao lucro. Onde há comércio, há jornalismo. Porém, só a influência capitalista não é suficiente para explicar os fatores que levam a grande imprensa a excluir a região do noticiário. Se assim fosse, mesmo as notícias sobre a Área de Livre Comércio das Américas (ALCA) ou sobre tratados do Mercosul teriam mais espaço do que recebem. Mesmo quando as notícias são ligadas à lógica capitalista, a América Latina continua a ser excluída.

O que faz um jornalista optar entre uma notícia e outra, além de diversas técnicas acumuladas no dia-a-dia do jornalismo, são categorias de pensamento - que Pierre Bourdieu batizou de óculos - que selecionam o que é interessante e o que não é interessante. Apesar da adoção do lead como modelo de jornalismo objetivo, a análise de alguns veículos e reportagens feita nesta dissertação mostra que a imparcialidade não 
existe. Cada veículo é um aparelho ideológico e, mesmo disfarçado no formato de jornalismo objetivo, a subjetividade tomar o lugar da objetividade. Portanto, o jornalista utiliza categorias na seleção e redação de notícias. Essas categorias, ou óculos, não enxergam a América Latina Popular.

A grande imprensa é orgânica da América Latina Oficial, burguesa, branca, elitista. Na grande imprensa a América Latina Popular tem uma imagem associada ao atraso, à corrupção, à pobreza. Essa construção negativa foi empreendida pelas elites latinoamericanas, aliadas às burguesias européias e norte-americanas, não só nos veículos de comunicação, mas também nos livros de História e nos processos de ensino.

A elite - público-alvo da grande imprensa - não se interessa pela América Latina Popular incluindo nesse desprezo a periferia das grandes cidades. O processo é o mesmo. Quando uma jovem estudante de um colégio particular e tradicional de São Paulo, integrante da elite branca, é assassinada, os holofotes da mídia se voltam para o fato e o repercutem à exaustão. Porém, quando o assassinato é cometido contra um jovem da periferia, ele não ganha a capa das revistas semanais, nem manchetes nos telejornais. Da mesma forma acontece com a América Latina. Um novo tipo de lanche consumido nos restaurantes norte-americanos tem preferência contra notícias do mesmo tipo, mas originadas nos países latino-americanos.

Saber da moda norte-americana, do que as rádios norte-americanas estão tocando, quais são os filmes produzidos por Hollywood, entre outros fatos, transmite ao receptor a proximidade com os EUA. Da mesma forma, as notícias da periferia entram no noticiário na forma de catástrofes ou de culto ao exotismo, apenas para justificar a distância entre ela, periferia, e o centro do mundo e para transmitir a sensação definitiva de que o público não pertence a essa periferia, seja ela a periferia da cidade ou a periferia do mundo.

Entre as razões para a utilização de tanto material norte-americano e de haver sempre correspondentes brasileiros em Nova lorque está o fato de que o jornalismo brasileiro foi se desenvolvendo ao mesmo tempo em que se processava a americanização brasileira na Segunda Guerra Mundial. Esta dissertação procurou demonstrar como o Brasil 
era visto como um importante aliado para deter o avanço nazista no Atlântico Sul, para ganhar a simpatia do governo e da população brasileira à causa de guerra norte-americana, foi feito um intenso processo de aproximação do país com os EUA. Esse processo foi feito pelos meios de comunicação, pelo cinema, pelas revistas e, principalmente pelo rádio. Assim, enquanto o jornalismo brasileiro deixava de ser apenas uma manifestação política como era no século XIX - e passava a ser uma empresa capitalista, o modo de produção jornalístico dos EUA era descarregado a todo o momento por programas de rádio e revistas. Os jornalistas brasileiros foram se formando sob a "cartilha" do jornalismo norte-americano. Daí a grande semelhança entre o jornalismo dos dois países.

Soma-se a todo este cenário, o processo de exploração dos jornalistas nas redações. Os profissionais de comunicação são submetidos a cobrir uma grande quantidade de pautas e são obrigados, pela concorrência capitalista entre os veículos de comunicação, a conseguir sempre a notícia com exclusividade em primeiro lugar - é o chamado "furo jornalístico", o que diminui a possibilidade de apuração das notícias. Pelas novas características do jornalismo essa busca pelo furo foi acrescentada da ideologia da "notícia em tempo real", elevando ainda mais a exploração do jornalista. Os novos repórteres são colocados em situações extremas, como cobrir enchentes com água pela cintura, narrando situações dramáticas.

A exclusão também é decorrente dos processos de ensino-aprendizagem. Os jornalistas não conhecem a América Latina profundamente. Os nomes de grandes figuras históricas são desconhecidos. A história dos países é desconhecida. Não se ensina América Latina nem na educação básica e muito menos na educação superior. Portanto, além de não usarem categorias que "enxerguem" a América Latina, os jornalistas ignoram intelectualmente o que ela é.

Na linha marxista de análise histórica, não basta entender os processos - é preciso mudá-los. As propostas de alteração deste cenário de solidão passam pelo desenvolvimento dos movimentos sociais latino-americanos e pela inclusão de outra história latino-americana 
- a história dos movimentos sociais - nas grades curriculares do ensino básico e do superior.

A América Latina popular precisa ter voz. É muito importante que os movimentos populares tenham seus próprios meios de comunicação; vários já os têm. O MST tem seu próprio site, jornal, revista e uma rádio, mas essa é uma ação que deve passar também pelos governos e pelas políticas de cada nação latino-americana, que devem se firmar como países soberanos e que possam se unir e cooperar na solução de problemas comuns a todos: erradicação da fome e da pobreza, implantação da reforma agrária, desenvolvimento industrial sustentável, preservação da fauna, da flora e dos recursos minerais, a eliminação da corrupção, o fortalecimento das culturas, a preservação dos folclores e afirmação de políticas nacionais que não se submetam às intervenções norte-americanas.

A ação também passa pelo desenvolvimento de mais intelectuais orgânicos da América Latina Popular. Intelectuais (professores, estudantes, jornalistas, cientistas, sociólogos, etc) que analisem os problemas da América Latina e pensem em soluções para ela. O desenvolvimento do intelectual orgânico passa pelo fortalecimento da sociedade civil da América Latina Popular, que só só ocorre quando se investe em educação. Entenda-se por "investimento" não só o governamental, mas a criação de novas políticas educacionais que tenham por objetivo fortalecer a região.

Essas novas políticas podem começar incluindo componentes da América Latina nas grades curriculares dos cursos de Educação Básica (ensinos fundamental e médio) e de Educação Superior (principalmente nos de Comunicação Social). Essa educação sobre a América Latina deve não só reconstruir a história do continente, mas tirar da sombra ações e discursos que foram esquecidos. Deve reescrever a história não só pela versão dos vencedores, mas também pela dos vencidos, e, principalmente, deve debater questões e propor soluções que contemplem as necessidades políticas apontadas.

Esta dissertação de mestrado abre a possibilidade de novos estudos a partir desta conclusão e que podem ser desenvolvidos no doutorado. Entre os caminhos abertos estão a investigação sobre a construção da imagem da América Latina nos livros de história, a 
investigação de como se deu Reforma Universitária de Córdoba e se seria necessária uma reforma semelhante no Brasil para incluir a América Latina definitivamente nas categorias de seleção de notícia. Outro caminho, que pode ser trilhado no doutorado, é estruturar um processo de educação de jornalistas para a formatação de óculos que contemplem também a América Latina, em especial a América Latina Popular.

Os resultados colhidos em apenas quatro meses de aula com uma turma do primeiro ano do curso de Jornalismo de uma faculdade privada da capital paulista, em que os estudantes foram incentivados a ter outro olhar para a história e, em resposta, propuseram a criação de uma nova mídia que tem esse novo olhar, é uma pista de como um trabalho maior pode contribuir mais para a retirada da América Latina dessa condenação à solidão.

\section{Cantata Santa María de Iquique}

\section{Canción final - Luis Advis}

Ustedes que ya escucharon la historia que se contó no sigan alli sentados pensando que ya pasó. No basta solo el recuerdo, ya no basta con llorar. No es tiempo de lamentarse, cuando es tiempo de luchar. Quizás mañana o pasado o bien, en un tiempo más, la historia que han escuchado de nuevo sucederá.

[...]

Tenemos razones puras, tenemos por qué pelear. Tenemos las manos duras, tenemos con qué ganar. Unámonos como hermanos que nadie nos vencerá. Si quieren esclavizarnos jamás lo podrán lograr. La tierra será de todos también será nuestro el mar. Justicia habrá para todos y habrá también libertad. Luchemos por los derechos que todos deben tener.

Luchemos por lo que es nuestro, de nadie mas ha de ser. 


\section{REFERÊNCIAS BIBLIOGRÁFICAS}

ABRAMO, Bia. (Org.) Um trabalhador da notícia: textos de Perseu Abramo.

São Paulo: Fundação Perseu Abramo, 1997.

ALVES, Júlia Falivene. A invasão cultural norte-americana. São Paulo: Moderna, 1988.

ANDERSON, Jon Lee. Che - uma biografia. Rio de Janeiro: Objetiva, 1997.

ARBEX JR., José. Guerra Fria: terror de Estado, política e cultura. São Paulo: Moderna, 1997.

Showrnalismo: a notícia como espetáculo. São Paulo: Casa Amarela, 2001.

\& SENISE, Maria Helena Valente. Cinco séculos de Brasil, imagens e visões.

São Paulo: Moderna, 1998.

BARBOSA, Alexandre. A luta de classes entre a mídia oficial e a alternativa na América

Latina: buscando fissuras nos muros do pensamento único. São Paulo, 2000. Tese de Conclusão de Curso de Pós-Graduação Lato Sensu em Jornalismo Internacional. Pontifícia Universidade Católica de São Paulo - PUC-SP.

BETTO, Frei \& SADER, Emir. Contraversões: civilização ou barbárie na virada do século. São Paulo: Boitempo, 2000.

BOBBIO, Noberto; MATTEUCI, Nicola; PASQUINO, Gianfranco. Dicionário de política, v. 2. 5. ed. Brasília: Universidade de Brasília, 2000.

BOLETIM MUNDO - Geografia e Política Internacional. Edições 1-61 (1992 a 2002).

CD-Rom. São Paulo: Pangea/Ediouro, 2004.

BORN, Margarethe Steinberger-Elias. Discursos geopolíticos da mídia: jornalismo e imaginário internacional na América Latina. São Paulo: Cortez, 2005.

BOURDIEU, Pierre. Sobre a televisão. Seguido de A influência do jornalismo e Os Jogos Olímpicos. Trad. Maria Lúcia Machado. Rio de Janeiro: Jorge Zahar, 1997.

BRASIL DE FATO. Edições 1-50 (2003 a 2004). 
BUCCl, Eugênio. (Org.) A TV aos 50: criticando a televisão brasileira no seu cinqüentenário. São Paulo: Fundação Perseu Abramo, 2000.

CANCLINI, Néstor García. Culturas híbridas. São Paulo: Edusp, 1997. (Ensaios LatinoAmericanos, 1).

. Latinoamericanos buscando lugar en este siglo. Buenos Aires: Paidós, 2002.

CARR, Edward Hallet. Que é História? 6. ed. Rio de Janeiro: Paz e Terra, 1989.

CERTEAU, Michel de. A escrita da História. Rio de Janeiro: Forense Universitária, 2002.

CHIAVENATO, Júlio José. As lutas do povo brasileiro. 15. ed. São Paulo: Moderna, 1996.

COMAS, Juan. Os mitos raciais. In: Raça e ciência. São Paulo: Perspectiva/Unesco. [s.d.].

COUTINHO, Carlos Nélson. Os intelectuais e a organização da cultura. Rio de Janeiro: AUPHIB, 1980.

\& NOGUEIRA, Marco Aurélio. (Orgs.) Gramsci e a América Latina. Rio de Janeiro: Paz e Terra, 1993.

DEBRAY, Régis. O Estado sedutor: as revoluções midiológicas do poder. Petrópolis: Vozes, 1994.

DI FELICE, Mássimo \& MUÑOZ, Cristobal. A revolução invencível: Subcomandante Marcos e Exército Zapatista de Libertação Nacional. Cartas e comunicados. São Paulo: Boitempo, 1998.

DONGHI, Túlio Halperin. História da América Latina. Rio de Janeiro: Paz e Terra, 1975.

DOWBOR, Ladislau; IANNI, Octavio; Resende, Paulo-Edgar A. (Org.) Desafios da globalização. Rio de Janeiro: Vozes, 1997.

DREIFUSS, René Armand. 1964 - a conquista do Estado: ação política, poder e golpe de classe. Petrópolis, Rio de Janeiro: Vozes, 1981.

ECO, Umberto. Viagem na irrealidade cotidiana. Rio de Janeiro: Nova Fronteira, 1984.

EDITORA ABRIL. Manual de Estilo da Editora Abril: como escrever bem para nossas revistas. 13. ed. Rio de Janeiro: Nova Fronteira, 1990.

FANON, Frantz. Os condenados da terra. 2. ed. Rio de Janeiro: Civilização Brasileira, 1979. 
FERRARI, Pollyana. Jornalismo digital. São Paulo: Contexto, 2004.

FERREIRA, Maria Nazareth. A comunicação (des)integradora na América Latina: os contrastes do neoliberalismo. São Paulo: Edicon/Cebela, 1995.

(Org). América Latina, a imagem de um continente na escola e nos meios de comunicação. São Paulo: CELACC/ECA, 1997.

Comunicação e resistência na imprensa proletária. Tese de Livre-docência na Especialidade Cultura Brasileira. São Paulo, 1990. Escola de Comunicação e Artes (ECA) - Universidade de São Paulo.

. (Org). Cultura, comunicação e movimentos sociais. São Paulo:

CELACC:ECA, 1999.

Globalização e identidade cultural na América Latina: a cultura subalterna frente ao neoliberalismo. São Paulo: CEBELA, 1995.

FOLHA DE S.PAULO - edições de 1998 a 2002.

FREIRE, Alípio et alli. Tiradentes, um presídio da ditadura: memórias de presos políticos. São Paulo: Scipione, 1997.

GALEANO, Eduardo. As veias abertas da América Latina. Petrópolis: Paz e Terra, 1982. Memória de fogo: o século do vento. As dimensões e os segredos da América Latina num mosaico de histórias, fatos, mitos e homens, v. III. Porto Alegre: L\&PM, 1998.

GENRO FILHO, Adelmo. O segredo da pirâmide: para uma teoria marxista do jornalismo. Porto Alegre: Tchê, 1987.

GORENDER, Jacob. Combate nas trevas: das ilusões perdidas à luta armada. 5. ed. São Paulo: Ática, 1998.

GRAMSCI, Antônio. Maquiavel, a política e o Estado moderno. Rio de Janeiro: Civilização, 1991.

Os intelectuais e a organização da cultura. Rio de Janeiro: Civilização, 1968.

GUARESCHI, Pedrinho A. (Org.) Comunicação e controle social. Petrópolis: Vozes, 1991. HARNECKER, Marta. Tornar possível o impossível. Rio de Janeiro: Paz e Terra, 2000. HELLER, Agnes. O cotidiano e a história. 6. ed. São Paulo: Paz e Terra, 2000. 
HOBSBAWN, Eric. $\boldsymbol{A}$ era dos extremos: o breve século XX (1914-1991). São Paulo: Cia. das Letras, 1995.

HUGGINS, Martha K. Polícia e política: relações EUA-América Latina. São Paulo: Cortez, 1998.

IANNI, Octavio. O labirinto latino-americano. Petrópolis, Rio de Janeiro: Vozes, 1993.

JARA, Joan. Canção inacabada. Rio de Janeiro: Record, 1998.

JORNAL SEM TERRA. Edições de 2000 a 2003.

JOSÉ, Emiliano. Carlos Marighella: o inimigo número um da ditadura militar. São Paulo: Sol \& Chuva, 1997.

KUSHNIR, Beatriz. Cães de guarda: jornalistas e censores do AI-5 à Constituição de 1988. São Paulo: Boitempo, 2004.

KUCINSKY, Bernardo. Jornalistas e revolucionários: nos tempos da imprensa alternativa. São Paulo: Scritta, 1991.

LAURENZA, Ana Maria de Abreu. Lacerda X Wainer. o corvo e o bessarabiano. São Paulo: Senac, 1998.

LEITE, Dante Moreira. As raízes do caráter nacional. In: O caráter nacional brasileiro. São Paulo: Ática, [s.d.].

LESSA, Carlos. O Rio de todos os Brasis. Rio de Janeiro: Record, 2000.

LOPES, Marcelo José Abreu. Olhares sobre o mundo: valores na notícia da integração regional. São Paulo, 2001. Dissertação de Mestrado. Programa de Pós-Graduação em Comunicação. Universidade de São Paulo - USP.

LÖWY, Michael. (Org.) 0 marxismo na América Latina. São Paulo: Fundação Perseu Abramo, 1999.

LUDMER, Josefina. Cem anos de solidão: uma interpretação. Trad. Antonio de Pádua Danesi. São Paulo: Martins Fontes, 1989.

MARCONDES FILHO, Ciro. Quem manipula quem?: poder e massas na indústria da cultura e da comunicação no Brasil. Petrópolis: Vozes, 1986.

Jornalismo Fin-de-siécle. São Paulo: Scritta Editorial, 1993. 
MARINI, Ruy Mauro \& MILLÁN, Márgara. (Org.) La Teoría Social Latinoamericana: textos escogidos. Tomo II. México: Universidad Nacional Autonoma de México, [s.d.].

MARIÁTEGUI, José Carlos. La Unidad Latinoamericana. In: MARINI, Ruy Mauro \& MILLÁN, Márgara. (Org.) La Teoría Social Latinoamericana: textos escogidos. Tomo I. México: Universidad Nacional Autonoma de México, [s.d.].

[1924] Textos básicos. Lima, Perú: Fondo de Cultura Económica, 1991.

MÁRQUEZ, Gabriel García. Cem anos de solidão. Rio de Janeiro: Record, 1999.

La Soledad de América Latina: Escritos sobre arte y literatura, 1948-1984. La Habana, Cuba: Arte Y Literatura, 1990.

MARTÍN-BARBERO, Jesús. [1987] Dos meios às mediações: comunicação, cultura e hegemonia. 2. ed. Trad. Ronald Polito e Sérgio Alcides. Rio de Janeiro: UFRJ, 2003.

MARTINS, Eduardo. Manual de redação e estilo de O Estado de S. Paulo. 3. ed. São Paulo: O Estado de S. Paulo, 1997.

MARX, Karl \& ENGELS, Friedrich. Manifesto do partido comunista. 8. ed. São Paulo: Global, 1988. (Universidade Popular).

MELO, José Marques de. Comunicação: teoria e política. São Paulo: Summus, 1985.

MEMMI, Albert. O retrato do colonizado precedido pelo retrato do colonizador. 3 . ed. São Paulo: Paz e Terra, 1989.

NATALI, João Batista. Jornalismo internacional. São Paulo: Contexto, 2004.

NERUDA, Pablo. Canto geral. São Paulo: Difusão Editorial, 1980.

O ESTADO DE S. PAULO - Edições de 1998 a 2000.

OLIVEIRA, Francisco. Crítica à razão dualista/ o ornitorrinco. São Paulo: Boitempo, 2003. PAZ, Octávio. O labirinto da solidão e post scriptum. Trad. Eliane Zagury. Rio de Janeiro: Paz e Terra, 1984.

PERICÁS, Luiz Bernardo \& BARSOTTI, Paulo. (Orgs.) América Latina: história, crise e movimento. São Paulo: Xamã, 1999.

PETRAS, James. Armadilha neoliberal. E alternativas para a América Latina. São Paulo: Xamã, 1999. 
RAMONET, Ignacio. A tirania da comunicação. Trad. Lúcia Mathilde Endlich Orth. Petrópolis, Rio de Janeiro: Vozes, 1999.

REIS FILHO, Daniel Aaarão et alli. Versões e ficções: o seqüestro da história. São Paulo: Perseu Abramo, 1997.

RIBEIRO, Ana Paula Goulart. Jornalismo, literatura e política: a modernização da imprensa carioca nos anos 1950. Estudos Históricos, Mídia, n. 31, Rio de Janeiro: CPDOC/FGV, 2003.

RIBEIRO, Darcy. América Latina: a pátria grande. Rio de Janeiro: Guanabara, 1986. et alii. $\boldsymbol{A}$ sagração da liberdade: heróis e mártires da América Latina. Rio de Janeiro: Revan, 1994.

SADER, Emir. Cartas a Che Guevara: o mundo trinta anos depois. São Paulo: Paz e Terra, 1997.

Cuba, Chile e Nicarágua: socialismo na América Latina. São Paulo: Atual, 1992. Século XX: uma biografia não autorizada. O século do Imperialismo. São Paulo: Fundação Perseu Abramo, 2000.

Sem perder a ternura. Rio de Janeiro: Record, 1999.

O Mundo Pelo Avesso. Disponível em www.agenciacartamaior.com.br. Acesso em 26 jun 05.

SAINT-PIERRE, Héctor Luis. A política armada: fundamentos da guerra revolucionária. São Paulo: Unesp, 2000.

SANTOS, Milton. Território e sociedade: entrevista a Odette Seabra, Mônica de Carvalho e José Corrêa Leite. São Paulo: Fundação Perseu Abramo, 2000.

SARAMAGO, José. Levantado do chão. Rio de Janeiro: Record/Altaya, 1996.

SARLO, Beatriz. Cenas da vida pós-moderna. Rio de Janeiro: UFRJ, 1997.

SCHÜRMANN, Francisca Albertina. Sindicalismo e democracia: os casos do Brasil e do Chile. Brasil: Universidade de Brasília, 1998.

SOBRINHO, José Coelho. O Brasil está de costas para a América Latina. ABECOM, 1994. 
SODRÉ, Nelson Werneck. História da imprensa no Brasil. 4. ed. Rio de Janeiro: Mauad, 1999.

THOMPSON, John B. [1995] Ideologia e cultura moderna: teoria social crítica na era dos meios de comunicação de massa. 6. ed. Petrópolis, Rio de Janeiro: Vozes, 2002.

TOTA, Antonio Pedro. O imperialismo sedutor. São Paulo: Companhia das Letras, 2000.

VÉLEZ, Manuel Marulhada. Esboço histórico das FARC-EP. Comissão Internacional das FARC-EP, 1998.

VICENTINI, Paulo Fagundes. Relações internacionais do Brasil: de Vargas a Lula. São Paulo: Fundação Perseu Abramo, 2003.

\section{DEPOIMENTOS}

Heródoto Barbeiro, editor chefe da Rádio CBN. Janeiro 2003.

Igor Fuser, jornalista da editoria de internacional da Revista Época. Março 2003.

José Arbex Jr., diretor do jornal Brasil de Fato. Março 2003.

José Sacchetta Ramos e Simone Biehler Mateos, editores da revista Atenção! 1996.

Luis Mota, apresentador do programa De Olho no Mundo - Rádio Eldorado. Março 2003.

Natalia Ferreira de Campos, aluna do primeiro ano de jornalismo do Centro Universitário Nove de Julho. Maio 2005.

Paulo Sérgio Pinheiro, presidente do Núcleo de Estudos da Violência da USP (NEV/USP) 1999.

Vicente Adorno, editor de Internacional da TV Cultura. Fevereiro 2002.

\section{REVISTAS}

REVISTA ATENÇÃO! - Edições 1-9 (1996)

REVISTA ÉPOCA - Edições 29 (3/12/1998) e 43 (15/3/1999)

REVISTA RESISTÊNCIA - Edição 32 (maio de 2004)

REVISTA SEM TERRA - Edições 1-21 (1999 a 2003) 
REVISTA VEJA - Edições 1648, 1899 e 1903 (2000 a 2005)

\section{SITES}

AGENCE FRANCE-PRESSE. <www.afp.com>. Acesso em: 15 jun 2004.

AGÊNCIA CARTA MAIOR. <www.agenciacartamaior.com.br>. Acesso em: 15 jun 2004.

AGÊNCIA DE INFORMAÇÃO FREI TITO PARA A AMÉRICA LATINA.

<www.adital.org.br>. Acesso em: 3 jun 2004.

AGENCIA LATINOAMERICANA DE INFORMACIÓN - ALAI. <www.alainet.org>. Acesso em: 8 abr 2005.

ANSA. <www.ansa.it>. Acesso em: 15 jun 2004.

ASSOCIATED PRESS. <www.ap.org>. Acesso em: 15 jun 2004.

COMUNISMO. <www.comunismo.com.br>. Acesso em: 8 out 2003.

EFE. <www.efe.es>. Acesso em: 15 jun 2004.

PLANETA PORTO ALEGRE. <www.portoalegre2003.org>. Acesso em: 23 jul 2004.

REUTERS. <www.reuters.com>. Acesso em: 15 jun 2004.

TROVADORES. <www.trovadores.net>. Acesso em: 20 jul 2004.

UNITED PRESS INTERNATIONAL. <www.upi.com>. Acesso em: 15 jun 2004.

\section{VÍDEOS}

JANELA DA ALMA. Dir. João Jardim e Walter Carvalho. Brasil, Copacabana Filmes, $73 \mathrm{~min}, 2002$.

UMA LUTA DE TODOS. Oficina de Linguagem Audiovisual FILO/MST. Criação e produção coletiva. 27 min. VHS. NTSC. Maio de 2000. 


\section{ANEXOS}

\section{Anexo 1}

Roteiro do Questionário Aberto aplicado aos jornalistas Heródoto Barbeiro, José Arbex Jr, Vicente Adorno, Igor Fuser e Luis Mota.

1 - O Sr. considera que o jornalismo reflete o que acontece na sociedade?

2 - Podemos considerar o jornalismo um espelho da sociedade?

3 - Quais são os acontecimentos de maior destaque nos últimos meses? Apontar.

4 - Para entender esses acontecimentos não é necessário entender o passado e comparar o que mudou?

5 - Se o jornalismo reflete o que se passa na sociedade, a América Latina tem seu reflexo no jornalismo brasileiro?

6 - Diariamente há alguma notícia da América Latina na grade de jornalismo desta empresa?

7 - Qual a porcentagem de notícias da América Latina em relação a notícias de outras regiões do mundo?

8 - Que tipo de notícias da América Latina são publicadas?

9 - Quantos correspondentes a empresa tem em países da América Latina?

10 - Os ouvintes/leitores do jornalismo desta empresa têm interesse em notícias da América Latina? Por que?

11 - A falta de verbas justifica dar mais espaço para notícias do eixo EUA/Europa do que notícias sobre América Latina?

12 - Por que, mesmo com o Mercosul e a Globalização, a América Latina não tem espaço?

13 - Quais as causas do preconceito em relação à América Latina?

14 - O jornalista tem o dever de quebrar esse preconceito?

15 - O jornalista está preparado para quebrar esse preconceito?

16 - Um das maneiras de quebrar o preconceito seria a preparação acadêmica do jornalista?

17 - A inclusão de uma disciplina sobre História da América Latina na grade curricular dos cursos de jornalismo seria útil nesse processo de desmonte de narrativas.

18 - Quais os conteúdos mais importantes a serem colocados nesta disciplina? 
E nascerá de novo esta palavra, talvez em outro tempo sem dores, sem as impuras fibras que aderiram negras vegetações em meu canto, e outra vez nas alturas estará ardendo meu coração queimante e estrelado. assim termina este livro, aqui deixo meu Canto geral escrito na perseguição, cantando sob as asas clandestinas de minha pátria.

Pablo Neruda. Última estrofe de $\mathbf{O}$ Canto Geral. 